SANDRA PIRES DE TOLEDO PEDROSO

\title{
O tempo da Utopia
}

Versão corrigida

(Versão original encontra-se na unidade que aloja o Programa de Pós-graduação)

Tese apresentada ao Programa de Pós-Graduação do Departamento de Filosofia da Faculdade de Filosofia, Letras e Ciências Humanas da Universidade de São Paulo como parte das exigências para a obtenção do título de Doutora em Filosofia.

Orientadora: Prof ${ }^{a}$ Dr $^{\mathrm{a}}$ Maria das Graças de Souza 
Autorizo a reprodução e divulgação total ou parcial deste trabalho, por qualquer meio convencional ou eletrônico, para fins de estudo e pesquisa, desde que citada a fonte.

Catalogação na Publicação

Serviço de Biblioteca e Documentação

Faculdade de Filosofia, Letras e Ciências Humanas da Universidade de São Paulo

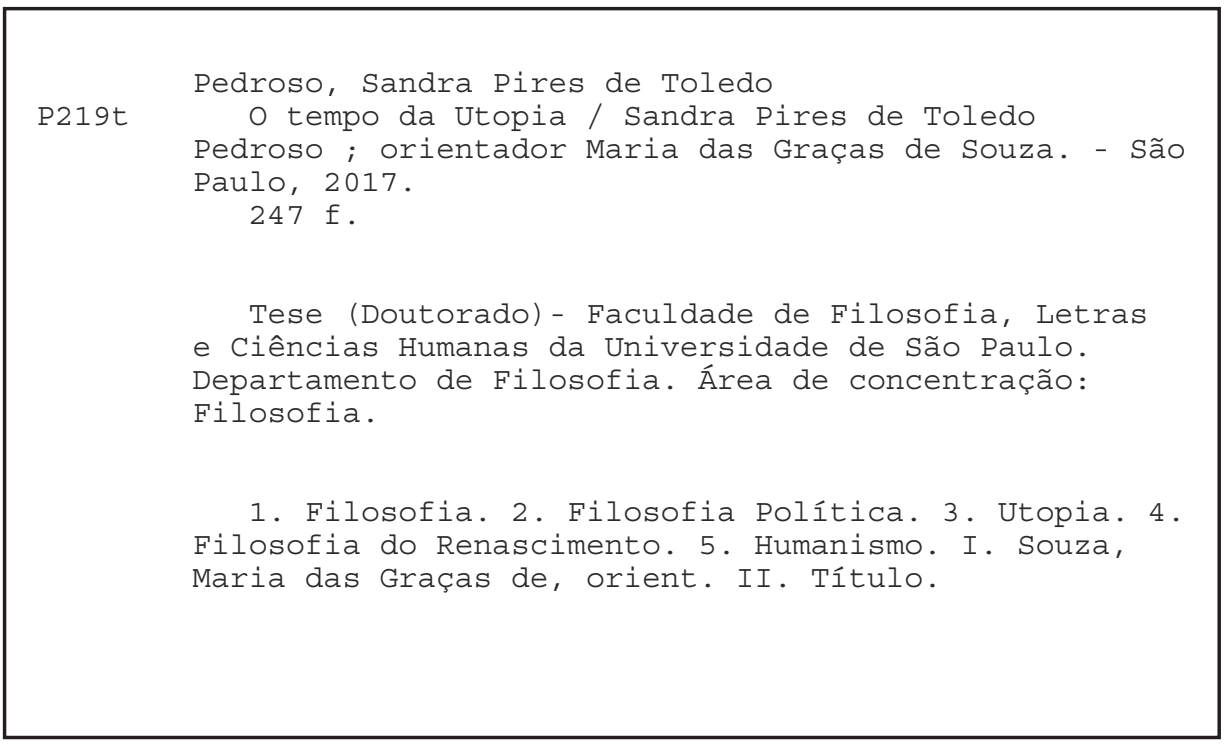




\section{FOLHA DE APROVAÇÃO}

Sandra Pires de Toledo Pedroso

O Tempo da Utopia

Tese apresentada ao Programa de PósGraduação do Departamento de Filosofia da Faculdade de Filosofia, Letras e Ciências Humanas da Universidade de São Paulo, como parte dos pré-requisitos para a obtenção do título de doutora.

Área de concentração: Filosofia

Aprovado em:

Banca Examinadora

Prof. Dr.:

Instituição:

Assinatura:

Prof. Dr.:

Instituição:

Assinatura:

Prof. Dr.:

Instituição:

Assinatura:

Prof. Dr.:

Instituição:

Assinatura:

Prof. Dr.:

Instituição: Assinatura: 
À Maria das Graças,

ao meu esposo Gustavo

e a todos aqueles que contra toda a lógica ainda riem e sonham. 


\section{AGRADECIMENTOS}

Todos aqueles que de uma forma ou de outra contribuíram para que eu chegasse até aqui têm a minha sincera gratidão.

Mas é sobretudo à minha orientadora, Prof ${ }^{a}$. Maria das Graças de Souza, que acolheu com simpatia e carinho a ideia de uma pesquisa sobre Utopia e me tratou durante todo o período com a generosidade e a preocupação que lhe são peculiares. É a ela também que devo o primeiro contato com o tema num curso de graduação no ano de 2002. Sem dúvida, merece toda a minha gratidão e o meu respeito. Agradeço à Prof ${ }^{\mathrm{a}}$. Patrícia Fontoura Aranovich e ao Prof. Alberto Ribeiro Gonçalves de Barros pelas valiosas sugestões na minha banca de qualificação.

Agradeço também aos amigos do Grupo de Estudos Res publica pelo período que passamos juntos, pelas tardes de estudo sérias e prazerosas, uma experiência gratificante e fundamental para a minha formação. Não posso deixar de mencionar o período que passei nos Cadernos de Ética e Filosofia Política, onde encontrei pessoas sérias e dedicadas, mas também amigos fraternos e solidários.

Devo muito do que sou aos professores do Departamento de Filosofia da USP, a eles toda a minha gratidão e meu respeito. Ainda me lembro com carinho e saudades das aulas que se prolongavam nas discussões nos corredores da faculdade e do Crusp.

Sou grata também aos professores e estudantes da UNESP/Franca, cuja amizade, 
convivência e apoio suavizaram as dificuldades do processo de adaptação numa cidade tão diferente e tão distante de tudo o que eu conhecia.

Gostaria ainda de expressar minha gratidão por minha família. Em primeiro lugar às mulheres ternas e fortes que me servem de modelo até hoje, mulheres para as quais a fortuna não poupou dificuldades, mas que sempre responderam com esforços: Minha avó, Maria Ferreira da Silva e minha mãe, Mirian da Silva Pires. À minha mãe também devo um imenso amor e apoio antes e durante este trabalho. À minha irmã Cibélia, amiga e companheira na luta pela vida, vida que, por vezes, nos tem colocado desafios que parecem intransponíveis. Não posso esquecer também do meu avô, José Venâncio da Silva, que com sua sabedoria rústica contava causos e antigas histórias dos heróis de Canudos, que eu distraidamente escutava, mas que fez nascer em mim a admiração por histórias dos tempos dos velhos, enquanto formava meu julgamento. A meu pai, Wilson Pires, que, além de toda a sua dedicação, e apesar de seu trabalho estafante, sempre reservava um pouco do seu tempo para contar aos filhos estórias de contos de fadas, nas quais fazia-nos crer que esteve presente. A ele devo minha capacidade de imaginar.

E, finalmente, ao meu amado esposo e companheiro de todas as horas, Gustavo Pedroso, por seu amor, por sua paciência sem limites, por sua sensibilidade, por todos estes felizes anos, pela filosofia e tantas outras coisas, e por ter me emprestado seus olhos para que eu também pudesse ver.

E, claro, a Thomas More por ter escrito a Utopia. 
O filosofar, desde a Antiguidade, tem acontecido na forma de fragmentos, poemas, diálogos, cartas, ensaios, confissões, meditações, paródias, peripatéticos passeios, acompanhados de infindável comentário, sempre recomeçado, e até os modelos mais clássicos de sistema (Espinosa com sua ética, Hegel com sua lógica, Fichte com sua doutrina-da-ciência) são atingidos nesse próprio estatuto sistemático pelo paradoxo constitutivo que nos faz viver.

Rubens Rodrigues Torres Filho

Um mapa-múndi que não inclua a Utopia não é digno de consulta, pois deixa de fora as terras à que a Humanidade está sempre aportando. E nelas aportando, olha adiante e, se divisa terras melhores, torna a içar velas. O progresso é a concretização de Utopias.

Oscar Wilde 


\section{RESUMO}

PEDROSO, S. P. T. O Tempo da Utopia. 2017. Tese (Doutorado) - Faculdade de Filosofia, Letras e Ciências Humanas, Universidade de São Paulo, São Paulo, 2017

A tese visa compreender a Utopia como uma obra política moderna de caráter literário e filosófico. A abordagem do aspecto literário é feita no primeiro capítulo e retomada no final, e busca em, primeiro lugar, estabelecer as diferenças fundamentais entre a Utopia e alguns dos constructos ideais que a precederam e com os quais ela é recorrentemente identificada, tais como a Era de Ouro, o paraíso e a Atlântida; em segundo lugar, ela procura também verificar a proximidade e a distancia da Utopia em relação à sátira, gênero literário com o qual a obra passou a ser identificado mais recentemente por uma parcela dos comentadores, mudando-se o seu registro do apologético para o crítico. $\mathrm{O}$ aspecto filosófico é tratado no segundo e no terceiro capítulos. No segundo se procura mapear as relações da Utopia com a filosofia política clássica, sobretudo no que respeita aos constructos filosóficos ideais, enquanto que o capítulo três discute a vinculação da Utopia com o humanismo erasmiano, do qual ela é, ao mesmo tempo, devedora e crítica. O quarto capítulo apresenta as considerações finais, procurando caracterizar a obra como um produto do renascimento inglês, produto este que combina literatura e filosofia de uma maneira singular, ambas se mesclando para compor o sentido político da obra, ambas com igual direito de cidadania em Utopia.

Palavras-chave: Utopia, Thomas More, erasmianismo, Renascimento Inglês. 


\begin{abstract}
PEDROSO, S. P. T. The Time of Utopia. 2017. Thesis (Doctoral) - Faculdade de Filosofia, Letras e Ciências Humanas, Universidade de São Paulo, São Paulo, 2017.

The thesis aims to understand Utopia as a modern political work of literary and philosophical character. The approach to the literary aspect is made in the first chapter and resumed at the end, and seeks first to establish the fundamental differences between Utopia and some of the ideal constructs that preceded it and with which it is recurrently identified, such as Age Of Gold, paradise and Atlantis; secondly, it also seeks to verify the proximity and distance of Utopia in relation to satire, a literary genre with which the work has been identified more recently by a portion of the commentators. The philosophical aspect is dealt with in the second and third chapters. In the second, we try to map the relations of Utopia with classical political philosophy, especially with regard to ideal philosophical constructs, while chapter three discusses the connection of Utopia with Erasmian humanism, of which it is at once debtor and critical. The fourth chapter presents the final considerations, seeking to characterize the Utopia as a product of the English Renaissance, a product that combines literature and philosophy in a unique way, both merging to compose the political sense of the work, both with equal citizenship rights in Utopia.
\end{abstract}

Keywords: Thomas More, Utopia, erasmianism, English Renaissance 


\section{SUMÁRIO}

$\begin{array}{ll}\text { Introdução } & 11\end{array}$

1 - Utopia, Eutopia: a vida feliz como imagem poética 18

2 - Filosofia e utopia: a cidade ideal como discurso filosófico 74

3 - Nusquama Nostra: a Utopia como obra humanista 154

4 - Considerações Finais: Forma e Política na Utopia de More 206

$\begin{array}{ll}\text { Bibliografia } & 238\end{array}$ 


\section{Introdução}

A obra mais famosa de More, A Utopia, foi publicada em 1516 e desde seu aparecimento até hoje foi objeto de inúmeros comentários, críticas e interpretações.

George Logan começa o seu livro The Meaning of More's "Utopia" caracterizando Utopia como um livro deliberadamente enigmático. Apesar de ter sido primariamente destinado a um público seleto, os chamados humanistas do Norte, os quais supostamente possuiriam a chave para desvendá-lo ${ }^{1}$, o fato é que mesmo entre estes primeiros leitores as dificuldades se mostram em alguns desencontros que abrem a longa cadeia de diversas significações atribuídas à Utopia ao longo de cinco séculos de tentativas de decifração.

Logan chama a atenção para a carta de Guillaume Budé, o qual recomenda a leitura do livro apontando a harmonia entre algumas práticas utopianas e "os costumes e a verdadeira sabedoria da cristandade" e deduz disto que Utopia é Hagiópolis, a Cidade Santa. Mas esta interpretação passa por alto o fato de que dificilmente determinadas instituições de Utopia se coadunariam inteiramente com os dogmas cristãos, sendo

\footnotetext{
${ }^{1}$ A expressão "humanistas do Norte" é utilizada na acepção dada por Quentin Skinner em As fundações do pensamento político moderno, nota 5 da pg. 635, a saber, um termo genérico e curto que se refere aos renascentistas dos países ao norte da Itália (Alemanha, França, Inglaterra, Países Baixos, etc.), que, a despeito das suas diferenças, possuem semelhanças culturais (filosóficas, sociais e políticas) suficientes, para justificar a identificação. O termo, segundo Skinner, serve para indicar a origem italiana desta cultura.
} 
inclusive criticadas pelo próprio More que se faz personagem no interior do livro. É preciso notar, porém, que alguns intérpretes contemporâneos ainda procuram assimilar o pensamento político de Thomas More aos ideais do catolicismo. Tais são os casos, por exemplo, de R. W. Chambers e P. Albert Duhamel², mas também do padre Edward Surtz, responsável pela edição Yale, uma das mais prestigiosas edições das obras de More. De acordo com esta interpretação, a Utopia seria uma defesa da vida corporativa contra o individualismo moderno e da vida comunal contra a moderna busca pelo ganho $^{3}$. Quanto às incongruências com os dogmas cristãos, Surtz sustenta que More não aprovaria a Utopia inteiramente. A república racional é uma admoestação e um chamado para que os cristãos façam melhor.

A interpretação da Utopia como um comunismo avant la lettre, imagem da sociedade sem classes, livre da propriedade privada, tal é a maneira pela qual alguns marxistas veem esta ilha ainda sem lugar na sociedade atual. Entretanto, Fredric Jameson em seu artigo intitulado The Politics of Utopia afirma que

em Thomas More (...) o que todo leitor costumeiramente extrai - assim como de Platão, também - é a abolição da propriedade privada. Isto alegadamente faz de Thomas More e Platão precursores do comunismo. Mas uma observação mais detida e um exame a teoria da natureza humana que sustenta estes dois ataques à instituição da propriedade privada revelam uma posição diferente: que a raiz de todo mal se encontra no ouro ou no dinheiro e que é a ganância (como um mal psicológico) que precisa ser de alguma forma reprimida por leis e organizações utópicas apropriadas, a fim de chegar a uma forma melhor e mais humana da vida. ${ }^{4}$

\footnotetext{
${ }^{2}$ Tb. Chambers, Thomas More, 1935, e Duhamel, "Medievalism of More's Utopia", 1977. Para este último a obra é escolástica tanto no método de construção, quanto no conteúdo e argumentação.

${ }^{3}$ Em seu artigo "Interpretations of Utopia", Surtz escreve que: "A fé cristã e a filosofia cristã atravessam as distinções de classe. Princípios básicos, como por exemplo, os de justiça social, integridade política, pureza religiosa, deveriam, portanto, ser comuns ao proletariado, ao burguês e ao nobre. Quanto mais uma pessoa compreende o cristianismo em todas as suas implicações, mais católica e menos ligada às classes ela se torna. E More não era apenas um cristão comum, mas o tipo ideal designado como 'santo'. (...) More, como veremos, quer que o espírito cristão informe indivíduos, classes e instituições” (1952, pg. 161). A sustentação de uma leitura católica por Surtz lhe valeu críticas contundentes da parte de Quentin Skinner em uma resenha deste último à edição Yale. Cf. Skinner, "Review Article: More's Utopia", 1967. ${ }^{4}$ Jameson, "The politics of Utopia", 2004, p. 36.
} 
A fundamentação de Utopia ou da República em uma suposta natureza humana e a identificação do mal a um, por assim dizer, desvio psicológico constituem para Jameson pontos de contraste entre estas obras e a crítica marxiana. É certo que More não é um marxista, mas a sua suposta subsunção dos problemas a um mal psicológico é uma questão que ainda merece discussão.

Há, no entanto, críticos que tendem a se ater tão somente ao caráter literário da obra. No vol. VIII do seu Histoire de France, Jules Michelet não só se refere à Utopia como um romance, mas ainda o considera enfadonho, raso na forma, prosaico no conteúdo e pouco imaginativo ${ }^{5}$. Outros que seguem esta via de leitura não são tão severos quanto Michelet. Ao contrário, C. S. Lewis o vê como um jeu d'esprit que "se torna inteligível e prazeroso tão logo nós tomamos pelo que é - uma obra de horas vagas [holiday work], um espontâneo transbordamento de espíritos intelectualmente elevados, um passatempo com debates, paradoxos, comédia e (acima de tudo) um trabalho de invenção, que assusta muitas lebres e não mata nenhuma". ${ }^{6}$ É também através de uma caracterização semelhante que Ronald Knox, cerca de 25 anos antes de Lewis, insere a obra na tradição literária humanista, afastando qualquer pretensão de reforma social:

Supor que More quisesse seriamente mudar os costumes da Inglaterra pelos da sua Utopia na vida real é esquecer a irresponsabilidade dos humanistas, seu gosto por sustentar paradoxos apenas por fazê-lo, e por sugerir dúvidas metódicas sem estarem preparados para sustentá-las. ${ }^{7}$

A interpretação literária mais recente lê a Utopia pela chave da sátira, um gênero poético, cuja principal característica é o serio ludere, ou seja, tratar de conteúdo sério de

\footnotetext{
${ }^{5}$ Michelet, Histoire de France. Tome huitième: Reforme, 1895, p. 261.

${ }^{6}$ Lewis, English literature in sixteenth century excluding drama, 1954, p. 167-169.

${ }^{7}$ Knox, "The charge of religious intolerance", 1929, p. 43-44.
} 
um modo mais leve ou mesmo divertido. Esta abordagem satírica tem se mostrado bastante frutífera, não só pela quantidade de pesquisadores ${ }^{8}$ que a adotaram, mas por seus resultados - ela inaugurou uma nova dimensão de estudos para além da velha oposição entre católicos e marxistas. Não se pode deixar de reconhecer que a forma e os recursos literários de que More lança mão são relevantes para a compreensão da obra e sem dúvida revelam aspectos e nuances de significados antes tênues, mas que, depois de ressaltados por certos estudiosos, não puderam mais ser ignorados por comentadores posteriores. ${ }^{9}$ Cabe, porém, reconhecer que ao afastar ou relegar para o segundo plano a teoria política, os comentadores desta linha interpretativa perdem a chave da compreensão da Utopia.

Intérpretes que se opõem a esta linha ${ }^{10}$ sublinham justamente a complexidade das instituições de Utopia, a análise brilhante da Europa deste período, além de referências a obras anteriores de teoria política, como aspectos que não podem ser ignorados. Hexter assinala que "o diagnóstico penetrante e detalhado dos males contemporâneos" e a "prescrição detalhada de remédios" por More na Utopia não encontra paralelo entre os humanistas, ultrapassando "os limites usuais e as limitações da sátira e da crítica social humanista"11. Diferente de Erasmo, que identifica e alveja com sua artilharia satírica e humanista os males sociais já tradicionalmente criticados

\footnotetext{
${ }^{8}$ Dentre eles podemos contar: Robert Elliott, A. R. Heiserman, John Traugott, T.S. Dorsh, W. J. Barnes, Harry Berger, Irma Ned Stevens, Arthur Kinney, R.S. Sylvester, Warren W. Wooden, etc. Cf. Logan, The meaning of More's Utopia, 1983, p. 6, n. 5 e n. 6. Cf. também Wooden, "Anti-scholastic satire in Sir Thomas More's Utopia", 1977, p. 29, n.1.

9 Wooden aponta como contribuições dos pesquisadores que adotam a abordagem satírica o reconhecimento da importância das sátiras de Luciano para a economia da obra, o destaque de traços indesejáveis da organização utopiana normalmente ignorados nos estudos sobre a obra e a complexidade da utilização de Hytlodeu como persona satírica. Cf. Wooden, "Anti-scholastic satire in Sir Thomas More's Utopia", p. 29-30.

10 Como exemplos de críticos desta linha, podemos enumerar: Edward Surtz, Robert Adams, Thomas White, George Logan, Jack H. Hexter, entre outros.

${ }^{11}$ Hexter, More's Utopia: the biography of an idea, p. 63.
} 
desde séc. XII, tão somente para prescrever "meros analgésicos e emplastros"12 (como quando "ele diz que o príncipe deve ser incorrupto e cuidar para que toda a casa seja incorrupta" "13 sem jamais "descobrir as raízes da doença"; More, em contraste, passa dos sintomas às fontes e apreende o caráter intrincado e as ramificações da estrutura social e da ação. "Suas realizações", afirma Hexter, "não estão em descobrir os males sociais em detalhe, mas em enfrentá-los como um todo relacionado, não como plantas individuais, mas como cultivos que, por mais que possam aparecer separados na superfície, têm uma raiz comum oculta."14 Esta clareza permite que More proponha remédios institucionais para males institucionais não imediatamente visíveis e bastante distantes de seus sintomas aparentes, como notam também Fleisher e Logan. Este último enxergará ainda na Utopia um método de análise moderno e sofisticado. ${ }^{15}$

Este grau de complexidade da abordagem moreana levou Robert Adams a afirmar, recuperando uma imagem das Grandes Navegações, que com a fala de Hitlodeu no jantar na casa de Morton, "um cabo da mente havia sido dobrado, aquele que divide o mundo medieval do moderno" ${ }^{\text {16 }}$. Para ele, em More, o roubo não é mais fruto numa natureza humana falível e imutável presente na pessoa do ladrão, não se trata mais de um pecado, mas de causas sociais e estruturais identificáveis e curáveis.

Assim, quer tenhamos a Utopia como um livro deliberadamente enigmático como Logan, quer concordemos com Hexter ou Surtz, que lhe atribuem clareza de sentido, o fato é que há interpretações divergentes que se constituíram ao longo do último século. Seria esta uma obra predominantemente satírica ou séria com elementos

\footnotetext{
${ }^{12}$ Hexter, More's Utopia: the biography of an idea, p. 64.

${ }^{13}$ Hexter, More's Utopia: the biography of an idea, p. 110-111.

${ }^{14}$ Hexter, More's Utopia: the biography of an idea, 1965, p. 66.

${ }^{15}$ Cf. Fleisher, Radical reform and political persuasion in the life and writings of Thomas More, p. 8; cf. tb. Logan, The meaning of More's Utopia, p. 60.

${ }^{16}$ Adams, The better part of valor: More, Erasmus, Colet, and Vives, on humanism, war, and peace, 1496-1535, p 125-126.
} 
satíricos ${ }^{17}$ Se é satírica, seria Hitlodeu o veículo ou o alvo da sátira? Se se trata de uma obra filosófica, a qual tradição se vincula? É medieval ou moderna? Todas estas questões foram respondidas de maneiras muito distintas pelos comentadores. ${ }^{18}$

Nesta tese procuraremos mostrar que o caráter literário não invalida o seu caráter filosófico. Mais do que isso, a sua forma cumpre o papel de doadora de sentido, numa obra que tem como propósito tratar de temas da mais alta relevância para a república. Trata-se de uma obra humanista, filha do seu tempo e que dialoga com os problemas de sua época. Deste modo, ela não pode ser confundida com outras imagens de mundos paralelos anteriores, que fazem parte de épocas muito distintas da sua, com outra escala de valores e outra visão de mundo.

Como obra de um erudito formado na studia humanitatis, ela enfeixa em si uma rede de tradições na qual se inscreve e da qual, ao mesmo tempo, se distingue. Embora tenha elementos satíricos, a Utopia não pode ser subsumida à sátira antiga sem mais.

A discussão desenvolvida na tese está estruturada em 4 capítulos:

O primeiro capítulo é dedicado à análise do caráter estético da obra. Procuramos mostrar, em primeiro lugar a distância que separa esta obra do século XVI de outras projeções anteriores de sociedade perfeita. Depois disso, mostraremos como, ao mesmo tempo, não está inteiramente desligada desta tradição. Como se trata de tomar em consideração aspectos literários, a discussão neste capítulo não remeterá a outras obras de filosofia política. Por isso, fazemos referência, por exemplo, ao Críton, por conta da descrição da Atlântida, mas não à República. Por fim, a partir de uma exegese da obra,

\footnotetext{
${ }^{17}$ Surtz que compreende a Utopia como fundamentalmente séria em seus objetivos, a certa altura do artigo "Interpretations of Utopia", chega a dizer que a grande questão é saber em que medida este verdadeiro livro de ouro (libellus uere aureus) é sério ou divertido. E completa: "ninguém ... é tão tolo para afirmar que o trabalho é inteiramente brincadeira ou inteiramente sério. No entanto, as opiniões dos acadêmicos e biógrafos divergem violentamente quanto à predominância do jogo ou da gravidade em Utopia." Surtz, "Interpretations of Utopia", p. 157.

${ }^{18}$ Cf. Ames, Citizen Thomas More and his Utopia, p. 5; cf. tb. Logan, The meaning of More's Utopia, passim; Surtz, "Interpretation of Utopia", 1952, passim, entre outros.
} 
buscaremos os elementos formais que permitem extrair o seu significado político pelo arranjo inédito dos elementos tradicionalmente considerados satíricos.

No segundo capítulo a utopia é discutida como uma obra eminentemente filosófica. Neste caso, serão buscadas as suas referências anteriores em obras tais como a República de Platão (como também as Leis) e a Política de Aristóteles. Neste caso, não se trata de analisar as obras em si, mas do interesse que elas têm como referência à Utopia, a fim de se discernir como More compreende, por exemplo, o conceito de justiça, que é central na obra.

No terceiro capítulo será discutida a inserção da Utopia no contexto filosófico da Inglaterra com o objetivo de se procurar determinar o que More tem em vista ao mobilizar elementos da tradição filosófica. A Utopia é uma obra de um homem inserido nos negócios da república e preocupado com eles, tendo mesmo por diversas vezes interferido, inclusive de forma contundente, nos debates públicos, como no caso da defesa dos humanistas em Oxford ou em sua manifestação em favor de Erasmo contra as investidas dos Teólogos de Louvain. A interpretação da Utopia exige, portanto, que ela também seja situada em relação a estas questões.

Nas considerações finais procuramos então extrair uma compreensão da obra a partir do percurso realizado nos capítulos anteriores. Trata-se de, seguindo nossa hipótese inicial, buscar decifrar o sentido desta obra, mostrando que a Utopia é uma obra filosófica e literária moderna, e que este sentido, tributário da filosofia antiga e do humanismo erasmiano, se constitui pela interpenetração de forma e conteúdo. 


\section{Utopia, Eutopia: A vida feliz como uma imagem poética}

Utopia não inaugura a imagem de um lugar feliz e remoto. Diversos povos ao longo da história produziram relatos de sonhos ou lugares míticos, eras passadas ou futuras. A este respeito, Lewis Munford chega a afirmar que "[o] homem caminha com seus pés no chão e a sua cabeça no ar; e a história do que aconteceu na terra - a história das cidades e dos exércitos e de todas as coisas que tiveram corpo ou forma - é somente a metade da história da humanidade" ${ }^{\prime 19}$. De fato, na tradição ocidental, Hesíodo, no poema Os Trabalhos e os dias ${ }^{20}$, descreve uma era mítica, sob o reinado de Cronos, em que os homens viviam como deuses, livres da faina incessante, da velhice e da dor, numa terra benfazeja que lhes prodigalizava os frutos espontaneamente, sem a necessidade do cultivo.

Se queres, com outra estória esta encimarei;

Bem e sabiamente lança-a em teu peito!

[como da mesma origem nasceram deuses e homens.]

Primeiro de ouro a raça dos homens mortais

Criaram os imortais, que mantêm olímpias moradas.

\footnotetext{
${ }^{19}$ Mumford, The story of Utopias, p. 12.

${ }^{20}$ Claeys considera que Os Trabalhos e os dias é um dos mais antigos relatos utópicos, ao lado do Gênesis: "Embora Thomas More tenha criado a forma da utopia moderna, ele não foi o primeiro a escrever uma utopia. De fato, lugares melhores foram descritos pelo menos desde as primeiras formas de escrita, e muitas de tais descrições são claramente o resultado de tradições orais anteriores. As primeiras obras utópicas são mitos de uma era ou raça de ouro no passado e de paraísos terrestres como o Éden. ". Claeys, The utopian readers, p. 6.
} 
Eram do tempo de Cronos, quando no céu este reinava; Como deuses viviam, tendo despreocupado coração, Apartados, longe de penas e misérias; nem temível velhice lhes pesava, sempre iguais nos pés e nas mãos, alegravam-se em festins, os males todos afastados, morriam como por sono tomados; todos os bens eram para eles: espontânea a terra nutriz fruto trazia abundante e generoso e eles, contentes, tranqüilos nutriam-se de seus pródigos bens. ${ }^{21}$

No poema de Hesíodo, esta era é colocada no início de uma sucessão de outras, sendo que a inferioridade das seguintes é simbolizada pela qualidade dos metais aos quais estão vinculadas (ouro, prata, bronze, ferro). Esta sucessão, a bem dizer, não é aquela de um tempo homogêneo e linear, mas se configura como uma alternância entre diké e hybris.

Cada raça possui sua temporalidade própria, sua idade, que exprime sua natureza particular e que, a título mesmo de seu gênero de vida, suas atividades, suas qualidades e seus defeitos, define seu status e a opõe a outras raças. Se a raça de ouro é dita "a primeira", não é porque ela apareceu um belo dia, antes das outras, em um tempo linear e irreversível. Ao contrário, se Hesíodo a figurou no início de seu relato é porque ela encarna as virtudes - simbolizadas pelo ouro - e ocupa o topo de uma escala de valores atemporais. $^{22}$

A mudança segue o ritmo de um tempo cíclico num cosmos ordenado. Trata-se, portanto, do tempo cíclico da própria natureza.

Feito este reparo, é significativo que a Era de Ouro tenha se dado sob o domínio de Cronos. Cronos é aquele que cria o espaço entre o céu e a terra, permitindo assim o aparecimento da luz e da fertilidade sobre esta última. O seu tempo é considerado um tempo antes dos tempos ${ }^{23}$, período que antecede as lutas por supremacia que

\footnotetext{
${ }^{21}$ Hesíodo, Os trabalhos e os dias, 1996, p. 31

${ }^{22}$ Vernant, Mythe et pensée chez les grecs. In : Oeuvres, p. 258.

23 "Era do ouro, quando os homens não estavam ainda separados, era do ouro que por vezes chamamos também tempo de Cronos, tempo anterior ao momento em que se inicia a luta entre Cronos com os Titãs e Zeus com os Olímpicos, em que o mundo divino não está ainda entregue à violência brutal. É a paz, um tempo antes dos tempos". Vernant, L'Universe, les dieux e les hommes. In: Oeuvres, p. 46-47.
} 
organizarão hierarquicamente o universo sob a égide de Zeus. E a vitória de Zeus sobre seu pai representa um domínio sobre o tempo. Com efeito, a luta entre as duas gerações de deuses, os Titãs e os Olímpicos, é uma luta entre as potências primordiais da natureza e a ordem humana em construção - os Titãs representam estas forças naturais primordiais, enquanto que os Olímpicos encarnam, cada um deles, as atividades próprias dos homens. Ora, o caráter elementar e primordial destas forças, livres ainda da ação dos homens e reinando plenas, é o que faz com que os Titãs sejam muitas vezes representados como monstros assustadores, potências dominantes porque ainda não dominadas.

No caso específico de Cronos uma das manifestações deste caráter terrível e assustador está no ato de devorar seus filhos, o qual encontraria uma de suas representações mais conhecidas no famoso quadro de Goya. Este ato manifesta a própria natureza de Cronos, o tempo que devora aquilo que dele nasce. Quando Zeus se ergue contra ele, força-o a vomitar seus irmãos mais velhos, isto é, liberta-os do tempo, tal como antes o próprio Cronos libertara seus irmãos Titãs do ventre de Gaia ${ }^{24}$.

Mas o que é o tempo ainda não dominado, ainda não conhecido? É um tempo sem passado ou futuro, a imersão na natureza como um eterno presente. Daí que a imagem de Cronos seja tão ambígua: o deus da Era de Ouro e o deus da melancolia. Com efeito, este eterno presente é a ausência de um antes ou depois para cada experiência, de modo que cada alegria ou prazer, assim como cada tristeza e dor, parece compor todo o universo. Algo de semelhante pode ser encontrado no episódio dos lotófagos na Odisséia. Como apontam Adorno e Horkheimer, o efeito da lótus sobre aqueles que a ingeriam consistia em fazê-los regredir "ao estado primitivo sem trabalho

24 "É ele, Cronos, quem não hesitou em cortar as partes sexuais de seu pai. Ao ousar este ato, ele desbloqueou o universo, criou o espaço, deu nascimento a um mundo diferenciado, organizado. Este ato positivo compreende também um aspecto sombrio: é ao mesmo tempo uma falta da qual ele deverá pagar o preço." Vernant, L'Universe, les dieux e les hommes. In: Oeuvres, pgs. 27. 
e sem luta na "fértil campina", e quando Ulisses os arrasta à força de volta para os

barcos, eles vão "debulhados em lágrimas" e têm que ser amarrados sob os bancos, prosseguindo na viagem com "o coração amargurado" 25 .

Roma produziu sua própria versão da Era de Ouro. Segundo Gregory Claeys ${ }^{26}$, há relatos a respeito em obras de Sêneca, Catulo e Horácio. Mas o mais famoso deles é aquele que se encontra nas Metamorfoses de Ovídio.

Áurea era aquela primeira idade, na qual, com ninguém para obrigar, sem nenhuma lei, de sua própria vontade, mantinha-se a fé e agia-se corretamente. Não havia medo de punição, nem palavras ameaçadoras a serem lidas em tábuas de bronze, nenhuma turba suplicante encarava temerosa a face de seu juiz, mas sem juízes viviam seguros. Não tinha ainda o pinheiro, cortado de suas montanhas nativas, descido dali para a planície aquática para visitar outras terras, os homens não conheciam outros litorais, exceto os seus próprios. Não estavam ainda as cidades cercadas por fossos escarpados, não havia retas trombetas de bronze, sinuosos elmos, espadas. Não havia necessidade alguma de homens armados, pois as nações, livres dos alarmes da guerra, passavam os anos em ócio gentil. A própria terra, sem ser compelida, intocada por enxada ou arado, por si mesma dava todas as coisas necessárias. E os homens, contentes com o alimento que brotava sem que ninguém cultivasse, colhiam os frutos do arbuto, morangos das encostas das montanhas, cerejas silvestres e mirtilos que brotavam generosamente das bagas espinhentas, e bolotas que caiam das abundantes árvores de Júpiter ${ }^{27}$. Então a primavera era eterna, e zéfiros gentis com seus sopros cálidos brincavam com as flores que desabrochavam sem serem semeadas. Anônima a terra, não-titulada, produzia grãos em abundância e os campos, ainda que incultos, embranqueciam com ricos trigais. Riachos de leite e de doce néctar fluíam, e mel dourado era destilado do carvalho verdejante $^{28}$.

Diferente de sua similar grega, a aurea aetas latina é descrita inicialmente como

um negativo de Roma; como um lugar em que não havia leis, nem tribunais ou juízes,

\footnotetext{
${ }^{25}$ Horkheimer e Adorno, Dialética do esclarecimento, p. 67-68. No mesmo trecho eles fazem ainda o seguinte comentário: "A tentação que lhe é atribuída [isto é, à lótus,] não é talvez outra coisa senão a da regressão à fase da coleta dos frutos da terra e do mar, anterior à agricultura, à pecuária e mesmo à caça, em suma, a toda a produção. Não é certamente por acaso que a epopéia liga a imagem do país de Cocanha à alimentação de flores (...). O hábito de comer flores - que se pratica à sobremesa no Oriente próximo e que as crianças européias conhecem das massas assadas com leite de rosas e das violetas cristalizadas - é a promessa de um estado em que a reprodução da vida se tornou independente da autoconservação consciente e o prazer de se fartar se tornou independente da utilidade de uma alimentação planejada."

${ }^{26}$ Claeys, Utopia: a história de uma idéia, p.18.

${ }^{27}$ Trata-se do carvalho.

${ }^{28}$ Ovídio, Metamorphoses, p. 8-11.
} 
nem exércitos com suas trombetas. O ponto de vista do poeta é o do citadino que alcança a imagem do início dos tempos a partir de uma série de negações, que funcionam como uma espécie de arqueologia. Uma vez tendo limpado o terreno dos vestígios da civilização, revela-se a natureza infinitamente doadora e prodigiosa. Passase da abundância para a fantasia que ressoa à Cocanha e às Histórias Verdadeiras de Luciano. Mas aqui, embora também fosse o tempo de Saturno ${ }^{29}$, a única menção ao tempo é a eterna primavera. Os elos mais fortes com o poema de Hesíodo estão na ausência do trabalho e na generosidade da natureza. Estes relatos de uma aurora dourada de liberdade e bem-aventurança remetem-nos a ainda outro princípio feliz e para sempre perdido, em que a humanidade também estava livre das penas da labuta diária. Trata-se da descrição do jardim do Éden, que encontramos em Gênesis 2. 7-17:

7. Então formou o Senhor Deus ao homem do pó da terra, e lhe soprou nas narinas o fôlego de vida, e o homem passou a ser alma vivente.

8. E plantou o Senhor Deus um jardim no Éden, da banda do Oriente, e pôs nele o homem que havia formado.

9. Do solo fez o Senhor Deus brotar toda sorte de árvores agradável a vista e boa para alimento; e também a árvore da vida no meio do jardim, e a árvore do conhecimento do bem e do mal.

10. E saía um rio do Éden para regar o jardim, e dali se dividia repartindo-se em quatro braços.

11. O primeiro chama-se Pisom; é o que rodeia a terra de Havilá, onde há ouro.

12. O ouro dessa terra é bom; também se encontram lá o bdélio e a pedra de ônix.

13. O segundo rio chama-se Giom; é o que circunda a terra de Cuxe.

14. O nome do terceiro rio é Tigre; é o que corre pelo oriente da Assíria. E o quarto é o Eufrates.

15. Tomou, pois, o Senhor Deus ao homem e o colocou no jardim do Éden para o cultivar e o guardar.

16. E lhe deu esta ordem: De toda árvore do jardim comerás livremente,

17. mas da árvore do conhecimento do bem e do mal não comerás; porque no dia em que dela comeres, certamente morrerás.

Distinta de suas contrapartes grega e romana, em que nenhum pecado leva à expulsão do paraíso, na história adâmica o homem recebe como castigo a necessidade

\footnotetext{
${ }^{29}$ Saturno é mencionado no trecho imediatamente posterior. Cf. Ovídio, Metamorphoses, p. 11.
} 
de ter que extrair, com suor e fadiga, o alimento de uma terra agora amaldiçoada ${ }^{30}$. Esta queda é apresentada em Gênesis 3. 17-24:

17. E a Adão disse: Visto que atendeste a voz de tua mulher, e comeste da árvore que eu te ordenara não comesses: maldita é a terra por tua causa: em fadiga obterás dela o sustento durante os dias de tua vida.

18. Ela produzirá também cardos e abrolhos, e tu comerás a erva do campo.

19. No suor do teu rosto comerás o teu pão, até que tornes à terra, pois dela foste formado: porque tu és pó e ao pó tornarás.

20.E deu o homem o nome de Eva à sua mulher, por ser a mãe de todos os seres humanos.

21.Fez o Senhor Deus vestimenta de peles para Adão e sua mulher, e os vestiu.

22.Então disse o Senhor Deus: eis que o homem se tornou como um de nós, conhecedor do bem e do mal; assim, para que não estenda a mão, e tome também da árvore da vida, e coma e viva eternamente:

23. o Senhor Deus, por isso, o lançou fora do jardim do Éden, a fim de lavrar a terra de que fora tomado.

24.E, expulso o homem, colocou querubins ao oriente do jardim do Éden, e o refulgir de uma espada que se revolvia, para guardar o caminho da árvore da vida.

Não há retorno ao Éden, a queda encerrou o paraíso terrestre num passado sem volta. Embora não faltassem tentativas de localizá-lo, nas diversas viagens empreendidas ao oriente ${ }^{31}$ a partir das indicações extraídas dos livros de Gênesis (2:14) e Ezequiel (28.13), os querubins e a espada refulgente não deixam dúvidas quanto à proibição. Já o domínio de Cronos/Saturno era rememorado anualmente nas Saturnálias romanas e na Kronia, festival ateniense comemorado no hécatombaion, primeiro mês do calendário daquela região da Grécia, que coincidia com a época da colheita. "Que todo homem seja tratado igualmente, escravo e homem livre, pobre ou rico", assim proclama o legislador de Cronos, Cronossolon ${ }^{32}$, a primeira lei da Saturnália ${ }^{33}$. Mas, o domínio de

\footnotetext{
${ }^{30}$ Neste aspecto, a queda de Adão se assemelha mais a outro mito que antecede a sucessão inexorável das raças: o de Prometeu e Pandora. "O mito de Prometeu comporta uma moral tão clara que não é necessário que Hesíodo a desenvolva; é suficiente deixar o relato falar: pela vontade de Zeus que - para se vingar do roubo do fogo, ocultou do homem sua vida, ou seja, seu alimento - os homens tiveram que se dedicar ao trabalho; é preciso aceitar esta dura lei divina e não poupar seus esforços e suas penas". Vernant, Mythe et pensée chez les grecs. In: Oeuvres, p. 255.

31 "Para os cristãos, por muito tempo o jardim do Éden foi considerado localizável, mas só era permitida sua aproximação, a entrada era proibida, o que aparece em contos inúmeros, como 'O romance de Alexandre', de Pseudo-Calisteno, em 200 d.C. A localização do paraíso terreno permaneceu como objeto de dúvida e especulação". Albornoz, "Em busca do Éden Eldorado. A utopia de Cristóvão Colombo", 2010 , p. 86.

${ }^{32} \mathrm{O}$ nome, composição de Cronos e Sólon, é uma referência jocosa ao legislador grego.

${ }^{33}$ Cf. Luciano, Saturnalia, vol. 6, p. 107.
} 
Cronos permanece encerrado no transitório momento da festa. Na Saturnália de Luciano, Cronos também diz a Cronossolon: "Meu reinado inteiro é por sete dias". A propósito deste diálogo, referindo-se ao momento em que o sacerdote-legislador se queixa de sua pobreza e roga a Cronos que a reverta, Robert Elliot comenta:

A questão é esta: pelo período da Saturnália, Cronossolon e seus companheiros desfrutarão das coisas boas da vida em pé de igualdade com os ricos. Durante este tempo sagrado a Idade de Ouro voltará novamente à Terra - este, afinal de contas, é o significado do festival. Mas isto é uma coisa muito diferente, aponta Cronos, de mudar a maneira como as coisas são na vida usual e tornar todos iguais; tais questões são da jurisdição de seu filho Zeus, não da sua. Claramente, se não se acredita na boa vontade de Zeus ou mesmo na sua existência, estas se tornam questões para o próprio homem ${ }^{34}$.

Em todos estes textos, portanto, encontramos idades ideais distanciadas no tempo. Todavia, no que tange à Utopia de Morus, o que a torna remota não é a sua localização no tempo, mas no espaço. Ela não está encapsulada num tempo inteiramente outro e qualitativamente distinto ou num passado irreversível; ela pertence ao presente. Porém, esta característica é também compartilhada por outras ilhas extraordinárias. A Ilha do Sol de que falava Iâmbulo ${ }^{35}$ e a ilha de Panchéia apresentada na Escrita sagrada de Euêmero $^{36}$ são ambas colocadas como contemporâneas a seus autores e estão isoladas em lugares longínquos.

A viagem à Ilha do Sol é contada por Diodoro Sículo, que por sua vez, não a teria ouvido diretamente do protagonista, mas de um terceiro. "Havia um certo Iâmbulo $^{37}$ (...) que, enquanto viajava por terra para a região de especiarias da Arábia, ele

\footnotetext{
${ }^{34}$ Elliot, The Shape of Utopia, p. 8.

${ }^{35}$ O relato de Iâmbulo encontra-se no livro II (II 55-60) da Biblioteca Histórica de Diodoro Sículo. Não há consenso a respeito do próprio Iâmbulo: se se trata de uma pessoa real ou "um simples personagem inventado pela tradição oral helenística ou pelo próprio Diodoro". Cf. Robbio, "La Travessia de Yambulo per las Islas del Sol", p. 31-32.

${ }^{36}$ A ilha de Panchéia ou Panchaia é descrita na Hiera Anagrafon (que significa Inscrição Sagrada, por vezes também traduzida por História Sagrada) e somente sobreviveu como fragmento. Sua principal fonte é Diodoro Sículo. Cf. Bibliotheca Historica 5,41-46 and 6,1,2.

${ }^{37}$ Segundo Robbio, o nome Iâmbulo "poderia ser um composto de iambós e oulós significando 'destructor de Iambos' ou poderia ser uma variação quase homófona de iambylos, significando 'difamador' ainda que Kobishchanow e Winiarczyk considerem que possa ser de origem nabatéia". Cf. Robbio, "La Travessia de Yambulo per las Islas del Sol", p. 31.
} 
e seus companheiros foram capturados e tornados cativos por alguns ladrões"38. Iâmbulo e um companheiro, tendo sido, num primeiro momento, escolhidos como pastores, são mais tarde raptados por alguns etíopes para executarem um ritual de purificação na costa da Etiópia. O ritual incluía embarcá-los para uma viagem sem volta, em um mar tormentoso, rumo à Ilha do Sol. Ao desembarcar na ilha, Iâmbulo é recebido docemente por belas criaturas de quatro cúbitos ${ }^{39}$ de altura, ossos flexíveis como músculos, pele aveludada e nenhum pêlo no corpo, exceto na cabeça, sobrancelhas e cílios. Estes seres têm línguas bífidas que os tornam capazes de falar com duas pessoas ao mesmo tempo, imitar todas as línguas humanas e o canto das aves. A ilha (ou ilhas, já que se trata de um arquipélago composto por sete ilhas) fica no Oceano Índico, nas proximidades da linha do Equador, propiciando um clima ameno e produzindo uma natureza generosa.

[56.7] O seu clima é em sua maior parte temperado, como dissemos, e como eles vivem no equador, eles não sofrem nem com calor, nem com frio. Mais do que isso, os frutos em sua ilha amadurecem durante o ano inteiro (...). E o dia tem sempre a mesma duração da noite e ao meio dia nenhum objeto projeta sua sombra, pois o sol está sempre no zênite. (...)

[57.3] Há também na ilha, dizem eles, fontes de água: as fontes de água morna servem bem para o banho e o alívio da fadiga; as de água fria, excelentes em suavidade, possuem o poder de contribuir para a boa saúde.

Pode-se dizer que nestas imagens utópicas de tempos ou lugares longínquos e felizes, a natureza provedora é um tópico recorrente e parece predominar sobre os demais elementos. Na descrição da Ilha do Sol, por exemplo, apenas umas poucas linhas são dedicadas à organização política e social. Tudo o que sabemos é que seus

\footnotetext{
${ }^{38}$ Diodorus Sículus, Diodorus of Sicily, p. 65.

${ }^{39}$ Um cúbito é a medida de um antebraço.
} 
habitantes vivem em comunidades constituídas por cerca de 400 pessoas, e que os mais velhos governam ${ }^{40}$.

[57.1] Estes ilhéus vivem em comunidades baseadas na afinidade (kinship) e, sobre a organização política, não há mais do que quatrocentos membros reunidos desta maneira; e os membros passam o tempo nas pradarias, a terra os suprindo com todas as coisas para o seu sustento; em razão da fertilidade da ilha e da suavidade de seu clima, os alimentos se produzem por si mesmos, numa quantidade maior que o suficiente para as suas necessidades.

A esta brevíssima nota sobre a organização da ilha, seguem-se detalhes sobre seus frutos e suas fontes. Ficamos sabendo ainda como é a sua escrita e que não há casamento entre eles; as crianças são criadas em comum e são utilizados alguns expedientes para que nem mesmo suas mães saibam quem são seus verdadeiros filhos, de modo que não haja facções.

[58.1] Não se casam, disseram-me, mas têm suas crianças em comum e criam as que nascem como se fossem suas e as amam igualmente. Enquanto as crianças são pequenas, as nutrizes intercambiam os bebês freqüentemente para que nem mesmo as mães possam reconhecer os seus próprios. Por isso, ao não haver nenhuma distinção entre eles, passam a vida sem facções políticas e têm a concórdia como seu mais alto valor. $^{41}$

Ainda assim, estes elementos são mencionados de passagem, semeados de forma dispersa em um discurso que fala essencialmente sobre a abundância e o maravilhoso. A narrativa se dá de tal modo, que as escassas linhas sobre os costumes emergem rapidamente para o relato mais uma vez mergulhar na natureza com seus animais exóticos e mesmo fantásticos (como um animal redondo com quatro bocas, cujo sangue é capaz de curar um membro decepado). Mesmo o conhecimento dos astros não traz

\footnotetext{
40 "[58.6] O mais velho de cada grupo exerce regularmente a autoridade como um tipo de rei e todos o obedecem. Cada vez que o primeiro cumpre cento e cinqüenta anos deixa a vida, de acordo com a lei, e o mais velho depois dele herda a autoridade". Diodorus Sículus, Diodorus of Sicily, p. 77.

${ }^{41} \mathrm{Na}$ tradução deste trecho vali-me em parte da solução adotada por Robbio, op. cit., p. 37
} 
nenhuma conseqüência prática e a peculiar ausência de sal nas águas do mar que banham a ilha não se deve a nenhuma ciência e nem ao domínio de nenhuma técnica.

Assim como Utopia, estas histórias seriam, segundo Ernest Bloch, tributárias de um alargamento de experiência, no caso delas, proporcionado pelas incursões de Alexandre. "A utopia helenista foi reforçada e ilustrada pelo descobrimento da Índia de forma muito análoga à utopia dos tempos modernos pelo descobrimento da América: o espaço do Estado encontrou um lugar geométrico."42 Por outro lado, no caso da Ilha do Sol, afirma Bloch, a sua natureza fabulosa funcionaria como um substituto da técnica ${ }^{43}$. De forma que não seria à toa que Iâmbulo localiza seu arquipélago nos mares do sul, junto ao equador.

Panchéia é um pouco diferente: não há uma natureza extraordinária ou que produza por si mesma, nem estranhos animais ou habitantes com a língua bífida. $\mathrm{O}$ mesmo se dá no caso das ilhas vizinhas. Por certo, a sua localização no mar das Arábias, produz uma natureza rica, com variedade de flora e fauna: o cipreste, o louro, a mirra podem ser encontrados na ilha, assim como pássaros, elefantes e leões. Entretanto, trata-se de espécimes dentro da ordem usual das coisas. No que se refere à organização social, a imagem é de uma sociedade de homens comuns, com sacerdotes, artesãos e pastores. Mas, Panchéia não parece nem mesmo ser uma sociedade ideal, uma vez que há criminosos, inclusive parte da ilha é ocupada por ladrões, sendo que a pena de morte é aplicada aos crimes mais graves. Embora a economia seja primitiva, não há comunidade de bens, e os agricultores e pastores obtêm seus ganhos através do seu trabalho. Por isso, Winiarczy caracteriza a descrição de Panchéia como realista ${ }^{44}$ ("Euêmero tentou criar a ilusão de que ele estava descrendo uma ilha real no Oceano

\footnotetext{
${ }^{42}$ Bloch, O principio esperança, p. 45.

${ }^{43}$ Bloch, O princípio esperança, p. 46.

${ }^{44}$ Winiarczy, The "Sacred History" of Euhemerus of Messene, p. 77.
} 
Índico" ${ }^{45}$ ) e explica este traço peculiar pelo deslocamento de interesse: "sua descrição provê somente o pano de fundo para a apresentação das origens da religião" ${ }^{\text {"46 }}$. A História Sagrada, na qual se inscreve Panchéia, parece servir mais como ocasião para sustentar a tese de que os deuses foram na verdade originalmente homens. De forma que aqui, neste caso, a exceção parece confirmar a regra.

Mas e quando passamos à Utopia? Há duas linhas de corte que funcionam como coordenadas de tempo e espaço e que simultaneamente estabelecem os dois principais níveis narrativos de Utopia. Todas as duas são marcadas pela figura do rei.

Certa vez, que o invictíssimo rei da Inglaterra, Henrique VIII de seu nome, um dos mais prendados em todas as artes de um príncipe egrégio, teve de dirimir negócios de não pequena monta com o sereníssimo príncipe Carlos de $\mathrm{Castela}^{47}$, enviou-me como seu legado oficial a Flandres para deles tratar e em consequência os levar a bom termo ${ }^{48}$.

É com este pequeno relato que Morus inicia a sua Utopia e é deste modo que a melhor república é posta no seu tempo, o tempo de seu autor, ou mais precisamente o do seu encontro fíctício com o viajante-narrador, Hitlodeu, em 1515. Já a estada do marinheiro Hitlodeu junto aos utopianos se passa alguns anos antes, por ocasião da quarta viagem de Américo Vespúcio às Américas ${ }^{49}$, como ficamos sabendo pela apresentação entusiasmada de Peter Giles:

\footnotetext{
${ }^{45}$ Winiarczy, The "Sacred History" of Euhemerus of Messene, p. 79

${ }^{46}$ Winiarczy, The "Sacred History" of Euhemerus of Messene, p. 78.

${ }^{47}$ Trata-se do futuro imperador Carlos V.

${ }^{48}$ Cf. Utopia, pg. 46; Vtopia, pgs. 225-227. Todas as referências à Utopia serão feitas à edição padrão de Yale (Utopia. Surtz, Edward e Hexter J. H. (ed), The Yale Edition of the Complete Works of St. Thomas More, vol. 4, London: Yale Unversity Press, $3^{\text {a }}$ ed., 1993.) e em seguida à edição crítica da Calouste (Vtopia ou a melhor forma de governo. Nascimento, Aires A. (trad.), Lisboa: Fundação Calouste Gulbenkian, $3^{\mathrm{a}}$ ed., 2015.)

${ }^{49}$ As viagens de Vespúcio ocorrem entre 1499 e 1504 e o seu relato Quatuor Americi Vespuccii Navigationes foi publicado em 1507. Cf. More, L'Utopie, 1987, pg. 86.
} 
deixou aos irmãos os bens de família que tinha na sua pátria (é português) e na mira de lançar os olhos pelo orbe da terra, juntou-se a Américo Vespúcio e nas três últimas das suas quatro viagens, cujo relato constitui já objecto de leitura em diversas partes, foi seu companheiro inseparável, se excluirmos que, na última, não regressou com ele. ${ }^{50}$

Quanto à sua localização geográfica, entre lacunas e esquecimentos, os espaços são propositadamente embaralhados em meio ao périplo de Hitlodeu. Pelas primeiras indicações fornecidas por Peter Giles, que é quem narra a More neste momento, sabemos que:

Efectivamente, intentou ele [Hitlodeu] tudo até arrancar a Américo autorização para ser ele um dos vinte e quatro que foram deixados no Castelo ${ }^{51}$, no ponto mais afastado a que chegou a última expedição daquele. (...) Aliás, depois de Vespúcio ter partido, percorreu ele com mais cinco companheiros do Castelo muitas regiões até que, por uma maravilha da sorte, foi ter à Taprobana ${ }^{52}$ e daí chegou a Calecut, onde encontrou, a bom momento, as caravelas portuguesas e finalmente, contra tudo o que se poderia esperar, regressa à sua pátria. ${ }^{53}$

Mais adiante, quando Peter terminou seu relato, então o próprio Hitlodeu toma a palavra e se dirige a ambos:

Narrou-nos ele [Rafael], pois de que modo após a partida de Vespúcio, ele e os companheiros que haviam ficado no Castelo, a pouco e pouco, haviam conseguido estabelecer contactos e trocar presentes de forma que, tendo sido acolhidos pelos habitantes daquela terra, não só já andavam despreocupadamente entre eles, mas até o faziam em modos familiares, a ponto de se tornarem benquistos e amigos de um dos príncipes (cujo nome e lugar de origem perdi da memória). Relatava ele que na sua liberalidade thes haviam prodigalizado graciosamente, a ele e aos seus cinco companheiros, meios de transporte e provisões com um guia indefectível para a viagem

\footnotetext{
${ }^{50}$ Utopia, pg. 50; Vtopia, pg. 232.

51 A edição inglesa de Yale optou por traduzir o original "castello" por "fort"; o tradutor da edição Calouste optou por se manter próximo da formulação original, pois "castelo" também tem o sentido de praça forte. Na nota 76, o tradutor português afirma que "Américo Vespúcio, nas Quatuor navigationes, Saint-Dié, 1507, fl. Vr, relata que num lugar fortificado, (fortim ou castelo) foram deixados vinte e quatro homens, com 12 espingardas e muitas armas, com mantimentos para seis meses, tendo regressado a Lisboa a 28 de junho de 1504."

${ }^{52}$ Ceilão

${ }^{53}$ Utopia, pg. 50; Vtopia, pg. 232-233.
} 
(que iriam realizar em jangadas por água e por carroças por terra). Encaminhava-os ele a outros príncipes, a quem eram dirigidos com recomendações adequadas. ${ }^{54}$

Mas se analisarmos mais de perto, não ocorre propriamente que Hitlodeu tome a palavra: um traço importante deste trecho é o fato de que o relato de Hitlodeu está posto na forma de discurso indireto. Na verdade, é More quem fala. Mesmo se considerarmos o diálogo em que Giles se dirige diretamente a More, é este último quem nos relata o que Giles e Hitlodeu lhe disseram. No trecho citado acima, por exemplo, quem esqueceu o nome do príncipe e do país? Quem é este “eu”? Ora, o eu é More. Também é ele que escolhe o que é importante relatar e o que se deve omitir.

Mas, onde fica Utopia, afinal? Sabemos que não fica nas proximidades da linha do Equador, região em que "tudo é árido e estéril" e onde "os homens são tão ferozes quanto bestas e não menos perigosos". Mas tudo o que podemos fazer é supor que Hitlodeu se deparou com a Utopia em algum ponto no Novo Mundo entre o Brasil e o Ceilão. O fato é que Thomas More silencia a respeito de como Hitlodeu chegou à Utopia. Sua localização permanece indeterminada, obscura.

Apesar disso, ou por isso mesmo, Utopia não está colocada fora de alcance. $\mathrm{O}$ efeito que se tem é o de que ela está em algum lugar na Terra e é virtualmente acessível, pois Hitlodeu também não chega até ela por nenhum expediente sobrenatural. Nenhum deus, nenhuma tempestade o carrega para um lugar fora do tempo como no mito de $\operatorname{Bran}^{55}$. Também não se depara com rios de vinho ou árvores encantadas, como nas

\footnotetext{
${ }^{54}$ Utopia, pg. 50; Vtopia, pg. 233-234.

${ }^{55}$ No mito irlandês da viagem de Bran, ele e seus companheiros conhecem uma mulher muito bonita e decidem partir com ela para, Sid, um mundo de maravilhas. Lá, cada um deles passou a viver com uma bela mulher. Pouco tempo depois, retornam à Irlanda. Quando a embarcação se aproxima da praia, Bran se identifica como o filho de Febal, mas as pessoas conheciam seu nome apenas como lenda. O primeiro que desembarcou imediatamente transformou-se em pó. Foi aí que se deram conta de que haviam se passado séculos em sua terra natal. Cf. Franco Jr., As Utopias medievais, 1992, p. 45-46; cf. também Elliott, The Shape of Utopia, p. 9.
} 
Histórias Verdadeiras de Luciano. Como em Panchéia, o fabuloso está ausente. Por mais longe que se afaste da Europa, Hitlodeu continua neste mundo enquanto atravessa oceanos, percorre reinos e vilas; por mais variações que sofram os costumes e os barcos, eles permanecem todos plausíveis. Os anos durante os quais ele ficou longe de casa se passaram da mesma forma e na mesma medida para os seus compatriotas portugueses.

E aqui encontramos o nosso segundo rei. É justamente o ato inaugural de Utopos, seu rei-fundador, que separa parte de um istmo para criar a ilha de Utopia, que determina a sua "localização" e o seu isolamento. Não é a chegada de Hitlodeu à ilha, mas é o corte efetuado pelo rei, que nos transporta verdadeiramente e nos faz saber que estamos num mundo apartado do conhecido.

Foi Utopos (cujo nome, na sequência de uma vitória alcançada, foi posto à ilha, pois antes dessa data o nome dela era $\mathrm{Abraxa}^{56}$ ) quem se empenhou em que um povo rude e selvagem chegasse a um grau de cultura e civilização que quase ultrapassa tudo aquilo que os outros mortais constituíram. Foi ele quem, logo depois de ter alcançado vitória fulminante a um primeiro e único ataque, tomou a peito rasgar um istmo, por onde a terra ficava ligada ao continente, e assim fez com que o mar circundasse o território. Para fazer tal obra requisitou não apenas indígenas (íncolas), mas (para eles não considerarem que o trabalho era forma degradante) associou-lhes também todos os seus soldados e por isso, com a repartição do trabalho por tanta gente, a obra foi realizada com uma rapidez inacreditável; aos vizinhos (que no início se riam por considerarem que era desvario) cativou-os pela admiração e acabou com eles pelo terror ${ }^{57}$.

Utopia não é uma dádiva da natureza, é uma construção, um artifício. O seu ato inaugural é um trabalho árduo e coletivo, realizado pelo conjunto de seus habitantes. Apesar de ter sido um projeto pensado por um visionário, um rei filósofo como quer Marie Delcourt ${ }^{58}$, e a quem a ilha deve o nome, só foi possível pela cooperação de

\footnotetext{
${ }^{56}$ Abraxa, segundo a nota do tradutor português, significa "terra sobre a qual não se chove". No plural, se encontra também no Elogio da Loucura de Erasmo e é o símbolo do conhecimento perfeito. Cf. Vtopia, pg. 291, n. 4.

${ }^{57}$ Utopia, p. 112 ;Vtopia, p. 291-292.

${ }^{58}$ Cf. More, L'Utopie, 1987, pg. 138, nota.
} 
todos. Aquilo que parecia inacreditável ganha realidade e o espanto não mais se deve aos feitos de deuses ou à terra encantada, mas ao engenho humano.

Por conta deste ato e das características próprias da ilha, Luigi Firpo, na introdução da edição italiana, a aproximou de Atlântida. A história desta última é contada no diálogo Crítias de Platão. Também ela adquiriu sua estrutura pelo exercício da força. A ilha, situada no Atlântico, foi legada ao deus Poseidon por ocasião da partilha da Terra entre os deuses. Nela vivia Clito, uma mortal que desperta o desejo de Poseidon e com ele tem dez filhos. Para tornar a ilha mais segura e apropriada para Clito e seus filhos, Poseidon encapsula a parte central e opera arranjos especiais.

Existia ao longo de toda a ilha, em direção ao mar, uma planície central, a qual se diz que seria a mais bela de todas as planícies e com uma fertilidade considerável. Nesta planície havia ainda na parte central uma montanha, baixa em todos os pontos, que distava cinquenta estádios ${ }^{59}$ do mar.(...) Então, de modo a construir uma cerca segura, [Posídon] desfez num círculo o monte em que ela [Clito] habitava, e construiu à volta anéis de terra alternados com outros de mar, uns maiores, uns mais pequenos - dois de terra e três de mar, no total, torneados a partir do centro da ilha e equidistantes em todos os pontos, para que fosse inacessível aos homens; com efeito, naquela altura ainda nem havia naus nem se navegava. Foi o próprio Posídon que organizou o centro da ilha facilmente, pois era um deus -, fazendo surgir de debaixo da terra duas nascentes de água - uma quente, outra fria - que corriam de uma fonte e fez brotar da terra alimentos variados e suficientes ${ }^{60}$.

Mas, Christian Rivoletti mostra como esta aproximação pode ser feita apenas na aparência. Atlântida é obra de um deus, Poseidon, e está inserida em outro enquadramento, que contrasta fortemente com a obra de More:

Em Atlântida, os produtos da fadiga e do engenho humano estão completamente imersos num contexto sobrenatural e divino, no qual a característica maravilhosa da natureza facilita fortemente o trabalho do homem, quando não o substitui mesmo: estamos muito longe do equilibrado modelo construído por More, que aqui mostra uma interação medida entre a característica natural, de uma parte, e a sua prudente utilização através do saber e da técnica do homem, de outra. ${ }^{61}$

\footnotetext{
598.880 metros.

${ }^{60}$ Platão, Crítias, 2011, 113c-e, p. 230-231

${ }^{61}$ Rivoletti, "Scienza, sapere umanistico e tecnica nell'Utopia di Thomas Morus", p. 57.
} 
Utopos, portanto, não é Poseidon, e Utopia não é Atlântida. Seus duplos são outros, bem mais prosaicos. Na verdade, Henrique VIII e Utopos ocupam lugares simétricos na obra. O primeiro abre o primeiro livro, que põe em relevo a Inglaterra, e o segundo abre o segundo livro, que descreve a ilha de Utopia. A Inglaterra representa o atual, o aqui e o agora. A realidade incontornável, o mundo do negócio; Utopia algo entre o real e o possível, no meio de caminho entre o concreto e o abstrato. Enquanto a Inglaterra é objeto de crítica para Hitlodeu, Utopia se reveste de positividade.

Esta simetria compõe a estrutura fundamental do livro. A obra está dividida em duas partes, dois livros: o primeiro, exceto pela breve narrativa de More, é composto basicamente por diálogos que servem de introdução à segunda parte. O segundo livro, exceto pelo diálogo no final, é composto basicamente da descrição de Utopia.

O livro I começa com More contando as circunstâncias de sua viagem à Bruges e como de lá seguiu à Antuérpia, onde encontrou seu amigo em comum com Erasmo, Peter Giles. E é durante a sua estada em Antuérpia, que, por intermédio de Peter Giles, More é apresentado a Hitlodeu, que à primeira vista lhe pareceu tratar-se de um capitão de navio. Peter Giles faz uma apresentação entusiasmada de Hitlodeu, aproximando o marinheiro de Platão. Seguem então para a casa de More, onde entabulam uma conversa, a qual constitui o primeiro diálogo. Num primeiro momento, o diálogo aparentemente gira em torno das experiências de Hitlodeu nos diversos lugares que percorreu. A certa altura, porém, Peter Giles sugere a Hitlodeu que ele deveria compor a corte de um rei. A partir de então, inicia-se um debate em torno da conveniência de se tomar parte no conselho de um rei. Discordâncias entre More e Hitlodeu acerca das 
condições necessárias para que tal participação tivesse eficácia dão ensejo então à passagem para o livro II, em que será exposta a Utopia.

O livro II, por sua vez, constitui a maior parte da obra, começando pela descrição física de Utopia, a história de sua criação, e seguindo-se sua estrutura política, econômica e social. São expostos também seus costumes, práticas e traços culturais específicos. Ao final, retoma-se o diálogo do livro I com More, curiosamente, mantendo sua discordância com Hitlodeu, e manifestando seu desacordo quanto a certas práticas dos utopianos.

O livro, portanto, é uma estrutura composta, que alterna entre o diálogo e a narrativa. O diálogo, forma predominante no livro I, marca essencialmente o momento presente e o velho mundo, sobretudo a Inglaterra. A narrativa marca um outro mundo e o tempo transcorrido neste Novo Mundo.

O primeiro diálogo é entre Giles e More e tem a função de apresentar e caracterizar Hitlodeu. Este diálogo se passa quando More avista, na saída de Notre Dame $^{62}$ ao final de uma missa, Peter Giles conversando com um homem desconhecido. Trata-se exatamente de Hitlodeu, descrito inicialmente pelo próprio More nos seguintes termos: “(...) dava ares de uma idade que passaria de mediana, rosto tisnado, barba comprida, Albornoz descaído no ombro descontraidamente; pelo rosto e pelo trajar parecia-me ele ser um capitão de navio"63.

Num segundo momento, é Giles quem toma a iniciativa e fornece a medida mais adequada do homem com quem conversava.

\footnotetext{
${ }^{62}$ Segui a nomenclatura utilizada pela tradução inglesa. Na tradução da Calouste está designada como Igreja de Santa Maria. Em nota, em ambas as traduções informam que a igreja estava inacabada na época em que More este em Antuérpia.

${ }^{63}$ Utopia, pg. 48; Vtopia, pg. 229.
} 
Por sua parte, Peter, logo que deu por mim, vem ter comigo, saúda-me, leva-me um tudo-nada para o lado, quando intento corresponder, e diz-me:

- Vê-lo? (ao mesmo tempo apontava para aquele com quem o vira estar a conversar). Estava mesmo a preparar o levar daqui e ir ter contigo direitinho.

- Em atenção a ti, respondi eu, seria recebido com o maior prazer.

- Muito mais por atenção a ele, acentuou, se soubesses quem ele é. De facto, não há ninguém hoje em dia que possa descrever como ele o descobrimento (historiam) grandioso de homens e de terras desconhecidas, coisas que sei estares todo ansioso por ouvir.

- Então, disse eu, não me enganei nas minhas suspeitas. De facto, logo que reparei nele, de imediato percebi que se tratava de um capitão de navio. ${ }^{64}$

Aqui, a figura de Giles desempenha um papel fundamental. Ao mencioná-lo pela primeira vez no texto, More se refere a ele em termos que fornecem o enquadramento do diálogo que se segue, pois indicam que se trata de uma pessoa que deve ser levada a sério: Giles é sábio, virtuoso e extremamente culto. Além disso, é um amigo ideal, devotado e fiel, e cuja rara modéstia o leva a ter horror à dissimulação. Giles é, portanto, alguém em que podemos confiar, tanto por sua virtude, quanto por sua sabedoria.

A apresentação de Hitlodeu é, assim, atravessada pelo crivo da apreciação do amigo de More. É por conta deste que Hitlodeu seria muito bem-vindo à casa de More: "Ia levá-lo diretamente a você", diz Giles. "Seria recebido com o maior prazer", responde More, “em atenção a ti”. Ao que Giles imediatamente responde: "Muito mais em atenção a ele". Na apreciação de Giles, Hitlodeu é, por si próprio, uma figura de grande interesse e com a qual seria extremamente proveitoso conversar. Para apresentar as razões disto, ele procura inicialmente afastar a impressão de que Rafael seria um simples marinheiro. Por certo que ele é um marinheiro, mas não como Palinuro, o piloto de Enéias.

- Pois é, disse ele, enganaste-te rotundamente; é um navegador, sim; não como Palinuro, mas como Ulisses, melhor, como Platão. Na realidade, este Rafael, assim ele

\footnotetext{
${ }^{64}$ Utopia, pg. 48; Vtopia, pg. 229-230.
} 
se chama, com nome de família de Hitlodeu, é um bom conhecedor não só de latim, mas também do grego, muito melhor até (a esta língua se aplicou mais do que à de Roma, pois se entregou inteiramente ao conhecimento científico (philosophia), sabendo que, tirando algumas obras de Sêneca e de Cícero, pouco resta de importância nesse domínio em latim) (...). ${ }^{65}$

Assim, após a sua aproximação com Ulisses e Platão, o nome de Rafael Hitlodeu nos é apresentado. Ulisses, é bom lembrar, foi, por seu ardil, responsável pela vitória da Grécia sobre Tróia. Trata-se da imagem da inteligência prática, aparentada à Métis. ${ }^{66}$ É famosa a passagem em que, pela astúcia, escapa de ser devorado por Polifemo. "Como te chamas?" pergunta, Polifemo. "Meu nome é ninguém", responde, Ulisses. Truque que se revelou fatal para Polifemo ao ter sido cegado por Ulisses: "Ninguém me feriu", gritou em vão, enquanto o rei de Ítaca escapava.

No entanto, mais do que esta inteligência prática ${ }^{67}$, que por certo Hitlodeu possui e aperfeiçoou em suas viagens por tantas e quantas terras, tendo conseguido retornar são e salvo, Hitlodeu se aproxima de Platão. Ele conhece mais o grego que o latim, pois se

\footnotetext{
${ }^{65}$ Utopia, pgs. 48-50; Vtopia, pg. 230-232.

${ }^{66}$ Assim aparece Métis na Teogonia: "Zeus rei dos Deuses primeiro desposou Astúcia (Métis) mais sábia que os Deuses e os homens mortais. Mas quando ia parir a Deusa de olhos glaucos Atena, ele enganou suas entranhas com ardil, com palavras sedutoras, e engoliu-a ventre abaixo por conselhos de Terra (Gaia) e Céu constelado (Urano). Estes lho indicaram para que a honra de rei não tivesse em vez de Zeus outro dos Deuses perenes: era destino que ela gerasse filhos prudentes, primeiro a virgem de olhos glaucos Tritogênia, igual ao pai no furor e na prudente vontade, depois um filho Deus dos Deuses e homens dotado de soberbo coração. Mas Zeus engoliu-a ventre abaixo para que a Deusa lhe indicasse o bem e o mal.” (Teogonia, 885-900). Tão logo toma o poder, Zeus desposa Astúcia, a filha de Oceano, cuja capacidade de mudar de forma herdada de seu pai selou seu destino. Ao desafía-la a transmutar-se numa gota d'água, Zeus a abocanha, para incorporar seus predicados, tornando-se ele mesmo a própria Astúcia e parindo em seguida Atena. De modo que, como mostra Vernant, Métis se torna definitivamente una com o poder soberano e indispensável ao domínio dos Deuses e dos homens. Segundo ele, não há soberania sem Métis ("a astúcia, a capacidade de antecipar tudo o que irá acontecer, de não ser surpreendido, nem ser desorientado por coisa alguma, de jamais abrir o flanco para um ataque inesperado"). Não por acaso, na Ilíada e na Odisséia é Ulisses quem vai figurar como o mais astuto dos homens, garantindo o triunfo sobre os troianos e a sua própria sobrevivência. A este respeito, em Les ruses de l'intelligence: la Mètis des grecs, Vernant lembra que na Odisséia, IX, 406-408, "Ulisses triunfa sobre o ciclope 'pela astúcia, não pela força' dolôi oudè bièphin". E acrescenta: "Sobre o papel de Métis, o emprego de doloi nas lutas guerreiras, cf. Odisséia, III, 119-121: durante nove anos os gregos enredaram seus inimigos em uma rede de embustes de toda sorte pantoioisi doloisi; mas ninguém se igualava em mètis a Ulisses que superava a todos em pantoioisi doloisi. Na Ilíada, III, 202, o polumètis, Ulisses conhecia pantoious te dolous kai mèdea pukna astúcias de toda sorte e densos pensamentos" Cf. Vernant, Oeuvres, pgs. 35-36 e 988, n 1.

67 "Como a alusão a suas viagens nos informa, a carreira de Hitlodeu reflete o humanista ideal, combinando contemplação com experiência prática". Cf. Logan, The meaning of More's Utopia, p. 34.
} 
consagrou ao estudo da Filosofia. Esta informação, que a princípio é um detalhe, na verdade é bastante significativa para compor o ethos da personagem. Esta aproximação com os "gregos", reiterando o vínculo do conhecimento do grego com o estudo da filosofia, é uma referência à polêmica entre os erasmianos, apelidados de "gregos", e alguns acadêmicos de Oxford, autodenominados "troianos".

Recentemente eu tenho ouvido relatos de um bom número de pessoas em Londres que certos acadêmicos em sua universidade, levados seja pelo ódio do aprendizado do grego, seja por uma mal orientada devoção por alguma outro coisa, ou (como acho mais provável) por uma desavergonhada obsessão pela zombaria e pela frivolidade, formaram uma conspiração deliberada para chamar a si mesmos de troianos. Um deles, que dizem ser mais maduro em anos do que em sabedoria, assumiu o nome de "Príamo", outro o nome de "Heitor", outro o nome de "Paris" ou então o de algum outro troiano, e o restante tem feito o mesmo, com o único propósito de se colocarem jocosamente como uma facção oposta aos gregos para ridicularizar os estudantes de grego... [Um destes "troianos"] chamou abertamente de heréticos todos aqueles que quisessem buscar o aprendizado do grego, e chegou a rotular os professores de grego de arquidemônios, e os estudantes de grego (...) como "subdemônios". 68

O conjunto de intelectuais próximos de Erasmo tinha entre os seus traços característicos a valorização da cultura e da filosofia gregas. "Há séculos era o latim que triunfava na universidade. A educação, fundada em textos de caráter religioso, tinha um objetivo moral acima de tudo. Mesmo Aristóteles, esse pilar da escolástica, era lido e discutido em latim e não na língua grega original." ${ }^{\text {"9 }}$ Mas em Oxford foram admitidos naquele período alguns humanistas, tais como Wiliam Grocyn, John Colet e Thomas Linacre, versados no conhecimento do grego e que inauguraram uma nova abordagem no estudo dos textos, inclusive dos textos sagrados $^{70}$. O grego passou a ser visto com desconfiança por alguns dos acadêmicos mais conservadores, julgado demasiado laico.

\footnotetext{
${ }^{68}$ Apud Nelson, The Greek Tradition in Republican Thought, 2004, pg. 25.

${ }^{69}$ Phélippeau, "Thomas Morus e a abertura humanista", p. 165.

70 "Foi provavelmente em no primeiro semestre letivo [Michaelmas Term] de 1946 que o anuncio foi feito para os doutores e estudantes da Universidade de Oxford que John Colet, um antigo estudante, recém-chegado da Itália, iria ministrar um curso com aulas públicas e gratuitas expondo as Epistolas de São Paulo". Seebohm, The Oxford Reformers: John Colet, Erasmus, and Thomas More, 1869.
} 
More entra na polêmica escrevendo esta longa carta, endereçada aos reverendos de

Oxford, que é considerada uma veemente defesa do grego e do humanismo erasmiano.

Voltemo-nos agora para a questão da educação humanista julgada laica. Ninguém jamais afirmou que um homem tenha necessidade de grego ou latim, ou, na verdade, de qualquer tipo de educação, para encontrar a salvação. No entanto, esse ensinamento que se qualifica de secular leva a alma à virtude. ${ }^{71}(\ldots)$

Eu não desejo de modo algum me colocar como o único defensor da aprendizagem do grego; pois sei quanto deve parecer evidente para os eruditos de Vossa Eminência que o grego é bom e verdadeiro. Àqueles para quem isso não seria evidente, digamos que devemos ao grego toda a precisão das artes liberais em geral e da teologia em particular, pois os gregos ou fizeram grandes descobertas eles mesmos, ou legaram-nas em herança em seguida. Tome a filosofia, por exemplo. Se você deixar de lado Cícero e Sêneca, os romanos escreveram sua filosofia em grego ou traduziram-na do grego. ${ }^{72}$

A carta fala por si. E é nela que temos também a pista da menção a Cícero e a Sêneca na caracterização de Hitlodeu, únicos dentre os romanos que foram verdadeiramente filósofos. Hitlodeu é assim colocado deliberadamente ao lado de Erasmo na controvérsia.

O segundo diálogo do livro I inaugura efetivamente a participação ativa de Hitlodeu. Agora o personagem é convidado a dialogar e a narrar suas experiências. Para isso é preparado um lugar adequado aos personagens e ao assunto abordado, e, conforme a tradição clássica retomada pelos humanistas, o lugar adequado será um locus amoenus: "[v]olto-me para Rafael e, depois de nos saudarmos e de trocarmos conhecimentos, como é habitual nessas circunstâncias, pomo-nos a caminho para minha casa e aí, no jardim, sentados num banco formado com um tufo de relva, ficamos a

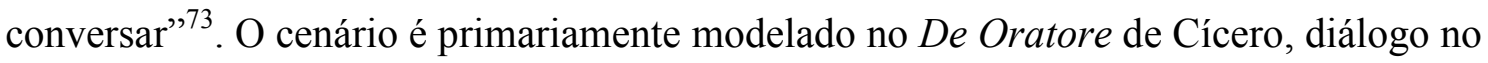
qual os homens virtuosos, sentados num jardim, debatem sobre os assuntos da mais alta

\footnotetext{
${ }^{71}$ Carta 19 "To Oxford University”. In: More, Selected Letters, p. 98-99. Apud Phélippeau, "Thomas Morus e a abertura humanista", 2013, p. 165-166.

72 Carta 19 "To Oxford University”. In: More, Selected Letters, p. 100. Apud Phélippeau, “Thomas Morus e a abertura humanista", 2013, p. 166.

${ }^{73}$ Utopia, pg. 50; Vtopia, 233.
} 
importância. Cícero, por sua vez, já evocava o Fedro de Platão ${ }^{74}$, como um indicativo do que seria tratado. Para melhor compreender de que modo o lugar de interlocução não é um mero acessório para a interpretação do significado do diálogo, recorremos ao artigo "a cidade perfeita e a ficção do conselho" de Ricardo Shibata:

(...) como rezam os ditames da poética quinhentista, qualquer tópica só pode ser corretamente interpretada se levarmos em conta o fato de ela constituir-se em elemento primário do, por assim dizer, "horizonte de expectativa" do leitor em relação a um gênero literário específico. Isto é, a enunciação da tópica determina o conjunto de significados possíveis a serem desvelados pelo discurso (...). Não é à toa que este aspecto da descrição espacial no diálogo quinhentista costuma desenvolver-se quando os interlocutores gozam de ócio (otium), estando livres de suas ocupações políticas, o que significa estar distante do barulho da multidão e das demandas da vida ativa.(...) Assim, retirar-se da vida ativa para o tempo de ócio é o descanso periódico de homens ilustres e moralmente virtuosos para manter a dignidade - melhor adequar-se às tarefas públicas e melhor executá-las (otium cum dignitate). O bom uso do tempo, na acepção estoica de Cícero e Sêneca, autores reativados no Renascimento, está atrelado ao distanciamento da degradação moral do vulgo e ao esforço do aprimoramento da virtude em si mesmo. Então, o encontro de homens virtuosos gastando bem seu tempo em lugar ameno corrobora o tema do debate sobre questões de índole cívica, uma vez que não há virtude que não seja virtude pública - o que rivaliza com certas interpretações que remetem o ócio ao conceito de "lazer" ou mero "passatempo". 75

Mas há um aspecto que chama atenção neste jardim descrito por More: a sua

simplicidade: somente um banco relvado, nada mais. Longe das almofadas e do plátano,

a dignidade retorna à simplicidade. Se mais do que moldura, como sustenta Shibata, o

locus é argumento, então a paisagem concorda com o que será narrado.

I. O Diálogo entre Giles, Hitlodeu e More

\footnotetext{
74 "No dia seguinte, quando os mais idosos já haviam repousado bastante, saímos para um passeio; então, após dois ou três vaivens: 'Por que, Crassus, diz Scévola não façamos como no Fedro de Platão? Eis um Plátano, do qual os galhos não espalham nenhuma sombra menos espessa que aquele sob o qual eu ouvi Sócrates, do qual a beleza era devida, menos ao riacho, de que fala o autor, do que a eloqüência de Platão. Se Sócrates, do qual a planta dos pés era tão calosa, se deixa cair sobre a grama para tratar os divinos assuntos que nos relatam os filósofos, com mais razão, eu que tenho os pés mais macios, posso fazer como ele'. Crassus: 'Que seja! Mas nós nos instalaremos mais comodamente. Ele pede almofadas e todos e todos tomam lugar sob o plátano"” (grifo meu). Cícero, De L’Orateur, 1934, p. 15.

${ }^{75}$ Shibata, R. "A cidade perfeita e a ficção do conselho: o livro I”, pg. 70.
} 
Logo em seguida, não sem antes fazer um sumário de algumas das viagens de que Hitlodeu lhe contou, More indica quais aspectos ele e também Giles estavam ávidos para ouvir: "aquelas coisas que se relacionam com a rectidão e o bom senso (recte prudenterque prouisa), que ele advertiu terem-se alguma vez arreigado entre povos que vivem em paz e de modo civilizado"76. E completa: “(...) perguntávamos com muito interesse sobre tais coisas e ele de muito bom grado nos ia respondendo (...)",77. Em seguida More toma o cuidado de afastar qualquer confusão a respeito do propósito da conversa, uma vez que se trata de um relato de viagem:

(...) passando de lado (omissa), no entanto, a questão dos monstros, sobre os quais nada há que traga alguma novidade. De facto, Cilas e Celenos vorazes, Lestrigones antropófagos e portentos imanes do mesmo jaez, não há quase nenhum lugar onde não se encontrem, mas cidadãos a viverem de forma sensata e ponderada é que não se encontram em parte alguma. ${ }^{78}$

More não estava interessado nas maravilhas contadas pelos viajantes. Monstros assustadores eram demasiado banais. Esta brincadeira com Lestrigões e Cilas nos dá a medida da novidade do livro. Cabe se voltar para os homens, suas instituições, costumes e o modo como ordenam seus Estados.

\begin{abstract}
Aliás, tal como Rafael reconheceu entre os povos do Novo Mundo comportamentos condenáveis, assim também não foram poucos os que registrou a partir dos quais se poderiam retirar lições idôneas para corrigir abusos nas cidades, nações, povos e reinos. Noutro lugar, como já acentuei, serão eles evocados.
\end{abstract}

\footnotetext{
76 "Quid quoque in loco se uidisse narrauit, et longum fuerit explicare, neque huius est operis institutum, et alio fortasse loco dicetur a nobis, praesertim quicquid ex usu fuerit non ignorari, qualia sunt in primis ea, quae apud populos usquam ciuiliter conuiuentes animaduertit, recte prudenterque prouisa" Utopia, pg. 52; Vtopia, pg. 237. (grifo meu)

77 "His enim de rebus et nos auidissime rogabamus, et ille libentissime disserebat, omissa ínterim inquisitione monstrorum, quibus nihil est minus nouum." Utopia, pg. 52; Vtopia, pg. 237. (grifo meu)

78 "Nam Scyllas \& Celenos rapaces, et Lestrigonas populiuoros, atque eiuscemodi immania portenta, nusquam fere non inuenias, at sane ac sapienter institutos ciues haud reperias ubilibet." Utopia, pg. 52; Vtopia, pg. 237.
} 
De momento é minha intenção referir apenas o que contava sobre os costumes e as instituições da Utopia, pondo à cabeça, aliás, aquele relato em que, por uma espécie de encadeamento, se chegou a falar da sua forma de governação (reipublicae). ${ }^{79}$

Assim, ele apresenta aquilo que já estava indicado desde o início (na figura do rei, nos negócios, nos ethos de Giles e Hitlodeu, no jardim, etc.) e foi cuidadosamente construído ao longo do primeiro livro. O livro trata dos costumes e instituições de Utopia, que se inscrevem num quadro mais amplo de interesse, a saber: as instituições idôneas das quais se podem retirar lições com intuito de "corrigir os erros que se cometem nas cidades, nações, povos e reinos".

More, tendo situado o leitor a respeito do eixo central da conversa, o diálogo prossegue com a pergunta que Giles dirige ao admirável e prudentíssimo Hitlodeu: ${ }^{80}$

Rafael, de facto, tinha já referido, com grande ponderação (prudentissime), alguns erros cometidos, ora aqui ora ali, muitos deles em ambos os lados, bem como aquilo que entre nós ou aquilo que entre eles constitui decisão avisada, ou também quais os costumes e as instituições que cada povo respeita, como se tivesse passado longo tempo em cada povo, quase parecendo que aí tivesse vivido sempre, pelo que Peter, admirado pelo seu à-vontade, lhe diz:

- Estou deveras admirado, caro Rafael, como não te colocas ao serviço de algum rei, pois, nenhum haveria, estou certo disso, por quem não fosses altamente apreciado, já que alguém com o teu saber, com a tua experiência e com teus conhecimentos dos países e das pessoas, não só é companhia agradável (oblectare) como também ensina pelo exemplo, e por ti és pessoa idônea para ajudar aconselhando e do mesmo modo para prover aos teus interesses em modo admirável e poderes contribuir com ajuda enorme a todos os vossos ${ }^{81}$.

\footnotetext{
79 "Ceterum ut multa apud nouos illos populos adnotauit perperam consulta, sic haud pauca recensuit, unde possint exempla sumi corrigendis harum urbium, nationum, gentium, ac regnorum erroribus idônea, alio, ut dixit, loco a me commemoranda.

Nunc ea tantum referre animus est, quae de moribus atque institutis narrabat Vtopiensium, praemisso tamen eo sermone, quo uelut tractu quodam ad eius mentionem reipublicae deuentum est." Utopia, pg. 52-54; Vtopia, pg. 237-238.

${ }^{80}$ Aqui se inicia o chamado "diálogo do conselho", trecho no qual se discute a pertinência de se participar de conselho de reis.

81 "Nam cum Raphael prudentissime recensuisset, alia hic, alia illic errata, utrobique certe plurima, tum quae apud nos, quaeue item sunt apud illos cauta sapientius, cum uniuscuiusque populi mores atque instituta sic teneret, tamquam in quemcumque locum diuertisset, totam ibi uitam uixisse uideretur, admiratus hominem miror Petrus, profecto mi Raphael, inquit, cur te regi cuipiam non adiungas, quorum neminem esse satis scio, cui tu non sis futurus uehementer gratus, utpote quem ac doctrina, atque hac locorum hominumque peritia non oblectare solum, sed exemplis quoque instruere, atque adiuuare consilio
} 
Ao argumentar em favor da participação de Rafael num conselho de rei, Giles acaba por revelar em que consistiria o papel do filósofo na corte: por conta de sua idoneidade e de seu saber, poderia aconselhar e instruir por meio de exemplos, de modo que a sua utilidade nos negócios públicos decorreria da honestidade, do conhecimento e da experiência. Como argumento suplementar, ele estende a utilidade para o âmbito privado, apresentando-a como uma espécie de bônus adicional. "e do mesmo modo para prover aos teus interesses em modo admirável e poderes contribuir com ajuda enorme a todos os vossos". Hitlodeu, no entanto, se aterá a este último aspecto da utilidade, ou seja, o do âmbito privado, entendida como recompensa pelos serviços prestados ao rei, que ele identifica à servidão ${ }^{82}$. A diferença é unicamente de sílaba ${ }^{83}$, diz ele. E, diante

sis idoneus, simul hoc pacto et tuis rebus egregie consulueris, et tuorum omnium commodis magno esse adiumento possis." Utopia, pg. 54; Vtopia, pg. 238.

${ }^{82}$ No original a palavra utilizada é seruitium, que o filólogo Aires Nascimento da edição Calouste traduz por "serviço", opção também do tradutor da recente edição brasileira da autêntica. A edição de Yale entretanto opta por "servitude", o que parece fazer mais sentido na sequência do diálogo. Reproduzo o trecho nesta nota e nas seguintes as falas que lhe sucedem: "Quod ad meos attinet, inquit ille, non ualde commoueor, nempe in quos mediocriter opinor me officii mei pates impleuisse. Nam quibus rebus alii non nisi senes et aegri cedunt, immo tum quoque aegre cedunt, cum amplius retinere non possunt, eas res ego non sanus modo ac uegetus, sed iuuenis quoque cognatis, amicisque dispartiui, quos debere puto hac mea esse benignitate contentos, neque id exigere atque expectare praeterea, ut memet eorum causa regibus in seruitium dedam."[No que diz respeito aos meus, respondeu ele, não me preocupo demasiado, já que quanto a eles considero que cumpri razoavelmente o que me competia. Na verdade, alguns apenas legam os seus bens quando já velhos ou doentes, e mesmo então não fazem sem ser a contragosto, quando já não são capazes de os administrar. Eu, pela minha parte, distribui essas coisas por parentes e amigos não apenas quando tinha ainda saúde e estava no vigor da idade, mas em plena juventude. Julgo que eles devem ter ficado satisfeitos com a minha liberalidade e por isso não esperarão que eu, por sua causa, me ponha ao serviço de reis.] Utopia, pg. 54; Vtopia, pgs. 238-239.

${ }^{83}$ Nesta resposta de Hitlodeu ao reparo de Giles ao uso do termo "seruitium", optamos por não seguir a tradução portuguesa. Nela o tradutor, procurando ser fiel ao significado da fala de Giles, embora tenha mantido a sonoridade da repetição das primeiras sílabas (serviço/servir/secundar), se afasta do jogo de palavras produzido pela paronomásia (seruitium/seruias/inseruias), que as vincula mais fortemente, como bem demonstrou Ana Cláudia Ribeiro. Em nota, Aires justifica a sua opção da seguinte maneira: "Os termos latinos são seruire ('ser escravo de', 'estar sujeito a') e inseruire ('estar ao serviço de'); não encontramos termos em português cuja forma, variando apenas de prefixo, corresponda aos valores em jogo, mas modalizamos o sentido". Esta opção do tradutor o obriga a encontrar uma solução que acaba por tornar a resposta de Hitlodeu demasiado suave. Porém, a força expressiva da fala de Hitlodeu está justamente na proximidade sonora das palavras de mesma origem. Giles sutilmente as distingue, Hitlodeu reaproxima: "Bona uerba inquit Petrus, mihi uisum est non ut seruias regibus, sed ut inseruias." [Palavras certas, diz Peter; a mim quer-me-ia parecer não que deverias servir às suas ordens, mas secundálas.] "Hoc est inquit ille, uma syllaba plusquam seruias" [- A diferença não é muita, ao menos nos termos, respondeu ele.] (grifo meu). Neste caso, a edição de Yale foi mais feliz: “'Fine words!'declared 
da insistência de Giles, ao afirmar que por esta via poderia ser útil aos negócios públicos e privados e ainda tornaria sua própria condição mais feliz, Hitlodeu responde: "Mais feliz (...) por um caminho que repugna meu espírito? Facto é que agora vivo como quero, coisa que suspeito aconteça a pouquíssimas pessoas que se vestem de púrpura" ${ }^{84}$, colocando a questão em termos da liberdade do otium em oposição à servidão do negotium. ${ }^{85}$

Deste diálogo sai fortalecida a figura de Hitlodeu. A imagem inicial do marinheiro de barbas longas e tez escurecida pelo sol adquire uma nova camada de significado $^{86}$. Ele é a imagem do saber desinteressado e, aqui, evoca a figura de Sócrates, o qual também tinha se furtado ao envolvimento com os assuntos públicos na esfera da política. Além disso, Rafael havia legado todos os seus bens a seus parentes e não está interessado em adquirir mais, tampouco aspira ao poder. Sua atitude o torna coerente com o elogio que faz de Utopia, república que tem como modelo. No seu âmbito privado, Hitlodeu vive de acordo com os valores da república ideal ${ }^{87}$.

Peter. 'I meant not that you should be in servitude but in service to kings. 'The one is only one syllable less than the other', he observed."'. A este respeito vale a pena conferir o artigo "Traduzindo os recursos sonoros do Livro I da Utopia para o português do Brasil" de Ana Cláudia Ribeiro, no qual ela não somente analisa e compara as diferentes traduções deste trecho, mas discute a musicalidade do texto latim moreano na Utopia.

${ }^{84}$ Utopia, pg. 54-56; Vtopia, pg. 239 (tradução modificada).O tradutor português utilizou a palavra "melhorar" para traduzir "feliciorem") "Felicioremne inquit Raphael, ea uia facerem, a qua abhorret animus! Atqui nunc sic uiuo ut uolo, quod ego certe suspicor paucissimis purpuratorum contingere."

${ }^{85}$ Esta oposição é posta mais claramente um pouco mais adiante na resposta de Hitlodeu a More.

${ }^{86}$ É possível que, na composição da imagem de Hitlodeu, More tenha incorporado elementos do diálogo "O Cínico" de Luciano (traduzido do grego para o latim por ele e Erasmo). O capote e a barba longa da personagem lembram em parte a caracterização do filósofo cínico, interlocutor de Luciano: “- Luciano: Você aí! Por que raios você usa barba e cabelos compridos, mas não camisa? Por que você expõe seu corpo e anda descalço, adotando por escolha esta vida nômade, antissocial e bestial? Por que, diferente de todos os outros, você abusa de seu corpo, infligindo-lhe sempre aquilo de que ele menos gosta, perambulando e pronto para dormir em qualquer lugar, no chão duro, de modo que o seu velho capote carrega uma grande quantidade de sujeira, embora nunca tenha sido fino ou macio ou florido? Cf. More, Thomas, Translations of Lucian. In: Thompson, Craig R. Complete Works of St. Thomas More, vol. 3, parte I, pgs 11 e 159.

${ }^{87}$ Para uma interpretação distinta, cf. Neumann, Harry, "On The Platonism of More's 'Utopia", Social Research, pgs. 497-498. Segundo este autor, é na medida em que encarna os valores da cidade imaginária que Hitlodeu é criticado no livro de More. A recusa de entrar para o conselho de um rei, bem como sua alegação de que teria distribuído os seus bens entre seus familiares, seria indício de sua pouca 
Ate então, o diálogo se dá entre Giles e Hitlodeu. É neste momento que More intervém. E o faz, em primeiro lugar reconhecendo o caráter e o valor de Rafael como um verdadeiro filósofo, mas também modificando os termos da questão. O debate retoma o enquadramento filosófico clássico nos termos do par utilitas/honestas, que já estava virtualmente contido na argumentação de Giles. Mas como More o faz? Ele busca compatibilizar a filosofia, como saber desinteressado, à vida pública.

- Interrompi então eu, é bem evidente, meu caro Rafael, que não andas em busca de riquezas nem de poder; pela minha parte, não é isso que me leva a ter menos respeito e consideração por alguém que seja do teu pensar para o pôr abaixo de alguém que exerça o poder mais elevado. Independentemente disso, parece-me que agirias de maneira bem de acordo contigo e com as tuas qualidades de espírito nobre (animo tuo tam generoso) ou também em harmonia com um verdadeiro homem de saber (uere philosopho) se, mesmo que com algum sacrifício pessoal, admitisses colocar as tuas qualidades (ingenium) e a tua atividade (industriam) ao serviço da colectividade (publicis rebus), já que nunca há tanta possibilidade de render como quando se faz parte do conselho de algum príncipe poderoso e o persuade de forma reta e honesta. (como sei que não deixarias de fazer). ${ }^{88}$

Hitlodeu discorda dos dois principais pontos da argumentação de More: o elogio de sua sabedoria e a possibilidade de verdadeiramente influenciar nos negócios do Estado. E é neste momento que se chega a uma parte fundamental da obra, a saber: o diálogo na casa do Cardeal Morton. Este diálogo faz parte da resposta de Hitlodeu à questão posta por More e versa sobre um problema central para a república, o da justiça. Ademais, ele também estabelece as bases para a introdução do relato sobre Utopia.

consideração pelos laços de parentesco e amizade ("the claims of blood and friendship apparently cease when one makes a free distribution of one's goods. The feeling for family ties and friendships implicit in this attitude is lukewarm to say the least").

88 "Tum ego, perspicuum est inquam te mi Raphael, neque opum esse, neque potentiae cupidum, atque ego profecto huius tuae mentis hominem non minus ueneror ac suspicio, quam eorum quemuis, qui maxime rerum sunt pontentes. Ceterum uideberis plane rem te atque isthoc animo tuo tam generoso, tam uere philosopho dignam facturus, si te ita compares, ut uel cum aliquo priuatim incommodo ingenium tuum atque industriam, publicis rebus acommodes, quod numquam tanto cum fructu queas, quanto si aconsiliis fueris magno alicui principi, eique - quod te facturum certe scio - recta atque honesta persuaseris." Utopia, pg. 56; Vtopia, pg. 239-240. (tradução modificada) 
Antes, porém, há um longo elogio a Morton, que More põe na boca de Hitlodeu. Este elogio, ao mesmo tempo serve de passagem e introdução para o diálogo na casa do Cardeal, abrindo um hiato no diálogo anterior com Giles e More, deixado em suspenso. Neste retrato, o Cardeal é a própria imagem do conselheiro ideal e até mesmo, por assim dizer, do governante sábio. Homem sério e grave, cujas virtudes inspiram mais respeito do que medo. Alguém que valorizava a força de caráter e a presença de espírito, sabendo distingui-las da imprudência. O Cardeal, que também é Lorde Chanceler, é assim descrito como uma figura que encarna a dignidade do cargo que exerce.

II. O Diálogo na casa do Cardeal Morton: um diálogo dentro do diálogo 89

Para a compreensão deste trecho do texto, não se pode perder de vista a sua localização e o seu papel na economia da obra. Além de servir de apoio, atuando como um exemplo concreto para o debate anterior, ao corroborar o principal argumento de Hitlodeu sobre a inutilidade de se participar dos negócios públicos, ele também concentra a crítica à Inglaterra, tornando-a um negativo de Utopia.

Se este diálogo tem a função de corroborar o argumento de Hitlodeu a More, é preciso então conhecer os termos deste argumento. Por que exatamente não é possível contribuir para a República e não vale a pena o filósofo se perturbar com tais assuntos $?^{90}$

\footnotetext{
${ }^{89}$ O diálogo na casa do Cardeal Morton (Utopia, pgs. 58-84; Vtopia, pgs 241-265) é introduzido no interior do chamado Diálogo do Conselho (Utopia, pgs. 54-103; Vtopia, pgs. 238-282) como parte da argumentação de Hitlodeu em favor da sua recusa em se tornar conselheiro.

90 "Bis erras, inquit ille, mi More, primum in me, deinde in re ipsa. Nam neque mihi ea est facultas, quam tu tribuis, et si maxime esset, tamen cum otio meo negotium facesserem, pubicam rem nihil promoueam" [Estás a cometer um duplo erro, meu caro More, atalhou ele: um erro relativamente a mim, outro relativamente ao tema em si; efectivamente, não é verdade que em mim haja essa qualidade que me atribuis; e, mesmo que existisse em grau superior, por muito que sacrificasse meu tempo de ócio ao trabalho (negotium), em nada iria favorecer à governação (pubicam rem)] Utopia, pg. 56; Vtopia, pg. 240.
} 
Primeiro, porque os próprios príncipes, na sua maior parte, estão todos mais que comprazidamente ocupados em estratégias militares (coisa de que eu não tenho experiência nem desejo tê-la) e preferem-nas a acções de paz ou passam muito mais tempo a congeminar de que modo lícito ou ilícito, conseguiriam conquistar novos reinos do que a administrar bem os que lhes couberam. Em segundo lugar, porque, de todos aqueles que pertencem ao Conselho dos reis, não há ninguém que procure aconselharse, seja porque alguém é de verdade altamente competente, seja porque lhe parece que é tão competente que não lhe apetece confrontar-se com o conselho de outrem, a não ser dos que aplaudem as opiniões mais absurdas e vivem do parasitismo daqueles que procuram apenas ganhar para si as boas graças do príncipe com seu aplauso. (...) Acontece até que, se, num grupo em que uns estão em competição com outros ou que colocam suas opiniões acima de tudo, alguém apresenta algum facto que leu ter ocorrido noutros tempos ou que viu dar-se noutros locais, os que escutam procedem como se todo o juízo sobre os seus conhecimentos estivesse em causa e depois disso tivessem de considerá-los estultos se eles próprios não conseguissem descobrir alguma deficiência nas propostas alheias. Se lhes faltam argumentos, então refugiam-se nisto: era o que nossos antepassados já aceitavam, dizem, e oxalá nós os igualássemos em saber!". ${ }^{11}$

São, portanto, dois os motivos principais: o rei está mais interessado na guerra do que em bem governar, e os cortesãos são viciosos - estão mais preocupados em adular o rei e em parecer sábios diante dele e aos próprios olhos do que com os assuntos do Estado. Neste quadro, nem o príncipe nem os conselheiros estão realmente preocupados com o que é útil para o Estado, mas antes com o que é útil para si mesmos. Por este motivo, as discussões degeneram em disputas pessoais. Estes elementos, cujas conseqüências são danosas, como veremos, aparecem com um arranjo particular no diálogo que se segue.

Diferente do diálogo anterior, que se passa no continente, o diálogo na casa do Cardeal Morton se passa na Inglaterra e versa principalmente sobre a república inglesa.

\footnotetext{
91 "Primum enim principles ipsi plerique omnes militaribus studiis - quorum ego neque peritiam habeo, neque desidero - libentius occupantur, quam bonis pacis artibus, maiusque multo studium est, quibus modis per faz ac nefas noua sibi regna pariant, quam uti parta bene administrent. Praetera quicumque regibus a consilio sunt, eorum nemo est, qui non aut uere tantum sapit, ut non egeat, aut tantum sibi sapere uidetur, ut non libeat alterius probare consilium, nisi quod absurdissimis quibusque dictis assentiuntur et supparasitantur eorum, quos ut maxime apud principem gratiae, student assentatione demereri sibi. (...) Quod si quis in illo coetu uel alienis inuidentium, uel praeferentium sua, aliquid afferat, quod aut aliis temporibus factum legit, aut aliis fieri locis uidit, ibi qui audiunt, perinde agunt, ac si tota sapientiae suae periclitaretur opinio, et post illa pro stultis plane sint habendi, nisi aliquid sufficiant inuenire, quod in aliorum inuentis uertant uitio. Si Cetera destituant, tum huc confugiunt, haec nostris, inquiunt, placuere maioribus, quorum prudentiam utinam nos aequaremus, itaque hoc dicto ueluti egregie perorata re considunt." Utopia, pg. 56-58; Vtopia, pg. 240-241.
} 
Ele ocorre pouco depois da revolta de Cornwall, em 1497, portanto, em tese, antes de Hitlodeu acompanhar Américo Vespúcio em suas viagens. Os personagens deste diálogo são, além de alguns convivas não nomeados, o frade, o bufão, o leigo versado em leis, o próprio Hitlodeu e o Cardeal Morton ${ }^{92}$.

O diálogo se divide em duas partes, sendo a primeira em tom grave e segunda em tom jocoso: a) a primeira parte é aquela que tem a participação de Hitlodeu; b) a segunda parte é a discussão do bufão com o frade.

\section{Primeira parte: discussão grave}

A primeira parte, que é também a maior, se divide por sua vez em outras duas: a) o diálogo de Hitlodeu com o leigo versado em leis; b) o diálogo de Hitlodeu com o Cardeal.

\section{1. Diálogo de Hitlodeu com o leigo:}

Quis o acaso da sorte que, estando eu certo dia à sua [do Cardeal] mesa, se encontrasse nela também um homem secular (laicus), perito nas leis do vosso país (legum uestratium peritus); aproveitando não sei que oportunidade, pôs-se ele a elogiar com grande apuro o rigor da justiça que por essa altura se aplicava contra os ladrões, aos quais, uma ou outra vez, segundo contava, se penduravam, aos vinte, numa mesma forca $(\text { cruce })^{93}$; ora, dizia ele, o que mais o espantava era que, apesar de serem poucos os que

\footnotetext{
${ }^{92}$ O Cardeal Morton (1420-1500) é uma figura importante na biografia de Thomas More. Antes de tornarse Cardeal em 1493, foi nomeado Arcebispo de Canterbury em 1486 e no ano seguinte tornou-se também Lorde Chanceler da Inglaterra. Thomas More permaneceu dois anos em sua casa como pajem para aprender sobre os negócios de Estado.

${ }_{93}$ A tradução foi modificada. Aires Nascimento da edição Calouste traduziu o termo latino "cruce" por "cruz". Entretanto, para não dar margem a equívocos, utilizamos a tradução alternativa de forca, opção seguida por Edward Surtz e J.H. Hexter, editores de Yale, também por George Logan e Robert Adams da edição de Cambridge e por Márcio Gouvêa Júnior, tradutor da recente edição da Autêntica. Na nota 19, pg. 15 da edição de Cambridge há a seguinte referência: "Raphael Holinshed reports that, in the reign of Henry VIII alone, 72,000 thieves were hanged (Holinshed's Chronicles [of] England, Scotland, and Ireland, 6 vols. (1807; rpt New York, 1965), I, 314)"
} 
escapavam ao suplício, por uma fatalidade inexorável, acontecia que muitos continuavam a actuar daquela maneira, por toda parte. ${ }^{94}$

Hitlodeu introduz o diálogo de modo a apresentar o seu interlocutor ao mesmo tempo em que já nos coloca a par do assunto discutido por eles. O modo como o leigo é introduzido já apresenta um traço de ironia ("perito nas leis de vosso país") e indica alguma inconveniência de seu comportamento. Parece ficar sugerido aqui que o comentário feito por esta personagem foi um tanto gratuito e não fruto de alguma conversa que estava sendo desenvolvida (“aproveitando não sei que oportunidade”).

A ironia do epíteto ("perito") se confirma quando do espanto do tal conhecedor, que não sabia explicar por que os homens continuavam roubando apesar da rigidez da pena que lhes era aplicada. Hitlodeu toma a palavra e argumenta no sentido de demonstrar que uma pena muito rígida e não proporcional ao delito não é justa e nem útil. "Não vos admireis; de facto, tal punição dos ladrões ultrapassa as exigências da justiça e não serve o interesse público. Efectivamente, tal medida é demasiado cruel para tirar vingança dos roubos e não é suficiente para lhes pôr cobro." 95

A partir daí, Hitlodeu começa a introduzir a questão principal do diálogo, que é apontar os males que assolavam as repúblicas naquele período e, em seguida, o mal próprio da Inglaterra. Hitlodeu identifica nestes males a fonte das injustiças cometidas. De que modo ele começa a discutir a questão? Ele compara as repúblicas da época, incluindo a Inglaterra, a maus professores “que preferem castigar os alunos a ensinálos”. Embora o significado completo desta comparação só possa ser compreendido mais

\footnotetext{
94 "Forte fortuna cum die quodam in eius mensa essem, laicus quidam legum uestratium peritus aderat, is nescio unde nactus ocasionem, coepit accurate laudare, rigidam illam iustitiam, quae tum illic exercebatur in fures, quos passim narabat nonnumquam suspendi uiginti in uma cruce, atque eo uehementius dicebat se mirari, cum tam pauci elaberentur supplicio, quo malo fato fieret, UTI tam multi tamen ubique grassarentur". Utopia, pg. 58; Vtopia, 242.

95 "Nam haec punitio furum et supra iustum est, et non ex usu publico. Est enim ad uindicanda furta nimis atrox, nec tamen ad refrenanda sufficiens." Utopia, pg. 60; Vtopia, pgs. 243-244.
} 
concretamente no diálogo com o Cardeal Morton, neste momento, a comparação, a princípio, não parece se encaixar muito bem.

Por um lado, nem o roubo simples é realmente um delito assim tão desmedido que deva pagar com a pena capital nem, por outro lado, há pena que chegue para evitar que cometa latrocínios quem não tem qualquer meio de ganhar a vida. (...) $\mathrm{Na}$ realidade, condenam o ladrão a castigos pesados e até horrendos quando seria preferível providenciar a que houvesse algum modo de subsistência, de forma que ninguém tivesse que enfrentar, primeiro, a cruel necessidade de ter de roubar e, seguidamente, a inevitabilidade de perder a vida ${ }^{96}$.

Ora, assegurar as condições necessárias para que alguém não se torne um ladrão não é o mesmo que ensiná-lo. Mas, deixemos de lado, por enquanto, esta questão. $\mathrm{O}$ fato é que logo no início do diálogo, está posta a principal tese de Hitlodeu para a quantidade de roubos e para a ineficácia das penas aplicadas: as condições de vida não estão asseguradas, tornando o roubo ou a mendicância uma necessidade. A necessidade deve ser entendida aqui no sentido forte do termo, como algo que se impõe inexoravelmente. Quais os motivos que teriam levado a esta situação? Há uma explicação mais geral, que serve para toda a Europa, e há uma explicação específica para o caso da Inglaterra. A explicação que compreende toda a Europa tem uma estreita relação com a sua crítica às guerras e às cortes. Ambas seriam as fontes comuns de produção de pessoas sem encaixe social e viciosas. No que se refere às guerras, a preocupação é com os soldados, que voltam para casa mutilados, débeis e sem condições de exercer um novo ofício. Além disso, se habituaram ao exercício da violência e a um ofício que muito se assemelha ao dos ladrões. Quanto às cortes, a

\footnotetext{
96 "Quippe neque furtum simplex tam ingens facinus est, ut capite debeat plecti, neque ulla poena est tanta, ut ab latrociniis cohibeat eos, qui nullam aliam artem quaerendi uictus habent. (...) Decernuntur enim furanti grauia atque horrenda supplicia, cum potius multo fuerit prouidendum, uti aliquis esset prouentus uitae, ne cuiquam tam dira sit furandi primum, dehinc pereundi necessitas."Utopia, pg. 60 ; Vtopia, pg. 244.
} 
preocupação recai sobre a grande quantidade de nobres perdulários, que se cercam de parasitas acostumados à ociosidade e cheios de orgulho. Em ambos os casos, porém, o que se encontra são pessoas pouco afeitas à convivência social sadia e inaptas para o trabalho. É interessante notar que, neste argumento, os cortesãos que gravitam em torno da nobreza aparecem a esta altura não por seu papel como maus conselheiros, mas como aqueles que em algum momento conhecerão o patíbulo.

Há um grande número de fidalgos que não só passam a vida na ociosidade, como zangões atidos ao trabalho de outros, mas ainda por cima, para aumentarem seus rendimentos, sugam os seus trabalhadores até ao sangue vivo. É de facto a única frugalidade que conhecem, pois, quanto ao resto são tão esbanjadores que caem na mendicidade; de verdade, trazem à sua volta uma grande multidão de parasitas sem terem nada para fazer que nunca aprenderam qualquer ofício para ganhar a vida. Dê-se o caso de o seu patrão morrer ou de eles caírem doentes: imediatamente são postos fora, pois se prefere alimentar ociosos a dar de comer a doentes; bastas vezes o herdeiro de alguém que acaba de morrer não tem logo o suficiente para sustentar a clientela paterna, pelo que eles terão que passar fome deveras, a não ser que se ponham a roubar. De facto, que haveriam de fazer? ${ }^{97}$

A Inglaterra, porém, tem ainda nos cercamentos uma fonte suplementar de injustiças: "vossos carneiros (...) que são tão mansos e se costumam sustentar com tão pouca coisa, agora (ao que dizem) passaram a ser tão vorazes e indômitos que devoram até os homens, devastam e despovoam os campos, as casas, as povoações"98.

Hitlodeu se detém neste ponto e dá o espaço que o tema merece, expondo-o longamente, pois se trata de uma tragédia humanitária, embora ele não formule a questão nestes termos. Destaquemos alguns elementos de sua argumentação:

\footnotetext{
97 "Tantus est ergo nobilium numerus, qui non ipsi modo degant otiosi tamquam fuci laboribus aliorum, quos puta suorum praediorum colonos augendis reditibus ad uiuum usque radunt. Nam eam solam frugalitatem nouere, homines alioquin ad mendicitatem usque prodigi; uerum immensam quoque otiosorum stipatorum turbam circumferunt, qui nullam umquam quaerendi uictus artem didicere. Hi simul atque herus obierit, aut ipsi aegrotauerint, eiiciuntur ilico. Nam et otiosos libentius quam aegrotos alunt, et saepe morientis heres non protinus aleandae sufficit paternae familiae. Interim illi esuriunt strenue, nisi strenue latrocinentur. Nam quid faciant?"Utopia, pg. 62; Vtopia, pg. 245.

98 "Oues inquam uestrae, quaetam mites esse, tamque exiguo solent ali nunc (ut fertur) tam edaces atque indomitae esse coeperunt, ut homines deuorent ipsos, agros, domos, oppida uastent ac depopulentur."Utopia, pg. 64-66; Vtopia, pg. 248.
} 
Assim, seja a que título for, saem das suas terras, sem nada, homens, mulheres, maridos, esposas, órfãos, viúvas, pais com os filhos pequenos, uma família mais numerosa que remediada, pois a terra para ser cultivada precisa de muitos braços; saem, digo, dos lugares por eles conhecidos e a que se haviam acostumado, sem saberem onde se refugiar (...). Quando, a breve trecho da sua errância, já têm esgotado tudo, que lhes resta, por fim, senão roubar e ser enforcados pela justiça, ou vaguear e pôr-se a pedir? Embora então também os lancem na prisão como vagabundos que andam de um lado para outro sem trabalhar, não há ninguém que os contrate para isso, ainda que eles se ofereçam insistentemente. ${ }^{99}$

O tom de Hitlodeu é indignado e poético, procurando exprimir a terrível injustiça que estas pessoas estão sofrendo. Neste caso, diferente dos anteriores, não há nenhum vício nos costumes, nenhuma falha no caráter daqueles que acabam no cadafalso ou na prisão: “(...) não há ninguém que os contrate (...) ainda que eles se ofereçam insistentemente. $\mathrm{O}$ fato é que no trabalho dos campos, a que eles se haviam habituado, nada há a fazer, pois nada se semeia". Neste caso, eles não são ociosos, mas são forçados por outros, os verdadeiramente viciosos, à ociosidade. Assim, a injustiça que acontece na Inglaterra é ainda maior do que nos outros casos.

O leigo praticamente não fala. Quanto ele ameaça se pronunciar mais longamente em contraposição a Hitlodeu, o Cardeal interrompe para propor uma questão.

Não digas nada, interveio o Cardeal, pois não me parece que vás responder em poucas palavras se começas assim. Além do mais, dispensar-te-emos do incômodo de responder por agora, mas reservamos-te tal incumbência por inteiro da próxima vez que nos encontrarmos contigo, que gostaria que fosse já amanhã (a não ser que algo o impeça, da tua parte, ou da parte do nosso amigo Rafael). Contudo, entretanto, Rafael, gostaria

\footnotetext{
99 "Itaque quoquo pacto emigrant miseri, uiri, mulieres, mariti, uxores, orbi, uiduae, parentes cum paruis liberis, \& numerosa magis quam diuite família, ut multis opus habet, manibus res rústica, emigrant inquam e notis atque assuetis laribus, nec inueniunt quo se recipiat, suplellectilem omnem haud magno uendibilem, etiam si manere possit emptorem, quum extrudi necesse est, minimo uenundant. id quum breui errando insumpserint, quid restat aliud denique, quam ut furentur, \& pendeant iuste scilicet, aut uagentur atque mendicent. Quanquam tum quoque uelut errones conijciuntur in carcerem, quod ociosi obambulent, quorum operam nemo est qui conducat, quum illi cupidissime offerant."Utopia, pg. 66; Vtopia, pg. 249.
} 
de ouvir, da tua parte, por que é que tu consideras que o furto não deve ser castigado com pena capital ou que outra pena tu próprio estabelecerias que melhor conviesse ao bem público, pois nem tu serás de parecer que ele deva ser tolerado. Ora se hoje, mesmo com risco de condenação à morte, se cometem roubos, se não houver perigo de vida, que força ou que receio pode desencorajar os prevaricadores? Eles interpretarão que, mitigando o castigo, há uma espécie de prêmio e de convite ao crime... ${ }^{100}$

O leigo parece servir quase que inteiramente como suporte ${ }^{101}$ para o discurso de Hitlodeu. Discurso que neste momento da exposição, é na sua quase totalidade crítico, pois seu alvo principal são os erros das repúblicas, os quais ele coloca em evidência. $O$ único trecho que destoa do direcionamento crítico é o final, onde ele faz uma exortação no sentido de que fosse mudado o atual desenvolvimento das coisas na Inglaterra, a fim de se reverter os males causados pelos cercamentos. De qualquer forma, este é também um trecho importante, pois reforça as singularidades do caso da Inglaterra: enquanto soldados e cortesãos são fontes (e, ao mesmo tempo, objetos) universais de injustiça em todos os reinos, na Inglaterra a calamidade é provocada pelos cercamentos, uma novidade que implica numa ampliação desta mesma injustiça.

O problema dos cercamentos não estava posto no diálogo com Giles e More. De que maneira ele se relaciona com o diálogo anterior? Mais do que isso, de que modo o que foi dito até aqui mostra a inutilidade da participação do filósofo na vida ativa?

\subsection{Diálogo de Hitlodeu com o Cardeal Morton:}

O diálogo com o Cardeal Morton tem um caráter mais jurídico e se reveste de positividade, na medida em que não é unicamente crítico. O seu objeto é a pena adequada ao delito.

\footnotetext{
${ }^{100}$ Utopia, pg. 70; Vtopia, pg. 253.

${ }^{101} \mathrm{Na}$ verdade, o leigo cumpre ainda outro papel, mas trataremos disso mais adiante.
} 
A pergunta do Cardeal tem dois momentos e, em atenção a ela, Hitlodeu primeiramente apresenta as razões pelas quais a pena de morte é injusta, e em segundo lugar, ele propõe modelos, extraídos de países estrangeiros, que poderiam servir de alternativa para sanar os erros cometidos.

A injustiça da pena de morte consiste em primeiro lugar na sua desproporção, afirma Hitlodeu, reiterando o argumento que já havia apresentado ao leigo, mas acrescentando ainda um aspecto que tem implicações mais amplas. "O meu parecer, benigníssimo Padre, é de que é inteiramente iníquo tirar a vida por se ter tirado dinheiro. De facto, considero que a vida humana não pode colocar-se em pé de igualdade nem sequer com o conjunto dos bens de fortuna que se possuam." ${ }^{102}$ Ao afirmar que a vida humana está acima dos bens da fortuna, Hitlodeu reordena a questão a partir de outra escala de valores. Na verdade, a questão da justiça é posta em termos filosóficos, uma vez que o que se tem em vista é o objetivo mesmo da república.

Em segundo lugar, a sua injustiça está no fato de transgredir a lei divina, já que os dez mandamentos proíbem o assassinato, e esta proibição não admite exceções. $\mathrm{O}$ "não matarás" não pode ser revogado por leis humanas. Fosse assim, também o seriam o adultério e o perjúrio.

Como modelo alternativo à pena de morte, Hitlodeu apresenta as punições praticadas em Roma ${ }^{103}$ e mais detidamente as adotadas pelos Polileritas ${ }^{104}$, consideradas melhores. Os Polileritas condenam os ladrões à escravidão e a restituir o bem subtraído, pois isto os tornaria mais úteis do que colocá-los a ferros. São forçados a trabalhar tanto

\footnotetext{
${ }^{102}$ Utopia, pg. 74; Vtopia, pgs. 253.

${ }^{103}$ Em Roma, afirma Hitlodeu, "os que eram tidos como culpados por grandes crimes eram condenados às pedreiras e a escavar nas minas de metais, presos a cadeias por toda a vida". Utopia, pg. 74; Vtopia, pg. 255-256.

${ }^{104}$ Polileritas significa povo de muitos nonsenses. O sistema penal dos Polileritas, exceto pela chibata e pela mutilação, se assemelha ao dos utopianos.
} 
para o Estado quanto para um particular, mas são proibidos de receber dinheiro por isso. A chibata substitui as algemas no caso dos mais preguiçosos. Já aqueles que cooperam, são tratados com humanidade. Para evitar sua fuga, portam um uniforme e têm uma parte da orelha cortada. Além disso, para evitar sedições, não podem se reunir e são proibidos de transpor os limites do distrito. Embora a pena seja perpétua, contudo há esperança, uma vez que podem ser perdoados por bom comportamento ou por denunciarem fugas, sedições ou quaisquer transgressões às penas impostas.

Ao término da exposição, quando Hitlodeu afirmou não ver razão "para que este procedimento não tivesse lugar mesmo na Inglaterra", o jurisconsulto, balançando a cabeça negativamente, redargüiu dizendo que "nunca tal prática se poderia estabelecer em Inglaterra sem fazer com que a república (rempublicam) corresse grandes perigos" $" 105$.

Foi então que o Cardeal disse que o sistema poderia ser testado, já que não seria possível saber de antemão se funcionaria na Inglaterra. E propôs que talvez fosse possível, uma vez proferida a sentença, suspender temporariamente a execução dos condenados e experimentar a aplicação deste novo regime. "Se, por seu lado, se comprovar que a medida tem efeitos positivos, será justo que se decida por ela"106, arremata o Cardeal, afirmando ainda que a proposta poderia ser estendida aos vadios. Os convivas, tendo antes aprovado o jurisconsulto, passam a aplaudir entusiasmadamente o Cardeal, sobretudo no que dizia respeito à solução para os vadios.

Feito este percurso, é possível reunir mais alguns elementos para análise. Somente neste trecho é possível discernir o que Hitlodeu tinha em mente quando utilizou a metáfora do mau professor. A comparação é diferente do que se poderia supor

\footnotetext{
${ }^{105}$ Utopia, pg. 78-80; Vtopia, pg. 260 (tradução modificada).

${ }^{106}$ Utopia, pg. 80; Vtopia, pgs. 260.
} 
a princípio. O mau professor faz o aluno sofrer duas vezes - na primeira, por não ensiná-lo; na segunda, ao castigá-lo por ignorar aquilo que não lhe foi ensinado. Analogamente, a república inglesa inflige um duplo sofrimento aos miseráveis que sobem ao cadafalso - inicialmente, ao privá-los dos meios de vida; em seguida, ao condená-los à morte por recorrerem ao roubo na tentativa de sobreviver. Os Polileritas (o povo de muitos nonsenses), por outro lado, puseram em prática um sistema em que é possível ensinar em vez de somente espancar.

2. Segunda parte: a discussão entre o bufão e o frade ${ }^{107}$

Por um instante, Hitlodeu reluta entre contar ou não esta segunda história, a qual ele qualifica como ridícula. Por fim, acaba se resolvendo a contar, porque, diz ele, "tem algo que ver com o nosso tema" ${ }^{\text {"108 }}$. A discussão é pontuada por manifestações dos convivas anônimos entre aplausos e expectativas pela reação do Cardeal.

O bufão é descrito por Hitlodeu como "um daqueles parasitas que gostam de fazer de bobo de imitação, mas que era tão mal imitador que, sendo falho de chama no que dizia, geralmente o riso vinha mais da sua figura que das suas palavras." ${ }^{109}$ Um dos convivas lembrou que o Cardeal e Hitlodeu haviam atendido a sorte dos vagabundos e ladrões, mas que "restava agora saber como cuidar a expensas públicas daqueles que a

\footnotetext{
${ }^{107}$ Nas notas marginais (de autoria controversa, já que não se sabe se foi Giles ou Erasmo que as introduziu) este trecho está identificado como "Festivus dialogus fratris \& morionis", traduzido na edição de Yale como "A Merry Dialogue between a Friar and a Hanger-On". Na tradução da Calouste foram suprimidas as notas marginais. Utopia, pg. 80-81.

${ }^{108}$ Utopia, pg. 80; Vtopia, pg. 261

${ }^{109}$ Utopia, pg. 80; Vtopia, pg. 261.
} 
doença ou a velhice tinham reduzido à miséria, por terem ficado incapacitados para os trabalhos que lhes permitissem viver" ${ }^{\prime 10}$.

O bufão se apressou a responder nos seguintes termos:

Deixem-me a mim, dizia, que eu providenciarei a que se tenha isso em conta. De facto é intenção minha bem firme arredar da minha vista, para qualquer parte, esse tipo de indivíduos: já-me indispuseram imensas vezes, choramingando a pedir dinheiro, mas nunca conseguiram cantar-me o fado a jeito para me extorquirem uma moeda. É verdade; sempre tem acontecido ou que não me apetece dar ou que não me é possível fazê-lo, porque nada tenho para dar. Assim começaram eles a perceber: para não perderem tempo, quando me veem passar, deixam-me seguir sem nada dizerem; assim já nada esperam de mim, nada mais, santo Deus, do que esperariam se eu fosse sacerdote. Ora, a todos esses mendigos com uma lei mandaria distribuí-los em grupos e encaminhá-los para mosteiros beneditinos onde se fizessem irmãos leigos, como lhes chamam. Quanto às mulheres, ordenaria que as fizessem monjas. ${ }^{111}$

A altercação começou quando o frade objetou que não se poderia acabar com a mendicância a menos que se quisesse acabar com os frades. O bufão então não se fez de rogado e emendou outra piada.

Disso já se tomou cuidado; o Cardeal tomou superiormente isso a seu cargo, quando previu medidas sobre os vagabundos que haviam de ser encarcerados e obrigados a trabalhar; é que vós sois vagabundos de primeiro grau. ${ }^{112}$

O frade, muito ofendido, começou a proferir anátemas e impropérios, chamandoo de hipócrita, difamador e filho da perdição. A discussão continuou até o Cardeal intervir e encerrar o jantar.

Hitlodeu chama a atenção para o fato de que, a cada fala do bufão, seguia-se a expectativa dos demais convivas quanto à reação do Cardeal. Uma vez que tal reação não era clara, e julgando eles que havia aprovação, aplaudiam o bufão e assim o

\footnotetext{
${ }^{110}$ Utopia, pg. 80; Vtopia, pg. 261-262.

${ }^{111}$ Utopia, pg. 80-82; Vtopia, pg. 262.

${ }^{112}$ Utopia, pg. 82; Vtopia, pg. 263.
} 
estimulavam a prosseguir. Nestes termos, os convivas são claramente caracterizados como um grupo de aduladores ${ }^{113}$.

Estas figuras ridículas são uma ampliação do que significa participar da corte. Quando o diálogo com More e Giles é retomado, Hitlodeu procura ampliar a caracterização feita acrescentando situações problemáticas que, no contexto do livro, são apresentadas como apenas hipotéticas, mas que se sabe que se referiam a casos reais (como, por exemplo, a manipulação do valor da moeda pelo rei), nos quais os conselhos corretos obviamente seriam recusados. More se contrapõe argumentando que em casos assim, torna-se necessário participar da comédia, buscando agir dentro das possibilidades. Hitlodeu, porém, recusa que esta possa ser uma solução aceitável e afirma que procedendo deste modo, "outra coisa não aconteceria senão que, ao procurar remediar a loucura de outros, eu próprio enlouqueceria" ${ }^{\text {"114 }}$.

No comportamento do leigo versado em leis, dos convivas aduladores, que só aplaudem o que imaginam que agradará o Cardeal, do bufão e do frade está o retrato das cortes e do conselho real. O leigo se comporta, na discussão de um tema grave, como se se tratasse de uma disputa pessoal. Ele reage como se sua reputação fosse ficar comprometida e procura por todos os meios demonstrar que há vícios na opinião de Hitlodeu. Ora, esta é exatamente a forma como Hitlodeu disse que os cortesãos reagiriam.

A discussão grotesca providencia o arremate ao mesmo tempo terrível e irônico da cena. O tolo parece não ter ouvido a descrição dramática de Hitlodeu ou simplesmente não se importou. O mesmo vale para todos os outros que estavam mais

\footnotetext{
${ }^{113}$ Segundo Robert Elliott, a altercação entre o bufão e o frade é moldada a partir de uma sátira de Horácio (1.7) na qual um comerciante grego e um romano tolo e venenoso discutem. A fórmula podia ser encontrada também na sátira "A Jornada de Brundisium" em que Sarmento, o tolo, discute com Messius Cicirrus, o bufão. Elliott, The Shape of Utopia, p. 36.

${ }^{114}$ Utopia, pg. 100; Vtopia, pg. 279.
} 
preocupados com a própria imagem, nada mais. Entretanto, são eles os cortesãos ociosos, os parasitas, descritos pouco antes, e cujo destino fora anunciado.

A chave da compreensão deste trecho, portanto, não apenas está no que Hitlodeu diz, nos argumentos que mobiliza, mas também na forma como o diz. Algumas páginas depois, quando More volta a cena, Hitlodeu afirma: "Foi minha intenção tudo referir para que faças um juízo daqueles que, quando eu tinha a palavra, me censuravam (...). Oxalá, daqui possas julgar em quanto valor serão tidos os meus conselhos nas funções áulicas que me cabem". 115

Toda a maneira pela qual este trecho é construído, seu funcionamento, o modo como a situação é narrada e a caracterização das personagens permitem avançar o argumento, tudo isso constitui uma instância importante na qual se evidencia como a forma desempenha um papel central em Utopia. Utopia não é um tratado, ela se apresenta como uma obra poética. Mais ainda, é uma obra propositadamente equívoca em muitos de seus aspectos. Este traço foi bastante cultivado por More. Na carta a Giles, por exemplo, More diz:

Meu caro Peter, eu fiquei absolutamente deliciado com o julgamento daquele colega muito arguto, você se lembra, que colocou este dilema em relação à minha Utopia: se a história é oferecida como fato (diz ele) então eu vejo uma quantidade de absurdos nela; mas se é ficção, então eu acho que o costumeiro bom julgamento de More ficou a desejar em algumas matérias. (...) Mas quando ele questiona se o livro é fato ou ficção eu acho que o costumeiro bom julgamento dele ficou a desejar. Não nego que se tivesse decidido escrever sobre uma república, e um conto deste tipo tivesse vindo à minha mente, eu talvez não tivesse evitado uma ficção por meio da qual a verdade, como um medicamento misturado com mel, pudesse entrar na mente de um modo um pouco mais agradável. ${ }^{116}$

A ambigüidade perpassa todo o livro, a começar pelo próprio narrador. A história é um relato de viagem ou um diálogo? Quem narra, afinal? É Hitlodeu ou

\footnotetext{
${ }^{115}$ Utopia, pg. 84; Vtopia, pg. 265.

${ }^{116}$ Utopia, pgs. 249-250.
} 
More? Inicialmente a história é um relato em primeira pessoa de uma viagem de More a Bruges como representante do rei. Num primeiro momento ele é um narrador onipresente. Os discursos são indiretos e bastante pontuados pelas considerações de More. Na medida em que os diálogos tomam forma, porém, o espaço de Hitlodeu se amplia e a personagem vai passando para o primeiro plano. Num dado momento, no diálogo na casa do Cardeal Morton, o "eu" deixa de ser More para ser Hitlodeu. A força de seu discurso neste momento empalidece o narrador principal, a ponto de fazê-lo desaparecer. More só emergirá novamente como interlocutor no diálogo que se segue, mas não mais como narrador, exceto no final da narrativa da viagem à Utopia. Mas no livro II, que consiste no relato de Utopia, é Hitlodeu quem narra.

Poder-se-ia tomá-lo como um narrador confiável? Ora, seu nome, Hitlodeu, significa "distribuidor de nonsenses", o que, num primeiro momento, parece desqualificá-lo - afinal, como dar crédito a um falador de nonsense? Por outro lado, Eric Nelson, em seu estudo sobre o uso dos termos gregos na obra, mostra que “"nonsense’ não é uma idéia inocente em Utopia” e lembra que quando Trasímaco diz: "Eu não aceitarei se você falar nonsenses como estes", dirigindo-se a Sócrates na República (336d) ${ }^{117}$, a palavra utilizada é hythlos. Para Nelson, o ponto de vista de Hitlodeu seria estranho ao de seus interlocutores, aos quais soaria como absurdo, ao contrariar "os costumes perversos da corte". De fato, Hitlodeu chega mesmo a afirmar que, numa corte, suas idéias poderiam ser tomadas como loucura por aqueles habituados a costumes perversos. Neste caso, Hitlodeu guarda um parentesco, não só com Sócrates, mas também com "Moria”, a loucura, personagem de uma obra contemporânea, Moriae

\footnotetext{
${ }^{117}$ Uma referência muito importante quanto a este aspecto é o livro de Nelson, The Greek Tradition in Republican Thought, Cambridge: Cambridge University Press, 2004.
} 
Encomium, dedicada ao próprio More, por seu amigo Erasmo, em referência ao seu nome de família.

Como vários autores já apontaram, exemplos deste tipo não faltam na obra. Eric

Nelson cita todo um conjunto deles:

A rede de trocadilhos gregos de More não é simplesmente entretenimento; ela organiza. Hitlodeu é um distribuidor de nonsense, e quase tudo o que ele descreve de suas viagens tem um nome cunhado de palavras gregas conotando 'nonsense' ou 'não-existente' (uma qualidade que torna as coisas nonsenses); os Polileritas são um povo de muito nonsense; os Acorianos são um povo sem país; Utopia é um 'não-lugar' - um trocadilho com 'lugar feliz' (eutopos) - e o título do seu governador é Ademos, um oficial 'sem povo'; o rio Anidro é sem água, e corre pela cidade Amauroto, a cidade 'desconhecida'. 118

Esta característica equívoca de Utopia, a obra, deu margem a diferentes interpretações. Durante um longo período, entre o século XIX e meados do Século XX, as diversas linhas interpretativas se dividiam grosso modo em duas vertentes: as que tomavam a obra como um passatempo literário, um jeu d'esprit, e aquelas que a tomavam como uma obra argumentativa séria com elementos satíricos. As que tomavam a obra neste segundo sentido eram basicamente as leituras católica e a marxista.

Chambers foi o inaugurador da interpretação católica. Para ele, como para outros intérpretes brilhantes que o seguiram, sendo o mais destacado deles o padre Edward

\footnotetext{
${ }^{118}$ Nelson, The Greek Tradition in Republican Thought, 2004, p. 20. Também na carta de More a Giles citada acima, em que ele fala sobre o uso da ficção na obra, estes mesmos exemplos são enumerados: "Não nego que se tivesse decidido escrever sobre uma república, e um conto deste tipo tivesse vindo à minha mente, eu talvez não tivesse evitado uma ficção por meio da qual a verdade, como um medicamento misturado com mel, pudesse entrar na mente de um modo um pouco mais agradável. Mas eu certamente teria suavizado um pouco a ficção, de modo que, enquanto me aproveitava da ignorância vulgar, daria indicações aos mais cultos que lhes permitiram ver do que eu tratava. Assim, se eu tivesse meramente dado tais nomes ao governador, ao rio, à cidade e à ilha que indicariam ao leitor informado que a ilha era lugar algum; a cidade, um fantasma; o rio, sem água; e o governador, sem povo; não teria sido difícil fazê-lo, e teria sido muito mais engenhoso do que aquilo que efetivamente fiz. Se a veracidade do historiador não tivesse de fato me exigido que o fizesse, eu não sou tão estúpido de modo a ter preferido aqueles nomes bárbaros e sem sentido, como Utopia, Anidro, Amauroto e Ademos". More, "Letter to Giles". In: Utopia, p. 251.
} 
Surtz, Utopia deve ser entendida como uma obra de um santo da Igreja Católica. Tratase basicamente de uma admoestação dirigida aos cristãos ingleses e do continente. Assim, seguindo a tradição tomista, que confere um papel à razão, More, num exercício imaginativo, construiria uma república modelar, ideal, com o uso da simples razão, a fim de mostrar aos cristãos, que, mesmo sem o concurso da Graça, pode-se conceber costumes mais justos do que os de seus contemporâneos. Utopia é uma república filosófica. É a melhor república, segundo a razão.

É nesta chave que, em seu artigo "Interpretations of 'Utopia”, padre Surtz analisa o significado de uma sextilha do poeta Anemolius (algo como cheio de vento), e uma quadra escrita em "língua" utopiana:

\section{Sextilha de Anemólio}

Utopia, em razão do isolamento, pelos antigos assim chamada, Agora êmula da Cidade de Platão,

Talvez a ela superior, pois aquilo que ele em letras

Delineou, eu, de uma só vez, o apresentei

Com homens, bens e leis maravilhosas.

Eutopia, a bom título, há que chamar-me. ${ }^{119}$

Vtopia priscis dicta, ob infrequentiam,

Nunc ciuitatis aemula Platonicae,

Fortasse uictrix, (nam quod illa literis

Deliniauit, hoc ego uma praestiti,

Viris \& opibus, optimisque legibus)

Eutopia mérito sum uocanda nomine ${ }^{120}$.

\section{Quadra em língua utopiense}

Utopo, meu soberano, de não ilha me fez ilha.

Única de todas as terras sem filosofia.

A cidade da filosofia descrevi-a eu aos mortais.

De bom grado partilho, o que é meu; sem pesar, recebo o que for melhor. ${ }^{121}$

Vtopus me dux ex non insula fecit insulam.

Vna ego terrarum omnium absque philosophia.

${ }^{119}$ Utopia, pg. 20; Vtopia, pg. 207.

${ }^{120}$ Utopia, pg. 20; Vtopia, pg. 207.

${ }^{121}$ Utopia, pg. 18; Vtopia, pg. 209. 
Ciuitatem philosophicam expressi mortalibus.

Libenter impartio mea, non grauatim accipio meliora ${ }^{122}$.

Segundo Surtz, como nada é ocioso nesta obra, a referência à República seria um indicativo de que se trata de uma república filosófica "construída seguindo de perto as linhas de Platão". Por isso mesmo ela é falha. Ao contrário do que poderia parecer, o ponto de vista de More não se confundiria com o de Hitlodeu. Enquanto ouvia o relato, More o avaliava tendo como critério a verdade revelada. Prova disso seria a fala do personagem More ao final da narração. Este, sim, o ponto de vista do autor:

Logo que Rafael acabou de fazer esta exposição, embora não fossem poucas as questões que me subiam ao espírito, pois nos costumes e nas legislações daquele me parecia haver instituições demasiado absurdas, não apenas quanto a planos de guerra e sua condução, quanto à concepção das coisas divinas e da religião ou sobretudo quanto às suas instituições, mas também, e ainda mais, quanto ao que constitui o fundamento supremo de toda e qualquer instituição, isto é, da vida e da subsistência de toda a comunidade: sem qualquer forma de comércio com dinheiro (disso se trata), cai por terra toda a fidalguia (nobilitas), a magnificência, o esplendor, a majestade, que, como sustenta a opinião pública, é a verdadeira beleza (decora) e ornamento (ornamenta) da República (Reipublicae)"(...). ${ }^{123}$

Assim, portanto, Utopia não seria perfeita, mas a melhor república possível construída pelo homem: "Vtopus me dux ex non insula fecit insulam", 24 , diz outro verso.

Não se trata, portanto, de uma obra de um comunista, mas de um humanista cristão.

O primeiro estudo marxista a respeito da Utopia de More foi escrito por Kautsky $^{125}$, que enxerga em More um homem contraditório, um cidadão burguês de

\footnotetext{
${ }^{122}$ Utopia, pg. 18; Vtopia, pg. 209.

123 "Haec ubi Raphael recensuit, quanquam haud pauca mihi succurrebant, quae in eius populi moribus, legibusque perquam absurde uidebantur instituta, non solum de belli gerendi ratione, \& rebus diuinis, ac religione, alijsque insuper eorum institutis, sed in eo quoque ipso maxime, quod maximum totius instituitionis fundamentum est uita scilicet, uictuque communi, sine ullo pecuniae commercio, qua uma re funditus euertitur omnis nobilitas, magnificentia, splendor, maiestas, uera ut publica est opinio decora atque onamenta Reipublicae (...)" Utopia, pg. 245; Vtopia, pgs. 414-415.

${ }^{124}$ Utopia, pg. 18; Vtopia, pg. 209.
} 
classe média ao mesmo tempo representante e crítico do capitalismo nascente; um homem cuja tragédia residiria em sua capacidade de divisar os problemas de sua época, sem que as condições materiais para a sua solução estivessem postas.

Estas linhas interpretativas com alguma variação dominaram os estudos sobre a obra até os anos 60 do século passado. Neste período, surgiu uma nova leitura que reabriu o debate ao colocar em evidência os aspectos satíricos da obra.

O primeiro estudo a tratar o livro como uma obra satírica foi o artigo já clássico de Heiserman, "Satire in the Utopia", publicado em 1963. Neste artigo, o autor sustenta que Utopia é uma obra inspirada nas sátiras de Luciano. Sátiras estas, aliás, traduzidas por More. Mas o que exatamente Heiserman entende por isso? Ele afirma que a sátira não é nem um simples jogo de espírito, nem uma obra argumentativa tradicional. A sátira seria uma via diversa. Segundo ele, um humanista poderia definir esta via diversa como "um gênero poético na medida em que emprega matéria ficcional, e que, diferente de outras formas poéticas, ensina a virtude pelo ataque aos vícios, por vezes, revelando as causas do vício"126. Assim, continua Heiserman, o humanista "não tomaria a sátira como uma homilia, um romance ou um discurso filosófico, embora ele pudesse tê-la considerado como um meio equivoco de ensinar a virtude". A fim de apoiar sua leitura, ele cita uma carta de Erasmo de Roterdam a Dorp: "se você não leu a Utopia de More, procure por ela sempre que você quiser se divertir ou, antes eu deveria dizer, se você quiser ver as fontes das quais surgem quase todas as doenças do corpo político."127 Neste trecho estariam claramente presentes os dois componentes da sátira: o sério e o cômico, ou, mais precisamente nos termos do autor, poesia e ensinamento.

\footnotetext{
${ }^{125}$ Trata-se do livro Thomas More e sua Utopia (1888), que, a despeito de seu anacronismo, traz, como nota Logan, boas análises das formas de organização sociedade utopiana. Para uma análise mais detida da obra de Kautsky, cf. Ames, Citizen Thomas More and his Utopia, 1949, pgs 1-21.

${ }^{126}$ Heiserman, "Satire in the Utopia", p. 163.

${ }^{127}$ Heiserman, "Satire in the Utopia", p. 164.
} 
Assim, a sátira se diferencia do jeu d'esprit, por abordar um assunto que importa a todos; e se diferencia do tratado, por sua forma. A sátira seria uma forma literária para tratar de maneira leve questões morais. "A boa sátira é didática sem pomposidade, poética sem frivolidade, provendo um meio ideal de advertir os mortais contra suas falhas"

De fato, é desta forma que o livro se apresenta para o leitor. Logo depois do seu título, que é um misto de brincadeira e seriedade (lugar nenhum e melhor república), nos deparamos com o seguinte complemento, que serve de apresentação:

Libellus uere aureus,

Nec minus salutaris qam festiuuis, Clarissimi disertissimique uiri THOMAE MORI Inclytae civitatis Londinensis ciuis \& Vicecomitis.

Chama atenção aqui o modo como o próprio More qualifica o seu libellus vere aureus: "Não menos salutar do que divertido". Desta forma, o autor dá indicações de que o deleite e a reflexão estão unidos em sua obra; mais do que isso, estão em equilíbrio, reivindicando o mesmo peso em ouro: "Nec minus... quam...”.

Mas é necessário dar ainda outra volta neste parafuso. A sátira é tradicionalmente ligada à crítica dos costumes e se dirige ao que há de vicioso, ao sórdido, ao tolo; já as utopias descrevem o ideal e o desejável. Como podem estar associadas? Elliott, no capítulo "Saturnália, sátira, e utopia" de seu livro The Shape of Utopia, discute esta questão. Segundo ele, é preciso discernir os meandros pelos quais é possível identificar uma ligação que não parece ser óbvia. Os dois modos estão associados por uma rede complexa de relações. Assim, há inicialmente

\footnotetext{
${ }^{128}$ Heiserman, "Satire in the Utopia", p. 167.
} 
(...) um emaranhado de linhas genéticas o qual, no caminho destas questões, leva a lugares inesperados. "Todas as utopias" diz Arthur Koestler, "são alimentadas das fontes da mitologia; os projetos de engenharia social são meramente edições revisadas de antigos textos." Na medida em que a utopia incorpora os desejos dos homens por uma boa vida, é parte de um complexo de idéias que inclui a Idade do Ouro, o paraíso terrestre, as ilhas afortunadas, a ilha dos abençoados e assim por diante. ${ }^{129}$

No entanto, Elliott dirá que as imagens de sociedades ideais, bem como sua rememoração por meio de festas, se ligaram, através do riso, às sátiras. As Saturnálias, que reviviam a Era de Ouro, continham em si a brincadeira e a farsa. Cronossolon é a paródia de Sólon, e denunciava a sua incongruência com este mundo, assim como marcava sua transitoriedade. As imagens do país da Cocanha, com patos assados que voavam anunciando sua suculência e rios de vinho, associam, como mostra Elliott, o desejo de felicidade e o riso.

Mas a utopia não se confunde com a Era de Ouro e as Saturnálias. Seu parentesco não as identifica plenamente, e o próprio Elliott as coloca em planos distintos:

\begin{abstract}
A Era de Ouro e a utopia, uma um mito, a outra um conceito, são ambas projeções das fantasias desejáveis dos homens, respondendo aos anseios pela vida feliz que os impulsionaram desde antes que a história começasse. (...) Identidade de origem, entretanto, não implica de modo algum identidade de função. Platão, empreendendo a busca socrática pelo sentido da justiça, é levado a conceber uma ordem social ideal uma utopia; mas a justiça, o objeto de sua busca, seria inútil, como aponta Hume enfaticamente, em uma sociedade como a da Era de Ouro. Os contornos e costumes destas terras ideais são de fato muito diferentes. Na Utopia o trabalho do mundo continua, racionalizado, limpo (...), dignificado; o trabalho está lá, entretanto, como uma condição necessária da existência de Utopia. Na Cocanha, diz a canção, "eles enforcariam o idiota que inventou o trabalho". ${ }^{130}$
\end{abstract}

A utopia, portanto, traz em si um elemento construtivo que aponta para o futuro.

A Era de Ouro é filha de uma sociedade estática. Utopos encheu de terror e admiração

\footnotetext{
${ }^{129}$ Elliott, The Shape of Utopia, p. 3-4.

${ }^{130}$ Elliott, Shape of Utopia, pg. 7.
} 
aqueles que não acreditavam na capacidade de realização do trabalho humano. "Não acredito que tais coisas sejam possíveis", diz Morus. "É porque você não conhece Utopia”, responde Hitlodeu ${ }^{131}$. O riso de Cocanha é um riso conformado, de quem pressente a distância entre o real e o que poderia ser, mas sem esperança de realização. O mesmo se dá com as Saturnálias, os sete dias de domínio de Cronos.

Da mesma forma, se do ponto de vista estético ela se vincula à tradição luciânica do serio ludere, ao mesmo tempo ela se configura como uma novidade. No que se refere aos expedientes formais, é possível divisar na utopia as características pelas quais as sátiras se definem, tais como a paródia (que inclui a mescla de gêneros como o diálogo e a narração ), a ambiguidade (que mescla o cômico com o sério para despistar o leitor), o expectador distanciado que olha o mundo a partir de um outro lugar, etc ${ }^{132}$. Entretanto, não basta elencar estes aspectos abstratamente. É preciso compreender como especificamente eles aparecem e se organizam na Utopia.

No seu artigo A Utopia e a sátira, Ana Cláudia Ribeiro traça as distinções entre a sátira luciânica e a utopia de Morus nos seguintes termos:

Morus, à diferença de Luciano, elabora uma ficção que se quer verossímil; ela é, porém, constituída de elementos inverossímeis, tanto em grandes linhas como no detalhe: pensemos nos já referidos nomes que apontam para a inexistência do que nomeiam, na radical uniformidade geográfica, urbana, arquitetônica e social, no absoluto comunismo de bens, na extrema racionalização e perfeição de todos os aspectos da vida individual e coletiva, na invariabilidade desta perfeição, onde não há lugar para imprevistos nem dissídios, na total regulação, controle e previsão das necessidades. ${ }^{133}$

Entretanto, o jogo entre o verossímil e o inverossímil talvez indique uma estrutura mais profunda, a qual responde e que tem a mesma raiz na distância entre a Era de Ouro e a

\footnotetext{
${ }^{131}$ Utopia, pg. 106; Vtopia, pg. 284-285.

${ }^{132}$ Cf. Ribeiro, “A Utopia e a Sátira”, pg. 141.

${ }^{133}$ Ribeiro, “A Utopia e a Sátira”, p. 143.
} 
Utopia. O fato de Luciano, logo no início das Histórias Verdadeiras, afirmar claramente que irá contar mentiras, enquanto More faz exatamente o oposto, é simétrico à plausibilidade da viagem de Hitlodeu em contraste com a implausibilidade da viagem de Luciano à Lua. Embora este último, ao se declarar um mentiroso, marque a sua distância com relação à obra de Homero (pois chama Ulisses de charlatão), ele ainda vive em um mundo em que depois das Colunas de Hércules o que se pode esperar é um mar de sargaços e atoleiros, enquanto que Hitlodeu dá a volta ao mundo com Américo Vespúcio.

A este respeito, é interessante lembrar ainda que, segundo Heiserman, tradicionalmente os satiristas se utilizavam de dois tipos de persona satírica: o falador de verdades, que pode ser um louco, um profeta ou um animal; e o viajante fantástico ou sonhador, que, após uma experiência em outros mundos, retorna como um estranho a sua terra natal. Mas o mesmo Heiserman aponta que na Utopia a persona do viajante estaria, pela primeira vez, amalgamada com a do falador de nonsense (ou melhor, aquele que diz a verdade sob a aparência do nonsense). Esta faceta de Hitlodeu aparece, como vimos, não somente na conversa em Antuérpia (na explicação que dá a Giles do por que não integraria o conselho do rei), mas principalmente na narração do jantar na casa do Cardeal Morton.

Este amálgama aparentemente se deve à combinação de duas estruturas: o diálogo e a jornada. No entanto, apesar do recurso novo que representa a fusão de duas figuras satíricas, para Heiserman, os objetos a serem criticados seriam mais convencionais, a saber: a corte e o que ele chama de os males dos tempos.

[P]odemos dizer que a nova ilha de Não-lugar existe apenas poeticamente, e que suas instituições são inventadas segundo o princípio satírico - não para incorporar "ideais" 
de uma república, nem tampouco um programa para reformas práticas, mas para condenar as loucuras correntes.

Hitlodeu começa com um dos objetos satíricos mais sobrecarregados de convenções - a corte. Cortesãos motivados pela ambição, príncipes egocêntricos que "se deleitam mais com questões de guerra (...) que com os bons destinos da paz", políticas determinadas pela "adulação", por "dizeres tolos e bajuladores"... Mas quando the pedem exemplos, Hitlodeu não descreve uma corte real, e sim a do bom Cardeal Morton. Já que a de Morton certamente não era uma corte corrompida por seu príncipe, Hitlodeu ridiculariza frequentadores tais como o advogado que defende o enforcamento de ladrões, e então prossegue - como seus ancestrais literários lhe permitem fazer - atacando os males do tempo: (...) a própria guerra, a "indolência" da nobreza, (...) mercenários bestiais, entre outros - todas acusações convencionais que implicavam, para os satiristas anteriores, que esta era uma época de loucura, pois as instituições da república violavam a ordem harmoniosa da natureza. ${ }^{134}$

Assim, como nos primeiros satiristas, Hitlodeu examinaria as fontes dos males dos tempos. Ocorre que, pela primeira vez, como aponta o próprio Heiserman, estas fontes remetem a uma raiz social. Ora, pela primeira vez os carneiros tornam-se devoradores de homens, efeito dos cercamentos, fenômeno moderno e inédito que expulsava os homens das terras e os conduzia para a forca.

Mas, apesar de ter dado com este precioso achado e até afirmar que os seus expedientes estruturais o conduzem para além do lugar comum, Heiserman termina por subsumir More inteiramente à tradição dos satiristas: "ao atacar estas loucuras, ao combiná-las em tais termos e mesmo ao inscrevê-las no movimento de cercamentos, More está seguindo a tradição satírica"135. Assim, os males mudam com os tempos, mas suas especificidades não se traduzem em grandes conseqüências.

Mas Hitlodeu não é apenas um amálgama de duas figuras satíricas tradicionais. Se ele é um viajante, ele não é um sonhador e não empreendeu uma viagem fantástica, mas, como vimos, percorreu o hemisfério sul em uma viagem bem mais prosaica. Ele também não é um falador de nonsense qualquer; como apontou Eric Nelson, seu nome

\footnotetext{
${ }^{134}$ Heiserman, "Satire in the Utopia", p. 167.

${ }^{135}$ Heiserman, "Satire in the Utopia", p. 168.
} 
remete a Sócrates. No Livro I da Utopia, como dissemos acima, Giles o aproxima de Platão e da figura do humanista.

Utopia, também, por mais estranha que seja, é caracterizada como uma república filosófica feita pelo homem. O gesto inaugural que a transformou em ilha é resultado de uma decisão meramente humana e fruto do trabalho de homens. Além disso, como foi apontado, nela o trabalho possui uma centralidade que está ausente de outros lugares ou eras fantásticas, tais como a Cocanha e a Idade de Ouro.

Será que não poderíamos, a partir destas considerações, compreendê-la de outra maneira? Será que o alvo de sua crítica, o mal moderno dos cercamentos, não tem um papel fortemente determinante no que se refere à estrutura da obra e aos seus personagens? Será que estas mudanças não acarretam uma mudança de sentido significativa em relação ao modelo anterior da sátira?

Um aspecto que chama a atenção em Utopia é que nós não acompanhamos a experiência transformadora do viajante Hitlodeu. O único trecho que mais se aproxima de uma experiência pessoal diz respeito aos povos contatados e lugares percorridos no período anterior à chegada à Utopia. Sabemos que, por insistência sua, Hitlodeu foi deixado por Américo Vespúcio num forte, juntamente com outros companheiros. Ali, acabaram por fazer amizade com um dos príncipes locais, o qual, por sua vez, forneceulhes meios (jangadas e carroças) para que pudessem percorrer o Novo Mundo, providenciando ainda um guia e provisões ${ }^{136}$.

Vale notar que o tom, neste trecho do início do livro, é distinto do restante da Utopia, contrastando tanto com o diálogo que o sucede, quanto com a forma mais árida pela qual é feita a descrição de Utopia no livro II. Aqui o relato ganha quase que o

${ }^{136}$ Utopia, pgs. 50-52; Vtopia, pgs. 233-234 
caráter de uma narrativa, apresentando uma cativante vivacidade que se mostra em pequenos detalhes, como quando conta que Hitlodeu e os companheiros "andavam despreocupadamente entre eles [os habitantes da terra]", avistando "por toda parte desolação e tristeza" numa terra "assustadora e agreste", ou, mais tarde, quando menciona o receio que tinham os marinheiros daquela terra em relação a se aventurar no mar, por desconhecerem o uso da agulha magnética - enquanto que a introdução desta por Hitlodeu os leva a enfrentar o mar no inverno "com mais ousadia que segurança".

Contava ele que, de facto, após muitos dias de caminho, haviam encontrado castelos e cidades além de agrupamentos muito bem organizados com população muito numerosa. É bem verdade que, sob a linha do equador, de uma parte e de outra, quase em todo o espaço que abrange a órbita solar, se estendem vastas zonas perpetuamente tórridas e desertas, por toda a parte desolação e tristeza à vista, assustadora e agreste, habitada por feras e serpentes ou, finalmente, por homens não menos ferozes que os animais selvagens nem menos perigosos. Depois, passada uma larga região, pouco a pouco tudo era mansidão, o sol fica menos agressivo, a terra macia com a verdura, as reações dos animais mais meigas, enfim, abrem-se os povoados, as cidades, as fortalezas e neles uma vida comercial intensa, por terra e por mar, não apenas internamente e com os vizinhos, mas também com povos afastados.

A partir daí, surgiu-lhe a possibilidade de visitarem muitas terras, ali e acolá, pois não havia navio algum que se fizesse a caminho em que ele e os seus companheiros não fossem aceites de bom grado. Os navios que se lhes depararam nas primeiras regiões eram, dizia, de casco chato, as velas eram estendidas em canas ou vimes entrelaçados, noutros lugares eram de couro, mas depois depararam com barcos de quilha recurvada e vela de cânhamo, enfim, em tudo semelhantes aos nossos. Os marinheiros nada desconhecem do mar e do céu. Mas, ao que contava Rafael, conseguiu ganhar-lhes as graças por os ter posto a par do uso da agulha magnética, de que antes nada sabiam e por isso era com receio que eles costumavam andar no mar alto, aonde, aliás, nem se aventuravam a não ser no verão. Agora, porém, com a confiança que têm na agulha magnética, enfrentam o inverno com mais ousadia que segurança, por tal forma que há risco de que uma coisa que se considerava vir a ser de grande proveito para eles, por imprudência, se possa tornar causa de grandes desgraças. ${ }^{137}$

É certo que estas histórias não são narradas em primeira pessoa. A figura de More como narrador ainda é bastante presente e se evidencia pelos verbos na terceira pessoa e por outros recursos literários. Ainda assim, Rafael se insinua no texto, não

\footnotetext{
${ }^{137}$ Utopia, pgs. 50-52 ; Vtopia, pgs. 234-237.
} 
somente naqueles aspectos que destacamos anteriormente, como também pelas constantes remissões à personagem. Mas, quando finalmente chegamos em Utopia, a personagem desaparece e sua experiência pessoal não é compartilhada conosco. A exposição apresenta um tom em boa medida impessoal ${ }^{138}$, outro traço formal digno de nota, afastando-se não apenas do relato de viagem a que nos referimos, mas mais ainda da vivacidade dos diálogos e das críticas pungentes do livro I (os quais, por outro lado, têm como pressuposto esta mesma experiência). Esta impessoalidade se expressa não só na forma, mas também no conteúdo, e deve ter sido um importante fator no enfado experimentado por Michelet ${ }^{139}$. Não há personagens na Utopia, nem peripécia, tampouco enlace e desenlace. De modo que ficamos sabemos como é a ilha, seu surgimento, sua forma, como é governada, de quantas cidades é composta e como elas são. Dos seus habitantes, sabemos como são suas casas e seus costumes (como se casam, como se vestem, como se reúnem em refeições coletivas e em festins e cultos públicos, como são tratados desde o nascimento até o momento em que são objeto de cerimônias fúnebres), mas não conhecemos nenhum utopiano pelo nome. Exceto pelo breve diálogo entre uma criança e sua mãe por ocasião da visita dos embaixadores

\footnotetext{
${ }^{138}$ Há algumas exceções esparsas, como quando são mencionados os livros que Hitlodeu traz consigo: "Por meu intermédio (pois, em vez de mercadorias, ao preparar a minha quarta viagem, coloquei no navio um lote de livros mediano, uma vez que decidiram não voltar lá tão depressa) têm eles agora a maior parte das obras de Platão, bastantes de Aristóteles, a obra de Teofrasto sobre as plantas (infelizmente mutilado em muitos pontos - de facto, durante a viagem por mar, um cercopiteco dera com o livro, que eu deixara descuidado, e, saltando, na brincadeira, rasgou algumas das páginas que arrancara aqui e ali). De entre as obras de gramática, ficaram apenas a de Láscaris, pois não levei comigo a de Teodoro; não levei qualquer outro dicionário que não fosse o de Hesíquio e Dioscórides. Demonstraram eles muito apreço pelos livros de Plutarco e ficaram seduzidos pelas historietas e pela graciosidade de Luciano. Dos poetas ficaram com Aristófanes, Homero e Eurípedes, além de Sófocles nos caracteres minúsculos de Aldo. Dos historiadores têm Tucídides e Heródoto, bem como Herodiano. Por sua parte, para a medicina um companheiro meu, Trício Apinato, levara consigo uns pequenos opúsculos de Hipócrates e a Microtechne de Galeno (...)". Cf. Utopia, pgs.181-183 Vtopia, pgs. 346-350 Mas não chega a alterar o tom geral que lembra um verbete de enciclopédia. Além disso, neste caso, é Hitlodeu quem dá a sua contribuição àquela sociedade e não o contrário.

${ }^{139}$ As frases iniciais dos capítulos do livro II dão o tom do relato: "A ilha da Utopia tem a largura de..."; "Quem conhecer uma das cidades conhece-as todas"; "Cada trinta famílias elege, todos os anos, um representante..."; "Existe uma só tarefa que é comum a todos, homens e mulheres: a agricultura". E o tom permanece o mesmo até o final do discurso que descreve a ilha de Utopia.
} 
Anemólios, e pela visita em si, que quebram a monotonia e a uniformidade da descrição, na Utopia, a pólis ideal, não acontece rigorosamente nada ${ }^{140}$.

Por que não acompanhamos o processo de transformação de Hitlodeu? Simplesmente porque isto não importa. Não se trata de Hitlodeu como modelo formativo, mas da república utopiana como matéria para discussão política. Assim, a crítica satírica, ao não se dirigir a males propriamente individuais e sim a males da república (no sentido de coisa pública) exige uma solução que inclui a passagem do âmbito da moral para o da política. Relembremos a já citada carta de Erasmo à Dorp: "se você não leu a Utopia de More, procure por ela sempre que você quiser se divertir ou, antes eu deveria dizer, se você quiser ver as fontes das quais surgem quase todas as doenças do corpo político." Mais adiante na mesma carta Erasmo faz referência ao que More tinha em vista nos seguintes termos:

Ele [More] publicou sua Utopia com o propósito de mostrar quais são as coisas que ocasionam danos às repúblicas, tendo a constituição inglesa [i.e., a estrutura social] especialmente em vista. ${ }^{141}$

Não se trata pois, dos males dos tempos em geral, mas da república e, em especial, da Inglaterra. Trata-se, portanto, de uma obra política. De modo que sabemos como Utopia foi forjada, como ela está organizada e mesmo algo do seu contato com o mundo exterior. Mas, o mais importante, como ela solucionou, através de uma mudança

\footnotetext{
${ }^{140}$ Assim, no único acontecimento propriamente dito que ocorre na viagem à Utopia, os embaixadores equivocados "se pavoneavam quando comparavam o luxo do seu trajar com a maneira simples como se vestiam os utopienses". Afinal, "traziam uma capa recamada de ouro, grandes colares e brincos dourados, a que se acrescentavam pulseiras de ouro nas mãos, além de joias aplicadas no chapéu, onde refulgiam margaridas e gemas, enfim, apresentavam-se engalonados com toda a parafernália que na Utopia ou se empregava no castigo dos escravos ou tinha marca infamante ou era dos brinquedos para as crianças. (...) poder-se-ia ver como as crianças, que já tinham abandonado as gemas e as margaridas, ao repararem que elas continuavam espetadas nos barretes dos embaixadores, chamavam a atenção das mães e batiam-lhes de lado, exclamando: - Olha, mãe, aquele pantomineiro, já tão grande, e a usar ainda aquelas bugigangas, como se fosse pequenino! A mãe, por seu lado, em ar sério, dizia-lhe: - Cala-te, filho; creio que é algum dos bobos dos embaixadores" Cf. Utopia, pgs 153-157; Vtopia, pgs. 323-325.

${ }^{141}$ Heiserman, "Satire in the Utopia", 1963, p. 164.
} 
estrutural, um problema eminentemente político. Por este motivo não há histórias em Utopia, nem tramas, nem personagens, mas estruturas e funções.

A Utopia não é a república perfeita, como nos mostra Surtz, mas é nas suas falhas que reside sua força: a Utopia é obra humana. Certamente ela não é um programa para reformas práticas, mas como parâmetro para a crítica, carrega uma ambigüidade constitutiva. Como seu narrador, Hitlodeu, não tem lugar na república tal como está; é nonsense porque não-existente; é nonsense como tudo o que sai da boca do filósofo, que fala a partir de outro lugar. Mas como Rafael (primeiro nome de Hitlodeu, que significa o curador dos deuses), traz em si uma promessa, uma possibilidade.

Lugar algum uma vez foi meu nome (...) lugar feliz deveriam me chamar. 


\section{Filosofia e Utopia: a cidade ideal como discurso filosófico}

A República de Platão é considerada a primeira formulação filosófica da cidade ideal, tendo mesmo sido apontada por alguns como fonte e modelo para a concepção de Thomas More. De fato, referências a Platão e à República estão em toda parte: o viajante que nos dá a conhecer a ilha é um navegador, porém "não como Palinuro, mas como Ulisses, melhor, como Platão"; na sextilha de Anemólio, seu poeta laureado, é a própria Utopia quem se apresenta como êmula da República; seu nome, segundo alguns intérpretes, teria sido extraído das páginas de Platão ${ }^{142}$. Até mesmo as dúvidas quanto à possibilidade de realização de um constructo tão somente imaginado já apareciam no interior da discussão da sua matriz grega ${ }^{143}$ e ressurgem na sua similar inglesa ${ }^{144}$.

No caso da obra platônica, entretanto, a realização da cidade ideal parece estar intimamente ligada à questão, em última instância, metafísica de realização da justiça no

\footnotetext{
${ }^{142}$ Rep. IX 592b: "Refere-se à cidade que edificávamos há pouco na nossa exposição, àquela que está fundada só em palavras, pois creio bem que não se encontra em parte alguma da terra." (grifo meu)

${ }^{143}$ Rep. V 471c: "Mas afigura-se-me, ó Sócrates, que, se te deixarem expor sobre este assunto, nunca mais te lembrarás da questão que puseste de parte para dizer tudo isto: como é que esta constituição é possível, e de que maneira o será."; e também Rep. IX 592b: "De resto, nada importa que a cidade exista em qualquer lugar, ou venha a existir, porquanto é pelas suas normas e pelas de mais nenhuma outra, que ele pautará o seu comportamento." Donald R. Morrison, comentador contemporâneo da República, ainda repõe esta questão nos seguintes termos: "Sócrates chama sua cidade ideal de 'Callipois'. Platão considerava que Callipois era realizável? Ele realmente acreditava que a cidade que retrata na República é a melhor sociedade humana? Como com tantas coisas mais em Platão, os acadêmicos discordam [a este respeito]." Cf. Morrison, The Utopian Character of Plato's Ideal City In: Ferrari,G. R. F. (ed). The Cambridge Companion to Plato's Republic, pg. 232.

${ }^{144}$ Cf. Utopia, pgs 244-246; Vtopia, pg. 414-415
} 
mundo do devir. Não é por acaso que a discussão se inicia com a pergunta colocada ao idoso Céfalo sobre aquele momento da vida denominado "limiar da velhice" e termina com o apólogo de Er, personagem que morre e ressuscita, compondo-se assim um círculo entre o princípio e o final da obra.

No início do livro, a resposta de Céfalo, que não é de modo algum insensata e chega a causar admiração ao próprio Sócrates ${ }^{145}$, condensa vários níveis de significação, que serão desdobrados ao longo do livro. Nela já se encontram associadas paixões e tirania $^{146}$, bem como infelicidade e disposição de caráter ${ }^{147}$. Esta última corretamente entendida como a verdadeira causa dos lamentos que se verificam entre aqueles que experimentam como perda da própria vida a perda de certos prazeres associados ao baixo ventre.

Embora, Céfalo seja fabricante de escudos, e não filósofo, seu ethos é aquele que é próprio do homem temperante, para quem a riqueza adquirida foi antes de tudo um meio para o exercício da justiça; e esta última, a justiça, é entendida por ele como "não ludibriar ninguém nem mentir, mesmo involuntariamente, nem ficar a dever, sejam sacrifícios aos deuses, seja dinheiro a um homem"148. Há que se ter em conta que, apesar de sua formulação ter sido problematizada por ser excessivamente genérica ${ }^{149}$, Céfalo não é em momento algum propriamente desmentido, e é na sua consideração sobre a justiça que se prenunciam os liames entre o metafísico e o transitório. Afinal, a

\footnotetext{
${ }^{145}$ Rep. I 329e

146 Rep. 329d: "Quando as paixões cessam de nos repuxar e nos largam, acontece exatamente o que Sófocles disse: somos libertos de uma hoste de déspotas furiosos."

${ }^{147}$ Rep. 329b-d: "A mim afigura-se-me, ó Sócrates, que eles não acusam a verdadeira culpada. Porque, se fosse ela [a velhice] a culpada, também eu havia de experimentar os mesmos sofrimentos devido à velhice, bem como todos quantos chegaram a esta fase da existência. (...) Mas, quer quanto a estes sentimentos, quer quanto aos relativos aos parentes, há uma só e única causa: não a velhice, ó Sócrates, mas o carácter das pessoas."

${ }^{148}$ Rep. I $331 \mathrm{~b}$

149 Segundo Goldschmidt, Céfalo apresenta apenas uma imagem da justiça e a primeira definição a ser examinada como hipótese é a de Simônides. Cf. Goldschmidt, Diálogos de Platão, pg. 122.
} 
verdade e a atribuição a cada um do que lhe é devido, lidos numa outra chave mais complexa, são indissociáveis na justa organização da República ideal, bem como na estrutura do universo.

No apólogo que encerra o livro, a estrutura do universo se apresenta de forma similar à estrutura da alma e à da cidade justa e ecoa os temores dos velhos quanto ao seu destino no Hades ${ }^{150}$ e as considerações de Sócrates a respeito do discurso de Trasímaco, para quem a tirania, a mais completa injustiça, "dá ao homem injusto o máximo de felicidade" ${ }^{151}$. Nesta fábula, aqueles que voltaram sua vida para o alto e em direção à razão e ao conhecimento têm sua recompensa na possibilidade de se elevar às formas; enquanto que aqueles que direcionaram sua vida às paixões, que constituem a parte inferior da alma, e se ativeram meramente às sombras, oferecidas pelo mundo do devir, recebem como quinhão a descida ao Tártaro ${ }^{152}$. Neste, o destino mais terrível está reservado justamente ao tirano, que, abandonado à escuridão e à violência, jamais poderá retornar ao mundo do devir ${ }^{153}$. Daí a gravidade da questão de Sócrates ${ }^{154}$ :

- Ó divino Trasímaco, depois de nos fazer um discurso como esse, pretendes ir embora antes que tenhas demonstrado a contento ou aprendido se é assim ou não? Ou crês que se trata de definir assunto de pouca monta e não o percurso de nossa vida, aquele que cada um de nós deve percorrer para viver uma vida muito profícua ${ }^{155}$

O tirano como o mais injusto dos homens não é somente aquele que dá vazão às próprias paixões, mais que isso, é o próprio negativo do bom governante; suas ações, à mercê dos desejos cegos e inconstantes do baixo ventre, são antipolíticas e, deste modo,

\footnotetext{
${ }^{150}$ Rep. I 330d-e, 331a.

${ }^{151}$ Rep. I 344a.

${ }^{152}$ Rep. X 614c-d, 621c-d.

${ }^{153}$ Rep. X 615c-e, 616a.

${ }^{154}$ Goldschmidt parece ir na mesma direção ao afirmar que “(...) Trasímaco, sem prestar atenção ao movimento normal do conhecimento humano, vem confundir a ordem estrutural e, surdo à mensagem da Essência, professa uma doutrina ímpia, pecando assim contra a ordem divina." Cf. Goldschmidt, A Redução dos antivalores, in: ${ }^{155}$ Rep. I 344d-e. Diálogos de Platão, pg. 127.
} 
têm como consequência o negativo da república. A injustiça que comete é a mais completa, afirma Trasímaco, pois "arrebata os bens alheios a ocultas e pela violência, quer sejam sagrados ou profanos, particulares ou públicos, e isso não aos poucos, mas de uma só vez."156

Entretanto, Trasímaco não é somente aquele que elogia a injustiça, um antivalor $^{157}$, e tem a tirania como a forma de vida propriamente bem-aventurada; é também quem introduz um ponto de virada na discussão, traduzindo-a, pela primeira vez, em termos políticos. Portanto, a sua fala é aquela que, ao afirmar a negatividade, enseja a discussão que nos conduzirá até a cidade ideal. A argumentação de Trasímaco se sustenta em dois pontos: a justiça é a vantagem do mais forte, entendido como o governante; e a vida do injusto é mais feliz do que a vida do justo.

A refutação do primeiro ponto por Sócrates se estrutura pelo estabelecimento de uma relação entre carência e arte e se alicerça na ideia de que o conhecimento se dá em benefício de uma determinada carência, mas de modo que não seja por acidente. Assim, a medicina é a arte de curar, mas não a navegação, embora eventualmente possa devolver a saúde ao marinheiro. De forma que, a cura, por exemplo, vantagem peculiar à medicina, independente do lucro que porventura o seu artífice possa auferir, sempre será destinada àquele a quem se aplica, ao carente, portanto, ao mais fraco. ${ }^{158}$

Mas a justiça é uma arte, uma espécie de conhecimento? No que respeita ao segundo ponto, se a vida do injusto é mais feliz do que a do justo, a refutação se concentra primeiramente na boa medida da verdade, do belo e do bem e na ausência de medida da ignorância e do mal. O músico pretende afinar o seu instrumento melhor do que o ignorante na arte, mas não mais do que o seu igual. O mesmo se dá com o justo,

${ }^{156}$ Rep. I 344a.

${ }^{157}$ Cf. Goldschmidt, A Redução dos antivalores, in:

${ }^{158}$ Rep. I 346d. Diálogos de Platão, pgs 121 a 127. 
mas não com o injusto, cuja característica é a ausência de medida, o que lhe impele a "querer ser superior a quem é igual e a quem não é igual a ele"159. Ora, aquele que não tem medida ignora. Em segundo lugar, a demonstração de Sócrates se voltará para a necessidade da justiça, pois mesmo os injustos não podem passar sem ela, uma vez que a ausência desta virtude inviabilizaria qualquer associação, ainda que de ladrões. A razão disso é que a injustiça fomenta o ódio, a rebelião, a divisão, enquanto que para agir conjuntamente é preciso alguma concórdia. Em se tratando de uma virtude constitutiva, não pode haver cidade sem que em alguma medida não esteja presente a justiça. Resta saber em que medida a própria associação humana é necessária.

Antes, porém, de prosseguirmos no raciocínio, retomemos o percurso da refutação a fim de atar os últimos fios desta trama delicada. Ao seguir a discussão a partir de cada consenso obtido, temos a seguinte sequência: toda arte é para a vantagem daquele a quem se destina; as artes, o conhecimento e a sabedoria caracterizam-se pela medida, e a ignorância, pela falta ou excesso; a justiça possui uma medida, a injustiça, não; o artífice, o sábio e o justo são aqueles que possuem o senso desta medida, sendo, portanto, sensatos; neste sentido, o ignorante e o injusto são carentes desta medida, insensatos. Além disso, a injustiça produz ódio e divisão, o que impede a concórdia necessária para qualquer associação ou ação. Para que a concórdia ocorra é necessário que haja justiça. Portanto, a injustiça completa leva à inação e impotência completa.

Deste modo, a injustiça se mostra viciosa em termos de discernimento e capacidade de ação. Como a justiça é uma virtude própria da alma, cuja tarefa é deliberar, governar e também bem viver, uma alma viciosa deliberará mal, agirá mal e viverá mal. Assim, o injusto é infeliz.

${ }^{159}$ Rep. I 350b. 
Qual o papel da afirmação do antivalor e da negação da justiça? Em outras palavras, qual o papel da intervenção de Trasímaco? Ora, foi a total negação da justiça enquanto valor que tornou necessário a Sócrates argumentar em oposição, de maneira a demonstrar a afinidade da justiça com outras artes, caracterizá-la como uma virtude da alma e ainda como pressuposto de qualquer associação humana e, assim, da vida feliz. Mas, mais importante para o que nos interessa aqui, a intervenção de Trasímaco também efetuou pela primeira vez no diálogo a passagem da justiça entendida tão somente como uma questão individual e moral para a justiça entendida como uma questão também política. Ora, como se sabe, o exame completo da questão exigirá que este aspecto seja desdobrado ao longo de todo o restantes da obra.

Assim, a certa altura do livro $\mathrm{II}^{160}$, Sócrates afirma que recorre ao exame do processo de formação de uma cidade a fím de, "numa escala mais ampla" "161, melhor divisar a questão, uma vez que a "justiça é de um só indivíduo" 162 e "também de toda a cidade"163. Para tanto, convém imaginar uma cidade desde a sua fundação, pois, assim procedendo, pode-se observar como surgem a justiça e a injustiça em seu interior ${ }^{164}$. Porém, a fundação desta cidade imaginada começa pelo homem, ou melhor, por suas carências ${ }^{165}$. E o que se nota mais imediatamente é que, para viver, um homem precisa de alimento, moradia, vestimenta e calçados. De certo modo, o homem experimenta uma carência que lhe é constitutiva, mas que o leva para além de si. Assim, embora Platão não o diga, o que está pressuposto aí é um homem que ao mesmo tempo é menos

\footnotetext{
${ }^{160}$ Rep. II 368d-e, 369a.

${ }^{161}$ Rep. II 369a.

${ }^{162}$ Rep. II 368e.

${ }^{163}$ Rep. II 368e.

${ }^{164}$ Rep. II 369 a: “- Ora, pois - disse eu - se considerássemos em imaginação a formação de uma cidade, veríamos também a justiça e a injustiça a surgir nela? - Em breve o veríamos - retorquiu ele."

${ }^{165}$ Rep. II 369b: “ - Ora, disse eu - uma cidade tem sua origem, segundo creio, no facto de cada um de nós não ser auto-suficiente, mas sim necessitado de muita coisa."
} 
(enquanto falta, carência, necessidade) e mais do que ele mesmo (aquilo que não é ele: alimentos, roupas, calçados, abrigo). Isto acontece porque o homem está num mundo que também é um incessante movimento de passagem do ser para o não-ser - o mundo das necessidades ${ }^{166}$.

O homem solitário, não sendo autossuficiente para suprir suas incontornáveis carências, precisa se associar a outros homens, cada qual com inclinações naturais para desempenhar certas tarefas. Sendo assim, também a associação é própria do homem, tão necessária e constitutiva quanto suas carências. Como as associações humanas só podem existir se houver justiça, pode-se afirmar que a justiça é própria do homem também neste sentido. Pode-se mesmo dizer que a natureza multiplica as carências e diferencia os homens, enquanto que a justiça os une. Portanto, se a justiça é uma virtude própria da alma (a fim de que ela possa bem deliberar e governar, conforme referimos acima, tornando os homens melhores e mais sábios), ela também é própria da vida, na medida mesma em que ela é necessária para a subsistência concreta dos homens, os quais, por natureza, sozinhos não se bastam a si mesmos.

Simultaneamente individual e coletiva, sendo uma virtude da alma e da cidade, a justiça é a um só tempo também ética e política. Por isso, a pergunta pela definição de justiça e o seu exame nos conduzem por uma via de mão dupla, transitando-se necessariamente da constituição do homem para a da cidade e vice-versa. Mas como Platão perfaz este caminho e qual a sua forma?

Novamente é uma "necessidade", uma demanda da parte apetitiva da alma humana, que enseja a temática da formação. Após a descrição das necessidades

\footnotetext{
166 "Só se pode fundar a Cidade sobre o princípio que domina o mundo do devir, a necessidade. (...) Assim como Aristóteles, Platão não denega à Cidade como causa final 'o Belo', isto é, a Virtude. Ele o sugere, desde o final do Livro II e, em todo o diálogo, não cessa de afirmá-lo. No entanto, estamos agora, no nível da Imagem, em que não se devem esperar ensinamentos que só poderão ser dados a partir da Definição." Goldschmidt, V. Diálogos de Platão, pg. 258-259.
} 
essenciais, Sócrates, instado pelos protestos de Gláucon ${ }^{167}$, concede que a cidade tenha prazeres não necessários ${ }^{168}$. A cidade agora "plena de humores"169 conduz logicamente à necessidade de avançar sobre o território vizinho ou a se proteger de outras cidades semelhantes, o que leva à necessidade de guardiões.

A formação dos guardiões ocupa um amplo espaço no livro. Platão procura determinar até mesmo como os poemas devem ser contados, como os deuses ${ }^{170}$ e heróis devem ser retratados. A música e a ginástica devem ser devidamente balanceadas para que não se formem brutos ou cidadãos excessivamente delicados. O espaço que é dado à formação parece sugerir certa plasticidade humana, mas esta plasticidade não parece ser plena, afinal somente alguns se tornarão guardiões e destes, poucos serão chamados verdadeiros guardiões ou filósofos. A cidade ideal depende de homens justos e eles são produzidos por uma educação que visa torná-los temperantes, corajosos e sábios.

Paradoxalmente, a educação dos cidadãos (pois todos participam em algum grau desta educação que irá formar os futuros guardiões) passa justamente por moderar e moldar os apetites, estes impulsos cegos que tornam os guardiões necessários. Assim, haverá música, mas ela deverá ser adequada quanto às palavras, a harmonia e o ritmo. Quanto à harmonia, por exemplo, deverá haver dois modos básicos: aquele que imita a

\footnotetext{
${ }^{167}$ Rep. II 372d-e: “- Se estivesses a organizar, ó Sócrates - interveio ele - uma cidade de porcos, não precisavas de outra forragem para eles. - Mas então como há-de ser, ó Gláucon? - O costume respondeu ele - . Acho que devem reclinar-se em leitos, se não quiserem que se sintam infelizes, e que jantem, à mesa, iguarias como hoje há, e sobremesas."

${ }^{168}$ Rep. II 372e, 373a: “- Seja - disse eu - . Compreendo. Não estamos apenas a examinar, ao que parece, a origem de uma cidade, mas uma cidade de luxo. Talvez não seja mau. Efetivamente, ao estudarmos uma cidade dessas, depressa podemos descobrir de onde surgem nas cidades a justiça e a injustiça. A verdadeira cidade parece-me ser aquela que descrevemos como uma coisa sã, mas, se quiserdes, observaremos também a que está inchada de humores."

169 Pode causar estranhamento o fato de a cidade estar "inchada de humores", mas isto pode ser explicado a partir da interpretação de Goldschmidt, com a qual estamos de acordo neste aspecto: "Para considera a Justiça na cidade, é preciso começar por estudar como ela se forma uma cidade ou $a$ cidade (...), mas não uma cidade boa. Parte-se sem nenhuma exigência." Goldschmidt, V. Diálogos de Platão, pg. 258.

${ }^{170}$ Rep. II 379b.
} 
voz e as inflexões do homem corajoso na guerra, e aquele que corresponde aos padrões do homem que

se encontra em actos pacíficos, não violentos, mas voluntários, que usa do rogo e da persuasão, ou por meio da prece aos deuses, ou pelos seus ensinamentos e admoestações aos homens, ou, pelo contrário, se submete aos outros quando lhe pedem, ou ensinam ou o persuadem, e, tendo assim procedido a seu gosto sem sobranceria, se comporta com bom senso e moderação em todas estas circunstâncias, satisfeito com o que the sucede. ${ }^{171}$

Aqueles que produzem simulacros ou poemas com personagens enganadores ou fora de si também não devem ser admitidos seja porque afastam os homens da verdade, seja porque fazem com que tomem por modelo a ausência de discernimento.

Compreendemos melhor o significado desta educação para a República quando tomamos em exame os termos pelos quais Platão define a coragem:

A coragem é uma espécie de salvação (...) da opinião que se formou em nós, por efeito da lei, graças à educação, sobre as coisas a temer que existem, e a sua qualidade. Por "salvação através de todas as vicissitudes", entendia eu o facto de uma pessoa a conservar no meio dos desgostos, dos prazeres, dos desejos e dos temores, sem a abandonar. ${ }^{172}$

Trata-se, portanto, de preservar a opinião reta e perseverar nela mesmo diante das adversidades e dos prazeres. O guardião não é somente aquele que protege a cidade no sentido material de um eventual ataque externo, mas aquele que guarda na alma os seus valores como uma "tintura indelével" $" 173$ e luta permanentemente por eles contra os vícios $^{174}$. Assim como a defesa do antivalor (a injustiça) por parte de Trasímaco

${ }_{171}^{172}$ Rep. III 329a-c.

${ }_{172}$ Rep. IV 429c-d.

${ }_{174}^{173}$ Rep. IV 430a-b.

174 "If the city is going to have warriors, it has to have warriors of the right sort, and Socrates proposes that they will be produced by a kind of upbringing and education that in effect combines an ordinary wealthy Athenian boy's experience with a considerable number of Socratic (or Platonic) elements - 
permitiu um reequacionamento dos termos da discussão da justiça, a cidade luxuosa e

cheia de humores revindicada por Gláucon permite uma compreensão mais acurada da

coragem para o enfrentamento das paixões e dos vícios que ameaçam a cidade e a alma.

Mais do que isto, a argumentação, ao mostrar como deve ser a educação do guardião,

demonstra ao mesmo tempo, como se forma um molde vicioso que pode fomentar uma

opinião não reta e paixões ruinosas ${ }^{175}$. Vale a pena notarmos ainda que certos pontos

desta argumentação são recorrentes na obra de Platão, indicando sua importância ${ }^{176}$.

including, as it happens, the elimination, in the physical regime of the guards, of precisely those luxuries that Glaucon insisted on including in the city (404b ff.): a point that is thoroughly underlined at the beginning of Book 4, when Adeimantus interrupts to object that Socrates has robbed the guards of everything that people think makes them happy. Socrates responds, as we'd expect, that he wouldn't be surprised if they were in fact happiest just like that." Rowe, Christopher. The Place of Republic in Plato's Political Thought. In: Cambridge Companion to Plato's Republic, pgs 44-45.

${ }^{175}$ Cf. Rep. II 377b: "Ora tu sabes que, em qualquer empreendimento, o mais trabalhoso é o começo, sobretudo nessa altura que se é moldado, e se enterra a matriz que alguém queira imprimir numa pessoa?”; cf. também Rep. II 377c: “- Logo, devemos começar por vigiar os autores de fábulas, e selecionar as que forem boas, e proscrever as más. As que forem escolhidas, persuadiremos as amas e as mães a contá-las às crianças, e a moldar as suas almas por meio das fábulas, com muito mais cuidado do que os corpo com as mãos." Cf. ainda Rep. II 378a-e em que Platão discorre longamente sobre como as fábulas de Homero e Hesíodo podem, antes mesmo do desenvolvimento da razão, levar um jovem a supor, por exemplo, que "ao cometer os maiores ultrajes, não faz nada de surpreendente, nem tão-pouco ao castigar por todos os modos um pai que lhe fez mal, mas estaria a fazer o mesmo que os primeiros e os maiores dentre os deuses".

${ }^{176}$ Afinal, Êutifron, ao levar o pai aos tribunais, não supunha agir piedosamente, imitando Cronos e Zeus? "Pois bem, digo que piedoso é o que eu mesmo estou fazendo agora: a quem age mal - quer em relação a homicídios, quer em relação a furtos de objetos sagrados - ou comete outra falta qualquer desse tipo, processar, mesmo que por acaso seja o pai, seja a mãe ou outra pessoa qualquer; e que não processar é ímpio. (...) Pois ocorre de os próprios homens crerem em Zeus como o melhor e mais justo dos deuses, e de reconhecerem que prendeu o próprio pai porque engolia os filhos de modo não justo, e que este mesmo, por sua vez, também mutilou o próprio pai por outros motivos afins; mas comigo se exasperam porque processo meu pai por agir mal - e assim eles vão entrando em contradição consigo mesmos, ao falarem dos deuses e ao falarem de mim..." (Platão. Sobre a Piedade (Eutifron), 5-6). E o próprio Sócrates não foi também acusado de impiedade, tal como o pai de Êtifron, em virtude de uma opinião que se formou entre seus concidadãos, no caso de alguns, ainda na juventude? "Esses, varões atenienses, os que espalham essa fama - esses são os meus mais hábeis acusadores, pois os que lhes deram ouvidos consideram que os que investigam essas coisas também não creem em deuses. Depois, esses acusadores são muitos e têm me acusado já faz muito tempo, falando junto a vocês, além do mais, naquela idade em que mais seriam convencidos (alguns de vocês eram meninos ou adolescentes), simplesmente acusando de forma isolada - sem que houvesse defesa. E o mais inominável de tudo é que não é possível saber e dizer nem seus nome, a não ser de um que por acaso é comediógrafo. (...) Vocês mesmos já viram isso na comédia de Aristófanes, um Sócrates lá (aponta para o alto), balançando, afirmando "aeroandar" e asneando muitas outras asneiras sobre as quais não entendo coisa alguma, nem muito nem pouco..." (Platão, Apologia de Sócrates, 18-19). A partir destes exemplos, podemos depreender que este processo formativo da parte da alma que deverá desenvolver a coragem, o qual ficará a cargo das musas, não é de algo de pouca monta. 
No conjunto deste movimento é possível perceber que, como mostrou Victor Goldschmidt, ocorre um processo de depuração que conduz da imagem apreendida a partir da experiência até a definição, a essência e a ciência. Este processo de conhecimento é também ascensional rumo à abstração. Como as imagens produzidas pelo devir são opiniões, não sendo, portanto, investidas de caráter absoluto, a certeza só será obtida no final do percurso, quando se alcança a ciência. Desta forma, tanto a cidade inicialmente imaginada por Sócrates (a chamada "cidade de porcos"177) quanto a cidade luxuosa proposta por Gláucon, ambas são imagens de cidades quaisquer produzidas em função do objeto investigado, a saber: a definição de justiça. Para alcançar a definição, a estratégia de Sócrates consiste em examinar a gênese da cidade segundo os imperativos do mundo do devir. Nele o que aparece de mais evidente são as necessidades que se impõem aos seres humanos. Entretanto, a objeção de Gláucon atende a um imperativo humano não tão imediato, mas que está presente. Ora, os homens não são animais e cedo ou tarde aparecerão as demandas por uma vida mais prazerosa. Se bem atentarmos, as demandas de Gláucon são bastante modestas (carne e peixe, sobremesa, mesa, cama para dormir), mas Sócrates irá ampliá-las:

\begin{abstract}
Bem, estas determinações não bastam, ao que parece, a certas pessoas, nem esse passadio, mas acrescentar-lhe-ão leitos, mesas e outros objectos, e ainda iguarias, perfumes e incenso, cortesãs e guloseimas, e cada uma destas coisas em toda a sua variedade. Em especial, não mais se colocará entre as coisas necessárias o que dissemos primeiro, - habitações, vestuário e calçado - ; ir-se-á buscar a pintura e o colorido, e entender-se-á que se deve possuir ouro, marfim e preciosidades dessa espécie. É ou não? ${ }^{178}$
\end{abstract}

\footnotetext{
${ }^{177}$ Gláucon chama a cidade inicialmente imaginada por Sócrates de cidade de porcos (Rep. II 372d-e). Posteriormente, alguns comentadores assumem esta nomeação para se referir a ela e distingui-la da cidade de luxo. Morrison e Rowe sustentam inclusive que esta é que seria a verdadeira cidade socrática, que prescindiria de guardiães e de todas as instituições imaginadas para contornar a "febre" introduzida por Gláucon.

${ }^{178}$ Rep. II 373a.
} 
Esta ampliação consiste num processo análogo ao do geômetra quando prolonga a linha imaginária para melhor calcular a figura. Podemos supor que estamos diante do mesmo expediente utilizado por Sócrates para analisar a justiça na cidade antes do indivíduo $^{179}$. Platão parece colocar a demanda por prazer na boca de um jovem em atenção ao decoro; é significativo, porém, que esta demanda não provenha de um defensor do antivalor, mas do jovem futuro filósofo ${ }^{180}$. Se esta hipótese estiver correta, também podemos atribuir ao decoro a contrariedade do filósofo no momento em que cede a estes mesmos apelos. O fato é que, se a cidade luxuosa conduzirá mais facilmente à guerra ${ }^{181}$ e aos vícios, tampouco a cidade saudável para Sócrates ("de porcos" para Gláucon) estará a salvo das adversidades, uma vez que a justiça e a injustiça são inevitáveis no mundo do devir ${ }^{182}$.

Em todo caso, o que podemos verificar é que os princípios da justiça, na cidade ideal, e da injustiça, na sua decadência, já estão presentes nos primeiros delineamentos

${ }^{179}$ Cf. Rep. II 368d-e: “Ora, uma vez que nós não somos especialistas, entendo - prossegui - que devemos conduzir a investigação da mesma forma que o faríamos, se alguém mandasse ler de longe letras pequenas a pessoas de vista fraca, e então alguma delas desse conta de que existiam as mesmas letras em qualquer outra parte, em tamanho maior e numa escala mais ampla".

${ }^{180}$ A tese de que Gláucon apresenta características próprias de um guardião, que permitem tomá-lo como um jovem filósofo, é desenvolvida, entre outros autores, por Roberto Bolzani Filho no artigo "Glauco, guardião do logos". Bolzani argumenta que trechos como o início do livro II (onde Gláucon insiste em que Sócrates retome a discussão sobre a justiça, colocando dúvidas em relação à refutação efetiva dos argumentos de Trasímaco e apontando que não se conseguira determinar em que consistiria a justiça em si mesma) "mostram que em Glauco se apresentam, ao menos em esboço, traços da natureza filosófica que o diálogo construirá e proporá como conditio sine qua non para a existência de uma cidade justa. Já sua capacidade de recuperar uma posição significativa a respeito do assunto em questão, embora contaminada pelo páthos de um sofista como Trasímaco, traduzindo-a agora para a boa linguagem filosófica - por assim dizer, compreendendo-a mais adequadamente do que seu próprio defensor -, somada a outras características, evidentes em suas intervenções ao longo da conversação, podem ser interpretadas como a presença já necessária, em certa medida, daquela potência filosófica que o diálogo mostrará ser, mediante a correta educação, a única forma de obter uma cidade justa e feliz. Ou, se essa afirmação for demasiado forte, poderemos ao menos dizer que, como interlocutor de Sócrates, ele exibe certas qualidades, perceptíveis em sua retomada da tese de Trasímaco e em vários outros momentos, que o tornam uma espécie de interlocutor necessário, o que pode significar que, agora, é preciso que Sócrates tenha um novo tipo de interlocutor, diferente dos que com ele travaram conversação em diversos diálogos considerados "socráticos" de Platão." Bolzani Filho, R. "Glauco, guardião do logos”. In: Doispontos, Curitiba, São Carlos, vol. 10, n. 2, pgs. 12-13.

${ }^{181}$ Rep. II $373 \mathrm{~d}-\mathrm{e}$.

${ }^{182}$ Cf. Rep. II 372e: "Não estamos apenas a examinar, ao que parece, a origem de uma cidade, mas uma cidade de luxo. Talvez não seja mau. Efectivamente, ao estudarmos uma cidade dessas, depressa podemos descobrir de onde surgem nas cidades a justiça e a injustiça.” (grifo meu). 
da cidade. Enquanto na "cidade de porcos" já se verifica o princípio da divisão do trabalho, que será a base sobre a qual mais tarde se erigirá a justiça, na cidade de luxo já aparece o núcleo da injustiça que é o desejo por prazer e riqueza que leva à guerra e à tirania.

Procuraremos inverter os termos de Platão e pôr em evidência os princípios que levam à desagregação da cidade, buscando assim obter uma compreensão mais exata a respeito daquilo que a cidade ideal procurava evitar. Além disso, é de especial importância para nós, aqui, entender o processo que leva ao surgimento de uma personagem do discurso platônico que resurgirá com grande relevância na Utopia: os zangões.

Deixando de lado a fala das musas no início do livro VIII, Platão atribui a origem da desorganização da cidade à degeneração dos guardiões, a qual dá ensejo a discórdias e rebeliões que subvertem a configuração inicial. Ocorre que a cidade começa a se dividir em dois grupos, um formado pelos guardiões verdadeiros e auxiliares, outro formado pelas raças de bronze e ferro. O primeiro grupo procura manter a organização anterior, que correspondia à justiça, enquanto que o segundo grupo luta pela posse crescente de bens e riquezas. Após embates, chega-se a um acordo em que a propriedade de terras e riquezas é permitida a todos. Tem assim inicio a Timocracia, tipo de governo entre a aristocracia e a oligarquia e que mescla traços dos 
dois. $\mathrm{Na}$ aparência, ainda se assemelha à aristocracia da cidade ideal ${ }^{183}$, mas, por conta da propriedade privada, os governantes agora

serão cobiçosos de riquezas como os que vivem no regime oligárquico, adoradores apaixonados do ouro e da prata, à ocultas, pois são possuidores de celeiros e de terrenos particulares, onde os colocam para os manterem escondidos, e bem assim de casas que os abriguem de todos os lados, verdadeiros ninhos privados, dentro dos quais desbaratarão grandes somas com mulheres e com quem mais lhes apetecer. ${ }^{184}$

Neste governo, a música e a razão se enfraquecem ${ }^{185}$, perdem o seu papel formativo para a ginástica e o gosto pelo conhecimento cede lugar ao das disputas e das honrarias. O timocrata é dotado de um caráter ambíguo, inicialmente dividido entre a razão e as paixões ${ }^{186}$, mas como não possui as habilidades do verdadeiro guardião ${ }^{187}$, visto que não recebeu a formação adequada, "entrega o domínio de sua pessoa para a parte intermediária, que é ambiciosa e exaltada, tornando-se um homem orgulhoso e amigo das honrarias" ${ }^{\prime 188}$. Este caráter dúplice, dividido entre uma aparente austeridade (simulacro público dos guardiães da aristocracia, sem no entanto compreendê-los) e os prazeres furtivos, procurando compatibilizar os dois lados, acaba por tornar-se avaro com seus bens e dissipador dos alheios ${ }^{189}$.

$\mathrm{Na}$ oligarquia, entretanto, a aparência de aristocracia é definitivamente abandonada e o apreço pela virtude dá lugar à valorização ostensiva das riquezas. A virtude agora não é mais honrada, mas sim as riquezas e os ricos. Uma vez no poder, os oligarcas procuram impedir os demais de alcançá-lo, estabelecendo um novo critério, o

\footnotetext{
${ }^{183}$ Rep. VIII $547 \mathrm{~d}$.

${ }^{184}$ Rep. VIII 548a-b.

${ }^{185}$ Rep. VIII 549b.

${ }^{186}$ Rep. VIII 550a-b.

${ }^{187}$ Rep. VIII 549a.

${ }^{188}$ Rep. VIII 550b.

${ }^{189}$ Rep. VIII 548 b-c.
} 
censitário. Este regime, embora produza diversos males, tais como impedir, por conta da origem social, que pessoas adequadas sejam alçadas ao poder, violar a boa ordenação e a divisão do trabalho e dividir a cidade em duas que se opõem, derribando a unidade, a justiça e a razão, tem seu aspecto mais terrível naquilo que Platão chama de maior dos males: o fato de possibilitar o surgimento de uma nova espécie de homens - que após alienarem e dissiparem todos os seus bens, passam a habitar na cidade sem participar de qualquer de suas atividades - os chamados zangões. Estes esbanjadores, após dilapidarem suas posses, caem na indigência e, tal como seus equivalentes alados são a desgraça da colmeia, estes zangões são a desgraça para a sua casa e para a cidade, tornando-se mendigos ou malfeitores ${ }^{190}$.

O caráter correspondente ao regime oligárquico, por sua vez, é bastante complexo. Seu pai é um timocrata empobrecido e humilhado após ter sido delatado por outros. Ele, igualmente humilhado, desfaz-se do amor pelas honrarias e pela competição e põe-se a trabalhar e a amealhar fortuna e, na medida em que consagra sua vida a acumular, não valoriza senão as riquezas. Torna-se assim mais avaro ${ }^{191}$ que seu pai, pois fez do desejo de riquezas seu mestre e senhor, e a ele submete a razão (agora convertida em cálculo para aquisição de bens) e a honra ${ }^{192}$, pois não conhece as musas e nem tem qualquer inclinação ou interesse por elas. E é esta mesma falta de instrução que faz com que nutra desejos semelhantes aos dos zangões, "uns que o levam a mendigar, outros a praticar o mal" e possui a mesma inclinação a "gastar bens alheios" "193. Passa por justo, por força de um prodigioso autodomínio por conta do exercício da avareza, e "reprime

\footnotetext{
${ }^{190}$ Rep. VIII 552b-e.

191 Rep. VIII 554a-b: “- Acaso não se parecerá com ela [a oligarquia], antes de mais, na importância máxima que confere às riquezas? - Pois não! - Além disso, em ter um espírito econômico e operoso, que se limita a satisfazer as suas necessidades prementes, sem proporcionar quaisquer outros gastos, escravizando os restantes desejos como vaidade."

192 Rep. VIII 553b-d.

${ }^{193}$ Rep. VIII 554d.
} 
outros desejos maus que tem"; porém faz isso sem nem ao menos tentar suavizar estes últimos, uma vez que não está convencido de que não se deve buscá-los, mas simplesmente teme perder sua fortuna ${ }^{194}$. Tal como seu pai, o oligarca está cindido em dois, não havendo harmonia e concórdia entre as partes de sua alma; entretanto, diferente daquele, já não há nele qualquer reminiscência da beleza da aristocracia - sua divisão não é entre a honra pública e os prazeres privados, mas entre estes últimos, que ele refreia, e a avareza.

A valorização e o desejo ilimitado de riquezas destroem a temperança e arruínam o regime. Os governantes, interessados apenas em aumentar ainda mais os seus haveres (por meio de empréstimos a juros) e, em decorrência, o seu prestígio, hesitam em tomar medidas que impeçam que os jovens esbanjadores dilapidem seus bens. A permissividade dos governantes e a entrega dos jovens aos prazeres fazem com que cresçam o ganho pelos juros e o número de endividados.

É assim que, nas oligarquias, descurando e consentido na libertinagem, algumas vezes reduziram à penúria homens de estofo não destituído de nobreza. (...). Ora estes são, julgo eu, os que ficam na cidade, providos de ferrão e armados, uns com dívidas, outros cheios de ódio, a tramar contra os que adquiriram seus bens e contra os demais, tomados da fúria da revolução... ${ }^{195}$

No momento oportuno, os pobres, reduzidos à miséria e agora em maior número, podendo observar mais de perto, percebem que, diferente do que pensavam, seus governantes não são melhores que eles, o que os leva a se indignarem, fomentando assim a guerra civil, a qual leva à instituição da democracia pelas armas. Uma vez instalada, esta última distingue-se dos governos anteriores em primeiro lugar pelo modo

\footnotetext{
${ }^{194}$ Rep. VIII 554d.

${ }^{195}$ Rep. VIII 555e.
} 
de instituir os governantes: se na cidade ideal os governantes são escolhidos entre os melhores, por sua sabedoria, se na timocracia são escolhidos os impetuosos por se passarem por justos e na oligarquia os mais ricos garantem que só eles governem pelo critério do censo, na democracia a escolha é pelo sorteio.

Esta diferença no processo de escolha dos governantes está ligada à característica mais evidente da democracia, que é a instauração da mais plena liberdade, havendo absoluta licença para cada um organizar a própria vida como bem lhe aprouver. Com isso, nesta forma de governo acaba por encontrar-se uma grande variedade de gêneros humanos, assim como de constituições. Ademais, vigora nela uma grande indulgência a respeito da coisa pública ou dos negócios privados, assim como um desprezo pela formação das crianças e dos jovens nas coisas belas, pois como tudo parece igual, não há distinções entre os diferentes valores e gêneros de vida.

O caráter correspondente a este regime da mesma forma não faz as devidas distinções entre os prazeres necessários e não necessários ${ }^{196}$ nem entre os diversos valores e atividades. Como acolhe uma parcela dos valores anteriores como parte de seu bazar interior, a nada se entrega inteiramente, mas a cada vez, de acordo com a sorte, dedica, sem muito afinco, seu tempo e trabalho a algo diferente.

- Portanto - continuei eu - passará cada dia a satisfazer o desejo que calhar, uma vezes embriagando-se e ouvindo tocar flauta, outras ainda fazendo ginástica; ora entregandose à ociosidade e sem querer saber de nada, ora parecendo dedicar-se à filosofia. Muitas vezes entra na política salta para a tribuna e diz e faz o que adregar. Um dia inveja os militares, e vai para esse lado, ou os negociantes, e volta-se para aí. Na vida dele, não há ordem nem necessidade; considera que uma vida destas é doce, livre e bem-aventurada, e segue-a para sempre ${ }^{197}$.

\footnotetext{
${ }^{196}$ Cf. Rep. VIII 558d-e,559a-d.

${ }^{197}$ Rep. VIII 561 d-e.
} 
Percebe-se que o princípio da divisão do trabalho, que norteia a cidade justa, foi subvertido pelo democrata. Na verdade, trata-se de um caráter em que nenhum valor e nenhum princípio ordenador se estabeleceram verdadeiramente em sua juventude. Como não preza tanto as riquezas, por não tê-las adquirido por $\mathrm{si}^{198}$, o oligarca não fincou raízes no seu interior. Como ainda, por incúria de seu pai, não teve nenhuma instrução na juventude, nenhuma boa tintura deixou marcas indeléveis no seu caráter. A alma assim "vazia de ciência, de hábitos nobres e de princípios verdadeiros" "199, quando ainda na juventude encontra zangões que lhe permitem experimentar a doçura dos prazeres não necessários (que até então lhe negava a contenção de seu pai), "principia nele a mudança do oligárquico que nele existe para o democrático". ${ }^{200}$

Mas se um democrata segue toda a sua vida desta maneira, o mesmo não ocorre com a democracia. Assim como na oligarquia o excessivo valor conferido às riquezas a põe a perder, na democracia o ápice da liberdade converte-se em escravidão. Vejamos como isto ocorre.

A permissividade da democracia (que se verifica também no democrata), a indulgência, a aversão a qualquer contenção ou ordenamento, a incúria com relação à coisa pública, tudo isso leva a que os chamados zangões, surgidos no regime anterior, obtenham uma proeminência no governo, que em outro regime não conseguiriam.

Platão enumera além desta classe de homens, os zangões, mais duas na democracia: a dos ricos e a composta por trabalhadores e possuidores de pequenas posses. Como os zangões são tipos preguiçosos e perdulários acabam por procurar esbulhar os bens alheios. Não sendo possível retirar de quem nada tem, iludem estes que são em maior número com promessas e lisonjas, persuadindo-os deste modo de sua

\footnotetext{
${ }^{198}$ Rep. I 330c.

${ }^{199}$ Rep. VIII 360e.

${ }^{200}$ Rep. VIII 559e.
} 
empresa de despojar de suas posses aqueles que as têm em abundância. Uma vez repartido o butim, elevam um destes a “protetor do povo". Mas, uma vez instalado, este, no entanto, se põe a fazer a guerra, para que sempre pareça necessário. Sempre desconfiado, melindra-se à menor crítica e não se peja de se livrar de maneira injusta dos amigos e dos inimigos. De zangão que era, torna-se lobo. Livra-se dos prudentes e dos corajosos e se cerca de aduladores, mantendo o povo escravo e miserável.

Podemos observar por este percurso que, quanto mais os prazeres proporcionados pelo luxo e pelas riquezas se ampliam, mais degenerados os governos se tornam, verificando-se também um afastamento progressivo da razão. Em contrapartida, dos prazeres furtivos do timocrata até os desregramentos sem peias da tirania, os homens se tornam piores, mais voltados para os próprios interesses em detrimento da cidade. A cidade ideal, que era una, primeiro se duplica com a oligarquia para em seguida se fragmentar com a democracia. Aos poucos, insidiosamente surgem aqueles que gastam os bens alheios e entesouram os seus: o timocrata e o oligarca. Em seguida, aparecem aqueles que esbanjam e dissipam sem distinção tudo o que estiver ao seu alcance, primeiro os próprios bens, depois os dos outros: os zangões.

Percorrido o caminho do vício, agora é possível vislumbrar a cidade ideal platônica por um ângulo um pouco diferente. Esta, que nunca chegou a se concretizar (diferente de alguns dos regimes viciosos), pode ser vista como um constructo pensado como uma forma de se compreender a origem da doença do corpo político, ao mesmo tempo em que um modelo para se examinar as vias necessárias para o enfrentamento de tal doença. De fato, ao examinarmos os meandros de cada regime vicioso e do caráter 
correspondente, após a descrição da cidade ideal, é possível identificar pelo afastamento do bem (a medida), onde surge o vício e de que modo. É a medida da cidade ideal que permite que Platão afirme, no livro IX, que a timocracia é o menos afastado do ideal ${ }^{201}$.

Ao proceder assim, Platão teria realizado pela primeira vez no âmbito da filosofia o recorrente exercício grego de reflexão a respeito do modelo de melhor cidade e, nesta tentativa, teria seu sucessor mais destacado na figura de Aristóteles, o qual, como se sabe, aborda esse tema na Política. De fato, George Logan considera que

a Política de Aristóteles é a obra culminante da breve e brilhante tradição que se origina com a República de Platão, a teoria da cidade-estado. Nesta tradição a teoria política primeiro se torna um ramo da filosofia especulativa, logicamente conectada com a ética, mas tendo suas próprias preocupações distintas. O vínculo entre a ética e a política é fornecido pelo conceito de autarquia. A ética tem suas bases na psicologia e na fisiologia, as quais esclarecem a natureza do homem. Dada esta natureza, a questão central da ética é a determinação da melhor vida para o indivíduo. A ética leva para a política porque, como Platão diz "o indivíduo não é autossuficiente, mas tem muitas necessidades que não pode suprir por si mesmo" (Rep. II 369b). A questão original da filosofia política é, então, a determinação da melhor forma de polis; quer dizer da configuração dos recursos humanos e materiais que constituirão uma unidade autossuficiente e produzirá assim para os cidadãos a felicidade que não podem alcançar isolados uns dos outros. ${ }^{202}$

A melhor república em Platão e Aristóteles deve ser entendida como um sistema racional, uma estrutura completamente integrada, em que, por conta das relações recíprocas, uma parte não pode ser destacada da outra. Como vimos, em Platão a autarquia só pode ser atingida se os particulares concordarem em cooperar entre si e desempenharem da melhor maneira possível as tarefas em que de fato são melhores. Neste sentido, a vida mais feliz é aquela dedicada ao melhor funcionamento do todo de acordo com a razão. O todo mais racional é aquele que melhor impede de prosperar

\footnotetext{
${ }^{201}$ Rep. 387c

${ }^{202}$ Logan, The meaning of More's Utopia, pg. 87.
} 
homens que, voltados unicamente para o desejo cego e o autointeresse, ao invés de contribuir para o todo, fomentam a divisão e dilapidam as bases da autarquia. A medida da autarquia é um conhecimento fornecido a partir da razão, cujo desenvolvimento atinge o seu ápice no filósofo.

Mas há aqui ainda outro aspecto importante. Com efeito, como dissemos antes, o percurso constituído por toda a reflexão política desenvolvida por Platão ao longo da República, apesar da referência prática imediatamente presente, é orientado por um critério eminentemente metafísico que lhe dá seu sentido específico - afinal, o critério máximo pelo qual se orienta o filósofo é o Bem, objeto real de toda a sua formação, e contemplado apenas ao final dela, permitindo então que se apreenda o sentido de todo o universo e, com isso, da vida humana em seu interior, e da própria comunidade. Ora, em Aristóteles já é possível observar-se outro direcionamento. Embora a comunidade política tenha, também para ele, um sentido metafísico na medida em que garante a perpétua reprodução da espécie humana (por meio da qual esta se aproxima da divindade), ocorre que Aristóteles censurava Platão pelo fato deste, no delineamento de sua cidade ideal, não se preocupar com sua viabilização efetiva.

A mudança de perspectiva de Aristóteles com relação a seu antecessor pode ser notada logo na frase que abre o livro II da Política, no qual são formuladas as críticas à República. De fato, ali Aristóteles diz que "nosso propósito é considerar qual forma de comunidade política é a melhor de todas para aqueles que são mais capazes de realizar seu ideal de vida"203. Diferente, portanto, de Platão, para quem a possibilidade de realização da concepção ideal não era a questão central, Aristóteles tem em vista também este problema. Em função disso, ele procura realizar um exame tanto das constituições existentes em cidades reais e que eram vistas como bem governadas,

${ }^{203}$ Polit. II,1, 1260b 25, grifo meu. 
quanto das formas teóricas em geral admiradas, conjunto em que inclui a República em primeiro lugar.

$\mathrm{Na}$ Utopia, porém, a perspectiva metafísica desapareceu por completo. Não há nenhum bem último transcendente a ser alcançado pelo filósofo no final da investigação, no qual ele deveria procurar a medida necessária para dirigir a república $^{204}$. Por isso, não há no livro nenhuma alegoria de um processo de conhecimento ascendente e nenhuma fábula que dê conta da estrutura do universo. Nem mesmo um conceito abstrato de justiça é buscado. No diálogo entre Giles, More e Hitlodeu não há progressão a partir do consenso dos interlocutores e as discordâncias não constituem desvios para melhor se obter a ciência. Ao contrário, os diferentes pontos de vista são mantidos enquanto tais até o final. A cidade ideal nos é apresentada como se existisse de fato e, a não ser pelo ato inaugural de Utopos, jamais acompanhamos a sua construção lógica tendo Hitlodeu como guia. Ao contrário, o diálogo se interrompe justamente no relato da cidade imaginada e é retomado somente no final. A cidade de Platão sempre foi um construto abstrato, uma cidade de palavras, e nunca se apresentou como diferente disso; a de More se reafirma na sua concretude, tendo sido, como sabemos, forjada pelo trabalho.

\footnotetext{
Vtopia priscis dicta, ob infrenquentiam,

Nunc ciuitatis aemula Platonicae,

Fortasse uictrix, (nam quod illa literis

Deliniauit, hoc ego uma praestiti,

Viris \& opibus, optimasque legibus)

Eutopia mérito sum uocanda nomine $\mathrm{e}^{205}$.
}

Utopia, em razão do isolamento, pelos antigos assim chamada,

\footnotetext{
${ }^{204}$ Muito embora, como veremos, os utopianos assentem sua filosofia moral em princípios religiosos e numa ordenação racional da natureza, determinada por Deus.

${ }^{205}$ Utopia, pg. 20.
} 
Agora êmula da cidade de Platão

Talvez a ela superior, pois aquilo que ele em letras

Delineou, eu, de uma só vez, o apresentei

Com homens, bens e leis maravilhosas.

Eutopia, há bom título, a que chamar. ${ }^{206}$

Cabe observar, além disso, que em momento algum More realiza uma discussão que se assemelhe àquela desenvolvida por Platão, começando pela investigação sobre em que consistiria o melhor gênero de vida para o indivíduo, daí passando para o exame dos objetivos comuns cuja consecução resultaria na felicidade dos cidadãos, seguindose então para a catalogação dos componentes físicos e institucionais necessários à cidade, para daí chegar finalmente à organização dos mesmos, de modo a se produzir a melhor república. Em lugar disso, o que temos é a apresentação direta de um modelo que incorporaria aqueles que seriam os resultados finais desta discussão ausente.

Assim, a Utopia apresenta alguns embaraços a quem queira interpretá-la como uma simples imitação da República, embora haja evidências de que More a utiliza como uma referência fundamental para pensar suas próprias questões. Uma melhor determinação deste problema exige que sejam examinados certos detalhes. E, apesar das diferenças, alguns autores encontraram paralelismos entre as duas obras, demonstrando que a República é fonte para certos princípios presentes na Utopia.

Em seu estudo que serve de apresentação da tradução da Utopia publicada pela Universidade de Yale, Surtz confronta certas semelhanças e mostra que alguns princípios e detalhes não aparecem exatamente da mesma forma em Platão e More. Isto ocorre porque "este último sempre muda e torce seus empréstimos de forma que eles pareçam se encaixar perfeitamente no Estado ideal que parece fornecer a resposta para

\footnotetext{
${ }^{206}$ Vtopia, pg. 207.
} 
os problemas contemporâneos"207. Mas, mesmo assim, Surtz vê a forma de diálogo do Livro I como uma "contribuição platônica à Utopia"208 . Ainda, segundo ele,

[o]s interlocutores em ambos os livros, a República e a Utopia, se dirigem a uma residência privada após uma cerimônia religiosa em um porto. $\mathrm{O}$ objeto de ambas é a "ideia" de uma república, embora a "ideia" utopiana pareça mais praticável devido à sua relação com as circunstâncias e problemas contemporâneos. A Utopia pinta um estado como já existente; a República, como sendo formado. Ambas as criações, porém, são tão perfeitas que há pouco espaço para desenvolvimento e melhoria ${ }^{209}$.

Tomando em consideração o início desta "contribuição platônica" já podemos verificar que existem certas diferenças significativas. $\mathrm{O}$ que se segue ao encontro dos personagens na cidade portuária de Antuérpia são os pedidos de More para que o viajante relate suas experiências no novo mundo, sobretudo a respeito de cidades bem ordenadas, cujas instituições poderiam servir de modelo para Inglaterra. Alguns destes relatos impressionaram de tal modo Peter Giles que este interrogou o viajante-filósofo acerca das razões pelas quais ele não integrava o conselho de um rei (uma questão eminentemente prática, portanto). No caso da obra platônica, porém, como dissemos, a investigação da justiça se apresenta sob o signo da busca pela verdade. A discussão dialética é posta em movimento ali nos moldes tradicionais de pergunta e resposta, com Sócrates propondo uma questão inicial à qual o interlocutor responderá fornecendo uma definição provisória, que deverá então ser problematizada novamente. O desenvolvimento lógico desta discussão (que inclui o desvio de Trasímaco) desemboca na ordenação da república. Em contraste, como apontamos, na obra de More a perspectiva é diretamente política e não passa pela investigação conceitual. As

\footnotetext{
${ }^{207}$ Surtz, E. Sources, parallels, and influences, In: Utopia, pg. clvii.

${ }^{208}$ Surtz, E. Sources, parallels, and influences, In: Utopia, pg. clvii.

${ }^{209}$ Surtz, E. Sources, parallels, and influences, In: Utopia, pg. clvii.
} 
intervenções do filósofo se dão tendo em conta seus conhecimentos, mas também sua experiência como viajante. Ele não questiona, e sim, discute, argumenta, defende seus valores e apresenta alternativas a partir das nações que visitou.

Ainda que consideremos o debate que se inicia em torno da participação do filósofo no conselho de príncipes, não há nenhuma tentativa de definição do que deveria ser entendido pelos termos "filósofo" e "verdadeiro príncipe". Nem mesmo há dúvidas a respeito de se a Inglaterra ou os governos da Europa são bons ou maus. Na verdade, neste quesito o consenso entre Giles, Hitlodeu e More parece já estar dado de antemão.

Se levarmos ainda em conta que, conforme demonstrou J. H. Hexter, a obra foi concebida originalmente sem o chamado Diálogo do Conselho, ou seja, sem a maior parte do Livro I (que é a parte propriamente dialogada), e sem o final do Livro II (que compreenderia a peroração de Hitlodeu e a última seção, a qual retoma e fecha o diálogo), é possível notar que a Utopia está de fato um pouco mais distante de seu pretendido modelo. $^{210}$

E se na estrutura geral do livro e no próprio diálogo (posteriormente acrescentado) nos deparamos com diferenças significativas com relação à República, isto também acontece no que se refere a tópicos específicos. O traço que mais evidentemente aproxima as duas obras é o comunismo. Porém, na Utopia ele é o princípio organizador de toda a cidade, enquanto que na República ele se restringia às

\footnotetext{
210 "Em resumo, então, propomos o seguinte esquema de composição para a Utopia: umas poucas linhas prefaciatórias, o Livro I do final do parágrafo curioso em diante, e a seção de conclusão do Livro II escritos em Londres algum tempo depois do retorno de More de sua missão na Holanda; o resto escrito antes, provavelmente enquanto More estava aguardando, na Holanda, que os conselheiros de Carlos tomassem as decisões de que a missão dependia. Esta análise é, em alguma medida, confirmada tanto pela estrutura geral quanto pela forma da Utopia. Estruturalmente a transição direta do parágrafo curioso para o Livro II é simples e natural, não envolvendo nada da artificialidade forçada que notamos na organização da obra final publicada. Quanto à forma, um escritor observa, "um fato foi ignorado por quase todos os comentadores da Utopia; e é o fato de que ela foi escrita na forma de um diálogo", segundo o modelo da República de Platão. A mim parece que este fato não é de modo algum um fato. O Livro II até a seção de conclusão, e isto significa dois terços de toda a obra, é qualquer coisa menos um diálogo; é um discurso ininterrupto de Hitlodeu sobre a república utopiana". Hexter, J.H. More's Utopia the biography of an idea, pg. 26-27.
} 
classes dirigentes e protetoras. Para extrairmos uma compreensão mais acurada deste traço central que marca a semelhança e também a diferença entre ambas, é preciso analisar outro empréstimo que More faz a Platão. Trata-se do principal mal da república, aquele que analisamos anteriormente: os zangões.

Há um grande número de fidalgos que não só passam a vida na ociosidade, como zangãos atidos ao trabalho de outros, mas ainda por cima, para aumentarem os seus rendimentos, sugam os seus trabalhadores até ao sangue vivo. É de facto o único tipo de frugalidade que conhecem, pois, quanto ao resto, são tão esbanjadores que caem na mendicidade; de verdade, trazem à sua volta uma grande multidão de parasitas sem terem nada para fazer que nunca aprenderam qualquer ofício para ganharem a vida ${ }^{211}$.

Neste trecho, por ocasião do diálogo na casa do Cardeal Morton, Hitlodeu praticamente utiliza os mesmos termos pelos quais Platão se refere à doença que aflige a oligarquia.

- Nisso a oligarquia é a primeira a incorrer. - Certamente que tal situação não encontra impedimento numa oligarquia. Se assim não fosse, não haveria quem fosse rico em excesso, nem completamente privado de recursos. (...) - Repara, pois, no seguinte: quando uma pessoa nessas condições [que não toma parte em nenhuma atividade], no tempo em que era rica, gastava sua fortuna, acaso era então mais útil à cidade, relativamente às atividades que referimos? Ou parecia tomar parte dos governantes, quando na verdade não era chefe, nem servidor do Estado, mas dissipador dos seus haveres? $?^{212}$

Assim como Sócrates, na República, o filósofo na Utopia localiza na existência de uma classe inativa e perdulária a origem do roubo e da mendicância, os quais, ao lado das guerras, configuram alguns dos principais males que afligem a república. Mesmo o que ele chama de problema específico da Inglaterra, as ovelhas que se

${ }^{211}$ Utopia, pg. 62; Vtopia, pg. 245.

${ }^{212}$ Rep. $552 \mathrm{~b}$ 
comportam como as Cilas e os Lestrigões, na verdade, tem a mesma origem e nada mais é do que um agravamento do problema anterior.

Não é esta apenas a causa da ladroagem; existe uma outra que, quanto creio, é mais específica do vosso país. (...) Acontece que em qualquer local do reino em que se produz lã mais fina e por isso mesmo mais cara, aí caem os senhores de alta e baixa nobreza e até abades, alguns deles santos varões, que não se contentam com os rendimentos e colheitas anuais, que costumavam ser cobrados pelos seus predecessores sobre os prédios: não tendo o suficiente para viverem à grande, na ociosidade, já não se incomodam com a utilidade pública, a não ser que os prejudique, nada deixam no campo, tudo delimitam com pastagens, fazem demolir as casas, arruínam os povoados, deixando só a igreja para estábulo das ovelhas e, como se fosse apenas perder um pouco de terreno no vosso meio, com coutos de caça e as suas reservas, esses homens de boa condição transformam em deserto todos os lugares habitados e tudo o que até agora era de cultivo ${ }^{213}$.

A solução na qual "More" insiste é a participação do filósofo no conselho de reis, chamando Platão em seu socorro. "Se é verdade que, como pensa o teu querido Platão, os estados hão-de algum dia encontrar a felicidade, quer sejam os filósofos a reinar quer sejam os reis a filosofar, quão longe ficaria a felicidade se os filósofos não se dignassem a repartir os seus conselhos com os reis!" ${ }^{214}$. Ao que Hitlodeu contrapõe a experiência de Platão junto à corte de Dionísio, mas não sem antes introduzir um pequeno ajuste na citação que More faz da República: “mas não há que duvidá-lo, bem o prognosticou Platão: se os reis não forem eles próprios filósofos, dado que desde crianças se deixam imbuir e corromper por doutrinas perversas, nunca eles alguma vez

\footnotetext{
${ }^{213}$ Utopia, pgs. 64-66; Vtopia, pg. 248.

${ }^{214}$ Utopia, pg.86; Vtopia, pg. 266. Também Rep.V473d: "Enquanto não forem, ou os filósofos reis nas cidades, ou os que agora se chamam reis e soberanos filósofos genuínos e capazes, e se dê esta coalescência do poder político com a filosofia, enquanto as numerosas naturezas que actualmente seguem um destes caminhos com exclusão do outro não forem impedidas forçosamente de o fazer, não haverá tréguas dos males, meu caro Gláucon, para as cidades, nem sequer, julgo eu, para o gênero humano, nem antes disso será jamais possível e verá a luz do sol a cidade que há pouco descrevemos. Mas isto é o que eu há muito hesitava em dizer, por ver como seriam paradoxais essas afirmações. Efectivamente, é penoso ver que não há outra felicidade possível, particular ou pública."
} 
hão-de comprovar inteiramente os conselhos dos que se entregam à filosofia." ${ }^{215}$ Embora "More" se refira corretamente à República, Hitlodeu acrescenta uma precisão que havia escapado a ele, e que a própria experiência de Platão comprovara: de nada adianta que os filósofos repartam seus conselhos com os reis, estes últimos não ouvirão se não forem eles próprios filósofos - por onde Hitlodeu se mostra mais fiel ao espírito da obra, minando a argumentação de "More". Esta correção não é sem consequências para o significado da república ideal que ele mesmo afirma ter conhecido, nem para a caracterização do seu narrador. Chama ainda a atenção o fato de que quem incorreu em incompreensão foi "More", não Hitlodeu. Quer o autor de Utopia dizer com isso que o verdadeiro filósofo é Hitlodeu? Talvez seja exagero afirmá-lo, mas ao menos ficamos sabendo que este último leu melhor a República. Além disso, as experiências mal sucedidas do autor da República como conselheiro na corte do tirano de Siracusa (que não somente foram infrutíferas, mas quase custaram a vida do filósofo) fortalecem o argumento de Hitlodeu, ao passo que a estas experiências "More" não contrapõe nenhuma outra.

As considerações de Platão na Carta Sete acerca de seu período na corte de Dionísio corroboram a recusa de Hitlodeu:

Depois disso, fiz nova viagem e voltei à Sicília, em atenção aos insistentes chamados de Dionísio. Quais fossem minhas intenções e como procedi por maneira razoável e justa, é o que só vos direi depois de aconselhar-vos sobre o que importa fazer na presente conjuntura. (...) Quem tivesse de aconselhar a algum doente submetido a dieta prejudicial à saúde, não precisaria, antes de mais nada, mudar o seu regime? Mas, ante a obstinação formal do doente, terei na conta de homem direito e de verdadeiro médico quem se negasse a dar-lhe novas consultas, e o contrário disso, cobarde e ignorante da arte quem cedesse nalgum ponto de suas convicções. O mesmo se verifica com as cidades, quer sejam dirigidas por um homem apenas, quer por muitos. Quando o governo avança no caminho indicado pelas instituições e solicita algum parecer sobre

${ }^{215}$ Utopia, pg. 86; Vtopia, pg. 267. 
questões de utilidade pública, é dar prova de cordura executar o que ele pede. Mas, as cidades que se afastam inteiramente das instituições sadias e se recusam em absoluto seguir-lhes as pegadas, com ordenarem aos conselheiros que deixem a constituição tranquila e não a tirem do lugar, sob pena de morte se tal fizerem, e só desejem que todos se dobrem a seus caprichos e paixões e lhes indiquem os meios mais rápidos e fáceis de satisfazê-los no futuro: consideraria desbriado quem se sujeitasse a dar conselhos em semelhantes condições, e o contrário disso, valoroso, quem se recusasse a fazê-lo ${ }^{216}$.

$\mathrm{Na}$ sequência do diálogo, Hitlodeu pede para que "More" imagine duas situações: em primeiro lugar, que ele, Hitlodeu, estivesse no conselho do rei da França; em segundo lugar, que estivesse no conselho de um rei qualquer. Nos dois casos o rei e seus conselheiros estão discutindo sobre dois dos grandes males da república: a guerra e o dinheiro ${ }^{217}$. No primeiro o rei está se preparando para a guerra e os conselheiros estão pensando em maneiras de ludibriar aliados e inimigos; no segundo, os conselheiros discutem maneiras que deem ao rei "capacidade de acumular bens para o tesouro"218. Os conselheiros recomendam diversos expedientes desonestos ${ }^{219}$ para espoliar a população, seja através de impostos, de multas ou da manipulação do valor da moeda. Para o que nos interessa aqui, porém, merece destaque aquele acerca do trato com os juízes:

De facto não hão-de faltar pretextos ao magistrado para se pronunciar em favor do príncipe: na realidade, basta-lhe invocar ou a equidade ou os termos da lei ou o sentido retorcido de um texto ou, enfim, a interpretação dominante das leis por parte de juízes ditos escrupulosos em favor de prerrogativas indiscutíveis do príncipe. (...) Aliás, um rei nunca pode cometer injustiça, mesmo que o quisesse com todas as suas capacidades; é que tudo o que é de todos a ele pertence, mesmo que sejam as pessoas; ao passo que cada um só tem de seu o que a benignidade do rei não retira; mesmo que isso seja mínimo, ao rei não pode tal coisa deixar de interessar, uma vez que a sua segurança assenta no facto de o povo não poder usufruir de riqueza e liberdade, pois estas dão azo a não suportar com suficiente resignação um governo duro e falho de justiça, ao passo

\footnotetext{
${ }^{216}$ Platão, Carta Sete 330c-331a In: Diálogos, vol. V, trad. Carlos Alberto Nunes.

${ }^{217}$ No jantar na casa do Cardeal Morton, são também estes dois problemas que Hitlodeu discute. Cf. Utopia, pgs. 59-71; 87-97; Vtopia, pgs 242-252; 267-276.

218 Utopia, pg. 94; Vtopia,pg. 274

219 Embora Hitlodeu se refira à situação como imaginária, parte dos conselhos descritos no texto foram políticas efetivamente implementadas por Henrique VII na Inglaterra.
} 
que a miséria e a falta de meios amansa os espíritos, torna-os passivos e retira aos oprimidos o ímpeto de espírito que os levaria a revoltarem-se $\mathrm{s}^{220}$.

Estes conselhos são afins com os atos do tirano tais como são descritos e analisados por Platão na República. Trata-se de aumentar os tesouros com os expedientes inescrupulosos à disposição, inclusive julgamentos viciosos, a fim de retirar as posses da população e reduzi-la à miséria e à impotência. Pois, como aponta Sócrates, não seria bom para o tirano que "os que ficaram pobres pagando impostos sejam forçados a dedicar-se ao dia a dia e conspirarem menos contra ele?"221

A contraposição imaginada por Hitlodeu caso ele pertencesse a este conselho se aproxima muito de formulações encontradas em trechos da República.

\begin{abstract}
Neste momento, se eu me levantar mais uma vez e porfiar em dizer que se dão ao rei todos estes conselhos, mas que eles são desonestos e perniciosos e que não só a sua honra mas até a sua segurança está mais nas riquezas do povo do que nas suas, se eu demonstrar que os cidadãos escolhem um rei para seu bem e não para o bem do rei, ou seja, com o objectivo de viverem tranquilamente no seu trabalho e nas suas preocupações, livres de serem maltratados, e que por isso ao príncipe pertence sobretudo cuidar que o seu povo esteja bem, mais do que ele mesmo, como é próprio do ofício de pastor que, como tal, deve apascentar as ovelhas mais do que a si mesmo... ${ }^{22}$
\end{abstract}

Seguindo o percurso dos males que afligem a cidade de maneira semelhante ao que havíamos feito em nosso exame da República é possível notar na Utopia o uso de termos muito próximos àqueles utilizados por Platão, além de um diagnóstico paralelo no que se refere às doenças que atingem o corpo político da Inglaterra contemporânea, tal como no caso, por exemplo, dos parasitas que vivem ociosamente, dilapidando as

\footnotetext{
${ }^{220}$ Utopia, pg. 94; Vtopia, 2015, pg. 274. Cf. também Aristóteles, Política V, 11,5-21: "é característica do tirano deixar os súditos na pobreza, de tal modo que, ficando ocupados com as tarefas diárias, não tenham tempo disponível de conspirar contra o seu soberano."

${ }^{221}$ Rep. VIII 567a

${ }^{222}$ Utopia, pg. 94; Vtopia, pg. 274-275.
} 
posses da população e cometendo injustiças. Se More adapta os empréstimos que faz de Platão a seus propósitos (e de fato ele o faz), é porque o modo como estes problemas se apresentam traz em si mesmo importantes semelhanças, ainda que isso não os torne exatamente idênticos.

O personagem More não parece discordar do diagnóstico de Hitlodeu no que respeita aos problemas que ele observa na república e nas cortes, já que em nenhum momento ele apresenta qualquer objeção ou mesmo alguma interpretação alternativa. As discordâncias no diálogo do Livro I aparecem com relação à não-participação do filósofo no conselho, aos motivos elencados por Hitlodeu e, posteriormente, também com relação à comunidade de bens e à abolição da propriedade privada. Tais objeções são formuladas em termos que situam a personagem More no debate como representante da tradição latina, na qual o filósofo é chamado a participar nos negócios públicos como um dever de ofício, maneira apropriada de unir o útil e o honesto.

Quanto ao mais, não posso, de forma alguma, alterar o meu parecer; pelo contrário, estou plenamente convencido de que se tiveres a coragem que te é própria e não puseres de lado a tua presença nos palácios dos príncipes, poderás com os teus conselhos ser de grande utilidade, pois nada mais incumbe ao teu ofício que o de um homem que faz o bem $^{223}$.

Ainda quando ele concorda com Hitlodeu em que não há lugar para a filosofia nas cortes, ele faz um reparo no qual defende a necessidade do decorum aconselhado por Cícero tanto no De Oratore quanto no De Officiiss ${ }^{224}$ :

\footnotetext{
223 Utopia, pg. 86; Vtopia, pg. 267.

${ }^{224}$ De Officiis I (31): "Frequentemente surgem ocasiões em que as ações que parecem mais adequadas a um homem justo, ou àquele a quem chamamos de bom, sofrem uma mudança e se tornam o oposto. Por exemplo, de tempos em tempos se torna justo deixar de lado exigências tais como devolver aquilo que lhe foi confiado, ou cumprir uma promessa, ou outras coisas relacionadas à verdade e à boa fé, e não observálas, pois é aparente que elas deveriam ser referidas àqueles fundamentos de justiça que eu estabeleci no início: primeiro que não se deve prejudicar ninguém; e segundo que deve se servir ao bem comum. Tais ações alteram-se com as circunstâncias, e o dever altera-se igualmente, e não é invariável".
} 
- É justamente isso o que eu diria: junto dos príncipes não há lugar para a filosofia.

- Sim, retorqui, é verdade; não há lugar para ensinar filosofia que se considere servir para tudo e em toda a parte, mas há uma outra modalidade de filosofia (philosophia ciuilior), mais informada da vida em sociedade, que sabe bem o seu papel e que se ajusta bem a ele na peça que está a ser representada, que mantém o seu lugar com equilíbrio e dignidade. Dessa nos devemos $\operatorname{servir}^{225}$.

"More" desenvolve então a analogia teatral ensaiada neste trecho, a fim de tornar clara a sua posição. No entanto, a caracterização da corte como comédia não deixa de causar estranhamento, na medida em que não se harmoniza bem com as noções de equilíbrio e de dignidade:

(...) quando se representa uma comédia de Plauto e os escravos trocam momices entre eles, será que alguém se chega ao proscênio em trajes de filósofo para recitar um passo da Octávia, em que Sêneca discute com Nero, e não seria melhor que fizesse de personagem muda do que urdir uma tragicomédia qualquer recitando um passo estranho? $?^{226}$

Nestes termos, ele indiretamente acaba por concordar com Hitlodeu em que o contexto da corte assemelha-se mais a uma comédia, como ficou claro pelo relato da rusga entre o frade e o parasita ${ }^{227}$ na casa do Cardeal Morton, bem como pelas tentativas infrutíferas de Hitlodeu de persuadir os aduladores que cercavam o cardeal. Quando More entra a argumentar sobre os negócios de Estado, ele defende que, na impossibilidade de erradicar "opiniões deturpadas" e "abusos inveterados", seja tomado o caminho da mediania: nem abandonar os negócios públicos nem impor uma opinião pouco habitual, mas, diz ele, "ao contrário há que se tentar, mesmo com algum esforço, seguir um percurso menos directo, por tal forma que, enquanto isso estiver na nossa

\footnotetext{
${ }^{225}$ Utopia, pg. 98; Vtopia, pg. 278, grifo meu.

${ }^{226}$ Utopia, pg.98; Vtopia, pg 278.

${ }^{227}$ Utopia, pgs. 80-84; Vtopia, pg.262-265.
} 
mão, tudo seja tratado positivamente e que aquilo que não pode ser dirigido para o bem veja o mal ser reduzido ao mínimo" 228 .

Na longa resposta de Hitlodeu que finaliza o diálogo do livro I, por mais três vezes Platão é mencionado e em duas destas menções seu nome é associado à ilha de Utopia e à abolição da propriedade privada, apresentada como solução para os vícios anteriormente diagnosticados. A refutação se apoia nas três partes da argumentação apresentada por "More". No que respeita às opiniões "pouco frequentes e pouco habituais", Hitlodeu diz que se ele procura "dizer a verdade é preciso que diga tais palavras", mesmo que sejam desagradáveis, ainda mais se quiser chamar a atenção para os perigos. Além disso, completa o marinheiro-filósofo, coisas estranhas e pouco habituais também disseram Platão e Cristo.

Se dissesse o que Platão imagina na sua República ou o que praticam os utopienses na deles, mesmo que isso fosse melhor (e por certo é), haveria de parecer coisa estranha, pois aqui a propriedade privada é de cada indivíduo, ali tudo é coletivo. (...) $\mathrm{Na}$ realidade, se há que deixar de dizer tudo o que não é habitual e menos razoável, tudo o que faz parte de comportamentos perversos dos homens, já que poderá parecer estranho, haverá também que encobrir muita outra coisa entre os cristãos - tudo aquilo que Cristo ensinou e que até mandou expressamente que não se deixasse encoberto, como aquilo que disse privadamente aos discípulos e que mandou apregoar em cima dos telhados. A maior parte das suas palavras são mais estranhas do que o foram as minhas. ${ }^{229}$

Já no que tange à defesa de "More" de uma atitude de adaptação à peça, buscando uma forma menos direta de atuar, a fim de reduzir os males na medida do possível, Hitlodeu afirma que a corte exige que se aprove sem ambiguidades e "às claras resoluções da pior espécie" e que se subscreva "decretos de efeitos de todo arrasadores". Além disso, quando se é admitido neste meio, das duas uma: ou se será pervertido, ainda que seja o melhor dos homens, ou "na sua integridade e inocência, servirá de

\footnotetext{
${ }^{228}$ Utopia, pg.98; Vtopia, pg 278.

${ }^{229}$ Utopia, pg. 102; Vtopia, pg. 280, grifo meu.
} 
cobertura a malícia e a estultices alheias, de tal modo que muito dificilmente alguém poderá, por via indirecta, levar alguma coisa a tornar-se melhor"230

Por fim, com relação à primeira parte da argumentação de More, em que ele afirma que não se deve abandonar os negócios do Estado, pois que também "na tormenta não há que desistir do navio por não ser possível fazer amainar os ventos" - a esta, Hitlodeu contrapõe outra imagem cunhada por Platão:

De facto, quando veem o povo espalhado pelas praças a deixar-se molhar por chuvas persistentes, sem que eles sejam capazes de convencê-lo a fugir delas e a pôr-se debaixo de abrigo, então, tomarão eles consciência de que nada valerá saírem de casa senão para se molharem com os outros e por isso mais vale manterem-se dentro de casa, satisfeitos por ao menos eles estarem a salvo, já que não podem remediar a estultice alheia ${ }^{231}$.

Assim, Hitlodeu demonstra a inutilidade da participação nos conselhos de reis, pois não há uma só via que tornaria o conselho frutífero. $\mathrm{O}$ fato é que ele considera a questão a partir de outros pressupostos tomados em parte de empréstimo da filosofia de Platão. Como ele próprio diz muito clara e diretamente perto do final do Livro I, a questão fundamental não está na presença ou ausência de boas leis, as quais só poderiam oferecer paliativos (e, mesmo isso, apenas de forma localizada), mas na necessidade de uma profunda mudança social e econômica no sentido já indicado por Platão:

\footnotetext{
${ }^{230}$ Utopia, pg. 102; Vtopia, pg. 281.

${ }^{231}$ Utopia, pg. 102; Vtopia, pg. 281, tradução modificada. A imagem, assim como parte da réplica de Hitlodeu, foi extraída da República VI, 496c-e: “(...) quando viram suficientemente a loucura da multidão, e que ninguém executa nada de sensato, por assim dizer, no governo dos Estados, nem há aliado em cuja companhia pudessem prestar socorro à justiça, ficando a são e salvo, mas antes, como se fosse um homem que tivesse caído no meio das feras, sem querer colaborar nos seus desmandos nem ser capaz de, sozinho, resistir a todo esse bando selvagem, perece antes de poder ser de qualquer utilidade à cidade ou aos amigos, sem vantagem para si mesmo nem para os outros - depois de refletirem em tudo isto, mantêm-se tranquilos e ocupam-se dos seus afazeres, como quem, surpreendido por uma tempestade, se abriga atrás de um muro, do turbilhão de poeira e do aguaceiro levantados pelo vento; eles ao verem os outros alagados em injustiça, sentem-se felizes, se viverem neste mundo puros de injustiça e impiedade, e se libertarem desta vida com boa disposição e animosos, acompanhados de uma pura e formosa esperança."
} 
Na realidade, meu caro More (para te dizer a verdade que levo no coração), me parece que em toda parte em que há propriedade privada, em que todos medem tudo por dinheiro, dificilmente alguma vez aí se poderá chegar a promover a justiça de Estado ou a prosperidade (...). Por tal motivo, quando no íntimo do meu coração ajuízo as sapientes e venerandas instituições da Utopia, onde a governação se exerce tão facilmente e com tão poucas leis, onde a virtude tem prêmio sem que, em igualdade de repartição de bens, deixe de haver abundância para todos, e quando, pelo contrário, com os seus costumes comparo os de tantas nações, onde incessantemente se fazem leis, sem que nenhuma delas seja alguma vez suficientemente perfeita, onde cada um chama seu, em propriedade privada, àquilo a que conseguiu deitar a mão, onde as leis que se constituem cada dia são tantas mas não bastam, (...) quando, digo, considero em mim tudo isso, mais presto homenagem a Platão e menos me admiro de que ele tenha desistido de fazer quaisquer leis para aqueles que recusavam aquelas que ele thes propunha e pelas quais todos os bens seriam repartidos por todos em pé de igualdade ${ }^{232}$.

Thomas White, ao analisar este trecho chega a uma interpretação similar:

De qualquer modo, já que a "mensagem" do assim chamado Diálogo do Conselho é que dar conselhos não é um meio efetivo para se favorecer o bem comum, é justo supor que More deseja sugerir um meio melhor e que ele estrutura o Livro I com isto em mente. Além disso, o lugar central de Platão na discussão de enquadramento fica mais claro quando nos voltamos para aquilo que Hitlodeu aponta como a forma mais importante para se obter o bem comum. Depois de Rafael ter terminado seus reparos a respeito da futilidade do conselho, ele identifica a propriedade privada e o dinheiro como as principais ameaças ao bem comum. Ele elogia o comunismo dos utopianos e o liga a Platão ao notar que o pensador grego "facilmente previu que uma só e única era a via para o bem comum: a igual distribuição de bens". O comunismo platônico é a chave ${ }^{233}$.

White, no entanto, acaba subsumindo a questão ao cristianismo de More e identifica sem maiores considerandos as opiniões de Hitlodeu às do autor de Utopia. Segundo ele, a questão para More seria encontrar meios para "subjugar a maior fraqueza humana: o orgulho". ${ }^{234}$ Assim, a distribuição igualitária dos bens seria a solução institucional encontrada para a eliminação deste que seria a origem de todas as pragas.

\footnotetext{
${ }^{232}$ Utopia, pg. 102 ; Vtopia, pg. 282.

${ }^{233}$ White, Thomas I. "Pride and the Public Good: Thomas More's Use of Plato in Utopia", pg. 340.

${ }^{234}$ White, Thomas I. "Pride and the Public Good: Thomas More's Use of Plato in Utopia", pg. 341.
} 
De fato, na peroração, no final do livro II, encontramos apoio para a sua tese na fala de Hitlodeu:

Para mim nem sequer é questão de duvidar que, fosse por cálculo do interesse de cada um, fosse por autoridade de Cristo Salvador (na sua infinita sabedoria não pode ter desconhecido o que era melhor nem na sua bondade poderia deixar de o aconselhar) não se tivesse empurrado o mundo inteiro, desde há muito e com grande facilidade, a adoptar as leis deste Estado, se não fosse a resistência que opõe um único monstro, $a$ sobranceria (superbia), que é cabeça e fonte de todas as calamidades e que não mede a sua prosperidade pelo seu bem-estar, mas pelo mal-estar dos outros. ${ }^{235}$

Porém, quando White busca a definição de orgulho na Utopia, ele mesmo chama a atenção para um traço peculiar - ela é pensada em termos econômicos e não em termos religiosos como um pecado:

Entretanto, devemos também reconhecer que sempre que Thomas More define o orgulho na Utopia, ele o faz em termos materiais e especificamente econômicos. No início do Livro II More nos diz que o orgulho "conta como uma glória pessoal superar a outros pela supérflua exibição de posses", e na peroração na discussão enquadrante Rafael afirma que "o orgulho mede a prosperidade não pelo seu bem-estar, mas pelo mal-estar dos outros. O orgulho não quereria sequer tornar-se deus se essa condição não lhe proporcionasse mais misérias, através das quais lhe fosse possível dominar e espezinhar, se sua felicidade não brilhasse em comparação com as misérias dos outros, cuja condição de penúria torna mais angustiante e ardente". Quer dizer, More descreve o orgulho em termos de suas manifestações materiais, não do caráter interno da pessoa orgulhosa $^{236}$.

Mas, se observarmos mais atentamente, Hitlodeu não afirma propriamente que as leis utopianas ou suas instituições existem para eliminar o orgulho, mas sim, que este funcionaria como um freio, um entrave para a sua implantação em outras repúblicas.

${ }^{235}$ Utopia, pg. 242; Vtopia, pg. 413, grifo meu.

${ }^{236}$ White, Thomas I. "Pride and the Public Good: Thomas More's Use of Plato in Utopia", pg. 342. 
Trata-se [a sobranceria] de uma víbora infernal que desliza nos corações dos humanos e que não os deixa tomarem melhor caminho de vida, como se fosse uma rêmora que puxa para trás e cria um entrave, que se incrusta com tanta força nos homens que não é possível arrancá-la facilmente. ${ }^{237}$

Talvez o caminho para a compreensão das instituições utopianas seja bastante próximo daquele tomado por White. Na discussão com "More” Hitlodeu afirma que nas "sapientes e venerandas instituições da Utopia (...) a virtude tem prêmio sem que (...) deixe de haver abundância para todos". Traduzidos para os termos da tradição filosófica, pode-se dizer que as instituições utopianas são capazes de unir o útil e o honesto. Deste modo, o orgulho, entendido como ostentação diante da miséria, perde o seu sentido, como vimos na visita dos embaixadores anemólios ${ }^{238}$. Mas o objetivo das instituições é expresso mais diretamente em outra passagem do Livro II, a saber, aquela dedicada às artes e misteres:

De facto, se os cidadãos não veem que haja necessidade, as autoridades não os maçam com ocupações excendentárias, tanto mais que a governação coloca como primeiro objectivo que, sem faltar à satisfação das necessidades de interesse público, a maior parte do tempo se dê a todos os cidadãos a oportunidade de se libertarem da servidão corporal para se cultivarem livremente o espirito. É nisso que consideram situar-se a felicidade da vida (uitae felicitatem). ${ }^{239}$

Seria, portanto, para alcançar a felicidade, entendida como livre cultivo do espírito, que as instituições da Utopia foram estabelecidas. Se as "sapientes e

${ }^{237}$ Cf. Utopia, 1993, pg. 243-245 . Cf. também Vtopia, 2015, pg. 414.

238 "A atitude dos embaixadores na já mencionada "elegantíssima fábula" é caracterizada de maneira muito semelhante aos termos em que é descrito o orgulho na peroração do final do livro: “(...) os anemólios, porque viviam bastante longe e tinham contactos menos frequentes com os utopienses, tendo sido informados de que estes se vestiam todos da mesma maneira e sem requinte, supuseram que não usavam melhores trajes porque os não tinham e, com mais soberba (soperbia) que sabedoria (sapentia), decidiram apresentar-se com o aparato próprio de deuses a fim de encher de assombro os olhares dos pobres utopienses com o esplender dos seus trajes". (foram substituídas as palavras "vaidade" e "sensatez" da tradução portuguesa, por "soberba" e "sabedoria", termos mais literais e mais significativos para a leitura ora proposta.) Cf. Utopia, 1993, pgs 153-157; Vtopia, 2015, pgs. 323-325

${ }^{239}$ Utopia, 1993, pg. 134; Vtopia, 2015, pg. 309, grifo meu. 
venerandas" premiam as virtudes, elas também permitem o seu desenvolvimento, na medida em que libertam os seus cidadãos da servidão do corpo. Entretanto, esta definição de felicidade parece à primeira vista não se coadunar inteiramente com a filosofia moral utopiana. Por outro lado, se examinarmos com cuidado esta última, poderemos obter algumas pistas que permitam precisar melhor o sentido destas mesmas instituições e, assim, avaliar a possível compatibilidade entre ambas.

Segundo o relato de Hitlodeu, a questão moral primária e suprema entre os utopianos diz respeito à felicidade humana, sendo que eles discutem a relação desta com a virtude e o prazer (uoluptas) e, ao tentar defini-la no todo ou na sua parte principal, eles "parecem mais propensos à corrente que defende o prazer (uoluptas)"240. Será que então neste ponto não se verificaria um importante afastamento em relação a Platão? Afinal, para Platão, a preocupação não consiste justamente em colocar o prazer dos sentidos sob a direção, o ordenamento e a medida da razão?

Um caminho possível para se avaliar estas questões poderia talvez ser encontrado na separação do narrador Hitlodeu em relação ao objeto narrado, de modo que Hitlodeu defenderia a comunidade de bens de Utopia nos termos da filosofia platônica, enquanto que os utopianos justificariam sua república em outras bases. Entretanto, a questão é um pouco mais complicada.

Se, de fato, o prazer tem um papel fundamental na moral utopiana, ele está longe de ser subsumido pura e simplesmente a um prazer sensorial, subsunção esta que o termo uoluptas, utilizado na obra, poderia sugerir. Para compreendermos o seu significado, não basta apenas ter em conta que os utopianos "consideram que a

\footnotetext{
240 "De uirtute disserunt, ac uoluptate, sed omnium prima est ac princeps controuersia, quanam in re una pluribusue sitam hominis felicitatem putent. At hac in re propensiores aequo uidentur in factionem uoluptatis assertricem, ut qua uel totam, uel potissima felicitatis humanae partem definiant." Cf. Utopia, 1993, pg. 161; Vtopia, 2015, pg. 329, tradução modificada. Como se sabe, uoluptas tradicionalmente se refere especificamente ao prazer dos sentidos.
} 
felicidade não se situa num prazer qualquer, mas apenas no prazer bom e honesto" ${ }^{241}$, ou que é para "esta felicidade, como sumo bem, que a nossa natureza é conduzida pela virtude",242 e que a virtude por sua vez é conduzida pela natureza: “[é] verdade que eles definem a virtude como sendo viver segundo a natureza, que o mesmo é dizer que para isso nós fomos ordenados por Deus." ${ }^{243}$ O sentido da moral utopiana começa a se delinear melhor no seguinte trecho:

Ora, deixa-se conduzir pela natureza todo aquele que no desejar ou no repudiar as coisas obedece à razão. A razão, por seu lado, antes de mais e em primeiro lugar, inflama (incendere) os homens ao amor e à veneração da divina majestade, a quem nós devemos tanto aquilo que somos como a nossa aptidão para a felicidade; em segundo lugar, ela convida-nos e impulsiona-nos a levarmos uma vida com o mínimo de ansiedade (minime anxiam) e com o máximo de satisfação (maxime laetam), e, por afinidade de natureza (naturae societate) a prestarmos assistência aos outros todos para alcançarem o mesmo; nunca, efectivamente, terá havido seguidor tão severo (tristis) e tão estrito (rigidus) da virtude e inimigo do prazer (uoluptatis) que aponte aos outros trabalhos, vigílias e austeridades, sem ao mesmo tempo ordenar que se dediquem a aliviar a pobreza e os sofrimentos dos outros; ele mandará proceder com força varonil e pensará mesmo que, em nome da humanidade, merece louvor o facto de alguém prestar ajuda e consolação a outro, sobretudo (já que nenhuma outra virtude é mais própria do homem) quando se trata de mitigar o sofrimento e aliviar a tristeza, devolvendo a alguém a alegria (iucundiatati), ou seja, a satisfação (uoluptati) de viver ${ }^{244}$.

Comecemos nossa análise pela primeira frase: “deixa-se conduzir pela natureza todo aquele que no desejar ou no repudiar as coisas obedece à razão". Num registro mais imediato ela parece entrar em contradição com a felicidade entendida como uoluptas. Parece no mínimo haver alguma desconformidade aqui. Se a nossa natureza é

\footnotetext{
241 "Nunc vero non in omni voluptate felicitatem, sed in bona, atque honesta sitam putant" Cf. Utopia, 1993, pg. 162; cf. também Vtopia, 2015, pg. 331.

${ }^{242}$ Cf. Utopia, 1993, pg. 86; cf. também Vtopia, 2015, pg. 267, grifo meu.

${ }^{243}$ Cf. Utopia, 1993, pg. 86; cf. também Vtopia, 2015, pg. 267.

${ }^{244}$ Neste trecho final ("sobretudo (já que nenhuma outra virtude é mais própria do homem) quando se trata de mitigar o sofrimento e aliviar a tristeza, devolvendo a alguém a alegria, ou seja, a satisfação de viver" - grifo meu) algumas opções do tradutor português parecem produzir um certo afastamento do original ("si humanum est maxime (qua virtute nulla est homoni magis propria) aliorum mitigare molestiam, \& sublata tristitia vitae iucunditati, hoc est uoluptati reddere" - grifo meu) Cf. Utopia, 1993, pg. 162 ; cf. também Vtopia, 2015, pgs. 331-332.
} 
conduzida para felicidade entendida como uoluptas, como, ao mesmo tempo, ela poderia nos levar a obedecer à razão? Mas na frase seguinte, entretanto, descobrimos que o que a razão faz em primeiro lugar é incendiar: "inflama os homens ao amor da majestade divina", que é a quem "devemos nossa aptidão para a felicidade", ou seja, para a uoluptas. Portanto, para esta moral peculiar, a uoluptas (ou a aptidão para ela) vem de Deus - “o ordenador da natureza”. Se voltarmos algumas páginas descobrimos ainda que a discussão da felicidade está ligada à religião:

Coisa mais de admirar é que procuram o patrocínio da religião para esta doutrina tão delicada (muito embora essa religião seja grave e severa, senão até um pouco triste e rígida). Nunca eles discutem sobre o problema da felicidade sem tirarem alguns princípios da religião e sem os associarem com a filosofia que se serve do raciocínio, pois sem os primeiros consideram que a razão só por si é falha e sem forças para indagar a verdadeira felicidade. Os princípios são do tipo seguinte: a alma é imortal e por benevolência de Deus foi feita para a felicidade; depois desta vida, à virtude e às boas ações estão destinados prêmios, aos crimes estão destinados castigos. ${ }^{245}$

Como, porém, entender que a religião que dá suporte a estes princípios possa ser "grave e severa, senão até um pouco triste e rígida"? De que modo uma religião grave e severa, um pouco triste e rígida poderia defender o prazer dos sentidos como efetiva finalidade humana?

Até aqui parece se confirmar a interpretação do padre Edward Surtz de que "na Utopia, a defesa da proposição de que o 'todo ou a principal parte da felicidade do homem' reside no prazer é essencialmente uma declamatio" nos termos definidos por Erasmo, ou seja, "uma composição escrita para a diversão e o prazer, tendo em vista o exercício do talento de alguém"246. Como um mero exercício literário, o que importa não é a verdade da questão, já que o autor pode exercitar seus talentos defendendo

${ }^{245}$ Utopia, pg. 160; Vtopia, pgs. 330

${ }^{246}$ Surtz, E. The defense of pleasure in More's Utopia, pg. 99 
temas indefensáveis, como a tirania ou a loucura, ou vilipendiar a virtude. Se se trata de uma declamatio, de saída, diz Surtz, a sua credibilidade é posta entre aspas (embora isso não impedisse que ela eventualmente pudesse vir a ser utilizada por motivos mais sérios). Talvez não fosse exagero afirmar que esta liberdade facilitaria a abordagem de determinados assuntos, "podendo mesmo ser um instrumento extremamente efetivo para o propósito de inovações impopulares e uma arma extremamente perigosa em um ataque à ordem estabelecida"247.

No caso de More, Surtz sustenta que o seu propósito não seria ventilar nenhuma idéia perigosa, mas tão somente "incitar e provocar" a reflexão dos cristãos "que estavam se comportando como se a riqueza ou a glória, não Deus, fossem o fim da vida" 248 . Tal como Erasmo havia feito anteriormente com a loucura (incluindo em seu âmbito até mesmo a cristandade), ao utilizar mais livremente a palavra uoluptas, More abarcaria uma ampla gama de prazeres do corpo e da alma ${ }^{249}$, causando irritação nos teólogos e filósofos ciosos das distinções e da precisão terminológica, obrigando-os a reconsiderar o sentido a cada vez ${ }^{250}$. A única que escaparia do embaralhamento provocado por More seria a felicidade eterna entendida como gaudium $^{251}$. Na interpretação de Surtz, esta seria a única felicidade verdadeira para os utopianos, os quais em suas orações rogam para que

Deus receba junto de si quem morre tranquilamente, tão depressa quanto possível ou tão tarde quanto cada um não ousaria definir. No entanto, seja dito sem ofender a sua majestade, ao coração apraz muito mais chegar a Deus depois de passar por uma morte

\footnotetext{
${ }^{247}$ Surtz, E. The defense of pleasure in More's Utopia, pg. 100

${ }^{248}$ Surtz, The defense of pleasure in More's Utopia, pg. 112

249 Lembremos que, como aponta Surtz, More inclui no campo semântico deste termo os sentidos de júbilo (iucunditas), alegria (laetitia), doçura (suavitas), deleite (delectatio) e até interesse (commoda). Cf. Surtz, The defense of pleasure in More's Utopia, p. 103.

${ }^{250}$ Surtz, The defense of pleasure in More's Utopia, pg. 103.

251 "Gaudium, however, is the consecrated scholastic term for the happiness of the beatific vision" cf. Surtz, The defense of pleasure in More's Utopia, pg. 107.
} 
cheia de dificuldades do que ficar por muito tempo separado d'Ele em grande prosperidade no decurso de uma vida. ${ }^{252}$

Ao expressar uma hierarquia de valores, segundo a qual a beatitude eterna tem precedência sobre vida terrena e seus prazeres - o que pressupõe, além da existência de Deus, a imortalidade da alma - os utopianos revelam que o seu verdadeiro "objeto de felicidade é a presença de Deus na próxima vida"253. Deste modo, não haveria nenhuma incompatibilidade entre a valorização do prazer, por um lado, e uma religião "grave", "severa", "triste" e "rígida", por outro.

Embora a aproximação da defesa do prazer na Utopia com Elogio da Loucura seja bastante persuasiva, talvez esta declamatio cumpra uma outra função no interior da obra, mais consubstancial à república utopiana. A hipótese é que a filosofia moral não é apenas um acréscimo exortativo, mas é coerente com a estrutura do constructo político. Não se trata aqui de negar a sua força crítica, muito pelo contrário, trata-se antes de mostrar que ela toma outra direção ${ }^{254}$.

Prosseguindo na análise do papel da razão na filosofia moral utopiana, se em primeiro lugar ela inflama os homens ao amor e à veneração de Deus, em segundo lugar ela impulsiona a "uma vida com o mínimo de ansiedade (anxiam) e com o máximo de satisfação (laetam) e por afinidade de natureza a prestarmos assistência aos outros para alcançarem o mesmo" ${ }^{255}$. Esta formulação lembra de perto o mandamento cristão expresso no evangelho, segundo o qual o próprio Cristo determina a amar a Deus sobre

\footnotetext{
${ }^{252}$ Utopia, pg. 236; Vtopia, 409.

${ }^{253}$ Surtz, E. The defense of pleasure in More's Utopia, pg. 112.

${ }^{254}$ Também não se trata de negar a presença do cristianismo na obra. De fato, Hitlodeu é um humanista cristão e, embora os utopianos não sejam cristãos, muitos princípios da filosofia moral e da religião utopiano lembram de perto os do cristianismo.

${ }^{255}$ Utopia, pg.162; Vtopia, pgs. 331-332.
} 
todas as coisas e ao próximo como a ti mesmo ${ }^{256}$. Aqui, na composição do discurso, já ocorre uma aproximação com a moral cristã. Sem que se perceba, a descrição da filosofia moral utopiana cativa e desperta certa simpatia, porque nela ressoam valores normalmente aceitos, o que compensa a desconfiança provocada pela afirmação um tanto chocante nos parágrafos anteriores de que a uoluptas seria a "maior parte ou a parte mais importante da felicidade". Segue-se a isso a parte mais delicada do discurso: "nunca efectivamente terá havido seguidor tão severo (tristis) e tão estrito (rigidus) da virtude e inimigo do prazer (uoluptatis) que aponte aos outros trabalhos, vigílias e austeridades, sem ao mesmo tempo, ordenar que se dediquem a aliviar a pobreza e os sofrimentos dos outros". Nesta verdadeira costura fina, somos convidados a encontrar no interior da máxima rigidez e severidade o imperativo ao alívio do sofrimento do outro. Trata-se de um chamado para um exame, um voltar-se para a própria experiência. Enquanto ainda mantém a oposição da severidade à uoluptas, aproxima ambos do alívio do sofrimento e da pobreza. Então o discurso prossegue:

ele mandará proceder com força varonil e pensará mesmo que, em nome da humanidade, merece louvor o facto de alguém prestar ajuda e consolação a outro - se é especialmente (maxime) humano (porque nenhuma outra virtude é mais própria ao homem) mitigar o sofrimento de outros e aliviar a tristeza, devolvendo a alguém a alegria de viver (uitae iucunditati), ou seja, o prazer (uoluptati) ${ }^{257}$.

Então são identificados com o humano e com a virtude que lhe é própria (a humanidade) o alívio da tristeza e a alegria de viver. Percebe-se que os termos não são utilizados ao acaso: o seguidor severo (tristis) e estrito (rigidus) da virtude (cujos qualificativos reverberam os da religião, também triste e rígida) recomenda e louva o alívio da tristeza, o que é o mesmo que reconhecer, ainda que sem o saber, a

\footnotetext{
${ }^{256}$ Mateus 22: 34-40.

${ }^{257}$ Cf. Utopia, pg 162; Vtopia, pgs. 331-332.
} 
necessidade da alegria de viver e do prazer. Assim, pois, se as virtudes serão recompensadas na vida após a morte, então, a humanidade, virtude maximamente humana e digna de louvor não o seria?

De passagem, vale notar: quem afinal proferiu este discurso? Na estrutura da obra, todo o relato da viagem à Utopia foi narrado por Hitlodeu. Entretanto, o que ele nos narra não é a sua própria filosofia moral, mas a dos utopianos. Ocorre que, pelo modo como este trecho em especial é apresentado (“ora, deixa-se conduzir pela natureza aquele que..."), o narrador acaba se confundido com a coisa narrada e passa de narrador a orador. Há ainda um outro processo de identificação. Não é somente Hitlodeu quem nos narra diretamente, mas o faz através do personagem More, que é o narrador. Mas este último, por sua vez, confunde-se obscuramente com o More autor da obra. Assim, as vozes dos utopianos, de Hitlodeu e dos dois More se sobrepõem e se mesclam.

Podemos perceber agora que esta filosofia, cuja principal virtude consiste em devolver a iucunditas e uoluptas para os outros, pelo alívio do sofrimento e da tristeza, está em consonância não somente com a natureza, mas com a estrutura social, funcionando como justificação moral do fundamento da organização política, ou seja, do comunismo utopiano. Pois, não é disso que se trata a utopia? Não é do alívio, na prática, da pobreza e da miséria? Não implica ela em iucunditas e uoluptas? Não está de acordo com o segundo mandamento da razão mencionado por Hitlodeu, que nos inclina a viver com o mínimo de ansiedade?

Assim, ao seguir as exigências próprias de uma filosofia moral, alicerçada nos princípios de uma "religião severa, grave, rígida e até mesmo triste", e, afim com ela, encontramos em seu âmago o prazer; mas também, neste mesmo movimento, na voz de Hitlodeu (e também dos utopianos e de More persona e narrador) nos deparamos com a 
figura do outro. É então, com esta pluralidade de vozes (a qual se junta o mais rígido seguidor da religião) que se diz que por afinidade de natureza (naturae societas) deve-se prestar ajuda ao outro, mitigar seu sofrimento e aliviar a tristeza. Portanto, a ideia de comunidade política que se delineia na figura do outro aparece no discurso associada à ideia de prazer, de forma que, a filosofia moral já remete à filosofia política.

Antes de reatarmos com Platão, resta ainda examinarmos como os utopianos definem o prazer (uoluptas) e de que forma ele se vincula à felicidade como uma finalidade política. No desenvolvimento da discussão sobre filosofia moral Hitlodeu afirma que os utopianos “designam por prazer (uoluptatem) todo o movimento ou todo o estado de corpo ou de alma nos quais o homem, guiado pela natureza, se delicia em viver". ${ }^{258} \mathrm{O}$ prazer a que se referem os utopianos é um prazer, por assim dizer, natural, mas para divisar mais claramente o que vem a ser esta espécie de volúpia natural é preciso acompanhar o caminho do discurso.

Não é sem razão que acrescentam "apetência natural". Efetivamente, como tudo o que é agradável (iucundum) por natureza, e para o qual tendemos (sem causar injustiças, sem perder um prazer maior, sem provocar um excesso de trabalho) é o que busca não apenas qualquer dos sentidos, mas também a recta razão, assim também os mortais, em exercício de fantasia (como se estivesse nas suas mãos poder transformar a realidade como mudam de palavra), imaginam prazeres que são contrários a natureza. ${ }^{259}$

Num primeiro momento, é possível compreender que o que se considera natural é definido pelo que é agradável por natureza aos sentidos e à reta razão, mas também em contraste com aquelas fantasias imaginadas pelos mortais. É por isso, que o discurso se desenvolverá descrevendo e discutindo justamente aqueles prazeres contrários à natureza, como aqueles advindos da valorização do ouro, de certas espécies de

\footnotetext{
258،Voluptatem appellant omnem corporis animiue motum statum que, quo uersari natura duce delectet." (grifo meu) Utopia, pg. 166; Vtopia, pg. 334.

${ }^{259}$ Utopia, pg. 166; Vtopia, pg. 334 (tradução modificada).
} 
honrarias, da caça e dos jogos. E são contrários à natureza porque são meramente imaginários, descolados das coisas mesmas. É o que ocorre, por exemplo, com a valorização da lã mais fina e não da mais grossa, já que a lã mais fina, por este atributo considerado em si mesmo, não oferece motivo suficiente para a sua valorização. É por isso que os utopianos se surpreendem "que alguém seja tão insano que julgue o grau de nobreza pela delicadeza do fio de lã, quando a verdade é que esta (por mais delicado que seja seu fio) andou antes no corpo da ovelha e não foi (...) outra coisa senão parte da ovelha. ${ }^{260}$ No entanto, valoriza-se ainda assim e se extrai prazer desta valorização, mas o motivo parece estar em outro lugar:

\begin{abstract}
Neste gênero de prazeres adulterados, colocam eles os que já anteriormente recordei: todos aqueles que quanto melhor toga têm tanto melhores se consideram. Numa coisa dessas o erro é duplo: efectivamente não estão menos enganados por avaliarem a sua toga acima do que vale como também por ela avaliarem a si mesmos. Realmente, se tivermos em vista a roupa que vestem, porque é que a lã de fio mais fino havia de ser superior à mais grossa? Ora, como se fosse por natureza e não por erro que dão nas vistas, estes homens pavoneiam-se todos e acreditam que daí lhes vem um valor não pequeno e por isso, como se fosse de direito próprio, por uma toga mais elegante reclamam uma honra, que não ousariam esperar se vestissem mais modestamente e ficam indignados quando se passa ao pé deles sem lhes prestar atenção especial ${ }^{261}$.
\end{abstract}

Não há como não reconhecer aqui os embaixadores anemólios da Elegantissima Fábula, como More ironicamente nomeou um dos poucos acontecimentos narrados na obra. Trata-se de um prazer obtido a partir de uma autovalorização indevida, a partir um aparato externo, que em si mesmo não possui este valor e não pode, portanto, transferilo a ninguém. Indicativo de que se trata de erro, não de um prazer natural ao qual se inclina a reta razão, é que, na ausência deste aparato externo, também desaparece a

\footnotetext{
${ }^{260}$ Utopia, pg. 156; Vtopia, pg. 326.

${ }^{261}$ Utopia, pg. 166; Vtopia, pg. 335.
} 
honra reclamada e com ela o prazer. Ao que parece, compartilha da mesma espécie de erro a valorização das reverências e da nobreza:

Ora, não será também prova de insipiência igual fixar-se em honrarias inúteis que nada aproveitam? De facto, que prazer autêntico e verdadeiro aduz alguém que venha de cabeça descoberta ou curve os joelhos? Será que isso contribui para curar a dor de joelhos de alguém, ou será que serve para aliviar uma dor de cabeça? ? $^{26}$

Hitlodeu descreve vários tipos de falsos prazeres advindos destas vãs fantasias ou loucuras (desde as mais leves até as positivamente detestáveis) em termos que muito se aproximam do Elogio da Loucura. Assim, são considerados insanos os adoradores de pedrinhas e de gemas que são incapazes de distinguir as verdadeiras das falsas, ou o caso daquele avarento que experimenta uma enorme alegria por ter enterrado um tesouro que acredita seguro e, por conta disso, vive dez anos contente, sem se dar conta que foi furtado ${ }^{263}$. Teria feito qualquer diferença se o dinheiro tivesse sido furtado ou permanecido a salvo? - pergunta More. A referência à comédia de Plauto serve para mostrar o quão vicioso é o prazer daqueles, “que acumulam riquezas supérfluas, não para se servirem do que acumulam, mas só para se deleitarem na contemplação" 264 . O ouro e também a prata assim tão tolamente considerados se afastam do valor que a própria natureza lhes atribui.

\footnotetext{
Aliás, quem não vê que estão abaixo do ferro, sem o qual os mortais (santo Deus!) não conseguem viver da mesma maneira que não podem passar sem o fogo e sem a água, ao passo que ao ouro e à prata nenhuma utilidade lhes foi atribuída pela natureza, pelo que facilmente passaríamos sem eles se não fosse a estultice dos homens em estabelecer um valor ao que é raro. Bem pelo contrário, a natureza, que é a mãe mais indulgente, colocou ao nosso alcance tudo o que ela tem de melhor, como é o ar, a água, a própria

${ }^{262}$ Utopia, pg. 166; Vtopia, pg. 335.

${ }^{263} \mathrm{O}$ exemplo em questão tem claramente como fonte o personagem principal da comédia $O$ Avarento de Plauto, embora More não remeta claramente à peça. Ocorre, entretanto, que se tratava de uma referência bem conhecida pelos membros de seu círculo humanista.

${ }^{264}$ Utopia, pg. 168; Vtopia, pg. 336.
} 
terra, mas colocou o mais longe possível tudo o que só serve à vaidade e nenhum proveito aduz. ${ }^{265}$

Da mesma forma que a reta razão, tendo a natureza por guia, determina os prazeres bons e honestos, as vãs fantasias (ou loucuras) fazem com que o espírito se ocupe inteiramente com a busca de falsos deleites como se fossem o sumo bem. Esta substituição dos prazeres naturais pelos falsos, não é sem consequência, pois estas falsas impressões de prazer não somente provocam desgostos e amarguras, mas também constituem um obstáculo à felicidade, como, por exemplo, o orgulho mencionado na peroração, mas também a usura que troca o brilho das estrelas pelo reluzir de pequenas pedrinhas e o prazer inclemente da caça ${ }^{266}$ :

não haverá mais incômodo que alívio ter que ouvir os cães a ladrar e até a uivar? Ou haverá maior sensação de prazer quando um cão persegue uma lebre do que quando corre atrás de outro cão? Na realidade, trata-se da mesma coisa, se é que é o correr que desencadeia o prazer! Pelo contrário, se é a espera do sangue e a expectativa da dentada que retêm suspenso o olhar, deve mover sobretudo à compaixão observar que um lebracho é desfeito por um cão, um fraco por outro mais forte, enfim, um ser inofensivo por outro que é cruel. ${ }^{267}$

Como estes falsos prazeres não são nada naturais ou racionais (pois a natureza, de acordo com o ordenamento estabelecido pela majestade divina, indica à reta razão outra direção), mas devem sua origem aos hábitos e aos costumes instituídos pelos homens, podem então ser modificados ${ }^{268}$.

\footnotetext{
${ }^{265}$ Utopia, pg. 150; Vtopia, pg. 321.

266 "Pythagoras, Lucretius, Ovid, Seneca, and Plutarch all gave vivid narratives designed to explain war's rise in the world. The commonplaces of this classic social criticism are worth summing up. The Golden Age peace was broken, it was poetically surmised, when men first began to kill animals. Degenerating progressively, men became accustomed to brutality, until they actually learned to enjoy butchery. Eventually even manslaughter and war became habitual and finally were termed glorious. Admiration and applause came to be showered upon bloody conquerors like Alexander the Great, who would once have been regarded as insane homicides." Cf. Adams, Robert. The better part of valor, pg. 6 .

${ }^{267}$ Utopia, pg. 170 ; Vtopia, pg. 337.

${ }^{268}$ Utopia, pg. 172; Vtopia, pg. 338.
} 
Por isso, os utopienses repudiam esta prática da caça, como coisa indigna para homens livres, remetendo-a para carniceiros (ofício que entregaram, como dissemos, nas mãos de servos ${ }^{269}$ ). De facto, consideram que a caça é a parte mais degradada desse ofício de talhante, quando comparada com outras acções mais úteis e mais honrosas que são de muito maior proveito; aliás, os talhantes não matam os animais senão por necessidade, ao passo que o caçador mata e destroça um animalito só por um pouco de prazer. Consideram eles que é indigno o anseio de assistir à matança dos animais e que ou brota de uma sensibilidade que roça pela crueldade ou procede de prática insofrida de prazer tão desenfreado que acaba em crueldade ${ }^{270}$.

O discurso ensina pelo exemplo, pois é pela imagem por ele fornecida e não por uma demonstração abstrata, que se vislumbra o que vem a ser estes falsos prazeres, desagradáveis no fim, bem como os motivos pelos quais eles se afastam da natureza. A sequência acaba por servir como preparação para que o narrador, enfim, possa apresentar quais seriam afinal estes prazeres naturais, com que o corpo e a alma verdadeiramente se deleitam.

Nos prazeres que reconhecem como autênticos, os utopianos assinalam diversas espécies: uns atribuem-nos à alma, outros ao corpo. À alma associam o entendimento e o gozo que a contemplação da verdade faz nascer; a isso junta-se a recordação agradável de uma vida bem passada e a esperança sem vacilação de um bem futuro. Quanto ao prazer do corpo repartem-no em dois tipos. O primeiro deles será aquele que inunda os sentidos de uma acalmia de plenitude - que, aliás, faz parte da restauração das forças que a combustão interna dos órgãos vai fazendo esmorecer; tal restauração é conseguida pela digestão da comida e da bebida, ao mesmo tempo, aliás, que se vai purgando o excedente que o corpo não necessita - função que ocorre seja quando aliviamos os intestinos dos excrementos seja no acto de procriação, seja também quando apaziguamos o prurido de uma parte do corpo, coçando ou friccionando. Por vezes, porém, o prazer surge sem que o corpo receba seja o que for daquilo que os seus membros gostariam ou sem que lhe desapareça o que lhes causa incômodo: trata-se de um prazer que, por uma espécie de força oculta, mas perceptível, faz vibrar e afaga os nossos sentidos e os cativa, como é o que brota da música. Quanto ao segundo tipo de prazeres físicos, querem eles que sejam os que consistem em estado de quietação sem perturbações somáticas, isto é, em gozar de saúde sem ter entraves de doenças; na realidade, se não houver que enfrentar a dor, o bem-estar é já de si uma satisfação, mesmo que a vida decorra sem ocasionar um prazer vindo de fora. ${ }^{271}$

\footnotetext{
${ }^{269}$ No original, seruuos, que, na utopia, são aqueles indivíduos condenados por crimes.

${ }^{270}$ Utopia, pg. 170; Vtopia, pg. 337.

${ }^{271}$ Utopia, pg. 172; Vtopia, pg. 338-339.
} 
No fim das contas, o que os utopianos entendem por uoluptas, no que respeita à alma, é a contemplação da verdade (que inclui entendimento e gozo) e uma vida ativa virtuosa (que envolve a memória dos feitos passados e a esperança na recompensa futura $)^{272}$. No caso do corpo, o que está sendo chamado de uoluptas nada mais é do que a satisfação das necessidades fisiológicas (aí compreendidos movimento e plenitude) e na saúde em si mesma, que provê uma quietude proveniente da ausência de dor e de perturbação. A uoluptas, como prazer natural, está associada ao movimento e ao repouso da alma (entendimento/gozo da verdade; ação virtuosa/ memória e esperança) e do corpo (necessidade/ satisfação; perturbação/quietude).

Se, por um lado, o prazer corporal considerado natural se restringe à sustentação do corpo em si, por outro lado, o prazer mais completo, o máximo da uoluptas é a saúde, entendida como um estado de tranquilidade do corpo, que é em si mesma aprazível e deleitosa. De modo que os pares anteriormente apresentados não são equivalentes. Pelo contrário, a quietude e a satisfação não somente têm precedência sobre o movimento, como lhe dão sentido. Ora, perguntam os utopianos, "enquanto comemos, o que acontece senão que a saúde, que começara a declinar, fazendo aliança com o alimento, entra em luta contra a fome que se faz sentir? À medida que a saúde ganha forças, regressa-se ao vigor costumado e este faz surgir o prazer que é o que experimentamos quando tomamos o alimento."273 Por este motivo, os utopianos sustentam que, "dos prazeres do corpo cabe a palma à saúde, pois [eles] têm bem presente que a satisfação de comer e de beber e tudo aquilo que corresponde a um plano

\footnotetext{
${ }^{272}$ Rep. 331a "quem tem consciência de que não cometeu nenhuma injustiça, tem a seu lado a doce esperança, a boa nutriz da velhice, como diz Pindaro."

${ }^{273}$ Utopia, pg. 174; Vtopia, pg. 340
} 
de gozo da vida deve ser posto como finalidade mas em razão da saúde"274. Pois, se assim não fosse, "o cúmulo da felicidade deveria, em última instância, colocar-se num gênero de vida em que esta consistisse em andar permanentemente com fome, sede, prurido, para haver como contrapartida comer, beber, coçar-se... Mas quem não veria que isso seria não só ignóbil, mas também digno de dó?"275 $\mathrm{Na}$ verdade, a saúde não somente é finalidade, mas é condição mesma dos demais prazeres, "pois sem ela não há lugar em parte alguma para qualquer tipo de prazer" ${ }^{276}$.

Se, por um lado, a saúde (entendida como plenitude do deleite e ao mesmo tempo condição e finalidade dos prazeres do corpo) é o máximo de prazer que o corpo pode atingir; por outro, os prazeres não se esgotam no corpo, já que os prazeres da alma são superiores. Mas se, em simetria com o que ocorre com os prazeres do corpo, poderíamos supor que o gozo da verdade seria superior à busca de conhecimento e que a vida contemplativa seria superior à ativa, a filosofia moral utopiana surpreende ao estabelecer que os prazeres do espírito "derivam sobretudo do exercício da virtude e da consciência de uma vida de bem" ${ }^{277}$. Não é à toa que é o exercício da virtude e não a contemplação da verdade que está no topo dos prazeres do espírito, pois, como bem notou Surtz, a plenitude, em última instância, está em outro lugar, ou seja, nas recompensas recebidas pela alma imortal. A partir daí é possível compreender de que forma esta filosofia moral obtém seu complemento dos princípios religiosos

\footnotetext{
274 "Earum uoluptatum quas corpus suggerit, palmam sanitati deferunt. Nam edendi, bibendique suauitatem, et quicquid eandem oblectamenti rationem habet, appetenda quidem, sed non nisi sanitatis gratia statuunt." Cf. Utopia, pg. 176; Vtopia, pg. 34.

${ }_{275}^{275}$ Utopia, pg. 176; Vtopia, pg. 341

276 "Quamquam enim sese minus effert, minusque offert sensui, quam túmida illa edendi bibendique libido, nihilo tamen secius multi eam statuunt uoluptatum maximam, omnes fere Vtopienses magmam et uelut fundamentum omnium ac basim fatentur, ut quae uel sola placidam et optabilem uitae conditionem reddat, et qua sublata, nullus usquam reliquus sit cuiquam uoluptati locus". Utopia, pg. 174; Vtopia, pg. 339. Também na República a saúde é posto entre os bens que são buscados "por eles mesmos e pelo que deles decorrem". Cf. Rep. 357c

277 "Amplectuntur ergo in primis animi uoluptates, - eas enim primas omnium principesque ducunt quarum potissimam partem censent ab exercitio uirtutum bonaeque uitae conscientia proficisci". Cf. Utopia, pg. 176; Vtopia, pg. 341.
} 
anteriormente mencionados. "Os princípios são do tipo seguinte: a alma é imortal e por benevolência de Deus foi feita para a felicidade; pois desta vida, à virtude e às boas acções estão destinados prêmios, aos crimes estão destinados castigos." ${ }^{278}$ Mas, note-se que estes princípios dizem respeito à verdadeira felicidade:

Nunca eles discutem sobre o problema da felicidade sem tirarem alguns princípios da religião e sem os associarem com a filosofia que se serve do raciocínio, pois sem os primeiros consideram que a razão por si só é falha e sem forças para indagar a verdadeira felicidade ${ }^{279}$.

Mas não é exatamente para usufruir mais imediatamente desta verdadeira felicidade que os utopianos são liberados das servidões do corpo, mas para cultivarem livremente o espírito (animem libertatem cultum) ${ }^{280}$, sede dos prazeres superiores, em que, de pleno direito, se situa a felicidade da vida.

De fato, mesmo que não haja muitos que sejam dispensados do trabalho físico para se dedicarem apenas à reflexão (como são os que desde os primeiros anos de vida são reconhecidos como sendo dotados de nobreza de caráter e de inteligência superior além de terem inclinação para as artes liberais), mesmo assim todas as crianças são iniciadas nas letras, e uma larga percentagem da população, homens e mulheres, ao longo de toda a vida, nas horas que, como dissemos, ficam isentas de trabalho manual, dedicam-se às letras. ${ }^{281}$

A partir deste percurso é possível agora reatarmos com Platão, uma vez que se verifica que a incompatibilidade é apenas aparente, pois os utopianos não defendem um prazer, por assim dizer, tirânico. É possível perceber, inclusive, que esta valorização do

\footnotetext{
${ }^{278}$ Utopia, pgs. 160-162; Vtopia, pg. 330.

${ }^{279}$ Utopia, pgs. 160-162; Vtopia, pg. 330. (grifo meu)

${ }^{280}$ Utopia, pg. 134; Vtopia, pg. 309.

${ }^{281}$ Utopia, pg. 158; Vtopia, pg. 327. Este aspecto é tão importante que é mencionado pelo menos três vezes no livro: "A maior parte consagra às letras estas horas de folga. De facto, é de regra haver cada dia lições públicas nas primeiras horas do dia, sendo obrigatório que a elas assistam aqueles que foram expressamente seleccionados para as letras; além disso, um grande número de homens e de mulheres de todas as condições desloca-se para escutar estas lições, uns umas, outros outras, segundo a inclinação natural de cada um." Utopia, pg. 128; Vtopia, pg. 303-304.
} 
cultivo do espírito (visto como uma forma superior de uoluptas), na maneira como se enquadra nas instituições religiosas e políticas da Utopia, se aproxima muito de certas concepções platônicas acerca dos verdadeiros guardiões e do processo de escolha dos mesmos. Afinal, a cidade ideal que nomeia o livro de More, as magistraturas são ocupadas exclusivamente pelos acadêmicos.

Efectivamente, ali, em toda a cidade e nos seus arrabaldes, mal haverá quinhentas pessoas de toda a população de homens e mulheres, que tenham idade e robustez para o trabalho manual, a quem seja consentido ficarem sem ocupação. Entre eles contam-se os sifograntos; todavia, embora a lei os isente de trabalho, eles próprios não se dispensam de o fazerem, com o objetivo de que, dando o exemplo, os outros se sintam impelidos a segui-lo. Da mesma isenção gozam aqueles aos quais, por recomendação dos sacerdotes, e por voto secreto dos sifograntos, o povo tenha reconhecido ser oportuno conceder dispensa sem limite de tempo para se dedicarem ao estudo da ciência.

Todavia, se alguém deixar frustradas as esperanças nele postas, será recambiado para o trabalho manual. Pelo contrário, não é raro que um trabalhador manual, durante as horas de descanso, se consagre às letras com tal diligência e obtenha tal aproveitamento que seja dispensado do seu mester para passar à classe dos letrados. Nesta classe são escolhidos os embaixadores, os sacerdotes, os traníboros, enfim, o próprio príncipe, a quem na sua língua primitiva davam o nome de barzanes e modernamente designam por ademo. ${ }^{282}$

Ainda que na República de Platão a comunidade de bens, mulheres e crianças

fique circunscrita especificamente aos guardiões, enquanto que na Utopia os bens (e somente eles) sejam compartilhados por todos, a prática adotada pelos utopianos não é de todo estranha a Platão. A ampliação da comunidade de bens a toda Cidade é mesmo proposta nas Leis, pelo Ateniense, personagem tido como porta-voz das concepções de Platão.

Em primeiro lugar, temos a cidade, a forma de governo e as leis ideais, confirmantes, com satisfatória aproximação, do antigo provérbio que nos mostra como tudo entre amigos é comum. Se tais condições se observam presentemente em qualquer parte, ou se algum dia chegarão a concretizar-se - serem em comum as mulheres, comuns os filhos, comuns todos os bens - no caso de ficar banida o que se chama propriedade particular, e se se conseguir, na medida do possível, tornar comum, de um jeito ou de

${ }^{282}$ Utopia, pgs. 130-132; Vtopia, pg. 306-307. 
outro, até mesmo o que por natureza é nosso, como os olhos, os ouvidos e as mãos, de forma que todos pareçam ver, ouvir ou trabalhar em comum, e que todos, a uma voz, dentro das possibilidades humanas, elogiem ou censurem as mesmas coisas, por se alegrarem ou entristecerem com elas, e havendo, em suma, conseguido as leis amoldar a cidade na mais perfeita unidade que se possa conceber: ninguém jamais adotará critério melhor e mais acertado do que esse, para atingir o mais alto grau da virtude. Numa cidade assim constituída, quer seja povoada por deuses, quer por filhos de deuses, em grande número seus habitantes viverão na maior alegria ${ }^{283}$.

Além disso, Platão não está entre os inimigos do prazer. Ocorre apenas que ele considera (como Céfalo e também como o Ateniense) que os "bens são excelentes para os homens justos e piedosos, e para os injustos, o pior dos males, a começar pela saúde.” ${ }^{284} \mathrm{Na}$ educação do cidadão virtuoso, afirma o Ateniense,

para que a criança não se habitue aos sentimentos de dor e de prazer contrários à lei e ao que a lei recomenda, mas se alegre ou se entristeça de acordo com os princípios válidos para os velhos, inventou-se o que se chama canto, que, em verdade, são encantamentos para a alma, destinados à produzir o acordo a que nos referimos" ${ }^{285}$.

Na Utopia este acordo também é buscado, como se verifica na associação do ouro com objetos considerados ignóbeis como urinóis e algemas. Mas, o fator determinante para operar a modificação que leva a ordenar o prazer de acordo com a natureza é a comunidade de bens, que reorganiza a Cidade em função do interesse público, o qual, ao mesmo tempo, é idêntico ao interesse de cada um.

A referência ao vínculo entre felicidade e interesse público abre espaço para que reconheçamos também na Utopia indicações de uma importante relação com outra obra

\footnotetext{
${ }^{283}$ Leis 739 c-e

${ }^{284}$ Leis 661 b-c; Rep. 329a -330a

${ }^{285}$ Leis, 659 d-e
} 
clássica que aborda, em várias passagens, a questão da cidade ideal, a saber, a Política de Aristóteles, à qual já nos referimos anteriormente. Com efeito, como apontamos antes, a concepção de um entrelaçamento entre felicidade e interesse público está presente tanto na República, quanto na Política e na Utopia. Na República este entrelaçamento tinha fortes conotações metafísicas e, em boa medida, era pensado como um ideal para o qual a possibilidade de realização efetiva constituía um aspecto secundário diante de seu papel de critério orientador. Na Política o aspecto metafísico está bem menos presente, enquanto que, por outro lado, Aristóteles preocupa-se com os meios que tornariam possível a constituição de uma pólis ideal. Como aponta Logan,

De acordo com Aristóteles, Platão errou na República ao não considerar "os ensinamentos da experiência efetiva" (Pol. II, 1264a). Mesmo ao se discutir uma pólis ideal não existente "não pode ser correto fazer qualquer pressuposição que seja claramente impossível" (1265a), já que para que o padrão de uma pólis ideal seja útil, as condições ideais "devem ser capazes de realização tanto quanto de serem ideais" (VII. $1325 b){ }^{286}$

A Utopia, por fim, ainda que não seja um programa de reformas práticas, descrevendo uma república ideal que funciona antes como um parâmetro crítico, apresenta esta república (como procuramos indicar no final do capítulo anterior) como sendo dotada do caráter de uma obra humana e, portanto, de uma relação com a viabilidade mais próxima das considerações de Aristóteles que das de Platão. O exame dos possíveis pontos de contato entre a obra de Aristóteles e a de More mostra-se, então, importante para uma correta caracterização desta última. As diferenças entre ambas colocam algumas dificuldades, uma vez que o texto de Aristóteles tem um caráter mais diretamente analítico e normativo, enquanto que o livro de More aborda as questões de

\footnotetext{
${ }^{286}$ Logan, The meaning of More's Utopia, pg. 132.
} 
maneira mais enviesada e ambígua, por meio do relato de Hitlodeu. É, porém, possível traçar algumas aproximações. ${ }^{287}$

Como um primeiro ponto de aproximação, o que aparece em ambas as obras é o estabelecimento das condições necessárias para a felicidade humana (eudaimonia). Estas condições são concebidas em termos ideais, ou seja, como o melhor arranjo possível para o cumprimento da finalidade que se tem em vista. No que respeita ao livro VII da Política, que é aquele dedicado à discussão da pólis ideal, Aristóteles examina em primeiro lugar (ainda que de maneira muito resumida, pois a questão pertence ao âmbito da ética) qual é a vida mais desejável. Para tanto, retoma a consideração platônica segundo a qual há três classes de bens, a saber, os externos, os do corpo e os da alma (estes últimos designados pelos termos excelência ou virtude) e aponta que “ninguém negaria que um homem feliz deveria ter os três". Há discordância no que diz respeito a quais bens são superiores, mas o simples exame dos fatos permite resolver a questão:

\begin{abstract}
Alguns pensam que uma moderada quantidade de excelência é o bastante, mas não estabelecem limites para seus desejos por riquezas, propriedade, poder, reputação e coisas semelhantes. A eles, nós devemos responder apelando aos fatos, os quais facilmente provam que a humanidade não adquire e preserva as excelências com a ajuda de bens exteriores, mas os bens exteriores com a ajuda das excelências ${ }^{288}$ e que a
\end{abstract}

\footnotetext{
287 Tal como George Logan em The meaning of More's Utopia, no que segue me apoio na discussão desenvolvida por Thomas White no artigo "Aristotle and Utopia". White chama a atenção para o fato de que boa parte dos comentadores ignora Aristóteles enquanto referência importante para a Utopia, limitando-se a apontar a relação com Platão. Os motivos para isso seriam tanto o caráter mais ostensivo das referências à República quanto o fato de que muitas vezes o antagonismo dos humanistas em relação à escolástica foi entendido como consistindo também em um anti-aristotelismo. Em contraposição, ele lista exemplos de citações de Aristóteles encontradas em diferentes obras de More, um elogio direto que se encontra na carta a Dorp e o fato de que Hitlodeu, ao sair em viagem, levara um conjunto de livros dentre os quais os de filosofia eram "a maior parte das obras de Platão, bastantes (pluria) de Aristóteles" e “a obra de Teofrasto sobre as plantas" (Utopia, pg. 180; Vtopia, pgs. 346-347). Em nossa discussão a seguir faremos referência não apenas à Política, mas também à Ética nicomaquéia, uma vez que muitos temas das duas obras estão fortemente interligados.

${ }^{288}$ Vale notar que este trecho se assemelha muito a uma passagem da Apologia na qual Sócrates diz: "Nenhuma outra coisa faço enquanto circulo a não ser persuadir, tanto os mais jovens quanto os mais velhos dentre vocês, a não militar em favor nem do corpo nem do dinheiro - não antes (nem com a
} 
felicidade, quer consista no prazer ou na excelência, ou ambos, é mais frequentemente encontrada naqueles que são mais altamente cultivados em sua mente e em seu caráter e tem apenas uma parcela moderada de bens exteriores, do que entre aqueles que possuem os bens exteriores numa extensão inútil, mas são deficientes nas mais altas qualidades. ${ }^{289}$

Desta forma fica claro que a vida mais desejável é aquela que atribui aos bens da alma a devida precedência diante dos bens do corpo e dos bens externos (pois a eudaimonia depende efetivamente da excelência), e Aristóteles pode então dizer que "cada um tem tanto de felicidade quanto tem de virtude e sabedoria, e de ação virtuosa e sábia”. Em seguida, nota que ninguém nega que a felicidade do indivíduo é a mesma da pólis, de modo que ambas consistem no exercício da virtude ${ }^{290}$. Vimos já que o exercício da virtude é uma parte do que os utopianos consideram ser a uoluptas (a outra parte sendo a contemplação da verdade), e nisto encontramos um ponto de aproximação não apenas entre a Utopia e a República, mas também em relação à Política.

Concluída esta discussão (que Aristóteles considera como apenas introdutória) e tendo-se determinado que a vida mais desejável (causa final) é a virtuosa, é preciso então identificar quais as condições políticas que a tornariam possível, o que Aristóteles fará a partir do capítulo 4. Como aponta White, o critério dirigente aqui é a noção de autossuficiência (autárkeia), "pois a pólis perfeita não pode existir sem o devido suprimento de meios de vida"291 ${ }^{\text {E }}$, neste sentido, Aristóteles volta-se primeiramente para a causa material:

Assim como o tecelão, ou o construtor de navios ou qualquer outro artesão deve ter o material apropriado para o seu trabalho (e numa proporção tal que esteja melhor

mesma intensidade) que em favor da alma, a fim de ser a melhor possível -, e vou dizendo que não surge do dinheiro a virtude, mas da virtude o dinheiro e todos os demais bens humanos, públicos e privados" (Apologia de Sócrates, 30).

${ }^{289}$ Pol. 1323a 25- 40; 1323b 1-5

${ }^{290}$ Os capítulos 2 e 3 do livro VII abrangem ainda vários outros tópicos, mas não é necessário abordá-los neste momento.

${ }^{291}$ Pol. 1325 b 35. 
preparado, de modo que o resultado de sua arte seja mais nobre), assim também o estadista ou legislador deve ter materiais adequados a ele. Em primeiro lugar entre os materiais exigidos para o estadista está a população; ele considerará qual deve ser o número e o caráter dos cidadãos, e então qual deve ser o tamanho e o caráter do território. $^{292}$

O número de cidadãos deve ser tal que não seja nem muito reduzido nem excessivamente grande, pois o Estado, assim como outras coisas, deve ter um limite de tamanho apropriado, ou correrá o risco de não poder alcançar sua finalidade. White sublinha que Aristóteles não indica aqui os meios para se alcançar o número apropriado, mas que

no livro II ele sugere que se os legisladores regularem a quantidade de propriedade por família, eles deveriam limitar também o tamanho da família (1266b 8-13). E depois no mesmo livro ele descreve a prática cartaginesa de se transferir periodicamente uma porção da população para cidades dependentes (1273b 19-20). ${ }^{293}$

Hitlodeu relata que os utopianos se preocupavam em regular o crescimento da população, embora o texto não desenvolva nenhuma discussão ou justificativa a respeito, limitando-se a a se referir ao temor de que as cidades ficassem com um número muito reduzido ou excessivo de habitantes:

Para que a cidade não perca habitantes ou para que não cresça desmedidamente, tomamse precauções para que nenhuma família (das seis mil que compõem cada cidade, sem incluir o seu aro) não tenha menos de dez nem mais de dezasseis púberes (quanto aos impúberes ninguém se permite definir o seu número). Tal quantitativo é mantido de forma habilidosa pois quando ele é ultrapassado em algumas famílias, os excedentes passam para as famílias deficitárias. Todavia, se alguma vez o total ultrapassa o previsto, compensam a falta de efectivos de outras das suas cidades. Mas se casualmente a população global crescer por toda a ilha mais que o estipulado, então, recrutam-se cidadãos de cada uma das cidades que vão fundar uma colónia com as suas

${ }^{292}$ Pol. 1325 b 40-1326a 5.

${ }^{293}$ WHITE, “Aristotle and Utopia”, pg. 643-644. 
mesmas leis em território vizinho onde a população tenha terras de cultivo em excesso sem as cultivar e onde os habitantes locais aceitem fazer aliança e viver lado a lado. ${ }^{294}$

White chama a atenção para o fato de que na Utopia, assim como antes na Política, as providências iniciais para se cuidar deste aspecto dizem respeito à quantidade de membros em cada grupo familiar, enquanto que o processo de transferência do excedente populacional para outras cidades ou terras lembra o costume dos cartagineses. Por outro lado, não deixa de haver diferenças: enquanto Aristóteles dizia que seria necessário limitar o número de filhos, recomendando no capítulo 16 que, "se casais tiverem filhos em excesso, sejam realizados abortos antes que os sentidos e a vida tenham se iniciado" 295 , o livro de More menciona outro processo pelo qual o controle era exercido no âmbito da família (a transferência de jovens e/ou adultos de um núcleo familiar para outro) e diz que não se limitava o número de crianças por casa. De qualquer forma, é possível notar em ambos os casos uma preocupação em se prevenir problemas que pudessem resultar de desequilíbrios quanto ao número de habitantes.

A questão abordada em seguida por Aristóteles refere-se ao território. Como se trata de descrever condições ideais, mas viáveis, ele procura traça-las de modo que, ainda que imaginárias, não sejam impossíveis ${ }^{296}$. Assim, o território preferível é aquele "que é o mais autossuficiente; e este deve ser o território que pode produzir tudo o que for necessário, pois ter todas as coisas não precisar de nada é suficiência"297. Além disso, sua extensão deve ser tal que permita "aos habitantes viver ao mesmo tempo de maneira temperante e livre, no gozo do ócio"298.

\footnotetext{
${ }^{294}$ Utopia, pgs. 134-136; Vtopia, pgs. 309-310.

${ }^{295}$ Pol. 1335b 24-25.

${ }^{296}$ Pol. 1325 b 38-39.

${ }^{297}$ Pol. $1326 \mathrm{~b} 27-30$.

${ }^{298}$ Pol. 1326b 30-31.
} 
Não deixa de ser curioso que a Utopia, lugar imaginário, não corresponda exatamente às condições ideais de Aristóteles. Embora não haja muitos detalhes a respeito, menciona-se de passagem que "seu solo não é uniformemente fértil nem o clima é dos mais salubres"299. Além disso, ainda que apenas por conta de um metal, não se poderia dizer que têm todas as coisas e não precisam de nada, pois falta-lhes ferro ${ }^{300}$, de modo que praticam o comércio com certa regularidade. Mas isto quer dizer que não seja autossuficientes? $\mathrm{Na}$ verdade, reencontramos aqui o caráter de obra humana que marca a Utopia e a dota de um tom particularmente moderno. Ocorre que, se não a generosidade do solo, a forma de organização do trabalho permite que, de maneira geral, se produza mais do que o suficiente, de modo que os períodos regulares de trabalho podem mesmo ser reduzidos. Não se depende tanto das condições naturais, mas age-se de maneira a procurar construir a própria autossuficiência por meio da atividade humana, isto é, os seres humanos possuem recursos que lhes permitem alcançar a autossuficiência. E mesmo aquilo que não pode ser produzido, como no caso do ferro, é obtido pelo comércio possibilitado pela fartura na produção de outros objetos.

A questão do comércio, por sua vez, abre espaço para o exame de outro aspecto que preocupa Aristóteles. Com efeito, ele considera que a cidade deveria estar bem situada tanto em relação ao mar quanto à terra. Ao mesmo tempo, porém, seu território deve ser de difícil acesso para os inimigos, mas acessível para o retorno dos habitantes, e deve ser apreensível inteiramente por um olhar, para assim facilitar a proteção. Ora, a proximidade com o mar comporta vários riscos, o primeiro dentre eles sendo os ataques de inimigos. Trata-se de um risco considerável, entre outros motivos porque a liberdade é um componente importante da autossuficiência. E embora a pólis não deva ser voltada

\footnotetext{
${ }^{299}$ Utopia, pg. 178; Vtopia, pg. 344.

${ }^{300}$ Utopia, pg. 148; Vtopia, pg. 319.
} 
para a guerra (pois que a guerra é em vista da paz, que lhe é superior, assim como o negócio é em vista do ócio), ela deve, entretanto, se valer de bons meios para proteger os seus cidadãos, "pois verdadeiramente, como o provérbio diz, "não há ócio para escravos' e aqueles que não podem enfrentar o perigo como homens, são escravos dos invasores" ${ }^{301}$. Por conta disso, Aristóteles recomenda a construção de muralhas e fortificações, e também que proximidade com o mar seja aproveitada para a criação de uma força naval moderada e o desenvolvimento de desejáveis habilidades marítimas de modo a se estar pronto para enfrentar conflitos não apenas na terra, mas também no oceano. Outro ponto importante com relação a este aspecto consiste no fornecimento de meios adicionais para a atividade comercial, por onde se obtém uma maior facilidade para a entrada das provisões necessárias. Entretanto, a pólis deve encontrar maneiras de afastar os inconvenientes dos portos, advindos do ir e vir de mercadores e de estrangeiros (os quais não apenas foram criados sob outras leis e costumes, como ainda colocam em risco o equilíbrio populacional) e do possível incentivo à busca por lucros.

É fácil ver que a Utopia atende bem à várias das exigências aristotélicas quanto a este ponto. Afinal, trata-se de uma ilha de duzentas milhas de largura ${ }^{302}$, em formato de lua crescente e de difícil acesso:

A ilha de Utopia tem de largura umas duzentas milhas na sua parte central (onde atinge
o máximo). Não é muito mais estreita ao longo do seu perímetro, mas para as
extremidades adelgaça progressivamente de ambos os lados; aquelas encurvam e
desenham um arco de círculo de quinhentas milhas de circunferência, dando à ilha, no
seu todo, um a configuração de uma lua em quarto crescente. As águas do mar correm
de lado a lado, por entre as pontas do crescente que distam uma da outra mais ou menos
umas onze milhas, espraiam-se por um imenso golfo, resguardadas dos ventos por terra
em todo o redor, remansosas e raramente agitadas, como se fossem um lago; formam

${ }^{301}$ Pol. 1334a 15-20.

${ }^{302}$ Nos comentários no final do volume 4 das Obras Completas de More, Surtz informa que: "Mil passos compunham uma milha romana (1620 jardas). A Utopia tem cinco mil milhas de extensão e duzentas milhas de largura e é portanto aproximadamente as dimensões da Grã-Bretanha como concebidas na época" (Utopia, pg. 384). 
um porto quase no seio daquela terra, e proporcionam grandes vantagens aos navios que os habitantes fazem circular para todas as partes. Há entradas que, seja pelos baixios, seja pelos escolhos, se tornam muito perigosas. Mais ou menos a meio da passagem fica um rochedo, mas, porque está à vista, por isso mesmo é inócuo; aí construíram uma torre e mantêm uma guarnição; os restantes estão escondidos e são traiçoeiros. (...) Os portos não são raros, mas por toda ilha o desembarque é por tal modo protegido por meios naturais ou por meios artificiais que até forças ingentes podem ser rechaçadas por poucos defensores ${ }^{303}$.

Além das defesas oferecidas por meios naturais e artificiais, White nota ainda que há uma breve referência à existência de uma força naval: "Se deflagar algum caso de guerra no seu território, mesmo os poltrões, desde que tenham corpo vigoroso, são misturados a outros melhores e colocam-nos nos navios ou espalhados pelas muralhas" 304 .

Quanto ao comércio, é importante destacar que a atividade comercial dos utopianos não é plenamente regular e não tem como finalidade o lucro. Depois de asseguradas reservas para um período de dois anos, a produção excedente é exportada para outras regiões, sendo um sétimo dos produtos dado para os necessitados e o resto vendido "com um lucro moderado" 305 . Como os utopianos têm pouco uso para dinheiro, ouro ou prata (exceto a fabricação de objetos como "os urinóis e os vasos mais sórdidos", "as correntes e os grosso grilhões com que prendem os escravos de castigo" e os brincos, anéis e colares que colocam nos criminosos "para declarar a sua infâmia"), os recursos obtidos são guardados para uso em situações excepcionais, como as guerras. Além disso, eles fogem aos riscos decorrentes do trânsito de comerciantes estrangeiros na medida em que evitam que a atividade comercial seja desenvolvida em seu território, pois consideram que

\footnotetext{
${ }^{303}$ Utopia, pg. 110; Vtopia, pg. 290.

${ }^{304}$ Utopia, pg. 208; Vtopia, pgs. 380-381.

${ }^{305}$ Utopia, pg. 148; Vtopia, pg. 319.
} 
quanto à exportação de produtos que há que fazer, mas vale que sejam eles a ocupar-se disso que confiá-lo a outros; deste modo, não só conseguem manter conhecimentos algum tanto alargados de povos que vivem à sua volta, como também não perdem a prática e a experiência das artes do mar. ${ }^{306}$

Elementos físicos adicionais que parecem indicar pontos de proximidade entre a Política e a Utopia dizem respeito à cidade de Amauroto. Amauroto ${ }^{307}$ é a capital (imagem fantasmagórica de Londres), pois foi lhe concedida a honra de sediar o senado; está localizada no centro da ilha, na encosta de uma montanha (que a protege dos ventos) sendo atravessada pelo rio Anidro $^{308}$ (que lhe dá acesso ao mar) e ligada à outra margem por uma ponte de pedra ${ }^{309}$. Além do Anidro, "há (...) um outro rio, esse relativamente pequeno, mas muito ameno e agradável; jorra ele do próprio monte em que a cidade está implantada, corre em declive pelo meio dela e mistura-se com o Anidro" ${ }^{, 310}$. Este pequeno rio tem a nascente e o cimo fortificados, de modo a não ser contaminado ou ter o seu curso desviado em caso de guerra. Fortificada também é a cidade, rodeada de muralhas e "guarnecida com torres e ameias" "311. Todos estes pontos coincidem com recomendações de Aristóteles, que considera que a cidade deveria ser um centro para todo o território ${ }^{312}$, deveria se inclinar levemente para o leste ${ }^{313}$ (enquanto Amauroto está na encosta de uma montanha), ter garantido um bom suprimento de água mesmo durante os períodos de guerra ${ }^{314}$ e ser protegidas por

\footnotetext{
${ }^{306}$ Utopia, pg. 184; Vtopia, pg. 353.

307 Utopia, pgs. 112, 116-118 ; Vtopia, pgs. 292, 295-297. Amauroto [Amaurotum] tem um campo de significação que, segundo Surtz, abrange os seguintes termos: "cidade fantasma", "cidade sombria", "cidade enevoada" ou mesmo "miragem". Utopia, pg. 388.

${ }^{308}$ Utopia, pg. 116; Vtopia, pg. 296.

${ }^{309}$ Utopia, pg. 118; Vtopia, pg. 296-297.

${ }^{310}$ Utopia, pg. 118; Vtopia, pg. 297.

${ }^{311}$ Utopia, pg. 118; Vtopia, pg. 297.

${ }^{312}$ Pol. 1330a 34-36.

${ }^{313}$ Pol. 1330a 38-41.

${ }^{314}$ Pol. 1330b 4-7.
} 
muralhas, torres e quaisquer outros recursos que possam desencorajar possíveis invasores $^{315}$

É possível, portanto, notar que há vários elementos nos quais pode-se reconhecer confluências entre a Política e a Utopia no que diz respeito a aspectos físicos do território e da cidade. Algo semelhante se dá no que se refere ao sentido ético-político da autárqueia, embora o fato de alguns pontos de aproximação serem de caráter bastante geral por vezes torne difícil afirmar de maneira absoluta que a referência que More tinha em mente fosse Aristóteles. Dentre os pontos de aproximação listados por White, interessam-nos aqui três: a felicidade, a virtude, a justiça, todo eles abarcados pela noção de bem comum.

No que se refere à noção abrangente de bem comum, White se limita inicialmente a comprovar sua presença na Política e em sustentar que ela é suficientemente semelhante à noção de interesse público presente na Utopia apoiandose, para tanto, em alguns exemplos selecionados (como quando o personagem More diz que como conselheiro de um rei Hitlodeu poderia servir ao interesse público) e na explicação do conceito aristotélico por Ernest Barker: "Este interesse comum, deve-se notar, não é apenas ou principalmente econômico: é o interesse em se alcançar uma vida boa (antes que confortável); e exige para sua satisfação aquelas instituições, tais como um sistema de justiça, que são necessárias para tal vida" ${ }^{\text {316 }}$. No entanto, White propõe que o exame da semelhança seja aprofundado por meio da consideração dos conceitos de felicidade, virtude (ou bondade) e justiça tal com aparecem em ambas as obras.

Já discutimos extensamente a presença do conceito de felicidade na Utopia ao abordarmos sua relação com o pensamento político platônico. Se antes foi possível

\footnotetext{
${ }^{315}$ Pol. 1330b 32-1331a 18.

${ }^{316}$ BARKER apud WHITE, “Aristotle and Utopia”, pg. 649.
} 
comprovar que sua ligação com o prazer não o incompatibilizava com as preocupações ético-políticas de Platão em colocar os prazeres dos sentidos sob o controle da razão (uma vez que se tratava de um prazer que consistia na contemplação da verdade e em uma vida ativa virtuosa), resta agora verificar se há algum choque com a concepção aristotélica ou se é possível a aproximação. O caminho seguido por White em sua discussão é semelhante ao que percorremos anteriormente: partindo do fato de que Aristóteles recusa que a vida de prazeres seja uma vida feliz, ele problematiza inicialmente a possibilidade de aproximação para em seguida demonstrar que efetivamente há uma semelhança maior do que se poderia imaginar.

Com efeito, na Ética nicomaquéia Aristóteles define a felicidade como sendo "uma atividade da alma em consonância com a virtude (...) em uma vida completa",317 por parte daquele que "está suficientemente provido de bens exteriores"318, enquanto que na Política ele afirma de maneira mais sintética que "a felicidade é a realização e o perfeito exercício da virtude״,319. Apoiando-se, então, na distinção utopiana entre prazeres verdadeiros e falsos (que considera semelhante à distinção aristotélica entre prazeres naturais e não-naturais que se encontra no capítulo 5 do livro VIII da Ética nicomaquéia), White nota que os prazeres recusados por Aristóteles também o são pelos utopianos, enquanto que a concepção que estes últimos têm acerca dos verdadeiros prazeres não apenas concorda em pontos importantes com a definição aristotélica de virtude, como ainda, pela inclusão da contemplação da verdade como constitutiva da felicidade, se aproxima da afirmação feita por Aristóteles no livro $\mathrm{X}$ da Ética

\footnotetext{
${ }^{317}$ Ét. nic. 1098a 16-18. A formulação "vida completa" significa aqui o mesmo que "ao longo de toda a vida".

${ }^{318}$ Ét. nic. 1101a 16.

${ }^{319}$ Pol. 1332a 9.
} 
nicomaquéia $^{320}$, segundo a qual a sabedoria teorética (contemplação) é a forma de vida mais prazerosa e feliz.

Mas se, na medida mesma em que nos dois casos observa-se uma ostensiva valorização da virtude (e também da razão), há uma proximidade significativa no que se refere à concepção de felicidade, serão suficientemente semelhantes também as respectivas concepções acerca da virtude? Neste caso não se pode deixar de reconhecer que há diferenças importantes. Como se sabe, Aristóteles chega à identificação entre felicidade e virtude justamente ao tentar precisar um pouco mais o conceito de felicidade:

Mas dizer que a felicidade é o sumo bem talvez pareça uma banalidade, e falta ainda explicar mais claramente o que ela seja. Tal explicação não ofereceria grande dificuldade se pudéssemos determinar primeiro a função do homem. Pois, assim como para um flautista, um escultor ou um pintor, e em geral para todas as coisas que têm uma função ou atividade, considera-se que o bem e o "bem feito" residem na função, o mesmo ocorreria com o homem se ele tivesse uma função. ${ }^{321}$

Descartadas a vida de nutrição e crescimento (pois ela é compartilhada com as plantas) e a vida de percepção (pois parece ser comum a todos os animais), resta como única resposta possível "a vida ativa do elemento que tem um princípio racional",322, de modo que aí, no uso da razão, deve estar a felicidade humana - desde que, como acrescenta Aristóteles, este uso se dê "em consonância com a virtude",323.

Mas como o uso da razão pode estar vinculado à virtude? Ora, no âmbito da ética "é necessário investigar o que concerne às ações, como devemos praticá-las"324; e a este respeito "o que por primeiro se deve reconhecer é que tais coisas são ${ }^{320}$ Ét. nic. 1177a 12-1177b 4.

${ }^{321}$ Ét. nic. 1097b 22-28.

${ }^{322}$ Ét. nic. 1098a 3-4.

${ }^{323}$ Ét. nic. 1098a 15-16.

${ }^{324}$ Ét. nic. 1103b 29-30. 
naturalmente corrompidas por falta e por excesso",325, de modo que ambos devem ser evitados, buscando-se a mediedade ${ }^{326}$. Como "as virtudes não se engendram nem naturalmente nem contra a natureza", mas sim "por que somos naturalmente aptos a recebê-las" 327 , é então necessário que o aperfeiçoamento humano se dê pelo hábito - o que significa que, para Aristóteles as virtudes são adquiridas por meio de sua prática contínua, do mesmo modo como "os homens tornam-se construtores construindo casas e tornam-se citaristas tocando cítara"328.

E o hábito assim adquirido é hábito de quê exatamente? Aristóteles diz que

do abster-se dos prazeres, tornamo-nos temperantes; tornados temperantes, somos os mais capazes de abster-nos deles. Igualmente com a coragem: habituados a desprezar as coisas temíveis e a suportá-las, tornamo-nos corajosos; tornados corajosos, seremos os mais capazes de suportar as coisas temíveis. ${ }^{329}$

Esta capacidade é uma disposição. Ser capaz de se abster de prazeres corporais sem sofrer por isso (ou seja, ser temperante) equivale a ter a disposição de se abster destes prazeres, o mesmo ocorrendo capacidade de suportar coisas temíveis (ser corajoso) e em tudo aquilo que for equivalente quanto às demais virtudes ${ }^{330}$.

Entretanto, se a virtude pertence ao gênero das disposições, é necessário ainda estabelecer que tipo de disposição é a virtude. A este respeito

deve-se frisar, então, que toda virtude aprimora o bom estado e desempenha a função daquilo mesmo de que é virtude. Por exemplo, a virtude do olho torna bons o olho e sua

\footnotetext{
${ }^{325}$ Ét. nic. 1104a 10-13.

${ }^{326}$ Ét. nic. 1104 a 25.

${ }^{327}$ Ét. nic. 1103a 24-25.

${ }^{328}$ Ét. nic. 1103 a 32.

${ }^{329}$ Ét. nic. $1104 \mathrm{a} 32-1104 \mathrm{~b} 2$.

${ }^{330}$ A determinação da virtude como disposição envolve ainda a análise desenvolvida no capítulo 4 do livro II, mediante a qual Aristóteles comprova que ela não é nenhum dos outros dois tipos de estado da alma, a saber, emoção e capacidade. Para o que nos interessa aqui, porém, o que desenvolvemos no corpo do texto deve bastar.
} 
função, pois é mediante a virtude do olho que vemos bem. (...) Logo, se assim é a respeito de tudo, a virtude do homem também será a disposição graças à qual ele se torna um homem bom e graças à qual desempenha bem a função de si próprio. ${ }^{331}$

E a virtude torna um homem bom e permite que ele desempenhe bem sua função porque ela tem em vista a mediedade a que nos referimos antes.

Por exemplo, é possível temer, ter arrojo, ter apetite, encolerizar-se, ter piedade e, em geral, aprazer-se e afligir-se muito e pouco, e ambos de modo não adequado; o quando deve, a respeito de quais, relativamente a quem, com que fim e como deve é o meio termo e o melhor, o que justamente é a marca da virtude. Similarmente, há excesso, falta e meio termo no tocante às ações. A virtude diz respeito a emoções e ações, nas quais o excesso erra e a falta é censurada, ao passo que o meio termo acerta e é louvado: acertar e ser louvado pertencem à virtude. Portanto, a virtude é certa mediedade, consistindo em ter em mira o meio termo. ${ }^{332}$

E, por fim, se a virtude pode levar à mediedade, é porque ela consiste justamente no exercício da razão como deliberação na recusa do excesso e da falta, de modo que Aristóteles poderá dizer que "a virtude é, portanto, uma disposição de escolher por deliberação, consistindo em uma mediedade relativa a nós, disposição delimitada pela razão, isto é, como a delimitaria o prudente. É uma mediedade entre dois males, o mal por excesso e o mal por falta",333.

É possível perceber então que, na concepção aristotélica, a atividade virtuosa, ainda que não seja engendrada naturalmente, é de certa forma imanente ao ser humano. Se a virtude é a disposição graças à qual um homem se torna um homem bom e desempenha bem sua função, ela é, assim, necessária ao ser humano e permite que ele se realize. Ainda que o tornar-se virtuoso dependa da observação das pessoas prudentes e do desenvolvimento do hábito, a virtude aparece como a finalidade própria do homem

${ }^{331}$ Ét. nic. 1106a 15-25.

${ }^{332}$ Ét. nic. $1106 \mathrm{~b}$ 19-29.

${ }^{333}$ Ét. nic. 1106b 36-1107a 3. 
e, por isso, não depende de motivos adicionais, externos a ela própria, que a justificassem como algo a ser buscado.

Sabemos que não é esta a concepção utopiana. Como assinalamos antes, os utopianos "nunca discutem sobre o problema da felicidade sem tirarem alguns princípios da religião e sem os associarem com a filosofia que se serve do raciocínio, pois sem os primeiros consideram que a razão por si só é falha e sem forças para indagar a verdadeira felicidade" ${ }^{334}$. A felicidade como virtude, embora constitua o verdadeiro prazer, não parece, na concepção dos utopianos, poder se justificar apenas por si mesma e pelo exame racional, precisando de princípios religiosos adicionais (mesmo que alcançados racionalmente) que lhe deem sustentação. Na ausência destes últimos

\begin{abstract}
declaram eles sem hesitação, ninguém haverá tão estúpido que não se aperceba que tem de, por todos os meios ao seu alcance, procurar o prazer. Uma coisa, porém, deve acautelar: que um prazer menor não impeça um maior ou que não se deixe levar por um que, por sua vez, em retaliação, lhe provoque sofrimento. Efectivamente, seguir o caminho árduo e penoso da virtude, e não somente afastar-se das doçuras da vida, mas também aceita voluntariamente o sofrimento, do qual não se espera qualquer fruto (que fruto se poderá realmente colher, se depois da morte nada se consegue, quando atravessamos a vida sem satisfações, ou seja, em sofrimento?) dizem eles, com razão, que é uma coisa das mais incompreensíveis. ${ }^{335}$
\end{abstract}

Mesmo que a frase seguinte diga que a felicidade, para eles, não está em qualquer prazer, mas apenas nos prazeres bons e honestos, e que o próximo parágrafo comece pela definição de virtude como "viver segundo a natureza", o texto diz diretamente que

\footnotetext{
${ }^{334}$ Utopia, pg. 160; Vtopia, pg. 303. Os princípios mencionados no trecho são os de que "a alma é imortal e por benevolência de deus foi feita para a felicidade; depois desta vida, à virtude e às boas acções estão destinados prémios, aos crimes estão destinados castigos".

${ }^{335}$ Utopia, pg. 162; Vtopia, pgs. 330-331.
} 
o "caminho árduo e penoso da virtude" não se justifica sem a promessa religiosa de compensações na forma de prêmios divinos recebidos após a morte. ${ }^{336}$

White considera que as ideias de More a respeito da natureza da virtude não estão tão claramente apresentadas na Utopia, mas parecem consistir em que "o comportamento virtuoso se origina de crenças adequadas, embora certas emoções e possivelmente bons hábitos também contribuam"337. Porém, mesmo que se atribua algum papel ao hábito, não é possível negar que haja, aqui, uma diferença substancial entre a concepção aristotélica da virtude e aquela presente na Utopia.

O último dentre os pontos que, para White, compõem o âmbito do bem comum é o da justiça. Neste caso o elemento mais importante que parece indicar proximidade

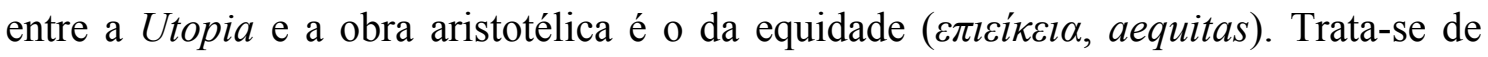
uma questão desenvolvida por Aristóteles na Ética nicomaquéia e na Retórica no que diz respeito a seus elementos mais fundamentais ${ }^{338}$. Na primeira, perto do final da discussão sobre a justiça, ele diz que é necessário tratar da equidade e do equitativo e das respectivas relações com a justiça e o justo, pois parece haver certa confusão a este respeito.

[O] equitativo, embora superior a uma espécie de justiça, é justo, e não é como coisa de classe diferente que é melhor do que o justo. A mesma coisa, pois, é justa e equitativa, e, embora ambos sejam bons, o equitativo é superior. O que faz surgir o problema é que o equitativo é justo, porém não o legalmente justo, e sim uma correção da justiça legal. A razão disto é que toda lei é universal, mas a respeito de certas coisas não é possível fazer uma afirmação universal que seja correta. Nos casos, pois, em que é necessário

\footnotetext{
${ }^{336}$ White ("Aristotle and Utopia", pg. 655) aponta ainda outros elementos semelhantes, como a crença de que as almas dos antepassados mortos testemunhem mesmo as ações secretas de cada pessoa (Utopia, pg. 224; Vtopia, pg. 396), ou a referência ao temor pelas divindades como sendo "o maior e quase o único incentivo para as virtudes" (Utopia, pg. 234; Vtopia, pg. 406.).

337 WHITE, "Aristotle and Utopia", pg. 655.

${ }^{338}$ Os trechos das obras de Aristóteles que abordamos em seguida são todos (acompanhados de ainda outros) listados e discutidos por Andrew Majeske em seu livro Equity in English Renaissance Literature: Thomas More and Edmund Spenser.
} 
falar de modo universal, mas não é possível fazê-lo corretamente, a lei considera o caso mais usual, se bem que não ignore a possibilidade de erro. E nem por isso tal modo de proceder deixa de ser correto, pois o erro não está na lei, nem no legislador, mas na natureza da própria coisa, já que os assuntos práticos são dessa espécie por natureza. Portanto, quando a lei se expressa universalmente e surge um caso que não é abrangido pela declaração universal, é justo, uma vez que o legislador falhou e errou por excesso de simplicidade, corrigir a omissão (...). Por isso o equitativo é justo, superior a uma espécie de justiça - não à justiça absoluta, mas ao erro proveniente do caráter absoluto da disposição legal. E essa é a natureza do equitativo: uma correção da lei quando ela é deficiente em razão de sua universalidade. ${ }^{339}$

Trata-se, portanto, da necessidade de se reconhecer um outro nível de existência da justiça, para além da formalização nas leis. Por um lado, na Retórica a questão aparece como objeto de considerações adicionais um pouco mais estritas, com indicações dos critérios que deve guiar a equidade:

\begin{abstract}
A equidade deve ser aplicada às ações perdoáveis; e nos deve fazer distinguir entre malfeitos, por um lado, e enganos ou infortúnios, por outro (um infortúnio é um ato que não se deve à perversidade, mas tem resultados inesperados; um engano é um ato que também não se deve à torpeza, mas tem resultados que poderiam ter sido esperados; um malfeito tem resultados que poderiam ter sido esperados, mas que são devidos à torpeza). A equidade nos ordena que sejamos misericordiosos com a fraqueza da natureza humana; que pensemos menos sobre as leis que sobre o homem que as formulou, e menos no que ele disse do que no que ele quis dizer; que não consideremos as ações dos acusados tanto quando sua escolha, nem este ou aquele detalhe tanto quanto toda a história; que não perguntemos o que um homem é agora, mas o que ele foi sempre ou pela maior parte do tempo. Ela nos ordena que lembremos dos benefícios mais que nos danos, e dos benefícios recebidos mais que nos conferidos; que sejamos pacientes quando somos prejudicados; que resolvamos uma disputa pela negociação e não pela força; que prefiramos a arbitragem à litigação - pois um árbitro se orienta pela equidade de um caso, e um juiz, pela lei, e a arbitragem foi inventada com o propósito de garantir pleno poder à equidade. ${ }^{340}$
\end{abstract}

Por outro lado, porém, é interessante notar que ela volta a aparecer, e de forma mais ampla, na Política, ainda que não seja mencionada diretamente. Isto ocorre no capítulo 15 do Livro III, quando, em meio à discussão sobre as vantagens e

${ }^{339}$ Ét. nic. $1137 \mathrm{~b} 7-27$.
${ }^{340}$ Ret. $1374 \mathrm{~b} 4-24$. 
inconvenientes da realeza, Aristóteles examina se é mais vantajoso ser governado pelo melhor homem ou pelas melhores leis:

Os defensores da realeza sustentam que as leis falam apenas em termos gerais e não podem atender às circunstâncias; e que é absurdo, para qualquer ciência, submeter-se a leis escritas. No Egito o médico tem permissão de alterar seu tratamento depois do quarto dia, mas se o fizer antes, ele assume o risco. Portanto é claro que um governo que aja de acordo com leis escritas claramente não é o melhor. Entretanto, é certo que o governante não pode prescindir do princípio geral que existe na lei; e que é melhor governante aquele que é livre de paixões que aquele em quem elas são inatas. Enquanto a lei não tem paixões, a paixão deve sempre influenciar o coração do homem. Sim, deve-se responder, mas então por outro lado um indivíduo será mais capaz de deliberar em casos particulares. ${ }^{341}$

O termo equidade (bem como diversas variantes e formas negativas) ocorre abundantemente por toda a Utopia, o que indica uma preocupação constante com esta questão. Duas destas ocorrências, porém, podem ser destacadas. A primeira delas se dá no momento em que Hitlodeu responde ao cardeal Morton por que ele considera que o furto não deveria ser punido com a morte e qual pena corresponderia ao bem comum.

O meu parecer, benigníssimo Padre, é de que é inteiramente iníquo tirar a vida por se ter tirado dinheiro. De facto, considero que a vida humana não pode colocar-se em pé de igualdade nem sequer com o conjunto dos bens de fortuna que se possuam. Se disserem que com tal castigo é vingada a violação da lei, não o dinheiro..., que é isso? não haverá razão para lhe aplicar a sentença de que "máximo de direito, máximo de injustiça"? De facto, não há que aceitar nem leis à maneira de Mânlio, para brandir a espada à mais pequena infracção, nem as máximas dos estóicos, que consideram iguais todos os crimes, a ponto de não estabelecerem a mínima diferença entre matar um homem e subtrair-lhe uma moeda. Entre uma coisa e outra, se para algo vale a equidade, não há qualquer semelhança ou afinidade. ${ }^{342}$

\footnotetext{
${ }^{341}$ Pol. 1286a 10-22.

${ }^{342}$ Utopia, pg. 72; Vtopia, pgs. 253-254, grifos meus.
} 
Como aponta White, as observações de Hitlodeu vão no sentido das de Aristóteles, problematizando um legalismo opressivo e cego. Também alguns traços de Utopia atendem a estas preocupações, como os fatos de que para a maioria dos crimes "não há penas previstas por lei, mas compete ao senado determinar, de cada vez, qual o castigo que melhor corresponda ao juízo sobre a gravidade do crime" ${ }^{\text {343 }}$, e de que as leis gerais existentes são muito poucas e devem ser simples de interpretar ${ }^{344}$.

A segunda ocorrência que apresenta maior interesse localiza-se após a descrição de Utopia por Hitlodeu, no início da peroração. Neste trecho, como destaca Majeske, a equidade aparece referida ao comunismo utopiano ${ }^{345}$.

Descrevi-vos (...) a forma de organização que tem esta República, forma essa que considero ser não só a melhor, mas a única que possa reivindicar o nome de república. Aliás, é sabido que, se noutro lugar se fala de bem público, apenas se cuida do bem privado. Aqui, pelo contrário, como nada existe que seja particular, é o bem público que se toma a peito. (...) Ora, aqui, em que tudo é de todos, até porque há o cuidado de manter os celeiros públicos abastecidos, ninguém tem dúvidas de que não virá a faltar nada do que seja necessário na vida privada. De facto, não há distribuição malevolente das coisas nem alguém passa necessidade nem anda na mendicidade e, embora ninguém seja dono de coisa alguma, nem por isso deixam todos de ser abastados. Na realidade, quem pode ser mais abastado do que aquele que vive totalmente sem qualquer ansiedade, de ânimo desanuviado e tranquilo? (...) Gostaria que alguém, com o mesmo sentido de equidade, ousasse aqui comparar a justiça de outros povos, nos quais eu até daria a vida por descobrir qualquer vestígio que fosse de justiça e equidade. ${ }^{346}$

Aqui parece haver um afastamento em relação aos sentidos atribuídos à equidade por Aristóteles. Não se trata da distância entre a universalidade da lei e a concretude do caso particular. A equidade a que Hitlodeu apela neste ponto diz respeito ao comunismo utopiano como realização da justiça. Ora, Aristóteles é bem claro em sua recusa do

\footnotetext{
${ }^{343}$ Utopia, pg. 190; Vtopia, pg. 361.

${ }^{344}$ Utopia, pg. 194; Vtopia, pgs. 365-366.

${ }^{345}$ Cf. Majeske, Equity in English Renaissance Literature, pgs. 85-91.

${ }^{346}$ Utopia, pgs. 236-238; Vtopia, pgs. 409-410.
} 
comunismo ao criticar a República ${ }^{347}$. Porém, pode ser possível traçar, com relação a este ponto, uma aproximação entre a Utopia e a obra aristotélica em pelo menos dois aspectos.

Em primeiro lugar, assim como Platão, Aristóteles considera que a justiça é o valor político fundamental, o que é dito por ele já no livro I da Política: “a justiça é o vínculo dos homens nas cidades; pois a administração da justiça, que é a determinação do que é justo, é o princípio da ordem na sociedade política" ${ }^{\natural 48}$. Nestes termos, a justiça aparece como tendo um duplo sentido político, sendo por um lado a condição de existência da comunidade política, enquanto que por outro lado ela é o critério mesmo pelo qual se pode avaliar a relação entre a cidade e sua finalidade, o bem comum. $\mathrm{O}$ primeiro aspecto é destacado por Francis Wolff:

[D]esde que [em uma comunidade] há vários indivíduos e algo em comum entre eles, põe-se um problema, que é o problema da justiça. Com efeito, "toda colocação em comum funda-se na justiça" (Ét. nic., VII, 9, 1241b 15). Eis por que a justiça não é uma virtude entre as outras, mas a virtude da comunidade, aquela que regula as relações entre seus membros, graças à qual uma comunidade existe ou pode continuar existindo. ${ }^{349}$

\footnotetext{
${ }^{347}$ As críticas de Aristóteles são resumidas por George Logan: "Aristóteles critica severamente o comunismo da República a partir de várias bases. A comunidade de esposas e filhos não resultaria, como Platão imagina, em uma maior harmonia, mas no enfraquecimento dos vínculos comunais: 'todo filho será igualmente o filho de todo pai; e o resultado será que todo filho será igualmente negligenciado por todo pai' (Pol. II. 1261b). A comunidade da propriedade é desaconselhável por cinco razões (1261b1264a). E primeiro lugar, ela enfraqueceria a iniciativa. Em segundo lugar, ela eliminaria as oportunidades para a prática da virtude da liberalidade. Em terceiro lugar, ela privaria os homens do prazer legítimo da posse e daquele derivado da liberalidade. Em quarto lugar, ela não aumentaria a concórdia, pois muitos dos males da dissensão geralmente atribuídos à propriedade privada de fato 'nascem da perversidade da natureza humana': 'Realmente pode-se observar o fato de que aqueles que têm propriedade em comum e compartilham seu cuidado estão muito mais frequentemente em desacordo um com o outro do que aqueles que têm a propriedade separadamente" (The meaning of More's Utopia, pgs. 208-209).

${ }^{348}$ Pol. 1253a 37-38.

${ }^{349}$ Wolff, Aristóteles e a política, pg. 41.
} 
A condição de critério, por sua vez, é apontada por Marilena Chauí: “A finalidade da política sendo o bem comum e a vida justa, o valor essencial da política, aquele valor que serve para medir todos os demais valores da Cidade, é a justiça"350.

Assim, ainda que por uma forma recusada por Aristóteles, a Utopia, aos olhos de Hitlodeu, realiza a justiça da forma mais plena. Isto é dito por ele já no final do livro I:

Na realidade, meu caro More (para te dizer a verdade que levo no coração), me parece que em toda parte em que há propriedade privada, em que todos medem tudo por dinheiro, dificilmente alguma vez aí se poderá chegar a promover a justiça de Estado ou a prosperidade; a não ser que se presuma que se actua com justiça quando o que é excelente chega aos piores indivíduos ou que há prosperidade quando tudo é repartido entre pequeno número de indivíduos, que com nada se sentem saciados, enquanto os outros dão condenados à miséria. ${ }^{351}$

Assim, diferente de Aristóteles, que considerava inviável e indesejável qualquer tentativa de supressão e coletivização da propriedade privada, Hitlodeu considera que sem o comunismo não é possível realizar-se efetivamente aquela mesma justiça que seria a virtude da comunidade e o valor essencial da política, uma vez que a desigualdade existente na Europa estabelecia um contraste entre as condições de vida e as perspectivas dos ricos e dos pobres, que de forma alguma poderia ser considerada justa.

Em segundo lugar, não deixa de haver ainda outro aspecto curioso em que parece que há proximidade com Aristóteles. O trecho da Política que citamos anteriormente, recolocando o tema da equidade no âmbito da atividade política, abordava a questão de se decidir se é mais vantajoso ser governado pelo melhor homem (um monarca) ou pelas melhores leis. Como mostra Francis Wolff, Aristóteles não opta por nenhuma destas alternativas, considerando que, em vista da equidade, a via

\footnotetext{
${ }^{350}$ Chauí, Introdução à história da filosofia, pg. 470.

${ }^{351}$ Utopia, pg. 102; Vtopia, pg. 282, tradução modificada.
} 
apropriada não está nem na frieza das leis, nem na passionalidade do monarca, mas sim na assembleia do povo encarregada de cuidar dos assuntos políticos pelo exercício dos poderes de deliberar e julgar. Isto se dá porque os poderes de deliberar e julgar não exigem uma competência técnica particular (pois não se referem à administração de um domínio específico ou à condução de uma ação específica), mas se referem à tomada de decisões justas sobre questões que dizem respeito à comunidade e, por isso, são da competência desta última:

Para deliberar e julgar da melhor maneira, a multiplicidade dos pontos de vista é requerida, compensada pela unidade do corpo da assembleia. A assembleia do povo é justamente esta unidade de uma multiplicidade. A pluralidade de opiniões pode realmente paralisar a ação ou tornar a administração incoerente, mas enriquece a deliberação e o julgamento. ${ }^{352}$

Wolff nota que não pode deixar de emergir aqui uma dúvida: por que a ordem constituída pela assembleia do povo forma uma unidade que é superior a cada cidadão tomado individualmente? Recorrendo a outros textos, ele procura fornecer algumas razões. A primeira delas estaria no fato de que, na medida em que a cidade, para Aristóteles, não é uma união constituída a partir de interesses, mas sim a partir de vínculos de amizade, fica garantida a unidade da comunidade. "Em uma cidade assim definida, a soberania do povo reunido em assembleia pode exercer-se em benefício do interesse geral"353. A segunda razão, porém, refere-se a um aspecto que tem uma relação ainda mais direta com a equidade. Trata-se do que Wolff chama de "um princípio antropológico":

\footnotetext{
${ }^{352}$ Wolff, Aristóteles e a política, pg. 137.

${ }^{353}$ Wolff, Aristóteles e a política, pg.
} 
Somente a deliberação coletiva permite ao homem tal como ele é inserir sua ação no mundo tal como ele vai. (...) A política está ligada à contingência do mundo sublunar; nele não se pode, contrariamente àquilo que pode fazer o astrônomo, abranger em uma fórmula universal o conjunto dos casos particulares; a história dispõe deles. (...) A deliberação coletiva permite resolver a antinomia [entre o governo pelo melhor homem e o governo pelas melhores leis]. Insensível à singularidade das paixões individuais, ela está adaptada aos domínios "onde a lei absolutamente não é capaz de decidir ou de decidir bem" (1286a 24). É necessário deliberar sobre aquilo que nenhuma lei pôde ou possa prever, isto é, casos particulares (...). Vê-se portanto aquilo que tornaria a deliberação coletiva inoperante ou supérflua: seria uma lei perfeita ou um monarca sem paixão. É a quimera. Uma lei não é perfeita senão no mundo da necessidade, isto é, no céu; um monarca sem paixão seria um deus, e sabe-se que os deuses no céu dispensam a política. A deliberação coletiva realiza de alguma maneira a essência da condição humana, que é política. ${ }^{354}$

A terceira razão, por sua vez, está relacionada ao "vínculo necessário entre a cidade e o mundo":

A política não se opõe somente à generalidade das leis, mas também à ciência do especialista e é por isso que ela é um caso de "deliberação": esta última exige não um saber, mas experiência e prudência. O objeto sobre o qual se delibera em política não é de fato cognoscível, mas somente "opinável", já que não existe necessariamente, mas pode ser diferente (caso contrário, não se discutiria a respeito dele) - e depende justamente da decisão dos homens que seja de um ou de outro modo. A assembleia do povo, mosaico de opiniões contraditórias do qual deve emanar uma só decisão, é o espaço mais bem adaptado à deliberação, que supõe a palavra pública e a contradição, e visa um futuro que não passa de um conjunto de possíveis inconsistentes dos quais um só poderá se atualizar. É por outra parte o lugar em que se somam as experiências individuais, e nenhuma experiência é transmissível ou repetível. A experiência é de fato uma virtude cumulativa; é a qualidade própria do idoso por oposição ao moço; é, pelas mesmas razões, antes a virtude de uma coletividade que de um indivíduo. No singular talvez se tenha mais competência, no plural se tem mais experiência(s). ${ }^{355}$

Por fim, Wolff destaca ainda que o poder exercido pela assembleia envolve também julgar, isto é, “decidir, por meio de um julgamento singular, em uma circunstância particular, conforme uma lei demasiadamente geral, um único caso que não se assemelha a nenhum outro". Assim como no caso da avaliação das obras de arte,

\footnotetext{
${ }^{354}$ Wolff, Aristóteles e a política, pgs. 139-140.
}

${ }^{355}$ Wolff, Aristóteles e a politica, pgs. 140-141. 
a multidão é quem pode cumprir melhor a tarefa, e isto por dois motivos: em primeiro lugar, ela é composta por um grande número de pontos de vista; em segundo lugar, esta multiplicidade é adequada a um objeto que (seja ele político ou estético) apresenta uma forma de complexidade tal que ele não pudesse acabar de ser "discernido"356.

Em outros termos, e como em Kant, aquilo que não pode ser sabido e somente pode ser julgado é sempre incompletamente conhecido do lado do objeto, muito embora julgado com satisfação do lado do sujeito. É no silêncio inevitável da lei, lá onde o particular não pode jamais se deduzir do geral, que se deve aplicar o julgamento, isto é, como diz Kant, "pensar o particular”. (...) Ao contrário do conhecimento ou da ação, que exigem a competência do "perito", o julgamento exige a totalidade dos pontos de vista possíveis e depende apenas do recurso a todas as incompetências reunidas.

(...) A questão do valor em política é sempre uma questão de destinação e mesmo de destinatário. Vimos, por exemplo, que não convém classificar os regimes do ponto de vista do "ator", do "destinador", ou do "produtor", em resumo, "do lado do mais forte ou de seus interesses" - mas segundo a resposta à questão "em vista de quem se governa?" (...). A política é uma arte que deve ser julgada por aqueles a quem ela é destinada, isto é, por todos unidos, pois todo regime político legítimo é destinado à unidade de todos. ${ }^{357}$

Já nos referimos antes ao fatos de que em Utopia há poucas leis e de que para a maioria dos crimes não há penas previstas por lei, cabendo ao senado a determinação da punição correspondente à gravidade do crime. A obra não fornece detalhes sobre as instituições e práticas de governo. O trecho sobre as magistraturas, por exemplo, apresenta-as nos seguintes termos:

Cada trinta famílias elege, todos os anos, um representante que designam na sua primitiva língua por sifogranto e em língua mais recente filarco. Cada dez sifograntos, com suas famílias, preside um traníboro na língua de antigamente, hoje chamado protofilarco. Finalmente, todos os sifograntos, que são duzentos, depois de jurarem que escolherão aquele que considerem mais útil, em votos secretos elegem como príncipe

\footnotetext{
${ }^{356}$ Wolff, Aristóteles e a política, pg. 141.

${ }^{357}$ Wolff, Aristóteles e a política, pgs. 142-143.
} 
um de entre quatro que o povo tiver designado. De facto, cada um dos quatro bairros da cidade escolhe um representante para fazer parte do Senado. ${ }^{358}$

Apesar de, como apontamos antes, haver uma evidente semelhança com a República no fato de que só podem ser eleitas para estas magistraturas pessoas da classe dos acadêmicos, é preciso reconhecer que há também importantes diferenças que indicam um amplo espaço de participação popular. Em primeiro lugar, a estrutura sociopolítica não é tão rígida quanto na República, onde cada um pertence a apenas uma classe. A passagem para a classe dos acadêmicos é concedida àqueles que "por recomendação dos sacerdotes, e por voto secreto dos sifograntos, o povo tenha reconhecido ser oportuno conceder dispensa [do trabalho] sem limite de tempo para se dedicarem ao estudo da ciência"359. Caso haja alguém que não corresponda às esperanças que lhe foram depositadas, o processo é revisto e a pessoa retorna aos trabalhos manuais. O mais comum, porém, é que ocorra o contrário, pois "não é raro que um trabalhador manual, durante as horas de descanso, se consagre às letras com tal diligência e obtenha tal aproveitamento que seja dispensado do seu mester para passar à classe dos letrados" ${ }^{360}$. Em segundo lugar, apesar do cargo de príncipe ser vitalício e da situação dos traníboros ser um tanto indefinida (“os traníboros ficam sujeitos à eleição anual, mas não são substituídos senão por motivo sério"), "os restantes magistrados são todos anuais"361. Por fim, há toda uma série de cuidados para se garantir que o tratamento das questões de interesse público possa ser acompanhado cuidadosamente pelo povo ou mesmo submetido diretamente à deliberação da Assembleia do Povo:

\footnotetext{
${ }^{358}$ Utopia, pg. 122; Vtopia, pg. 300.

${ }^{359}$ Utopia, pg. 130; Vtopia, pg. 306.

${ }^{360}$ Utopia, pg. 132; Vtopia, pg. 307.

${ }^{361}$ Utopia, pg. 122; Vtopia, pg. 300.
} 
Cada três dias, e mesmo mais frequentemente se o assunto assim o exigir, os traníboros reúnem-se em conselho com o príncipe. Deliberam sobre matérias de interesse público, decidem de questões privadas (se alguma houver) (...). No Senado assistem sempre dois sifograntos, cada dia diferentes, e está acautelado que nada seja sufragado senão o que é de interesse público e que além disso não se toma decisão final sem terem passado três dias sobre a sua discussão no Senado. Tomar decisões relativas a interesses públicos fora do Senado ou fora das Assembleias do Povo é considerado crime capital. Diz-se que tal lei foi instituída para não se cair na tentação de alterar a forma de governação, por conspiração do príncipe e dos traníboros que levasse a instituírem a tirania que serviria para oprimir o povo. Por isso mesmo, tudo o que é considerado de maior importância é levado às assembleias dos sifograntos, os quais o comunicam primeiro às famílias que representam e depois o debatem entre eles e só de seguida transmitem a sua deliberação ao Senado. Entretanto o assunto é levado ao conselho de toda a ilha. ${ }^{362}$

Assim, se a questão da equidade está presente na Utopia, é preciso reconhecer que ela emerge em uma forma que tanto recupera elementos da obra aristotélica, quanto desvia desta última e se coloca mesmo em uma posição crítica ao postular que a justiça só poderia se realizar da forma mais plena através do comunismo. Mesmo em relação à participação política parece haver no livro de More uma ampliação que só poderia ocorrer sob condições efetivamente comunistas, já que virtualmente todos são cidadãos no sentido aristotélico de detentores do direito de acesso às magistraturas, dado que a possibilidade de se tornar acadêmico está sempre colocada. Além disso, enquanto que para Aristóteles a felicidade plena (a vida virtuosa e justa) fica reservada apenas para alguns, na Utopia ela, por princípio, está aberta a todos.

${ }^{362}$ Utopia, pg. 122-124; Vtopia, pgs. 300-301. 
3. Nusquama Nostra: ${ }^{363}$ a Utopia como obra humanista

Ao tratar do contexto em que se inscreve a Utopia, é quase que incontornável discutir o humanismo em sua vertente britânica, assunto por demais controverso. E as dificuldades envolvidas levam a diferentes estratégias. Hanan Yoran, em seu livro sobre a Utopia e a República das Letras erasmiana, toma como ponto de partida uma confrontação entre as interpretações de Paul Oskar Kristeller e Hans Baron, que ele considera terem sido as mais influentes nos países de língua inglesa. Kristeller recusa como anacrônica e enganadora a concepção sobre o humanismo desenvolvida no séc. XIX, segundo a qual este equivaleria a "quase que qualquer tipo de preocupação com

363 Título original de Utopia. A expressão foi usada pelo próprio More e encontra-se em uma carta enviada por ele a Erasmo em setembro de 1516, a qual se inicia do seguinte modo: "Te envio nossa Lugar Nenhum, em nenhum lugar bem escrita" (Nusquama nostram, nusquam bene scriptam ad te mitto). Cf. Carta 6 "To Erasmus" In: More, Selected Letters, pg. 73 (Na tradução de Elizabeth Rogers a frase aparece traduzida para o inglês nos seguintes termos: "I am sending you my 'Nowhere', which is nowhere well writen"). A este respeito Kristeller faz o seguinte comentário: "Em várias cartas enviadas por More a Erasmo em 1516, quando lhe remeteu seu manuscrito, More não usa o título Utopia, referindo-se à obra como Nusquama (Terra de lugar nenhum). É bem possível que este fosse o título original (ainda não bem afinado) e que More tenha então adotado o título Utopia enquanto o livro estava no prelo, talvez a conselho de Erasmo. O título Nusquama pode ser claramente remetido ao final do nono livro da República de Platão, onde Sócrates declara que a república perfeita que ele e seus amigos estiveram descrevendo existe apenas em seu discurso, e em parte alguma na Terra (ges ge oudamou). Estou convencido de que More, na escolha de Nusquama como título original, foi inspirado por esta passagem de Platão. Erasmo nos diz que More se familiarizou com esta obra quando ainda muito jovem, mas vale a pena notar que a primeira edição impressa das obras de Platão em grego foi publicada por Aldus Manutius em 1513. Parece-me plausível que More tenha usado seu tempo livre em Flandres para reler $A$ República em grego e discuti-la com seus amigos. Isto não reduz de modo algum a originalidade de More, mas evidencia seu conhecimento a respeito de Platão e especialmente dos textos de Platão em grego. Pois na tradução de Ficino para o latim, que estava disponível impressa desde 1484, esta passagem crucial é vertida erroneamente (nusquam interius, em lugar de nusquam in terris)" (Kristeller, "Thomas More as a Renaissance Humanist”, pg. 10). 
valores humanos". Uma vez que o próprio termo não era utilizado durante o Renascimento, uma alternativa para o exame do problema poderia ser encontrada na determinação do sentido de outros a ele conectados, como humanista. Segundo Kristeller,

o termo humanista emergiu nas universidades italianas no jargão estudantil denotando umanista - como jurista, artista, legista - um professor ou estudante dos studia humanitatis. A expressão studia humanitatis foi usada por Cícero e seus contemporâneos como um nome para as disciplinas compreendidas pela educação liberal romana, e os humanistas começaram a usá-la neste sentido no final do séc. XIV. Na primeira metade do séc. XV, o sentido da expressão se estabilizou como o nome geral para um grupo específico de disciplinas - gramática, retórica, poesia, história e filosofia moral - que eram estudadas de acordo com os textos canônicos clássicos. ${ }^{364}$

Isto permite que Kristeller proponha então sua famosa definição do humanismo:

Assim, o humanismo renascentista não era algo como uma tendência ou sistema filosófico, mas antes um programa educacional e cultural que enfatizou e desenvolveu uma área de estudos importante, mas limitada. Esta área teve como centro um grupo de disciplinas cujo interesse primeiro não eram nem os clássicos nem a filosofia, mas poderíamos descrever aproximadamente como literatura. ${ }^{365}$

Neste sentido mais preciso, segundo Kristeller, o movimento humanista seria "o aspecto mais característico e geral do Renascimento italiano no campo intelectual”. Seu traço distintivo consistia em recorrer ao estudo dos clássicos em busca de um modelo ideal a ser imitado para o exercício de suas próprias atividades, profundamente “enraizadas nos costumes e instituições específicas da Itália medieval”366. Tratava-se não de eruditos em busca de eloquência por razões pessoais, mas antes de "retóricos

\footnotetext{
${ }^{364}$ Yoran, Between utopia and dystopia, p. 18

${ }^{365}$ Kristeller, El pensamiento renascentista e sus fuentes, p. 40

${ }^{366} \mathrm{Cf}$. Kristeller, El pensamiento renascentista e sus fuentes, pg. 122 e 131.
} 
profissionais" $" 367$; salvo raras exceções, “eram secretários de príncipes ou cidades ou mestres de gramática e retórica em universidades ou escolas secundárias”368. Por conta disso, teriam sido responsáveis por um incremento dos estudos da literatura grega ${ }^{369}$, bem como uma maior disponibilização de traduções de textos gregos para o latim, ampliando consideravelmente o número de leitores destes textos, uma vez que era relativamente pequeno o número de conhecedores do grego. Mas esta contribuição não se restringia aos gregos.

No caso de autores latinos, geralmente conhecidos na Idade Média, os humanistas lhes deram maior difusão por meio de numerosas cópias manuscritas e edições impressas, através de seus estudos gramaticais e antiquários, de seus comentários, bem como do desenvolvimento e da aplicação de uma crítica filológica e histórica. ${ }^{370}$

Estes estudos possibilitaram o desenvolvimento de uma epistolografia própria a partir da antiga ars dictaminis medieval, e de uma oratória distinta, cujas raízes entretanto remontam à ars arengandi, embora ambas difiram significativamente em termos de estilo. O mesmo se passa com a historiografia, herdeira da crônica medieval, que passa a unir o estilo elegante à crítica filológica rigorosa. Assim, embora não possa ser compreendido como um conjunto de teses, uma teoria ou um sistema filosófico particular, o humanismo teria sido um movimento identificável e de importância considerável. De forma que, diferente de alguns medievalistas que se apressam em negá-lo, para Kristeller, houve sem dúvida um Renascimento italiano. Entretanto, o seu surgimento não pode ser explicado pela oposição pura e simples a uma Idade Média "sombria", como querem alguns estudiosos do Renascimento, mas sim pelas

\footnotetext{
${ }^{367}$ Kristeller, El pensamiento renascentista e sus fuentes, pg. 122-123.

${ }^{368}$ Kristeller, El pensamiento renascentista e sus fuentes, pg. 127.

${ }^{369}$ Sobre os métodos de estudo dos textos gregos, cf. Kristeller, El pensamiento renascentista e sus fuentes, pg. 121.

${ }^{370}$ Kristeller, El pensamiento renascentista e sus fuentes, p. 120
} 
características próprias de uma Itália mais modesta e retardatária em relação à rica civilização medieval francesa $^{371}$, por seus vínculos estreitos à cultura romana e sua proximidade com o Império Bizantino. O movimento humanista seria resultado de um amálgama entre o interesse tardio pelo estudo dos clássicos (sob influência da França e do oriente) e as tradições medievais italianas.

Entretanto, na ânsia por amenizar a leitura de alguns intérpretes do Renascimento que opunha radicalmente o humanismo, como representante do novo, à velha escolástica, Kristeller coloca o movimento humanista num campo a parte: os humanistas não seriam cientistas nem filósofos, mas gramáticos e retóricos. Os debates entre os diferentes ramos são compreendidos como uma "batalha das artes e não como uma luta pela sobrevivência"372.

Antes de passarmos ao exame da concepção elaborada por Baron, pode ser interessante examinarmos a crítica de Eugênio Garin a Kristeller. Com efeito, Garin toma uma direção um pouco diferente. Para ele, os humanistas "não podem ser reduzidos a simples "gramáticos" ${ }^{373}$ que disponibilizaram um amplo rol de textos clássicos dos quais teriam se beneficiado a filosofia e a ciência que viriam depois deles. Mais do que isso, com os métodos humanistas operou-se uma mudança de concepção, uma nova atitude intelectual, que se configurou antes como um desvio do que como continuidade linear com o passado escolástico. Desta forma, Garin, diferente de

\footnotetext{
371 "Não há dúvida de que a França foi o centro da civilização medieval e que os demais países da Europa ocidental seguiram sua liderança, desde o período carolíngeo até o início do século XIV. Desde o início a Itália não foi uma exceção a essa regra; porém se os outros países - e em especial a Inglaterra, a Alemanha e os Países Baixos - participaram ativamente nas principais explorações culturais do período e seguiram um mesmo desenvolvimento geral, a Itália ocupou uma posição um tanto peculiar. Antes do século XII, sua participação ativa em muitos aspectos importantes da cultura medieval estava muito atrasada em comparação com a de outros países". Kristeller, El pensamiento renascentista e sus fuentes, p. 117

${ }^{372}$ Kristeller, El pensamiento renascentista e sus fuentes, pg. 147.

${ }^{373}$ Garin, Ciência e vida civil no Renascimento italiano, 1996, pg. 8.
} 
Kristeller, põe em evidência a descontinuidade que esta mudança de perspectiva representou e que terminou por produzir um novo quadro.

Esta complexa mudança cultural, contudo, não aconteceu nem sob um único signo nem por meio de esquemas rígidos ou por continuidade linear, em setores nitidamente separados. Foi, antes, uma ruptura de equilíbrio e de esquemas, que torna evidente a insuficiência de uma historiografia classificatória que tende a separar as diversas disciplinas, fundamentando-as em pseudocategorias: lá as cartas, aqui a filosofia e as ciências, ali a arte e a moral, aqui a religião e a política. Perde-se, assim, o sentido das mutáveis hegemonias das várias formas de atividade humana; ignora-se o fato de que as atitudes fundamentais e os quadros de conjunto, que têm um peso decisivo para o progresso da cultura, encontram vez por outra o seu centro de gravidade no âmbito daquela "forma" que acaba por predominar, atingindo o máximo de caracterização e perfeição. ${ }^{374}$

Garin então procura o significado desta ruptura de equilíbrio no nexo entre a atividade pública do humanista, a sua produção epistolar e filosófica e a dinâmica dos embates políticos da sociedade italiana. Há uma diferença abissal entre a produção epistolar de um dettatore na Florença da virada do século XIV para o XV e a de um dettatore na Florença sob os Médici. Aparentemente, ambos são notários que passam o dia a escrever cartas lançando mão da retórica, mas enquanto o chanceler Coluccio Salutati era a figura de proa da república, desempenhando um papel fundamental na elaboração da "imagem de Florença como herdeira da antiga Roma republicana, baluarte da liberdade para todos os povos itálicos", Giovanni Scala era um mero funcionário sob ordens, a quem não mais cabia a iniciativa e a arquitetura da política.

Os estudos de Hans Baron sobre o humanismo e a interpretação de Garin apresentam uma interessante convergência. Baron busca na Itália do Quattrocento os elementos que atuaram para "remodelar a influência da antiguidade" até que esta influência se tornasse mais do que um mero gosto por coisas antigas. No caso do assim chamado "humanismo cívico", as ameaças de Gian Galeazzo Visconti (e, depois, de seu

\footnotetext{
${ }^{374}$ Garin, Ciência e vida civil no Renascimento italiano, pgs. 10-11
} 
filho Filippo) contra a cidade de Florença teriam sido decisivas para a elaboração de uma defesa original da liberdade. Embora o ano de 1402 tenha seja o momento em que a situação se precipita, Baron considera que:

A partir de 1350, os Visconti de Milão tornaram-se os aspirantes finais a um Estado regional norte-italiano; e mesmo a uma monarquia que unificaria as porções norte e central da Itália. Durante a vida do grande arcebispo Giovanni Visconti, amigo e patrono de Petrarca, Florença passou por um período no qual sua política externa esteve concentrada em fazer frente ao perigo de uma monarquia milanesa, que ameaçava engolfar a independência das cidades-estado e regiões ${ }^{375}$.

Quentin Skinner, retomando a leitura de Kristeller, discorda de Baron nos seguintes termos:

Há, porém, dois fatores - ambos centrais numa leitura do humanismo renascentista que nos obrigam a questionar a exposição de Baron. O primeiro é que, tratando a crise de 1402 como "um catalisador que fez emergir novas idéias", Baron ignorou em que medida tais idéias não eram novas em absoluto, mas, antes, um legado das cidadesrepúblicas da Itália medieval (cf. Baron, 1966, p. 446). O outro problema é que, enfatizando as qualidades específicas do humanismo "cívico", Baron também deixou de considerar a natureza dos elos que havia entre os escritores florentinos de inícios do Quatrocentos e o movimento, mais amplo, do humanismo petrarquiano, que já se desenvolvera no correr do século XIV. ${ }^{376}$

Entretanto, segundo Baron, algo fundamental havia se modificado. Até meados do Trezentos, a verdadeira natureza da questão não podia ser inteiramente discernida. As disputas entre os poderes locais na península eram compreendidas nos termos do embate entre guelfos e gibelinos, como parte das contenções entre o Império e o Papado. Deste modo, os Visconti ainda eram vistos como líderes dos gibelinos, portanto, como aliados do Império ${ }^{377}$. Assim, quando da ocupação da Bolonha por parte dos milaneses, a justificativa de Florença para apoiar a cidade-estado então ocupada se

\footnotetext{
${ }^{375}$ Baron, the crisis of early Italian Renaissance, pg. 13

${ }^{376}$ Skinner, As fundações do pensamento político moderno, p. 93

${ }^{377}$ Baron, The crisis of early Italian Renaissance, pg. 14
} 
deu ainda em termos de obrigação para com a Igreja, como suserana da Bolonha e das cidades guelfas. A liberdade era então compreendida como intrinsecamente ligada à luta dos guelfos, identificados à causa da Igreja, contra os tiranos, prepostos do imperador.

$\mathrm{Na}$ seguinte definição de "guelfismo" por Matteo Villani, o cronista florentino contemporâneo dos acontecimentos de 1350 e 1360, o que impressiona é que não haja nenhuma referência à disputa simultânea entre o monarquismo da Milão gibelina e a liberdade cívica da Florença guelfa. Os guelfos, escreve Matteo, usando uma fórmula valorizada na época, são aqueles "que seguem a Santa Igreja nos assuntos do mundo", enquanto que os gibelinos são aqueles "que seguem o Império sendo este o lado dos verdadeiros crentes ou não". ${ }^{378}$

Em 1420, portanto quase cem anos depois, os termos do discurso são equacionados de outra maneira e a defesa da liberdade já aparece separada da Igreja. Esta mudança se expressa no modo como Leonardo Bruni redefine a questão, por ocasião da revisão do estatuto do partido guelfo florentino:

Se você considerar a comunidade dos guelfos do ponto de vista religioso, então a encontrará conectada com a Igreja Romana; se considerá-la do ponto de vista humano, então a encontrará conectada à liberdade - liberdade sem a qual nenhuma república pode existir, e sem a qual, segundo os homens mais sábios, não se deveria viver ${ }^{379}$.

É esta mudança de discurso ocorrida neste ínterim que Baron se propõe a explicar, polemizando com as concepções anteriores que entendiam esta mudança como uma mera contraposição a Dante ${ }^{380}$. Baron recupera o sentido político do discurso no contexto das urgências da vita activa. Assim, em meios aos esforços de Florença para se manter independente é que uma nova elaboração de libertas teve lugar ali. Somente quando a concepção do guelfismo como partido da Igreja Católica foi perdendo fôlego, na medida em que a possibilidade real de retorno do Papa à Roma (o que acabou

\footnotetext{
${ }^{378}$ Baron, The crisis of early Italian Renaissance, pg. 14

${ }^{379}$ Baron, The crisis of early Italian Renaissance, pg. 15

${ }^{380}$ Baron, The crisis of early Italian Renaissance, pg. 459.
} 
ocorrendo em 1377) passava a significar uma ameaça à autonomia das cidades; quando os esforços diplomáticos para conter a política expansionista de Gian Galezzo Visconti fracassaram e Florença passa a discernir os verdadeiros objetivos deste último, é só então que se reúnem as condições para se pensar a política a partir de um outro enquadramento.

Hanan Yoran, apesar de reconhecer certas dificuldades nesta leitura do humanismo, ao mesmo tempo chama atenção para um aspecto importante da interpretação de Baron. Segundo ele, Baron tem o mérito de demonstrar o contraste entre o humanismo de Petrarca (o qual fetichizaria ${ }^{381}$ a herança clássica, ficando preso à imitação) e o humanismo cívico, cujo emprego de "noções clássicas, textos, e gêneros como instrumentos para confrontar questões e problemas endêmicos da sua própria sociedade" ${ }^{382}$ tornou a imitação humanista da literatura clássica critica e criativa.

Assim, a oposição entre vita contemplativa e vita activa, tradicionalmente adotada na Idade Média, e na qual a primeira era vista como superior em relação à segunda, foi questionada pelo humanismo cívico. Ainda seguindo a trilha de Baron, Yoran afirma que esta mudança de atitude com relação ao vivere civile apareceria não somente no interesse por temas mais mundanos como a família e a economia (vistos como condição de realização da "humanidade do homem"383), mas também na forma de abordar a história, que não mais apareceria como subordinada a categorias transcendentes e a um ordenamento metafísico estático. Na História do Povo Florentino de Leonardo Bruni ${ }^{384}$, por exemplo, haveria uma tendência a representar o passado por

\footnotetext{
${ }^{381}$ O termo é de Yoran.

${ }^{382}$ Yoran, Between utopia and dystopia, 22.

${ }^{383}$ Exemplos disso seriam a tradução de Leonardo Bruni dOs Econômicos de Aristóteles e a obra o Della Famiglia escrita por Leon Batista Alberti. Cf. YORAN, H. Between utopia and dystopia pg. 22

${ }^{384}$ Leonardo Bruni's path-breaking History of the Florentine People demonstrates a critical sensibility as it demolishes the fabulous medieval historical tales and realistically evaluates historical events.
} 
categorias seculares e pragmáticas, o que permite a Baron afirmar que os humanistas inventaram a história moderna e a noção de distância histórica, fazendo emergir o conceito de anacronismo.

No contexto das discussões mais recentes, essas diferenças de concepção entre Kristeller, Garin e Baron se multiplicam em uma miríade de polêmicas, abordagens, debates e propostas. Especificamente, no que se refere ao humanismo na Inglaterra, como nota Jonathan Woolfson, “apesar da grande quantidade de trabalhos neste campo, a historiografia oferece pouco consenso a respeito da natureza do humanismo Tudor"385. $\mathrm{Na}$ esteira da interpretação de Kristeller, Alistair Fox sustentou no seu importante ensaio publicado em 1986, "Facts and Fallacies: Interpreting English Humanism", que o humanismo Tudor não constituía um movimento coerente, pois as diferenças entre os humanistas do período seriam mais importantes que as similaridades, e o único ponto efetivamente comum estaria na valorização dos estudos clássicos. Apesar disso, estudos acadêmicos modernos tenderam a minimizar estas diferenças, procurando oferecer uma visão coerente e harmoniosa, mas acabaram por apresentar "um retrato do humanismo inglês borrado em seus contornos", tornando-se, por fim, distorcido e confuso para quem o observa. A causa de alguns destes enganos, afirma Fox, seria "uma confiança excessiva e, às vezes, exclusiva em evidências extrínsecas mais do que intrínsecas"386. O resultado é que homens como Stephen Hawes, John Skelton e Alexander Barclay são postos no mesmo quadro em que figura também Thomas Linacre, por exemplo, unicamente em virtude de algumas características comuns. Emblemática seria a figura de Skelton, que, embora aparentasse ser um humanista exemplar (laureado pelas universidades de Cambridge e Oxford, obtendo o mais alto grau em retórica, tradutor da

\footnotetext{
${ }^{385}$ Woolfson, Reassessing Tudor Humanism, pg. 3.

${ }^{386}$ Fox, Alistair e Guy, John, Reassessing the Henrician Age: Humanism, Politics and Reform 1500-1550, pgs. 10-11.
} 
Biblioteca histórica de Diodorus Siculos e ainda tutor do jovem príncipe Henrique), foi um dos mais ferrenhos opositores das mudanças curriculares propostas pelos humanistas. "Em Speke Parott, seu ataque virulento a Wolsey, escrito em 1520, Skelton denunciou a instituição de cursos em grego em Oxford e Cambridge, o novo método humanista de ensinar latim nas escolas de gramática, e ainda a preocupação geral dos humanistas com a eloquência. (...). Na guerra entre 'gregos' e 'troianos', Skelton escolheu o lado oposto àquele dos verdadeiros humanistas, tais como Thomas More". ${ }^{387}$ Pretensões humanistas e erudição, mas sem comprometimento com objetivos humanistas e sobretudo sem um ethos humanista que o anime, conclui Fox, não bastam para tornar alguém um verdadeiro humanista.

Entretanto, Fox na sua busca por distinções nunca esclarece o que seria este ethos humanista e, ao longo do ensaio, ora determinadas figuras (tais como Colet, More e Erasmo) são aproximadas, sendo identificadas conjuntamente como humanistas, ora esta aproximação é relativizada. Assim, Colet era essencialmente um teólogo ${ }^{388}$, enquanto que More se afastou progressivamente de Erasmo conforme foi se aproximando da vida ativa e, no final, após 20 anos de carreira pública, nem mesmo seria possível contá-lo entre os humanistas ${ }^{389}$. Por fim, as diferenças entre eles impossibilitaria englobá-los num conjunto.

\footnotetext{
${ }^{387}$ Fox, Alistair \& Guy, John, Reassessing the Henrician Age: Humanism, Politics and Reform 15001550, pgs. 13-14.

388 "Colet era essencialmente um teólogo que se tornou um humanista porque achou a doutrina neoplatônica dos humanistas florentinos compatível com o seu cristianismo, e úteis os métodos exegéticos humanistas para a elucidação do significado da escritura. (...) Ele certamente não tinha nenhuma visão detalhada e abrangente de reforma política de amplo espectro como aquela enunciada por Erasmo." Fox \& Guy, Reassessing the Henrician Age: Humanism, Politics and Reform 1500-1550, pg. 22.

389 "Pelo menos desde 1516, More tinha desenvolvido dúvidas fundamentais sobre aspectos do programa erasmiano, a despeito da sua amizade por Erasmo e da sua vigorosa defesa da Moria e do Novo Testamento. (...) A decisão de More de entrar para o serviço do rei em 1517 (possivelmente antes), e sua relutância em informar Erasmo, sugere que ele tinha assumido um papel que ele sabia que incorreria na desaprovação de seu amigo (...). No fim da vida, ao dizer que queria queimar não somente os primeiros
} 
Uma vez que as diferenças entre Colet, More e Erasmo tenham sido apropriadamente reconhecidas, é difícil vê-los formando qualquer "movimento" (...). Esta impressão pode somente ser criada pelo amálgama de características distintivas de cada humanista separado em um compósito homogêneo, o qual é então tomado para representá-los ${ }^{390}$.

Mais do que negar que existam humanistas com ideias eventualmente compartilhadas na Inglaterra do século XVI, o propósito de Fox é pôr em questão a existência de um movimento humanista inglês, mais precisamente um movimento humanista erasmiano, com todas as consequências decorrentes disso.

Além de uma confiança excessiva em evidências extrínsecas, a confusão nasce também de tentativas de fazer amplas generalizações sobre o humanismo como um movimento. Ele foi caracterizado variadamente como neo-estóico, dependendo da crença "de que todos os homens formam uma única sociedade, a qual é, ou deveria ser, governada por uma Lei Natural"; como platônico, sustentando o ideal de "um estado justo e bom que é governado por uma elite de guardiões e filósofos"; e como prático, utilitário e realisticamente pragmático. Qualquer que seja a doutrina social imputada aos humanistas, ela é quase invariavelmente descrita como "erasmiana"391.

Ora, se não houve um movimento humanista erasmiano na Inglaterra (ou mesmo qualquer movimento humanista), as transformações ocorridas no período Tudor podem ser legitimamente atribuídas a homens de espírito prático como o advogado Christopher de St. German e Thomas Cromwell. No fim, os únicos a quem Fox concede o epíteto de erasmianos são o próprio Erasmo e Thomas Elyot, para infortúnio de ambos. Para que se compreenda melhor o ponto de vista a partir do qual Alistair Fox aborda a questão, vale apresentar ainda a comparação que ele faz entre Thomas Elyot e Thomas Starkey.

livros de Erasmo, mas também o seu próprio, More revela que ele tinha detido seu próprio humanismo muito antes que alguém o fizesse por ele. Então, por volta de 1533, More tinha pouco em comum com Erasmo que pudesse ser atribuído a um mútuo comprometimento com o humanismo." Fox, Alistair \& Guy, John, Reassessing the Henrician Age: Humanism, Politics and Reform 1500-1550, 19-21.

${ }^{390}$ Fox \& Guy, Reassessing the Henrician Age: Humanism, Politics and Reform 1500-1550, pg. 22.

${ }^{391}$ Fox \& Guy, Reassessing the Henrician Age: Humanism, Politics and Reform 1500-1550, pg. 18. 
Um exame cuidadoso dos trabalhos de Elyot e Starkey mostra (...) que duas abordagens diametralmente opostas do problema do governo que têm sido artificialmente aproximadas. É somente Elyot, não Starkey, que se apoia em fontes clássicas. De fato, Starkey, a certa altura, rejeita especificamente a república ideal de Platão como modelo por conta de sua impraticabilidade; ele é mais influenciado pelo exemplo das várias cidades-estado italianas do que pela antiguidade clássica. Elyot se contenta em desfilar preceitos e exemplos clássicos com incansável otimismo; Starkey prefere trabalhar racional e empiricamente, usando as descobertas da experiência e do senso comum. É só Elyot que é erasmiano; a teoria política de Starkey pode não ter derivado de qualquer treinamento humanista. ${ }^{392}$

Fox estabelece um divórcio e até mesmo uma oposição entre a política prática e a filosofia e afasta a ideia de que tenha havido um movimento humanista erasmiano influente na política Inglesa ${ }^{393}$. Daí a necessidade de problematizar a existência de um movimento, e mesmo de humanistas, e evidenciar os indivíduos que diferem sobremaneira uns dos outros. Segundo esta interpretação, para que pudesse efetivamente ter uma carreira, More teve que deixar de lado a sua proximidade com as ideias de Erasmo. Se para Gombrich não existe arte, apenas artistas, para Alistair Fox não existiu um humanismo erasmiano ou um humanismo do norte, apenas humanistas.

Woolfson aponta, entretanto, que muitos estudiosos do humanismo do período Tudor continuam a atribuir ao movimento um conteúdo ideológico ou filosófico ${ }^{394}$. Segundo ele, haveria três razões para isso: em primeiro lugar, embora os studia humanitatis possam ser vistos como apenas um conjunto particular de disciplinas, considerava-se que eles forneciam a formação necessária à atividade na vida pública, o que necessariamente pressupõe certas concepções sobre formação e sobre vida pública; em segundo lugar, "se o humanismo como uma ferramenta conceitual do historiador for

\footnotetext{
${ }^{392}$ Fox \& Guy, Reassessing the Henrician Age: Humanism, Politics and Reform 1500-1550, pgs. 24-25.

${ }^{393} \mathrm{O}$ alvo da crítica de Fox é sobretudo a obra English Humanists and Reformation Politics de James Kelsey McCônica, que sustenta ter havido uma presença importante de humanistas erasmianos na corte de Henrique VIII.

${ }^{394}$ Woolfson, Reassessing Tudor Humanism, pg. 3.
} 
esvaziado de significado ideológico e filosófico, corre o risco de ser reduzido a uma moda cultural, cujo apelo é historicamente inexplicável e cujo significado é historicamente imensurável"; em terceiro lugar, os estudiosos do período Tudor, identificaram o humanismo com atividades menos acadêmicas e mais públicas e ativas, o que o caracterizaria, portanto, como "mais instrumental e pragmático". E Woolfson completa: considerando que, se nestes termos, o humanismo "não é inerentemente ideológico em si mesmo, é pelo menos a ferramenta essencial de outros propósitos ideológicos $\$ 395$.

Alguns autores, apesar da diversidade ideológica que caracterizou humanismo, buscaram alguns traços distintivos do período Tudor e julgaram encontrar um "limiar da modernidade". Assim, Arthur Kinney, em seu Humanist Poetics: Thought, Rhetoric, and Fiction in Sixteenth-century England, afirma que a consciência de que se descortinava um mundo novo, presente, por exemplo, na expressão de Erasmo: "Que mundo vejo despontar: por que não posso voltar a ser jovem novamente?"396, era algo próprio do espírito dos humanistas da Renascença e aparecia como auto-evidente. Este espírito, segundo ele, era consequência da descoberta dos textos gregos, que "liberou os homens do seu estudo concentrado dos Pais da Igreja, da contemplação e da vida após a morte, conduzindo-os com estimulante frescor a um novo senso de liberdade pessoal e realização" 397 . Na Inglaterra dos Tudor, este "impulso fundamental dos florentinos e dos humanistas do norte", que deitava suas raízes em fontes clássicas muito variadas, teria

\footnotetext{
${ }^{395}$ Woolfson, Reassessing Tudor Humanism, pg. 4.

${ }^{396}$ Carta de Erasmo a Wolfgang Capito de 26 February 1517. Cf. Kinney, Humanist Poetics: Thought, Rhetoric, and Fiction in Sixteenth-century England, pg. 3.

${ }^{397}$ Kinney, Humanist Poetics: Thought, Rhetoric, and Fiction in Sixteenth-century England, pg. 3.
} 
se transformado em uma glorificação mais ampla do homem. Segundo ele, isto se deveria principalmente a uma leitura de Platão (mais presente no humanismo tardio) ${ }^{398}$ que enfatiza as potencialidades do homem, e à influência de Marsílio Ficino em figuras de relevo como John Colet e William Grocyn. Kinney lembra ainda que John Colet inclusive se correspondia com Ficino, que Thomas More traduziu a biografia de Pico della Mirandola e que "é Pico quem leva adiante as ideias de Ficino em uma memorável fábula que deve ter permanecido nas mentes de muitos da primeira geração de humanistas ingleses”399. Entretanto, Kinney não reduz o humanismo Tudor às filosofias de Ficino e Platão, pois considera que a releitura aristotélica de Ficino realizada por Pomponazzi também cumpriu um papel importante. Partindo de uma consideração mais próxima do neoplatonismo, segundo a qual a natureza do homem é fundamentalmente ambígua na medida em que está colocada entre as criaturas mortais e as imortais, entre a temporalidade e a eternidade, Pomponazzi, em seu Tractatus de immortalitate animae, discordava, porém, dos platônicos. Estes últimos sustentavam que, sendo a realidade espiritual superior, o objetivo central da vida humana consistia na ascensão à contemplação; Pomponazzi, entretanto, apontava que este objetivo só seria atingível na vida futura e que, por isso, o homem deveria se concentrar em sua vida mortal e nas virtudes terrenas. Assim, a ideia da dignidade do homem era mantida, mas sua existência terrena acabava sendo investida de um valor intrínseco maior.

\footnotetext{
${ }^{398}$ A fim de corroborar a sua afirmação, Kinney recorre a Kristeller nos seguintes termos: "Paul Oskar Kristeller escreveu recentemente que não podemos escapar à impressão de que após o início do humanismo renascentista, a ênfase no homem e na sua dignidade se tornou mais persistente, mais exclusiva, e ultimamente mais sistemática que jamais tinha sido durante os séculos precedentes e mesmo durante a antiguidade clássica". Kinney, Humanist Poetics: Thought, Rhetoric, and Fiction in Sixteenthcentury England, pg. 4.

${ }^{399}$ Kinney, Humanist Poetics: Thought, Rhetoric, and Fiction in Sixteenth-century England, pg. 4. A fábula a que Kinney se refere é primeira parte do Discurso sobre a dignidade do homem.
} 
De qualquer forma, este conjunto de concepções, em que se relacionavam elementos e temas de Platão, Aristóteles e Cícero, entre outros autores, teria constituído, para Kinney, o início do humanismo do período Tudor. Através delas

os humanistas Tudor chegaram a uma crescente certeza de que podiam moldar e remoldar a si próprios, e também moldar e remoldar a sociedade. Sendo educável, o homem poderia também ser perfectível. Esta é a ideia singular e dominante que na Inglaterra obteve fortalecimento e realização nas mãos de professores e escritores, principalmente, se não unicamente, em seu desenvolvimento, uso e defesa da retórica ${ }^{400}$.

De fato esta noção de automodelação (self-fashioning) foi tão importante no humanismo inglês deste período que mereceu especial atenção no estudo realizado por Stephen Greenblatt na sua obra Renaissance Self-fashioning: from More to Shakespeare, publicada em 1980. Greenblatt parte da consideração um tanto óbvia, segundo ele, de que havia na Inglaterra do século XVI um "eu" e um "senso de que ele poderia ser moldável". Levando em conta que de algum modo sempre há um “eu” (self) ("um senso de ordem pessoal, um modo característico de se dirigir ao mundo, uma estrutura de desejos vinculados") e "elementos de moldagem deliberada na formação e expressão da identidade", o que Greenblatt afirma ter em vista é antes "a percepção tão antiga quanto os escritos acadêmicos de Burckhardt e Michelet - de que há, no início do período moderno, uma mudança nas estruturas estéticas, intelectuais, psicológicas e sociais que governam a geração das identidades"401. Esta transformação se expressa no fato de que, enquanto em Chaucer não há nenhuma menção à palavra fashion, nos autores ingleses do séc. XVI ela passa a ser de uso recorrente no sentido de formação do "eu" (self). À primeira vista este pode parecer um detalhe lateral, mas trata-se de uma mudança significativa que possibilitou, por exemplo, que o Arcebispo

\footnotetext{
${ }^{400}$ Kinney, Humanist Poetics: Thought, Rhetoric, and Fiction in Sixteenth-century England, p. 5.

${ }^{401}$ Greenblatt, Renaissance Self-fashioning: from More to Shakespeare, p. 1.
} 
Sandys afirmasse em um sermão que "somos exortados a nos moldarmos [fashion ourselves] de acordo com aquela similitude e aparência que está Nele» ${ }^{\wedge 02}$, uma visada essencialmente distinta da máxima agostiniana "tente construir a si mesmo, e edificará a ruína”.

Na leitura que faz da famosa pintura Os Embaixadores de Holbein, Greenblatt mostra também o caráter, ao mesmo tempo, teatral que há nesta autoconstrução. A despeito da pompa e dos instrumentos que representam o quadrivium, colocados entre os dois embaixadores, os quais por sua vez encarnam o trivium, a sombra ameaçadora da natureza irrompe no meio do cenário. Exceto por esta sombra, de fato invisível a primeira vista e que só se revela ao expectador de viés, não há qualquer sinal da natureza no quadro. Das pesadas cortinas que escondem o exterior até as vestimentas, passando pelos artefatos, tudo é artifício para o palco da política e dos tribunais ${ }^{403}$.

O ambicioso programa de educação humanista que forja o self do vir bonum, ao mesmo tempo que critica, também prepara para este palco. "Todos eles [os humanistas] compartilhavam a convicção de que a educação apropriada poderia levar a um Estado ideal para o qual a Atenas de Péricles e, mais importante para os Tudor, a Roma de Augusto funcionavam como precedentes garantidores". ${ }^{404}$ Desta forma, a educação apropriada era aquela que, pela imitação dos antigos, alcançava a realização da razão pela palavra. Mas, este raciocínio em solo inglês vinha acompanhado de outro (se no princípio era o verbo, então o homem eloquente realiza a graça de Deus) presente no prefácio da Arte of Rhetorique de Thomas Wilson, feita a partir do De Oratore de Cícero $^{405}$.

\footnotetext{
${ }^{402}$ Greenblatt, Renaissance Self-fashioning: from More to Shakespeare, p. 3.

${ }^{403}$ Greenblatt, Renaissance Self-fashioning: from More to Shakespeare, pgs. 17- 23.

${ }^{404}$ Kinney, Humanist Poetics: Thought, Rhetoric, and Fiction in Sixteenth-century England , p. 5

${ }^{405}$ Kinney, Humanist Poetics: Thought, Rhetoric, and Fiction in Sixteenth-century England , p. 7-8
} 
A conjunção de ideia, linguagem e atitudes ajuda ainda a clarificar o currículo de uma escola humanista exemplar tal como a de St. Paul, a qual combinava um curso radicalmente novo de estudos baseado em antigos textos gregos e latinos e uma ênfase na retórica com uma cerimônia religiosa mais tradicional em seu entorno: a imagem de Cristo na sala de aula, as orações matinais para os meninos de comprovada capacidade intelectual, as lições piedosas acrescentadas pelo mestre-escola William Lily ao final das lições de declinação.

Reforçados por descobertas recentes de textos-chave romanos (...), os humanistas Tudor formularam um plano de lições centrado no trivium da ars disserendi, ou arte de falar corretamente, falar bem e argumentar bem. Juntos, tais estudos verbais levariam os homens à perfeição individual, enquanto também os treinavam para serem cidadãos ideais, raciocinando pela pisteis (modos de persuasão) aristotélica ${ }^{406}$.

O cumprimento do currículo escolar humanista exigia pelo menos de oito a dez horas ao dia, seis dias por semana. Esta automoldagem não pode, porém, ser confundida com autonomia, já que a família, o Estado e as instituições religiosas impunham uma rígida disciplina ${ }^{407}$. Segundo Greenblatt, esta ausência de autonomia efetiva está presente nas considerações que More faz no Diálogo do conforto contra a tribulação a respeito de sua vida pregressa e do caráter farsesco, teatral de que se dotava boa parte da convivência entre as pessoas, de modo que esta muitas vezes nada mais era que uma comédia social. Greenblatt nota nestes escritos uma profunda consciência da possibilidade de, neste contexto, se aperfeiçoar na atuação teatral (bem como do caráter irreal e performático da peça) e, ao mesmo tempo, do poder que esta mesma comédia tem de se impor para quem dela participa. A este respeito ele destaca a versão ficcionalizada, que ali se encontra, de um jantar na casa do cardeal Wolsey testemunhado por More. O cardeal, após ter proferido uma esplêndida oração, e tendo ficado muito orgulhoso com seu próprio desempenho, não consegue resistir à sua

\footnotetext{
${ }^{406}$ Kinney, Humanist Poetics: Thought, Rhetoric, and Fiction in Sixteenth-century England , p. 8-9

${ }^{407}$ Como aponta Woolfson, por conta disso Anthony Grafton e Lisa Jardine, em seu livro From Humanism to the Humanities, criticam a pedagogia humanista, mostrando a distância entre o ideal e prática que, ao invés de produzir um indivíduo autônomo, resulta no seu esmagamento e numa atitude de submissão à autoridade. Cf. Woolfson, Reassessing Tudor Humanism, pg. 6.
} 
ansiedade por elogios e acaba por pedir aos convivas que se manifestem. O jovem e ambicioso More, ciente de sua capacidade oratória, apressa-se em fazer um discurso elogioso impecável e se enche de orgulho, tanto mais porque seria seguido por um padre ignorante. O padre, porém, era "uma velha raposa" e não deixa por menos, elogiando hábil e profusamente o cardeal. Mas eles foram ultrapassados de longe pelo último conviva que, sem ter mais o que dizer, ergue as mãos pro céu, encantado pela eloquência do cardeal, solta um profundo suspiro e chora. Esta espécie de "arte" da adulação provocava em More um misto de curiosidade, estranheza e mal-estar. "O espetáculo ao mesmo tempo o repelia e o fascinava. Ele jamais poderia renunciar ao mundo numa santa indignação. Ao contrário, ele se tornou um bem sucedido performer ${ }^{\text {"408 }}$. Como que seguindo um script, o sucesso mesmo da sua performance o conduziu à ruína, pois na medida mesma em que permitiu sua ascensão ao mais alto cargo do reino, acabou por enredá-lo em uma trama em que os próprios aspectos da sociabilidade que via como grotescos e repulsivos se impuseram a ele. ${ }^{409}$

Se a possibilidade de se automodelar se dava em geral dentro de limites mundanos bem definidos, que muitas vezes lhe conferiam um caráter farsesco ${ }^{410}$, estes mesmos limites estavam presentes na própria maneira de se conceber o "self". No capítulo de seu estudo sobre o teatro elisabetano intitulado "Subjetividade e processo

\footnotetext{
${ }^{408}$ Greenblatt, Renaissance Self-fashioning: from More to Shakespeare, pgs. 11- 12.

409 "Em maio de 1532, tentando se salvar, More renunciou à chancelaria sob o pretexto de estar com problemas de saúde, mas ele era muito importante e muito visível para obter o privilégio de uma aposentadoria silenciosa e pacífica. A recusa em subscrever o Juramento de Supremacia - isto é, reconhecer que o rei era o chefe supremo da Igreja na Inglaterra - levou-o à torre em 1534, e ao cadafalso em 6 julho de 1535" (Greenblatt, Renaissance Self-fashioning: from More to Shakespeare, pg. 12).

${ }^{410}$ No âmbito de nossa discussão é importante não deixar de notar que More não reduz a sociedade a este aspecto, no qual a mentira, a adulação e as ilusões trabalham a serviço do orgulho, da mesquinharia e da ambição. Como veremos, este era um aspecto crucial do contexto em que os humanistas tentavam levar adiante seu projeto. E este último tinha em vista um aspecto oposto, como aponta Greenblatt ao destacar o significado do ambiente em que se passa a anedota relatada por More: "O cenário lembra o rico significado do jantar para More, emblema da sociedade humana tanto em sua vaidade tola quanto em seus preciosos momentos de comunicação" (Greenblatt, Renaissance Self-fashioning: from More to Shakespeare, pg. 12).
} 
social" Jonathan Dollimore afirma que encarar a subjetividade a partir de um "humanismo essencialista"411 para o período que antecede o Iluminismo é incorrer em anacronismo $^{412}$. Segundo ele, a noção de "indivíduo como entidade substancial” surgirá apenas na passagem do séc. XVII para o XVIII. Neste período, a concepção de homem estava num momento de transição entre as formulações metafísico-cristã e as seculares. “O paradigma do essencialismo cristão apresentava a alma como metafisicamente derivativa e nesta medida não permitia a ideia de um sujeito autogerador, unificado e autônomo postulada pelo humanismo essencialista" ${ }^{413}$. Neste sentido, se se pode falar em "self", é de uma maneira que não implique em confundi-lo com a ideia de um indivíduo unificado e autônomo.

O mesmo impulso de moldagem do "self" presente no discurso destes humanistas também se verifica na promoção de um projeto que visava certa reforma social. Polemizando com a tese de Oskar Kristeller, que nega qualquer conteúdo específico ao humanismo, e definindo este último como o cultivo da bonae litterae e da studia humanitatis, Brendan Bradshaw argumenta que, apesar das diferenças entre os humanistas, é possível sustentar que o humanismo do norte é mais do que um modo de falar ou um conjunto de habilidades extrínsecas a qualquer conteúdo substancial ${ }^{414}$. Diferente do que poderia parecer à primeira vista, os humanistas desenvolveram um

\footnotetext{
411 O que o autor nomeia de "humanismo essencialista" nada tem a ver com o humanismo renascentista que estamos tratando, mas de uma concepção contemporânea que compreende o homem como um indivíduo e projeta uma essência humana para períodos históricos precedentes.

${ }^{412}$ Dollimore, Radical Tragedy, pg. 153

${ }^{413}$ Dollimore, Radical Tragedy, pg. 155-156

${ }^{414}$ Bradshaw, Transalpine Humanism. In: Burns, J. H. The Cambridge History of Political Thought, pgs. 95-97
} 
discurso político que aliou rigor filosófico e eloquência; isso se deu por meio do recurso a "uma abordagem literária-ficcional na qual uma forma literária - diálogo, narrativa fictícia, alegoria, sátira - foi explorada como veículo para o discurso filosófico sustentado" $" 415$, procedimento cujo exemplo mais "brilhantemente duradouro", aos olhos de Bradshaw, seria constituído pela Utopia.

Porém, mais do que o humanismo Tudor, Bradshaw busca caracterizar o humanismo do norte (ou transalpino, como ele o chama) como um movimento específico. Desta forma, sua análise inclui autores como More, Erasmo, Budé, Dudley, Elyot e Seyssel. E o primeiro traço em comum que ele extrai do exame das obras é seu caráter progressista. A Utopia de More seria composta por uma crítica à sociedade cavalheiresca medieval, no Livro I, seguida do retrato de uma sociedade ideal, inspirada na República de Platão, no Livro II. No Elogio da Loucura, Erasmo estaria contrastando a sabedoria, representada pela herança clássica, à loucura das práticas contemporâneas. E mesmo para os humanistas conservadores do período, afirma Bradshaw, é possível divisar o mesmo impulso progressista "na forma do axioma paradoxal" de mudar para que tudo permaneça como está. Tal seria o caso, por exemplo, de La Monarchie de France de Claude de Seyssel, que “escreve com espírito piedoso para seu patrono Francisco I e exalta a monarquia francesa como estando de acordo com a forma ideal da República»"416.

Para compreender como este impulso progressista assume a forma de um pensamento político próprio, Bradshaw toma em consideração duas obras aparentemente distintas: a Utopia de More e o Da formação de um príncipe cristão de

\footnotetext{
${ }^{415}$ Bradshaw, Transalpine Humanism. In: Burns, J. H. The Cambridge History of Political Thought, pg. 98

${ }^{416}$ Bradshaw, "Transalpine Humanism". In: Burns, J. H. The Cambridge History of Political Thought, pg. 96
} 
Erasmo, a primeira preocupada com os processos do governo e a segunda com a pessoa do governante. Bradshaw procura mostrar que, apesar das diferenças, ambas convergiriam a respeito do significado do governo com relação a seus fins: para a realização da república, seria necessário "reformar a ordem social como um todo".

A chave da compreensão residiria, então no fim que as obras têm em vista. E este fim seria justamente a realização da república cristã. Deste ponto de vista, a originalidade do humanismo do norte estaria numa síntese das noções clássicas de república, sabedoria e vir humanus, respectivamente com as de comunidade cristã, de sabedoria cristã e de homem como Imago Dei. Esta herança clássica seria mobilizada para criticar uma concepção agostiniana de mundo da Idade Média tardia, que concebia o homem como irremediavelmente decaído, e a política, consequentemente, como um processo essencialmente de coerção, o qual busca manter a ordem pública pelo uso da força $^{417}$. Segundo Bradshaw, o humanismo do norte limitou-se a um período mais ou menos preciso, entre a última década do século XV ao início da Reforma, quando dá lugar à oposição entre protestantes e católicos ${ }^{418}$.

Esta concepção foi compartilhada por Margo Todd. Mas, enquanto Bradshaw enxerga no surgimento da Reforma o ocaso deste humanismo que vicejou no início do período Tudor (em virtude de sua incompatibilidade com a inspiração agostiniana dos reformadores), Margo Todd, ao contrário, considera que o humanismo erasmiano exerceu uma grande influência no movimento de Reforma que viria depois.

\footnotetext{
${ }^{417}$ Bradshaw, "Transalpine Humanism". In: Burns, J. H. The Cambridge History of Political Thought, pg. 115

${ }_{418}$ "Chronologically it spans what may be described as northern humanism's epic phase: the period from roughly the last decade of the fifteenth century when, with the writing of such scholars as Robert Gaguin in France, Conrad Celtis in Germany, and John Colet in England, humanist discourse in the north acquired a native voice, down to the late 1530s when, with the death of the generation of Erasmus and Bude, and the burgeoning of the Reformation and the Counter-Reformation, northern humanism lost its discrete character as a cultural force - succumbing to the role of handmaiden in the service ofa variety o f other cultural forces." Bradshaw, "Transalpine Humanism", pg. 95
} 
A ética social humanista que os puritanos achariam tão atraente era bíblica em sua apologética, eclética em suas fontes, mundana em suas preocupações, mas religiosa em seus objetivos, prática em sua metodologia, e ativista em sua abordagem. Era um humanismo distintamente cristão, voltado à formulação de um modelo para $o$ comportamento piedoso, que se aplicaria igualmente para o príncipe e o comum, o clérigo e o leigo. A reconstrução moral da ordem social foi seu objetivo último - e sua atração suprema para os reformadores protestantes. ${ }^{419}$

Para Todd, os reformadores tinham muito em comum com os humanistas do norte: a crítica da corrupção eclesiástica, a ideia de uma superioridade ética do estoicismo romano e dos primeiros cristãos em comparação com a igreja medieval, etc. Além disso, os humanistas do norte "aspiravam redesenhar o comportamento individual, social e político, de acordo com as linhas definidas pelos textos antigos considerados como mais instrutivos - a Bíblia, os trabalhos dos Pais da Igreja e os moralistas gregos e romanos"

James McConica considera que Erasmo desempenhou um papel fundamental na obtenção do apoio necessário para que esta mudança ultrapassasse as fronteiras. Foi ele quem teria conseguido galvanizar correntes dispersas do final do século XV: "o conhecimento textual humanista, o neoplatonismo florentino, o pietismo da devotio moderna da Holanda e o movimento de reforma de Windesheim, além de uma gama de descontentes de classe média, de repente conscientes de seu poder e suas necessidades"421. A philosophia Christi, centro em torno do qual se formou o círculo erasmiano, era voltada basicamente para compreensão da mensagem dos Evangelhos e para a imitação de Cristo. Além disso, buscava apoio para a doutrina nos textos dos Padres da Igreja e no estudo das obras filosóficas antigas (em especial gregas) como preparação para a leitura dos textos bíblicos. Esta preparação se dava de duas maneiras:

\footnotetext{
${ }^{419}$ Todd, Christian humanism and the puritan social order, p. 22

${ }^{420}$ Todd, Christian humanism and the puritan social order, p. 23.

${ }^{421}$ McConica, English humanists and reformation politics, pg. 14.
} 
por um lado os filósofos pagãos permitiam que se compreendesse o contexto em que Cristo viveu e em que, mais tarde, tinham sido escritos os Evangelhos; por outro lado, a filosofia ética grega cumpria o papel de formadora do caráter. Erasmo sustentava ainda que qualquer verdade contida nos textos dos filósofos só poderia provir de uma única fonte, que era Deus ${ }^{422}$. De modo que, aos seus olhos, seria possível compatibilizar, em alguma medida, a filosofia pagã e o cristianismo.

Dois traços essenciais, inseparáveis e inter-relacionados, distinguiam os humanistas cristãos. Eles eram tão ardentemente devotados à literatura da antiguidade cristã - os primeiros Padres e o Novo Testamento - quanto à literatura da antiguidade pagã; e eles acreditavam apaixonadamente que embebida em ambas as literaturas estava a sabedoria que poderia melhorar os homens e, muito mais importante, renovar a moribunda sociedade cristã de seus próprios dias temporal e espiritualmente, desde a cabeça até seus membros. ${ }^{423}$

Assim, a abordagem de Erasmo e dos humanistas cristãos de seu círculo diferia muito da dos escolásticos e se concentrava em seguir a letra do texto, com o auxílio da gramática, em busca do sentido original, afastando-se da obscuridade contida no vocabulário dos teólogos e se aproximando da linguagem natural, com vista a um público mais amplo.

Em todo o corpo dos escritos de Erasmo esta convicção era o tema constante: um retorno às Escrituras e às antigas fontes da Cristandade proveria um remédio soberano necessário para a decadência contemporânea. (...) Seu impacto reside no amplo apelo aos homens educados que esperavam ver restaurada a integridade na religião e na vida pública. Pois, acima de tudo isso, o chamado para o retorno ad fontes formou o credo de uma laicidade educada e desperta, e o laicismo do pensamento de Erasmo é a característica mais importante como incitação à reforma. ${ }^{424}$

\footnotetext{
422 “(...) embora ninguém tenha ensinado mais perfeitamente e mais efetivamente que Cristo, entretanto pode-se encontrar nos livros dos pagãos muito que concorda com Seu ensinamento (...). Os estóicos entenderam que ninguém era sábio a menos que fosse bom (...). O que poderíamos dizer disso, senão que muitos - notadamente Sócrates, Diógenes, e Epiteto - apresentaram uma boa porção de Seu ensinamento? (...) Cristo ensinou e apresentou a mesma doutrina. Erasmus, Paraclesis, pp. 100, apud. Todd, Christian humanism and the puritan social order, pgs. 29-30.

${ }^{423}$ Hexter, More's Utopia: the biography of an idea, pg. 53.

${ }^{424}$ McConica, English humanists and reformation politics, pg. 16.
} 
A defesa da laicidade e da ampliação do papel de uma comunidade de leigos levou Erasmo a se preocupar com a disponibilização não somente traduções dos textos dos filósofos e dos Padres da Igreja, mas também de manuais e paráfrases, entre outros escritos de sua própria lavra. Estes são o espírito e a letra do Enchiridion militis christiani, um manual de piedade cristã que buscava prover o homem leigo com as armas do conhecimento das Escrituras na sua batalha contra o mal. Os comentários das Escrituras são extraídos de Paulo e dos Pais da Igreja. Esta visada afastada da teologia escolástica e mais favorável à leiga rendeu duras críticas a Erasmo por parte dos teólogos tradicionais, sobretudo da Universidade de Louvain, em especial após a publicação do Elogio da loucura, em 1511, e por conta do seu projeto de publicar uma edição do Novo Testamento corrigida a partir dos manuscritos gregos.

Entretanto a oposição a Erasmo se intensificou em Louvain, a partir de 1514, e é interessante abordar o contexto em que isso se deu. Em sua introdução ao volume 15 das obras completas de More, Daniel Kinney afirma que, para se compreender o conflito de uma maneira adequada, é preciso levar em conta que a gramática e a retórica estavam inseridas no curriculum tradicional como disciplinas preparatórias para os níveis superiores de estudos. A crítica de Erasmo implicava justamente numa transformação desta estrutura, do material e da metodologia.

Assim como o Elogio da loucura de Erasmo atacou a suposição tradicionalista básica de que os métodos da dialética aristotélica forneciam os meios mais convincentes e diretos 
para se expor os ensinamentos de Cristo, assim também seu projeto de destacar discrepâncias entre a versão do Novo Testamento na Vulgata e os textos gregos originais desafiava mesmo a suposição mais básica de que o sentido literal dos ensinamentos de Cristo estava prontamente acessível sem que fossem necessários recursos frequentes a lições de gramática. ${ }^{425}$

Em oposição a isso os teólogos insistiam no caráter subordinado da gramática e da retórica frente à dialética e à teologia. Neste sentido, entre as críticas à iniciativa de uma nova edição dos Evangelhos estava a que questionava a qualificação de Erasmo para tanto: afinal, como um simples gramático poderia revisar e retificar o que fora estabelecido na Vulgata por gerações de teólogos?

É preciso lembrar ainda que o quadro no interior do qual tais críticas ocorriam era atravessado por tensões diversas, e havia o risco de que elas evoluíssem para algo mais concretamente ameaçador. Uma oportunidade neste sentido acabou emergindo por conta de um ataque lançado contra Erasmo pelo teólogo Maarten van Dorp. Segundo Fleisher, Dorp era amigo e correspondente de Erasmo e, até então, tinha se mostrado um apoiador de suas ideias e projetos. Aparentemente, tendo diante de si a chance de entrar para o conselho da faculdade de teologia da Universidade de Louvain, Dorp muda de posição e se coloca como porta-voz de grupos mais tradicionalistas ali presentes, formulando suas críticas e objeções em duas cartas, na primeira em um tom mais leve, e de forma mais dura e contundente na segunda ${ }^{426}$.

\footnotetext{
${ }^{425}$ Kinney, Introduction to The Complete Works of St. Thomas More, vol. 15, pg. xix-xx.

426 "Após seu encontro com Erasmo em meados de 1514, Dorp escreveu a ele uma carta alegando relatar as objeções de outros teólogos de Louvain à leviandade do Elogio da loucura e à temeridade da intenção de Erasmo de publicar todas as discrepâncias entre a tradução Vulgata do Novo Testamento e o original grego. De acordo com Erasmo, a carta jamais foi entregue; ele a viu primeiro meses depois em Antuérpia, onde um amigo tinha conseguido uma cópia por acaso. Erasmo esboçou uma resposta apressada no final de maio de 1515, que ele expandiu e alterou levemente para rápida publicação com Damiani Senensis elegeia (Basel, August 1515). Dorp respondeu à primeira versão desta carta reiterando e tornando ainda mais contundentes suas primeiras críticas e introduzindo outras novas em uma carta datada de 27 de agosto de 1515. Esta carta também aparentemente jamais foi entregue; Erasmo a leu pela primeira vez em uma cópia providenciada por More." Kinney, Introduction to The Complete Works of St. Thomas More, vol. 15 , pgs. xxii-xxiii.
} 
O risco colocado pelas cartas de Dorp estava na possibilidade de que elas pudessem catalisar os grupos que se opunham ao humanismo, dando início a um movimento de supressão dos projetos humanistas por toda a Europa. E o fato de que este receio não era exagerado havia ficado claro por conta da perseguição sofrida neste mesmo período por Joannes Reuchlin. Reuchlin era um destacado humanista alemão que tinha se dedicado ao estudo do grego e do hebraico ${ }^{427}$ e realizara um trabalho semelhante ao projeto de Erasmo, revisando os Salmos Penitenciais a partir de textos hebraicos. Aconteceu que, em 1509, Johannes Pfefferkorn, um judeu recém-convertido, deu inicio a uma campanha pela destruição dos livros sagrados hebreus, obtendo o apoio do inquisidor de Colônia, Hochstraten. Ciente da barbárie que esta campanha representava, Reuchlin encarregou-se de defender a preservação das obras, e para tanto escreveu um panfleto intitulado Augenspiegel. Hochstraten, porém, reafirmou sua concordância com Pfefferkorn, e o próprio Augenspiegel foi condenado à fogueira, em 1512, com o apoio das faculdades de teologia de Colônia, Paris e Louvain. Os humanistas percebem que este processo, além de visar diretamente um dos seus, opunha-se mesmo ao espírito de seus projetos e, com o auxílio de Erasmo quanto à organização, constroem um movimento de apoio a Reuchlin ${ }^{428}$. Por meio de sua influência na corte imperial e no papado, eles conseguiram, por fim, que em 1516 o papa revertesse as decisões do inquisidor.

Neste contexto, é compreensível, portanto, que as cartas de Dorp tenham sido recebidas com preocupação por More e que ele, em outubro de 1515, tenha escrito em

\footnotetext{
${ }^{427}$ Ele acaba mesmo por tornar-se uma das maiores referências sobre língua e cultura judaicas na Europa deste período, tendo publicado, por exemplo, a Rudimenta Hebraica, um misto de gramática e dicionário, em 1506.

428 'Erasmo ajudou a organizar o contra-ataque dos 'poetas', o nome pelo qual seus oponentes desdenhosamente se referiam aos humanistas para distingui-los dos dialéticos e teólogos, homens que eram genuinamente preocupados com a verdade e não com ficção." Feisher, Radical reform and political persuasion in the life and writings of Thomas More, pg. 73.
} 
resposta uma longa carta, que é considerada um importante documento humanista, com fortes críticas às formas assumidas pela dialética e a teologia em certos círculos escolásticos. Como bem sintetiza Fleisher, Dorp, em sua segunda carta, retomando as concepções dos teólogos tradicionalistas, sustentava que

a teologia demandava treinamento técnico e habilidade em dialética como um instrumento para chegar a seus objetivos: o estabelecimento e a elaboração sistemática das verdades da fé pela razão especulativa. Neste sentido, a teologia era uma ciência, a ciência da doutrina da igreja. Uma educação literária e familiaridade com a linguagem e as letras, o treinamento e o conhecimento possuídos pelo gramático e pelo retórico não os qualificam com teólogos, ainda que este conhecimento se conjugasse com uma íntima frequentação das Sagradas Escrituras. Como More entendia isso? Dorp não distinguia entre literatura e ciência e entre retórica e dialética para conciliá-las, mas para enfatizar sua diferença, se não completa oposição, e para insistir na superioridade e domínio da teologia e dialética sobre a retórica no curriculum das artes. A dialética ou lógica, que era chamada a arte das artes e a ciência das ciências por muitos escolásticos medievais, era obviamente, na maneira de pensar de Dorp, o mais adequado instrumento para a teologia. ${ }^{429}$

Em contraposição a isto, More insistirá em que a gramática, longe de ser uma disciplina ancilar, era uma ciência que exigia a mestria em todas as outras. O homem de letras é aquele de visada mais ampla. O que More faz é nada menos que inverter o edifício escolástico, por onde reencontramos aqui a concepção de Erasmo.

\footnotetext{
"Gramático" é sinônimo de "homem de letras" (litteratus), cuja área de estudo passa por toda a espécie de literatura, isto é, toda disciplina. Por esta razão, embora ninguém que não tenha estudado dialética possa ser chamado de dialético, ninguém que não tenha estudado aritmética possa ser chamado de aritmético, e assim por diante no restante das artes, na minha opinião ao menos, um homem só pode ser chamado "homem de letras" se conhecer todos os ramos da ciência. ${ }^{430}$
}

\footnotetext{
${ }^{429}$ Feisher, Radical reform and political persuasion in the life and writings of Thomas More, pg. 81.

${ }^{430}$ Carta 4 "To Martin Dorp" In: Selected letters, pg. 13
} 
Thomas More (a quem Erasmo dedicara o Elogio da Loucura, encarregando-o também da defesa da obra ${ }^{431}$ ) compartilhava com Erasmo este desejo por um cristianismo mais simples, douto, laico e mais consubstancial à vida. Deste modo, era natural que ele criticasse certas concepções de lógica ensinadas nas escolas, as quais se pautavam por um formalismo vazio.

\begin{abstract}
Agora este livro, A Pequena lógica ${ }^{432}$, o qual é assim chamado, suponho, porque tem muito pouca lógica, vale a pena examinar, com suas suposições, como são chamadas, suas ampliações, restrições, e apelações, e passagens nas quais ocorrem regrinhas, não somente tolas, mas falsas mesmo, como, por exemplo, as regras pelas quais se devem distinguir entre estes e outros enunciados similares: "um leão que um animal é mais bravo" ( $A$ Lion than na animal is braver) e "um leão é mais bravo que um animal" ( $A$ Lion is braver than an animal), como se eles não significassem a mesma coisa. A mesma diferença existe entre "vinho eu bebi duas vezes" (Wine I've drunk twice) e "duas vezes eu bebi vinho" (Twice I've drunk wine) - uma grande diferença, quer dizer, de acordo com estes lógicos, mas na realidade nenhuma (...). E em algum suposto caso possível, como eles chamam, este enunciado será verdadeiro, "o papa eu chicoteei" (The Pope I have whipped), enquanto, supondo o mesmo caso, será falso "eu chicoteei o papa" (I have whipped the Pope) - se isto quer dizer que aquele que é agora papa foi quando menino surrado por mim. Realmente, aqueles que ensinam tais coisas na velhice merecem apanhar toda vez que ensinem isso aos meninos. ${ }^{433}$
\end{abstract}

\footnotetext{
431 "O julgamento a meu respeito ficará realmente a cargo de outro; de todo modo, a não ser que o amorpróprio tenha me enganado, elogiamos a loucura, mas não de todo loucamente. Mas responderei já à falsa acusação de mordacidade: sempre se permitiu a homens engenhosos a liberdade de zombar impunemente das características da vida cotidiana dos homens, contanto que essa licença não transborde em raiva. Por isso me causa mais admiração a delicadeza dos ouvidos de nossos tempos, que já não podem suportar quase nada, a não ser títulos solenes. E mais: verás alguns religiosos que, de modo absurdo, suportam os mais graves ultrajes contra Cristo mais facilmente que uma salpicada da mais leve brincadeira sobre um pontífice ou um príncipe, especialmente se isso tem relação com o seu pão. (...) Mas para que digo tudo isso a ti, um advogado tão notável que até as piores causas poderias defender da melhor forma? Adeus, eloquentíssimo More, e defende com teu ardor esta tua Moria." Erasmo, Elogio da loucura, pg. 36-37.

${ }^{432}$ Em nota, Elizabeth Rogers faz a seguinte afirmação: "Parua Logicalia was the title for more than one textbook of logic, notably for that by Peter the Spaniard, Pope John XX, 1277, and another by Marsilius of Inghen, ex-Rector of Paris and cofounder of the University of Heidelberg, 1386." More, Selected Letters, pg. 20, nota 11. Mas, segundo Martin Fleisher, “(...) embora More não o indique diretamente, está claro a partir de evidências internas que o livro ao qual ele se refere é Summulae Logicales de Pedro da Espanha, cuja metade final era chamada de Parua Logicalia. Praticamente a partir do momento de seu aparecimento em meados do século XII o texto de Pedro dominou o campo, e permaneceu o texto padrão para os cursos de arte em dialética até o primeiro quarto do séc. XVI." Fleisher, Radical reform, and political persuasion in the life and writings of Thomas More, pg. 83.

${ }^{433}$ Carta 4 "To Martin Dorp". In: More, Selected letters, pgs. 20-21. Cf. também o Elogio da loucura, pgs. 133-134: "Quem, com efeito, teria percebido, se nossos sábios não no-lo houvessem ensinado, que não seria cristão aquele que dissesse que estas duas orações têm mesmo sentido: matula putes, "penico, cheiras mal', matula putet, 'o penico cheira mal', ou ollae fervere, 'ferver à panela', e ollam fervere, 'ferver a panela'? Quem teria podido livra a Igreja das trevas, tão grandes, de uns erros que nunca ninguém teria sequer percebido em suas leituras, se esses não os tivessem marcado com seus grandes selos da Universidade?"
} 
Por vezes, as sutilezas produzidas por estes dialéticos, diz More, têm como resultado a expansão de "suas fronteiras muito além dos limites da natureza", até que não fazem mais qualquer sentido; são tão nonsense quanto a gramática ensinada nas escolas, uma espécie de pesadelo, "que, ao curso dos anos é extremamente capaz de perverter o juízo até mesmo das mentes mais vibrantes”. Contra isso, o que More parece propor é uma relação mais prática, mais simples e mais viva, tanto com a gramática quanto com a dialética.

De fato, Dorp, sou quase levado a acreditar que um grande número de opiniões que são objeto de extensas e amargas batalhas (...) têm pouco a ver com lógica ou não contribuem muito para o seu aprendizado. No estudo da gramática, por exemplo, é suficiente aprender as regras que podem ajudar a falar latim e entender o que outros escreveram em latim, mas não com a mente preocupada em buscar inumeráveis regras e envelhecer em meio a letras e sílabas. Assim também, no estudo da dialética eu consideraria suficiente, uma vez que se tenha ensinado a uma pessoa a natureza das palavras, a força das proposições, e depois disso as regras para os silogismos, fazer a aplicação imediata da dialética, como um instrumento, aos outros ramos do aprendizado. Aristóteles indubitavelmente tinha esta mesma ideia em mente; todo o seu tratamento da dialética consiste naquelas dez categorias supremas, ou das coisas ou dos nomes, mais um tratado sobre proposições, e finalmente, as regras para silogismos, aqueles que levam a uma conclusão necessária, aqueles que persuadem com probabilidade e aqueles que envolvem sofismas ${ }^{434}$.

Assim, More procura colocar as coisas nos seus devidos lugares, que ele julga reconhecer no uso original delas, enquanto que a dialética estaria agora sendo superestimada, mais do que isso, efetivamente deturpada pela introdução de uma "miscelânea de monstruosidades sem sentido, as quais eram mantidas distintamente separadas pelos antigos, mas que agora levam à completa destruição das artes liberais" ${ } 435$. O resultado desta deformação era, aos olhos de More, o de que aqueles que se afainavam em tais estudos tornavam-se antes versados tão somente em disputar e

\footnotetext{
${ }^{434}$ Carta 4 "To Martin Dorp". In: More, Selected Letters, pg. 19.

${ }^{435}$ Carta 4 "To Martin Dorp”. In: More, Selected Letters, pg. 19.
} 
procurar a vitória acima de tudo. A este respeito, é significativa uma anedota incluída na carta a Maarten van Dorp, que More conta a título de exemplo deste tipo de teólogo que ele tem em vista.

Eu certa vez jantei com um mercador italiano que era tão douto quanto rico, e ele era extremamente rico. Estava conosco na mesa um religioso que era teólogo; um destacado controversista, ele tinha recentemente vindo do continente para se engajar em controvérsias em Londres a respeito de alguns problemas sobre os quais tinha estado ponderando e que tinha trazido consigo. Sua intenção era descobrir nesta arena de controvérsia quais eram as capacidades dos ingleses e construir uma reputação, a qual já tinha em seu país, entre nosso povo. (...) Entretanto, na mesa, não importa qual declaração fosse feita por quem quer que fosse, não importa quão cuidadosa e cautelosamente modificada ou pensada, mal ela tinha deixado os lábios da pessoa e ele prontamente a despedaçava com um silogismo; mesmo que o tema da conversa não tivesse nada a ver com teologia ou filosofia, e fosse completamente estranho à sua profissão. Entretanto, no início do jantar ele tinha deixado claro que nada poderia ser estranho à sua profissão, afirmando que defenderia os dois lados de qualquer questão.

O mercador iniciou então uma espécie de jogo com o teólogo introduzindo gradualmente questões mais ligadas à teologia. Não importava, porém, qual fosse a questão, se alguém ousava defender algum lado, o teólogo imediatamente passava a atacá-lo; se alguém criticava alguma coisa, ele prontamente a defendia. A situação seguiu assim por um tempo até que, a certa altura

o mercador percebeu que o teólogo não era tão bem versado nas Escrituras quanto na prática de tergiversar e começou a brincar com o sujeito e por algum tempo apresentou argumentos de autoridade. Ele inventava no calor do momento algumas breves citações para apoiar sua posição. Depois de criar livremente estas citações, nenhuma das quais jamais tinha sido ouvida, ele indicava as referências: uma era de alguma Epístola de são Paulo, outra de uma Epístola de são Pedro e outra de um texto dos Evangelhos. Ele tinha o cuidado de não omitir sequer os números dos capítulos em suas referências; e se uma obra tinha dezesseis capítulos, ele deliberadamente citava do vigésimo. Enquanto isso, o que o nosso ótimo teólogo estava fazendo? Ao lidar com as questões anteriores ele tinha sido definitivamente hábil (...). Mas estas citações falsas ele tinha dificuldade em evadir, enquanto se voltava de um lado para outro, mas ele conseguiu evadi-las. Tal é a eficácia da habilidade aliada à prática nas discussões. Ele não sabia coisa alguma a respeito do texto das Escrituras; tampouco duvidava que aquelas fossem citações verdadeiras, e considerava um pecado sério não se curvar e não se submeter à autoridade das Escrituras, mas uma terrível desgraça bater em retirada derrotado; 
embora encurralado por argumentos muito sutis, perceba quão habilmente este Proteus conseguiu escapar às armadilhas. Assim que alguma opinião não existente, presumidamente das Sagradas Escrituras, era citada contra ele, dizia: "esta é uma ótima citação, meu caro senhor, mas este é o modo pelo qual eu entendo o texto". Então, ele dava uma explicação por distinção. Em um sentido, ele admitia, ela dava razão a seu oponente; o outro sentido era seu meio de fuga. E se o mercador insistisse que o significado correto da passagem não era o que o teólogo tinha dado, o sujeito jurava por tudo que era mais sagrado que tal era a interpretação daquela passagem dada por Nicholas de Lyra. ${ }^{436}$

A postura impertinente e belicosa do controversista se assemelha à de Trasímaco e à do jurisconsulto da casa do Cardeal Morton. O gosto pela disputa e a tentativa de ganhar a qualquer custo denunciam um compromisso maior com o amor-próprio e com a vitória do que com a verdade. $\mathrm{O}$ exemplo, entretanto, expõe não apenas uma atitude que não condiz com a virtude e a concórdia cristã, mas também a ignorância efetiva de quem pretende ter conhecimento e decisão sobre as verdades da fé. Assim, é com muita razão que Erasmo, sob a máscara da Loucura, afirma que alguns "se comprazem com seus próprios aplausos da forma mais satisfatória, de modo que, ocupados noite e dia com estas agradabilíssimas cantilenas, não lhes resta sequer um pouquinho de tempo livre para folhear uma única vez o Evangelho ou as Epístolas de Paulo."437

Desta maneira, embora tome o cuidado de dizer que nem todos os teólogos se comportam desta forma, More procura minar as bases sobre as quais se alicerçam a pretensões de autoridade intelectual e moral dos teólogos dados a disputas de minúcias. Assim, o ethos de certos controversistas se revela plenamente na triste figura que fazem, quando, já velhos e tendo se afastado das arengas, logo sua língua perde o fio que costumava ter e emudecem, pois era apenas nisso, na arte da disputa, que consistia toda a sua sabedoria.

\footnotetext{
${ }^{436}$ Carta 4 "To Martin Dorp". In: More, Selected Letters, pg. 31-32. Em nota, Elizabeth Rogers explica que "Nicholas de Lyra (c. 1265-1349) comparou a versão do Antigo Testamento da Vulgata com o texto hebreu, usou comentários judaicos e foi muito independente em sua atitude em relação às interpretações tradicionais. Ele tinha um notável senso histórico e crítico."

${ }^{437}$ Erasmo, Elogio da loucura, pg. 133.
} 
Por fim, como uma maneira de evitar esta ênfase exagerada nas sutilezas do discurso, More insiste no trabalho necessário de recuperação dos originais, realizado por Erasmo e outros humanistas, como, por exemplo, as traduções que Linacre estava fazendo de algumas obras de Aristóteles e dos comentários de Alexandre de Afrodísias, bem como na importância do conhecimento do grego para se ler estas obras na língua original. Com relação a este último ponto, isto é, o estudo de grego, ele recorre à sua experiência pessoal, lembrando o quanto determinadas passagens de Aristóteles eram ininteligíveis para ele a partir das traduções, mas se mostravam claras no original, e emenda uma critica a dois comentadores que eram expoentes da ala tradicional: Cajetan, geral dos Dominicanos e um dos responsáveis pelo fortalecimento da causa dos adversários de Reuchlin; e Alberto, o Grande, o campeão dos albertistas. Na sua argumentação, More não aborda questões específicas dos textos sagrados, aqueles a respeito dos quais os teólogos julgam possuir monopólio do saber. Em vez disso, sua crítica incide na leitura e nos comentários que estes fazem das obras de Aristóteles, um filósofo pagão, portanto franqueado a todos os estudiosos, mas que forneceu as bases para a dialética, "ciência das ciências".

\begin{abstract}
Alberto, que chamam "o Grande", em referência a Alexandre, o Grande, que reclama para si o mérito de ter fornecido uma paráfrase de Aristóteles, deveria na verdade ter dito que nos deu uma paródia desta obra, pois embora seu trabalho tenha sido o de expressar em outras palavras o sentido das de Aristóteles, o que ele faz é introduzir significados que são diametralmente opostos. ${ }^{438}$
\end{abstract}

A defesa humanista de uma linguagem clara, modelada na escrita dos antigos, estava, assim, associada ao impulso reformador progressista identificado por Bradshaw

\footnotetext{
${ }^{438}$ Carta 4 "To Martin Dorp”. In: More, Selected Letters, pg. 53
} 
e Margo Todd e insidia diretamente na autoridade dos teólogos; e se pudermos tomar como medida a resistência que o aparentemente simples trabalho filológico de recuperação das fontes suscitou - sobretudo em determinados setores estabelecidos dentro e fora das universidades mais tradicionais - o seu sentido político era suficientemente contundente.

Fleisher, que analisou cuidadosamente a carta a Dorp, demonstra como More, valendo-se de argumentos retóricos se utiliza da seguinte estratégia: por um lado, aproxima a dialética da retórica; por outro, valoriza os usos comuns da linguagem e os significados comumente aceitos, ao mesmo tempo em que minimiza o papel da ars em favor do ingenium e do exercício, acrescentando ainda a necessária erudição obtida a partir da frequentação das bonnae literae. ${ }^{439}$

Assim, do ponto de vista de More, não praticar a dialética ensinada nas universidades europeias não implicaria em desconhecimento de dialética, já que a literatura desempenharia este papel formador melhor do que qualquer manual. ${ }^{440} \mathrm{E}$ também a frequentação dos textos dos antigos que tornaria possível descobrir a pouca diferença que há entre a dialética e a retórica, o que permitiria ainda a More afirmar que, se Dorp admite que "a retórica é um dom especial" de Erasmo, então não faria sentido negar que ele domine também a dialética.

Filósofos de não pouca importância sustentaram corretamente que a dialética e a retórica não diferiam mais que o punho e a palma da mão, porque o que os dialéticos sustentam de forma mais estrita, os retóricos explicam mais copiosamente, e assim como o primeiro atinge com a ponta da lâmina, o último, pela sua força brilhante prostra completamente e destrói. ${ }^{441}$

\footnotetext{
${ }^{439}$ Fleisher, Radical reform and political persuasion in the life and writings of Thomas More, pgs. 88-93.

${ }^{440}$ De acordo com Fleisher, é por esse motivo que, para More, "a fonte da dialética, como a fonte das outras artes da linguagem, gramática e retórica, deverá ser buscada nas bonae literae e não na Parua Logicalia ou qualquer outro manual de lógica". Fleisher, Radical reform and political persuasion in the life and writings of Thomas More,pg. 93.

${ }^{441}$ Carta 4 "To Dorp". In: Selected letters, pg. 15.
} 
Aqui More se apoia em Cícero ${ }^{442}$ e Quintiliano $^{443}$ (os non infimi Philosoforum), para "negar uma distinção fundamental entre retórica e dialética e para assimilar a última à primeira"444. Entretanto, afirma Fleisher, é possível ainda que, dentre estes filósofos de não pouca monta, estivesse também incluído Aristóteles, embora este último não empregue a imagem do punho e da palma.

$\mathrm{O}$ tratamento que Aristóteles dá à dialética e à retórica tem muitas afinidades com a própria posição de More. Entretanto, a fim de evitar uma possível confusão, deve-se assinalar que para More o termo "dialética" é mais amplo em escopo que em Aristóteles. Aristóteles usa o termo para denotar um tipo de raciocínio a partir de premissas prováveis, as quais primariamente investigou no tratado chamado Tópicos. Ele não nos oferece nenhum termo para o conjunto de suas investigações lógicas, as quais nós denominamos Organon e das quais os Tópicos formam apenas uma parte. Os acadêmicos medievais empregam o termo "dialética" em uma maneira completamente não-aristotélica para designar toda a lógica ${ }^{445}$.

É neste último sentido mais abrangente que More está empregando o termo "dialética", entretanto, diferente dos escolásticos, ele o faz de maneira a inverter o edifício da concepção escolástica, atribuindo primazia ao que Aristóteles efetivamente chamava de dialética (ou seja, aquilo que é tratado no volume dos Tópicos), subordinando a ela o restante do conjunto do Organon. Além disso, Aristóteles também concebe a dialética como próxima da retórica ${ }^{446}$.

Por outro lado, o uso da retórica pensado por More, e também por Erasmo, não é aquele que Aristóteles tinha em vista ao classificar em três tipos: judiciário, epidídico e deliberativo. Como se trata de outro contexto, "a retórica com a qual More estaria

\footnotetext{
${ }^{442}$ Cicero, Orator, 32.113.

${ }^{443}$ Quintiliano, Instituição oratória, 2.20.7

${ }^{444}$ Fleisher, Radical reform and political persuasion in the life and writings of Thomas More, pg. 89.

${ }^{445}$ Fleisher, Radical reform and political persuasion in the life and writings of Thomas More, pg. 91.

${ }^{446}$ Fleisher, Radical reform and political persuasion in the life and writings of Thomas More, pg. 91
} 
preocupado é aquela de acordo com as necessidades do professor e do pregador, quando eles buscam instruir o jovem, exortar o velho e inspirar as pessoas de todas as idades a levar uma boa vida cristã ${ }^{447}$, procedimento este que, para More, consiste na imitação de Cristo e do modo de vida do cristianismo primitivo. "A instrução moral então agradavelmente (e, no entanto, firmemente) implantada no estudante foi pensada pelos humanistas cristãos acima de tudo para ser prática e concreta; era para ser um conhecimento aplicado" ${ }^{448}$. Com este sentido prático em vista, o que se entende por filósofo não é alguém que se dedica à filosofia especulativa até os cabelos se agrisalharem, mas sim o prudente dotado de experiência (não é a toa que são estas características que são elogiadas em Hitlodeu), cujo propósito é ensinar e comunicar. "Foi o direcionamento para educar para a vida que motivou os reformadores humanistas a elevar a filosofia moral sobre a teologia e a metafísica, e a retórica sobre a ética"449. Daí a preocupação com uma linguagem inteligível e com o discurso belo e prazeroso e capaz de mover. Por este motivo,

More minimizou as diferenças entre arte e ciência como formas e níveis de conhecimento. Isto é exibido entre outras maneiras na sua tendência a assimilar ciência à arte, o mais ao menos abstrato e teorético. $\mathrm{O}$ fato de que More emprega os termos disciplina, ars e scientia como sinônimos é a evidência de um movimento para rebaixar a scientia ou episteme que pareceria bastante característico da tradição retórica.

A assimilação da ciência à arte é acompanhada de outra tendência a assimilar a arte às letras ou literatura ${ }^{450}$.

Para More, assim como para outros humanistas, a arte e a beleza do discurso estão intimamente ligados à filosofia e ao posicionamento político. Se se aposta numa comunidade de leigos para a refundação da república cristã, é necessário mover e se

\footnotetext{
${ }^{447}$ Fleisher, Radical reform and political persuasion in the life and writings of Thomas More, pg. 98.

${ }^{448}$ Todd, Christian humanism and the puritan social order, p. 46.

${ }^{449}$ Todd, Christian humanism and the puritan social order, p. 46.

${ }^{450}$ Fleisher, Radical reform and political persuasion in the life and writings of Thomas More, pg. 101.
} 
fazer entender. Isto, porém, está ligado a outro elemento muito importante, que precisa ser levado em consideração. Como vimos, a república utopiana tem seu sentido último ligado ao prazer. Mas há um aspecto deste prazer a que não havíamos nos referido até agora, o qual diz respeito a pura e simples fruição, uma certa joie de vivre que está dispersa por toda a descrição da Utopia: nos incensos que perfumam os jantares coletivos, nos jardins bem cuidados das residências, na contemplação das estrelas. Mas sua formulação mais clara se dá na filosofia utopiana.

Ou será que um mal numa vida agradável, ou seja, prazerosa? (...) Quanto à beleza, à robustez, à destreza, os utopienses cultivam-nas de bom grado como verdadeiros dons da natureza que são também aprazíveis. Melhor ainda, como condimentos que tornam a vida aprazível, buscam prazeres que entram pelos ouvidos, pelos olhos, pelas narinas, que a natureza quis que fossem peculiares do homem (de facto, nenhuma outra espécie de animais se detém a olhar para a elegância e a para a beleza, ou se deixa impressionar pelo encanto dos odores, a não ser que seja para distinguir alimentos, nem se apercebe da escala dos sons e da sua harmonia ou dissonância). ${ }^{451}$

Na peroração de Hitlodeu, é possível ainda entrever, no momento em que ele se refere ao "fundamento que sustenta todo o sistema", o prazer no alívio daquele que é rico embora nada possua.

$\mathrm{Na}$ realidade, quem pode ser mais abastado do que aquele que vive totalmente sem qualquer ansiedade, de ânimo desanuviado e tranquilo? Não receia pelo que há-de comer, não vive atormentado pelos queixumes insistentes da esposa, não teme pela pobreza do filho, não vive preocupado com o dote da filha, mas está confiante de que há gente de boa nota a tomar conta do alimento e do bem-estar seu e de todos os seus - da esposa, dos filhos, dos netos, dos bisnetos, dos trinetos e de toda a série de descendentes, por mais longa que seja. ${ }^{452}$

Esta valorização do prazer advém de uma recuperação de Epicuro que teve inicio no séc. XV com a publicação da tradução de Ambrogio Traversari para o latim da

\footnotetext{
${ }^{451}$ Utopia, pgs. 164; 176; Vtopia, pgs. 332; 342-343.

${ }^{452}$ Utopia, pg. 238; Vtopia, pg. 410.
} 
Vida dos filósofos eminentes de Diógenes Laércio ${ }^{453}$. E a reabilitação de Epicuro pelos humanistas do norte se deu em virtude de uma releitura numa chave cristã. No que diz respeito a Erasmo, o contato com a obra De Voluptate ac de vero bono de Lorenzo Valla parece ter cumprido um papel importante. Surtz afirma que Erasmo menciona ou utiliza Diogenes Laércio sessenta e quatro vezes nas Chiliades e supõe que provavelmente deve ter mostrado a More o "Contemptu mundi e discutido com ele as ideias, as quais ele desenvolveu mais tarde no colóquio 'O Epicurista",454. É neste último, diz Surtz, que Erasmo “defende o paradoxo de que 'não há maior Epicurista que aqueles cristãos que vivem uma vida piedosa""455. Para se compreender melhor como é possível sustentar o paradoxo vale a pena verificar os termos em que Erasmo defende a vida monástica no Contemptu mundi:

\begin{abstract}
Epicuro nega que se deva admitir aqueles prazeres dos quais resultam grandes problemas. Quanto a nós, não cometemos fornicação ou adultério. Não nos empanturramos ou embebedamos como os devassos; sóbrios vemos o nascer do sol, sóbrios vemos o pôr do sol, ambos os quais eles negam ter visto. Todas estas coisas jamais acontecem sem trazer mais sofrimento que deleite. Não somos nem capazes nem ávidos por nos tornar ricos, ou sermos tornados ilustres por alguma dignidade oficial. Mesmo nisso não somos infiéis ao ensinamento de Epicuro. Pois, uma vez que são marcados por pouco prazer e muita aflição, sabiamente relutamos em obter muito pouca conveniência ao preço de um enorme dano. Em acréscimo, ele ensina que deve-se às vezes suportar dores a fim de se escapar de dores ainda maiores, e igualmente que devese superar prazeres a fim de se alcançar prazeres maiores. O que fazemos? Sofremos vigílias noturnas, jejuns, solidão, silêncios e outras privações semelhantes por temor de que tenhamos que suportar dores maiores... Acreditai que perdemos nosso prazer? Era uma questão não de perda, mas de troca, e de uma tal troca que recebemos numerosos prazeres intensos em lugar de poucos prazeres triviais. ${ }^{456}$
\end{abstract}

Embora, como nota Surtz, em Utopia Epicuro a princípio não pudesse ter cidadania plena, uma vez que sua filosofia nega valores fundamentais dos utopianos (a

\footnotetext{
${ }^{453}$ Cf. Surtz, "Epicurus na Utopia", pgs. 91-92; cf. também Don Cameron Allen, "The Rehabilitation and his teory of pleasure in the early renaissance", passim.

${ }^{454}$ Surtz, "Epicurus in Utopia", pgs. 92-93.

${ }^{455}$ Colloquies, 2. 327, apud. Surtz, "Epicurus in Utopia", pgs. 93.

${ }^{456}$ Opera, 5. 1257, apud. Surtz, "Epicurus in Utopia", pgs. 96-97.
} 
saber, as crenças antes mencionadas: de que a alma é imortal, de que a benevolência divina a destinou à felicidade, e de que após a morte ela terá retribuição para o bem e o mal praticados), ainda assim, há muito da filosofia de Epicuro em Utopia, mesmo que temperada com a visada cristã. Temperada, mas não totalmente subsumida a ela, uma vez que Utopia, embora como uma república filosófica compartilhe, no que tem de admirável, da sabedoria divina, não é inteiramente cristã. Assim, é de inspiração epicurista a filosofia moral utopiana, que associa a virtude ao prazer, assim como a compreensão de que o máximo prazer corporal é ausência de perturbação.

Por conta dessa característica e de outros aspectos que discutiremos a seguir a partir da análise de Hexter, não é possível identificar a Utopia a um mosteiro nem a vida dos utopianos a uma vida monástica, como o fez Chambers. ${ }^{457}$ Segundo Hexter, More identifica três males fundamentais nas repúblicas européias: a preguiça (sloth), a ganância (greed) e o orgulho ou soberba (pride). Embora, dentre tantos pecados mortais, seja este o "grande triunvirato que governa o império do mal", mesmo entre eles não há igualdade de cidadania. A preguiça se origina do costume que os nobres têm de se cercarem de parasitas, pessoas fortes o bastante para o trabalho, mas que passam o dia bebendo, jogando e em atividades ruinosas, de modo que acabam se acostumando com a inação. A ganância é um mal que os homens compartilham com outros animais, mas ela não possui nenhum atrativo por si mesma, antes se origina do medo que se tem da privação. De modo que "este pecado, fadado a perturbar uma sociedade pecuniária, é

\footnotetext{
${ }^{457}$ Cf. Chambers, Thomas More, pg. 136: "É significativo que as casas religiosas sejam as únicas instituições européias que se diz que os utopianos aprovam. E com razão, pois em utopia, embora a regra do celibato esteja necessariamente ausente, a idéia monástica é atuante. O Estado utopiano é tão suntuoso quanto o foram muitas casas religiosas. Mas o utopiano, como o monge ou frade, não pode possuir nada. Todos em Utopia devem usar o hábito comum (em uma carta a Erasmo encontramos More chamando-o de franciscano) (...) Suas horas de trabalho, de recreação, os próprios jogos que fazem, são todos regulamentados. Não há jogos tolos ou perniciosos, como os dados. (...) Os utopianos comem em refeitórios, começando todo almoço e jantar pela leitura de algo relativo às boas maneiras e à virtude.”
} 
essencialmente parasita da insegurança inerente àquele tipo de sociedade e não tem raízes próprias. É sustentado antes pelas raízes institucionais do próprio sistema de propriedade" ${ }^{458}$. Entretanto, o mesmo não ocorre com o orgulho, que se enraíza no coração dos homens, e somente deles, "por contar dentre as coisas gloriosas exceder os demais na supérflua e vã ostentação de coisas". Segundo Hexter, aqui se encontraria o coração da matéria. Este mal, profundamente enraizado na sociedade e na alma de todos os homens, dispensaria seu veneno e debilitaria o corpo social. De maneira que, se uma parte da sociedade tem uma vida pior do que as bestas de carga, não é senão para sustentar estas superfluidades, nelas incluídos o luxo, os prazeres desonestos, os trabalhos inúteis e os parasitas. Disso Hexter conclui que as instituições de Utopia são criadas com o objetivo de impedir o desenvolvimento destes males, sobretudo o orgulho.

Assim, o discurso utopiano não seria uma nostálgica comunidade medieval, uma irmandade agrária cristã, em contraposição à sociedade moderna. Ademais esta interpretação não está presente em nenhum dos amigos ou leitores contemporâneos de More. Ele não poderia, então, ser visto como o "último medieval". Tampouco ele seria um homem de classe média, lutando contra os resquícios do feudalismo e da Idade Média representados pela nobreza decadente ${ }^{459}$. Para Hexter, o discurso utopiano

é então baseado no diagnóstico dos males da cristandade do século dezesseis; atribui aqueles males ao pecado, e primariamente ao orgulho, e prescreve remédios para esta desastrosa infecção da alma do homem, planejados para inibi-la, se não para erradicá-la. (...) [É] a produção de um humanista cristão dotado singularmente com os olhos e a mente de um estadista, uma ampla experiência mundana, e uma consciência de uma sensibilidade incomum, que via o pecado, e especialmente o pecado do orgulho, como o câncer da república. ${ }^{460}$

\footnotetext{
${ }^{458}$ Hexter, More's Utopia: the biography of an idea, pg. 74.

459 Ames, Citizen Thomas More and his Utopia, passim.

${ }^{460}$ Hexter, More's Utopia: the biography of an idea, pg. 76 e 78.
} 
Tendo afastado a identificação da Utopia a um monastério e a uma visão medieval do mundo, Hexter nota, no entanto, que algumas regras da cidade ideal lembram as dos mosteiros beneditinos (assim como as da República de Platão). Como por exemplo, as refeições comuns, o dever de trabalhar, as restrições de saída, a falta de privacidade, etc. Ele não deixa de assinalar também que a principal regra dos mosteiros está ausente, justamente aquela criada para subjugar o orgulho dos monges.

\begin{abstract}
A perfeição no modo de vida monástico era medida numa escala ascendente na base da qual estava o pecado do orgulho e o progresso na vida religiosa estava calcado principalmente na ascensão sobre aquele pecado. De modo que entre pobreza, castidade e obediência, a regra de são Benedito, embora exigisse todas as três, dava mais atenção à obediência, especialmente a obediência do monge ao abade, por que a submissão envolvida é o passo decisivo no desenraizamento do orgulho da vontade obstinada. ${ }^{461}$
\end{abstract}

Como argumento adicional, Hexter lembra que na Utopia, em contraste com o modo de vida dos demais, existe a figura dos monges que praticam o celibato, não comem carne e fazem o trabalho pesado voluntariamente, e ainda rejeitam o prazer. Por isso, são considerados santos.

Aqui obviamente nós temos os verdadeiros religiosos claramente distintos do resto dos utopianos. Há privação especial. Há o trabalho base para induzir e desenvolver uma humildade especial. Há a vocação especial, o chamado religioso. E finalmente há a irrelevância da sua existência para a estrutura social utopiana. Esta "seita" é em nada mais semelhante às ordens monásticas do que na independência da sua estrutura interna da sociedade ao redor. Precisamente porque não é o mundo, pode existir em qualquer lugar no mundo. Mas sua presença mesma em Utopia serve para enfatizar a diferença entre a melhor forma de república e uma comunidade monástica. ${ }^{462}$

Ainda que Utopia não seja uma idealização da vida monástica, por que More não se vale desta regra eficaz para submeter o orgulho? Simplesmente porque as instituições de Utopia não são formuladas unicamente para sanar este mal. Embora concordemos

\footnotetext{
${ }^{461}$ Hexter, More's Utopia: the biography of an idea, pg. 86.

${ }^{462}$ Hexter, More's Utopia: the biography of an idea, pg. 90.
} 
com o diagnóstico de Hexter sobre a origem social ou estrutural de determinados males, nos afastamos de sua interpretação quando este sustenta, juntamente com White, que o constructo utópico tem como objetivo combater os pecados da preguiça, da rapacidade e principalmente do orgulho. A eliminação destes males é pura e simplesmente consequência da reorganização social e não seu objetivo. O objetivo da república utopiana, coerente com a sua filosofia moral, é alcançar a felicidade (e o prazer que lhe é constitutivo), como resultado da justiça e da equidade, fundamentos da boa república. E, como aponta Fleisher, More é o único entre os humanistas a localizar a origem dos males nas próprias instituições sociais ${ }^{463}$.

Neste sentido, Quentin Skinner caracteriza a Utopia como uma crítica radical e humanista do próprio humanismo, pois foi a obra que tirou todas as consequências de um humanismo que criticava o aparato de que se cercavam os nobres e insistia na necessidade de se voltar para a verdadeira nobreza que é a virtude. Ora, o exercício da virtude e o reconhecimento da verdadeira nobreza só são possíveis numa república que derribe todas as distinções sociais, como nas antigas comunidades cristãs ${ }^{464}$. O diagnóstico de Skinner foi certeiro. Utopia realmente é uma crítica humanista ao humanismo, mas é também algo mais.

A república utopiana é também a expressão do humanismo cristão e carrega em si sua inerente contradição: busca amalgamar filosofia e cristianismo, a um tempo negando e reafirmando cada um deles. Utopia é e não é uma república cristã; Utopia é e não é pagã ou filosófica. Como os humanistas cristãos do período, trata-se de um particular com vocação para a universalidade, portanto, paira entre a concretude e a

\footnotetext{
${ }^{463}$ Fleisher, Radical reform and political persuasion in the life and writings of Thomas More, pg. 8.

${ }^{464}$ Skinner, As fundações do pensamento politico moderno, pg. 273-280.
} 
abstração. Utopia é uma república humanista, a condensação imagética da república das letras e, como o humanismo cristão, é um fenômeno do limiar da modernidade. 


\section{Apêndice}

Para se compreender melhor, porém, a configuração do humanismo do norte, bem como a localização da Utopia em seu interior, é necessário recuperarmos um pouco o processo de constituição da chamada República das Letras (litteraria res publica) e, principalmente, abordarmos alguns aspectos da figura de Erasmo que não discutimos até aqui. James Tracy se refere à República das Letras como "uma comunidade

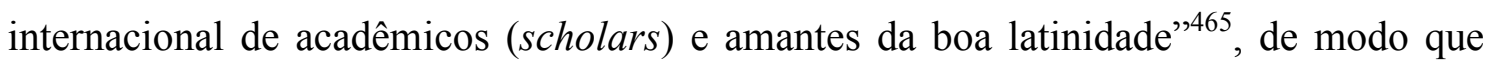
Peter Burke a caracteriza como "essencialmente uma comunidade imaginada"466. Tratase de um espaço a partir do qual Erasmo pôde construir sua imagem de intelectual universal, imagem que foi fundamental para que ele pudesse escapar da parcialidade, então um aspecto inerente e problemático da atividade humanista. De fato, Erasmo jamais conseguiu se conciliar com o sistema de patronagem e as implicações que esta relação acarretava.

O verdadeiro problema para Erasmo foi sua descoberta de que as relações costumeiras de patronagem não permitiam que se separasse serviço e atividade intelectual. Isto porque a escrita de declamationes laudatórias com o objetivo de atribuir fama e glória necessariamente ligava Erasmo aos interesses políticos e, o que era mais significativo para ele, aos valores culturais dos patronos. Na Europa do norte, no séc. XVI, isto

\footnotetext{
465 Tracy, Erasmus of the Low Countries, p. 15

${ }^{466}$ Burke, "A República das Letras Europeia, 1500-2000”, pg. 277.
} 
significava, como o Panegyricus mostra amplamente, identificar-se com o ethos aristocrático e com a cultura da corte, os quais Erasmo considerava contraditórios com seus valores humanistas e cristãos ${ }^{467}$.

O discurso erasmiano e seu amplo programa de reformas se dirigiam ao conjunto da cristandade; desagradavam-lhe facções de todo tipo. "Abomino estas divisões de nomes. Sou cristão e reconheço a cristãos. Não tolerarei erasmistas", escreveria ele no prefácio da edição de 1519 dos Colloquia. De fato, a esta altura Erasmo já era considerado como um intelectual universal. Sua recusa a se vincular a uma corte, à casa de algum lorde ou mesmo a uma universidade favoreceu a composição de sua imagem de intelectual acima dos interesses particulares. Do mesmo modo, intelectuais do seu círculo de amigos também eram vistos como humanistas com vocação universal, ainda que seguissem as carreiras tradicionais dos humanistas e litterati de então.

Nas cartas que trocou com Andrea Ammonio é possível divisar como um monge errante passou a intelectual conhecido e respeitado. ${ }^{468} \mathrm{O}$ cruel sistema de patronagem era objeto de queixas constantes na troca de cartas. Não havia quaisquer garantias com relação à promessas recebidas ou os valores dispensados eram muito insuficientes. Mesmo Ammonio, que era o secretário latinista do próprio rei, e anteriormente de Lord Mountjoy (ex-preceptor de Henrique VIII), revela em uma das cartas seu temor com relação à velhice.

Respondendo a queixas de Erasmo, mais vagas que as costumeiras a respeito de sua situação, Ammonio refere-se à fama e aos conhecimentos de seu amigo e conclui que Erasmo "não poderá deixar de encontrar patronos poderosos em toda parte". Ammonio é menos otimista em relação a si próprio: "Mas eu, a não ser que consiga reunir alguns meios para suportar meus anos de declínio em meio aqueles para os quais trabalhei tão

\footnotetext{
${ }^{467}$ Yoran, Between utopia and dystopia, p. 52-53

${ }^{468}$ No que segue acompanho a discussão desenvolvida por Yoran no seu livro Between utopia and dystopia.
} 
duramente, durante muitos anos, em com não poucos gastos, não sei onde poderei obter refúgio, vendo que envelheci bastante nesta escuridão cimeriana". ${ }^{469}$

Além disso, ainda havia a espera da contrapartida, que, muitas vezes, comprometia moralmente o patrocinado com o seu patrono. Apenas num único momento Erasmo escreveu um panegírico, mas o seu desconforto se revela no resultado, um misto de discurso laudatório e exortação.

Erasmo nunca mais compôs outra oratio laudatória para um patrono. Ele mais tarde escreveu, em uma linha acrescentada à carta dedicatória da edição de 1516 do Panegyricus, que Felipe "prometeu-me o mundo se eu estivesse disposto a ir para a corte como um membro de sua casa", mas que ele tinha declinado a oferta de se tornar um cortesão $0^{470}$.

Em 1514 toda a conjuntura havia se transformado e o destino de Erasmo começou a mudar. Os príncipes considerados promessas humanistas estavam conduzindo os principais reinos da Europa. Francisco I seria coroado em 1515 na França, Henrique VIII reinava na Inglaterra e Carlos (futuro imperador Carlos V do Sacro Império) em breve reinaria na Espanha. Além disso, Giovanni de Médici havia se tornado papa Leão X e Maximilliano I era imperador do Sacro Império. Em 1517, Erasmo diz, em uma carta de suas cartas, que na Europa estava se iniciando uma espécie de Era de Ouro. Henrique VIII, no início de seu reino, parecia cumprir a promessa de sua educação humanista. A França, sob Francisco I, conheceu um período de florescimento das letras e da tolerância. Erasmo então já goza de uma reputação sem precedentes.

Era pela boa fortuna de Erasmo que muitos de seus amigos humanistas e admiradores estavam a serviço de príncipes temporais e eclesiásticos. Ele foi capaz de procurar uma carta do Papa Leão X para imprimir com seu Novum Testamentum; o papa expressou "não pouca satisfação" com o prospecto de uma edição revisada e ampliada: "Prossiga

${ }^{469}$ Yoran, Between utopia and dystopia, p. 43.
${ }^{470}$ Yoran, Between utopia and dystopia, p. 53. 
no mesmo espírito: trabalhe para o bom público, e faça tudo que puder para trazer um empreendimento tão religioso para a luz do dia." ${ }^{471}$

Através do estudo de Yoran é possível compreender como a República das Letras e a própria reputação de Erasmo foram cuidadosamente construídas por um esforço conjunto no interior do qual um papel bastante relevante foi desempenhado pelo movimento humanista alemão. No âmbito da Alemanha o humanismo tomara um sentido e uma forma um pouco distintos. Havia ali certo ressentimento em relação ao que era visto como uma hegemonia cultural italiana, ao qual se associava uma oposição à dominação religiosa exercida a partir de Roma. Havia já há algum tempo uma forte oposição à escolástica, enquanto que a Igreja era vista como estando profundamente corrompida e necessitando, por isso, de uma intensa reforma. No contexto da Alemanha daquele período, então, os humanistas alemães desenvolviam um esforço voltado para “a promoção de uma cultura 'nacional' alemã, o estabelecimento da educação liberal nas cidades e, acima de tudo, o avanço da reforma religiosa" ${ }^{\natural 72}$. Com isso, desde o final do séc. XV eles tinham conseguido se estabelecer em cortes eclesiásticas e leigas, nas cidades e mesmo em várias universidades. Apesar disso, faltava-lhes uma figura de destaque, alguém que pudesse funcionar como símbolo e referência unificadora do movimento, sendo ao mesmo tempo uma espécie de líder.

Erasmo não era alemão, mas holandês, e certamente não simpatizava com considerações nacionalistas. Ocorre, porém, que, por conta da política de casamentos dos Habsburgos, a Holanda era, naquele momento, parte do Sacro Império, de modo que sua nacionalidade efetiva podia ser minimizada, fornecendo aos humanistas alemães uma figura de destaque a qual podiam recorrer. Por outro lado, o movimento

\footnotetext{
${ }^{471}$ Tracy, Erasmus of the Low Countries, pg. 72

${ }^{472}$ Yoran, Between utopia and dystopia, p. 59.
} 
era efetivamente humanista, de modo que sua conotação "nacional" podia também ser minimizada por Erasmo e muitos de seus amigos, sendo inclusive difícil saber até que ponto ele tinha conhecimentos sobre este aspecto. De qualquer modo, a aspiração alemã acabou por se associar com os desejos do conjunto de humanistas que orbitava em torno de Erasmo, os quais buscavam fortemente promovê-lo como parte dos esforços de promoção do próprio movimento humanista em geral.

Isto contribuiu para que a figura de Erasmo fosse mais e mais celebrada e glorificada, a princípio dentro da Alemanha, e depois por quase toda a Europa. Uma das primeiras grandes manifestações deste processo esteve na forma como ele foi recebido quando de sua viagem a Basel em 1514: "Humanistas em uma cidade após a outra celebravam sua chegada. Em Strasbourg e Sélestat ele foi mesmo recebido oficialmente pelos magistrados locais" ${ }^{\prime 473}$. Mais indicações a respeito podem ser encontradas frequentemente em sua correspondência a partir deste ano, com Erasmo sendo tratado muitas vezes não como um colega humanista, e sim como um patrono ou um soberano. De fato, cinco volumes reunindo seleções da correspondência de Erasmo chegam a ser publicados entre 1515 e 1519 (dois deles por Peter Giles e Beatus Rhenanus), sempre incluindo várias cartas neste tom.

Um caso que é destacado por Hanan Yoran a este respeito é o da correspondência entre Erasmo e Willibald Pirckheimer. Pirckheimer era um importante humanista alemão, de família muito rica, e com uma extensa carreira administrativa e diplomática, tendo então se tornado membro do conselho imperial. Em suas cartas, ele manifesta o máximo apreço por Erasmo, dizendo repetidamente que valoriza sua amizade acima da de todas as pessoas altamente colocadas a quem era ligado. Mas um

\footnotetext{
${ }^{473}$ Yoran, Between utopia and dystopia, p. 61.
} 
dos aspectos mais interessantes que transparece em suas cartas mostra o caráter curioso da posição alcançada por Erasmo por meio desta consagração. Em uma delas ele diz que

Você de fato deve ser saudado, pois seus trabalhos obterão o favor de Deus e dos santos, e do mundo. Eu, por outro lado, estou obrigado a acompanhar os afazeres e a agitação das questões jurídicas e as querelas dos príncipes, no que mesmo agradar a Deus é talvez impossível; e quão maldosamente a fortuna trata aqueles que se entregam aos negócios públicos, a história tem muitos exemplos para mostrar. ${ }^{474}$

Pirckheimer traça, portanto, um contraste particular entre sua situação e a de Erasmo. Não se trata, aqui, simplesmente do fato do último se encontrar em uma posição consagrada, ainda que não oficial - trata-se mais exatamente do fato de que Erasmo não se encontrava ligado à vida pública no modo tradicionalmente adotado pelos humanistas. Com efeito, a ocupação de um cargo público, com o desenvolvimento mesmo de uma carreira, era usualmente considerada a consumação do comprometimento de um humanista com a sociedade, sendo a forma por excelência de união entre vita contemplativa e vita activa. A consagração de Erasmo, porém, colocara-o em outra situação, livre das pressões sociais e profissionais no sentido de se vincular à estrutura política vigente. Pelo respeito e fama que angariara, ele passava então a se relacionar com esta estrutura não mais propriamente como um de seus elementos submetidos, mas como um intelectual independente, desvinculado, um puro representante do bem comum e dos interesses universais.

De fato, como vimos pela correspondência entre Erasmo e Ammonio, as tentativas de dedicação à vita activa no interior da estrutura política e social então existente não podiam deixar de produzir conflitos e frustrações na experiência dos humanistas. Isto acabou por levar a uma postura fortemente crítica frente a esta estrutura

${ }^{474}$ Apud Yoran, Between utopia and dystopia, p. 67. 
política, o que transparece de modo bastante intenso na História do rei Ricardo III escrita por More ${ }^{475}$

Considerada uma das obras mais representativas da historiografia humanista produzidas na Inglaterra, a História do rei Ricardo III não deixou, porém, de intrigar muitos leitores. Frequentemente tomada como uma crônica dotada de um sentido moral, suas muitas incorreções factuais, trocas de nomes e datas, bem como outros elementos semelhantes, sempre causaram incômodo e foram alvo de críticas. O livro cobre o período entre a morte do rei Eduardo IV em 9 de abril de 1483 e a tomada do trono por seu irmão Ricardo em 26 de junho do mesmo ano. À primeira vista, ele parece se concentrar na apresentação dos crimes de Ricardo ao longo desta trajetória, retratando-o em termos costumeiros como um tirano inescrupuloso. Uma leitura mais cuidadosa, porém, depara-se com as ambiguidades presentes na caracterização de figuras que deveriam contrastar com ele. Tal é o caso, por exemplo, do próprio Eduardo IV, cujo elogio por More é atravessado por restrições e reparos laterais que acabam por compor uma imagem bastante crítica e, no fim, mesmo próxima da de Ricardo. E mesmo personagens tradicionalmente elogiados e apresentados como exemplos morais, como a rainha Elizabeth, são representados de tal forma que suas motivação última parece se reduzir a uma sede ilimitada de poder.

A partir disso, surgiu então uma segunda leitura da obra, segundo a qual

não há diferenças qualitativas entre Ricardo e os outros atores políticos. Todos eles são reduzidos a marionetes ocas movidas por um único motivo: um desejo impiedoso e descontrolado pelo poder. (...) A usurpação de Ricardo deixa de parecer um evento único. Ao contrário, é um evento normal, completamente explicável pela lógica da política. Dadas as motivações, intenções e desejos que moldam a realidade política, o tipo de tragédia descrita parece quase inevitável. ${ }^{476}$

\footnotetext{
${ }^{475}$ Sobre a análise a seguir, cf. o capítulo 5 do livro Between utopia and dystopia, de Yoran.

${ }^{476}$ Yoran, Between utopia and dystopia, p. 140.
} 
Tal leitura, por sua vez, parece ganhar um sentido mais definido se levarmos em conta a metáfora central que atravessa a obra: a política como um grande teatro. Esta metáfora é parte de uma dicotomia básica e constitutiva do texto, opondo um comportamento humano "normal", tanto bom quanto mal, a um comportamento político "teatral".

Como mostra Yoran, o livro apresenta vários elementos formais que parecem perturbar sua composição, desequilibrando-a, por exemplo, pela expansão, em um texto em geral muito conciso, do tratamento de eventos e personagens aparentemente secundários. Tais são os casos da trama para a condenação de Lorde Hastings, do discurso de Buckingham sobre a retirada do príncipe herdeiro do santuário de Westminster e da digressão sobre Jane Shore.

Com efeito, More constrói a situação que leva à queda de Hastings por meio de um obscuro contraste entre este e Ricardo. Considerado a partir da metáfora teatral, porém, o contraste ganha sentido. Sendo a política um teatro, saem-se melhor nela, como hábeis políticos, aqueles que se mostram hábeis atores. Assim, a morte de Hastings não é a punição merecida de pecados que não são pagos por outros personagens igualmente pecadores - ela assinala antes a maestria teatral com que Ricardo conduz toda uma encenação para obter seu objetivo, sendo Hastings vitimado por uma inocência que o torna cego para a peça teatral de que entretanto ele toma parte.

Algo semelhante ocorre no caso do longo discurso pronunciado por Buckingham para convencer os membros do clero de que o direito de santuário deveria ser violado. Tomado em contraste com a colocação do cardeal, segundo a qual nunca houvera "um rei tão pouco devoto, que violasse aquele lugar sagrado", e em conjunto com a metáfora teatral, a extensão dedicada a este elemento também ganha sentido. Ocorre que a sacralidade do santuário pertencia a uma ordem natural e tradicional das coisas. $\mathrm{O}$ 
discurso de Buckingham, porém, participa habilmente da teatralidade, a qual triunfa contra justiça e a tradição.

O caso mais interessante dos três é o de Jane Shore. Personagem minimamente relevante para a narrativa, sua história e seu destino são, entretanto, longamente abordados. Inicialmente ela aparece como cúmplice da rainha em uma acusação falsa de Ricardo, segundo a qual ambas haviam tentado enfeitiçá-lo. Incapaz de provar suas afirmações, Ricardo decide acusá-la de comportamento licencioso, pelo que ela seria condenada a uma humilhante procissão de penitência. Neste ponto More passa então a narrar a história de Jane, contando como ela tinha caído inicialmente em um casamento infeliz, ganhando depois um lugar na corte como concubina do rei Eduardo e, mais tarde, de Hastings, e descrevendo sua situação no momento em que o livro era escrito: uma velha mendiga vivendo nas ruas de Londres. Diferente do que acontece no caso das outras personagens, o relato sobre Jane Shore é marcado por um tom de simpatia e comiseração. Qual a razão para esta diferença? Ocorre que é Jane quem fornece o contrates para todas as outras personagens.

More sublinha o traço distintivo desta mulher: ela nunca usou erroneamente seu poder político. Ao contrário, "ela nunca abusou de modo a prejudicar qualquer homem, e sim para confortar e aliviar a muitos: quando o rei estava contrariado, ela o pacificava e suavizava seu espírito; quando os homens perdiam o seu favor, ela obtinha-lhes de volta a sua graça. Para muitos que tinham cometido altas ofensas, ela obteve o perdão". Jane Shore nunca participou do teatro da política. Seus pecados, resultado de sua sedução pelo brilho e o luxo da corte e pelo prazer da atenção real, são qualitativamente diferentes dos crimes de outros protagonistas. Eles pertencem à economia natural cristã de pecado, remorso e punição. Não é a inocência que faz dela a única personagem humana em Ricardo III, mas a inocência de crimes políticos. ${ }^{477}$

O problema colocado pelo contexto político para a ambição dos humanistas de se dedicar à vita activa aparece, assim, de forma bastante drástica. Trata-se de um

\footnotetext{
${ }^{477}$ Yoran, Between utopia and dystopia, p. 144.
} 
contexto caracterizado por mentiras, ilusões - trata-se, enfim, de um âmbito em que a teatralidade está a serviço da mesquinharia e da ambição, triunfando contra a verdade. Neste sentido, a comunidade imaginada por More seria o seu negativo, não somente no seu conteúdo, mas também na sua forma. 


\section{Considerações Finais: Forma e Política na Utopia de More}

Uma característica incontornável de Utopia é a sua forma poética. Todos os comentadores de um modo ou de outro tiveram que lidar com este aspecto. Alguns a tomam como a principal chave interpretativa, muitas vezes minimizando o seu conteúdo, outros valorizam o conteúdo e atribuem à forma um papel secundário, ou a vêem como uma maneira de disfarce para o conteúdo - este sim importante. De fato, o conteúdo de Utopia não é de se negligenciar. Na verdade, é um dos objetos mais elevados desde a antiguidade. Trata-se de discutir a melhor República e isto já está indicado no título completo da obra: On The Best State of Commonwealth and on the New Island Utopia.

Mas, por que deveríamos separar o que já vem unido de nascença? O fato é que Utopia, lugar nenhum, tem uma forma poética para tratar de um conteúdo elevado, a melhor República. Por que então não partimos desta duplicidade? Por que não tomarmos a forma como também doadora de sentido, sem negligenciar o fato de tratarse de uma obra política? Por que não pensarmos nesta forma tendo em vista o seu conteúdo e o seu conteúdo tendo em vista esta forma?

Sabemos que a obra Utopia na sua forma acabada é composta por dois livros, sendo o primeiro um diálogo e o segundo, em sua maior parte, um discurso. O livro I é 
aquele em que os problemas da Europa são discutidos e corresponderia à parte propriamente crítica da obra, enquanto que no livro II, em contraposição, apareceria a república ideal. A obra comporia assim uma espécie de díptico não pictórico: de um lado a imagem negativa da distopia, da não-república; de outro a utopia, a verdadeira república. Emoldurando tudo isso, temos quadras, sextilhas, e as cartas dos humanistas; além de um mapa e de um curioso alfabeto utopiano. No seu todo Utopia não deixa de ser uma obra coletiva, não somente pelas cartas que fazem parte de sua composição, mas também por conta do alfabeto e da quadrinha dos utopianos, que, como sabemos, não são da lavra de Thomas More, e sim de Peter Giles, ou ainda das notas marginais de autoria incerta, reivindicadas por Giles, mas também atribuídas a Erasmo. Esta é a obra na sua forma final, mas nem sempre foi assim. Porém, deixemos isso de lado por ora.

Voltemo-nos à conversa que se deu em Antuérpia. Ora, Peter Giles por certo estava lá, e John Clement, que "também presenciou a conversação", lançou tempos depois uma pergunta a More que o deixou perplexo. Qual era a largura do Anidro? É importante que se escreva a Giles.

É que, tanto quanto eu me recordo, quando Hitlodeu contou como no local onde o rio Anidro se alarga, a ponte de Amauroto tinha quinhentos passos de comprimento, o nosso amigo John diz que há que subtrair duzentos e que a largura do rio nesse ponto não abrange mais do que trezentos. Rogo-te, pela minha parte, que faças por trazer à memória o assunto, pois, se coincidires com ele, eu também darei o meu assentimento, considerando ter cometido um lapso. Se, pelo contrário, tu próprio não se recordares, manterei a minha primeira redação, como fiz de acordo com o que me lembro. De facto, procurarei ao máximo que no livro não haja falsidades; assim, se algo há de menos esclarecido, prefiro assumir uma falha e não incorrer numa mentira, já que me importa mais ser honesto do que ser sagaz.

Seria aconselhável atalhar o mal, perguntando ao próprio Rafael, ou de viva voz ou por carta, o que importaria fazer, até porque outro percalço nos sobreveio (não sei mais se por culpa minha ou tua, ou do próprio Rafael): não me veio à mente a mim perguntar nem a ele ocorreu dizer em que parte do Novo Mundo fica situada a Utopia. ${ }^{478}$

${ }^{478}$ Utopia, 40; Vtopia, 220-221. 
Mas, a julgar pela carta de Giles a Busleiden, More ficará sem resposta, pelo menos no que respeita à segunda questão.

Quanto à perplexidade que More tem em indicar o lugar, não foi que Rafael tenha deixado completamente de o referir, ainda que só o tenha feito em poucas palavras e como que de passagem, como se o reservasse para outro local. Por certo, não saberei bem por que modo certo incidente menos feliz nos apanhou em falso a qualquer de nós nesse momento; foi o caso que, quando Rafael falava de tal tema, entrou um dos criados de More, chegou-se a ele para lhe dizer não sei o quê ao ouvido e, a mim, que escutava com grande atenção, foi um dos companheiros quem, ao tossir com mais ruído (devido ao frio que apanhara na viagem de mar, ao que suponho) me dificultou perceber o som das palavras do nosso interlocutor. ${ }^{479}$

Ao que parece o piedoso teólogo "que vive em ardente desejo de se deslocar até lá”480 terá que esperar até que Utopia finalmente passe a figurar nos mapas dos cosmógrafos, embora ela possa estar em algum, mas com um antigo nome ${ }^{481}$. Enquanto isso, esquadrinhamos o que temos em mãos.

Segundo James Romm, "várias tentativas têm sido feitas para discernir os padrões etimológicos dos nomes inventados de Utopia”. No início do séc. XVII, o filólogo holandês Gerhard Vossius se debruçou sobre o texto a fim de decodificar o significado dos nomes. Para cumprir a tarefa da melhor maneira, estabeleceu inicialmente uma metodologia de trabalho; no meio do caminho, entretanto, por conta das dificuldades enfrentadas, se viu obrigado a violá-la, terminando por abdicar da tentativa de solucionar completamente os problemas com os quais se deparou. $\mathrm{Na}$ carta intitulada "De Utopia Mori ac paradoxis in illa vocabulis agit" ele expressa as dificuldades ao seu interlocutor nos seguintes termos:

$\mathrm{Eu}$ espero ter dado uma resposta satisfatória a seu pedido no que respeita a estas questões. Exceto que você talvez considere que alguns destes termos parecem ter sido

\footnotetext{
${ }^{479}$ Utopia, 22; Vtopia, 213.

${ }^{480}$ Utopia, 42; Vtopia, 221.

${ }^{481}$ Utopia, 24; Vtopia, 212.
} 
compostos de maneira menos feliz, se os analisarmos da maneira acima. Eu não o negarei; mas não podemos deixar de culpar More ${ }^{482}$.

A tentativa do linguista James Simmonds ${ }^{483}$ de estabelecer um princípio de classificação geral das palavras utopianas é criticada por Room nos seguintes termos: quando alguns autores perceberam que a palavra "Zapoletas", povo mercenário, vizinho de Utopia, carregava no próprio nome uma crítica ("uma vez que seu primeiro elemento, $z a$-, representa uma rara variante dialetal de intensificação do prefixo grego dia-, e poletae, uma derivação inventada (nonce word) do verbo poleó ('vender'), que se parece confusamente com politai ('cidadãos'), mais comum em contexto etnográfico",484), presumiram que a partir daí poderiam extrair um princípio generalizável. Aplicando este raciocínio para o livro II, James Simmonds separou os nomes utopianos dos estrangeiros/não-utopianos e concluiu que os nomes utopianos eram variantes de negações de si mesmos, enquanto que os nomes dos povos nãoutopianos tinham um significado ético opaco. Entretanto, Romm demonstra que não é possível aplicar este esquema ao livro I e que mesmo sua aplicação ao livro II é discutível.

As palavras utopianas resistem à classificação definitiva e tornam o procedimento de nomeação virtualmente indiscernível. Ora o significado é fornecido pelo próprio texto e convém à forma da palavra, ora não; às vezes, é possível tão somente extrair um significado aproximado recorrendo à etimologia, mas em outros casos este resultado somente é obtido à custa de se violar muito a configuração da

\footnotetext{
${ }^{482}$ Romm, James. "More's Strategy of Naming in the Utopia", pg. 174.

483 O artigo que James Romm analisa de James Simmonds é: "More's Use of Names in Book II of Utopia”, Neueren Sprachen n.f. 10 (1961): 282-84.

${ }^{484}$ Romm, James. "More's Strategy of Naming in the Utopia", pg. 176.
} 
palavra $^{485}$. Assim, vimos anteriormente, a partir dos comentários de Surtz, que a palavra

Amauroto ("cidade fantasma", "cidade enevoada", "cidade obscura", entre outras) abrange um campo de significação que impede uma determinação absolutamente segura. Já Hitlodeu pode ser o "falador de nonsense", "falador de paradoxos" e até “contador de balela", enquanto que, Rafael, seu primeiro nome, é uma referência ao anjo que tem o poder de curar a cegueira ${ }^{486}$. No conjunto, mantém-se um jogo de referências cruzadas que produz instabilidade e impede a síntese.

No que respeita à semântica dos nomes a obra escapa continuamente a qualquer tentativa de captura por uma metodologia uniforme, pois neste aspecto o que se verifica é que o texto quebra a lógica linear, como mostra André Prévost no seu artigo L'Utopie:

\section{Le Genre Litteraire.}

A Utopia, com efeito, possui sua lógica própria, uma metalógica que permite as contradições formais. A primeira dessas contradições aparece nos conceitos negativos e vazios de toda substância que colorem o texto. Certamente o hábito embotou no leitor moderno a atenção ao absurdo do vocabulário de Utopia, mas é necessário redescobrilo. Utopia, por exemplo, evoca o absurdo: "o país que não existe"; escrevendo a Erasmo

\footnotetext{
${ }^{485}$ Para se ter uma ideia das dificuldades envolvidas, reproduzo os comentários de Vossius (extraídos do artigo de Romm) sobre as tentativas de traduzir os dias de festa utopianos (cinemernos e trapemernos, que ocorrem respectivamente no primeiro e último dia de cada mês), ambos anteriormente traduzidos pelo personagem Hitlodeu como primifesti e finifesti. Diz Vossius: "Poder-se-ia ter suspeitado que o nome deveria ser escrito "Cinemerinos', como se viesse da palavra kunos ["cachorro"] e hemerinos ["dias"], de modo que se referiria a dias de cão. Similarmente pode-se pensar o outro nome como derivado do mesmo hemerinos e da palavra tropes ["solstício de inverno"], de maneira que deveria ser entendido como "dias de inverno". Mas estas análises devem cessar, já que as palavras, neste caso, deveriam vir do grego, o que More não pretendia; de outro modo, ele não teria incluído sua própria tradução, primifesti e finifesti. Esta explicação não se coaduna bem com a ideia de uma origem grega. O mesmo é verdade das palavras "sifogranto" e "traniboro"..." Romm, James. "More's Strategy of Naming in the Utopia", pg. 175.

486 "Etimologicamente seu nome Hebraico significa 'curador divino' (302, n. 48, 31-32), e, como o 'remédio de Deus' ou o 'medicus', o anjo médico, curou a cegueira do velho Tobit e expulsou o demônio que perturbou Sara, cujo casamento com o filho de Tobit, Tobias, ele tinha arranjado: 'E o sagrado anjo de Deus, Rafael, foi enviado para curar ambos'. Igualmente importante para Utopia, ele era o guia para o jovem Tobias, que partiu em sua jornada para a cidade de Rey com um homem que ele conhecia como Azarias (o anjo disfarçado). Conforme as implicações destes temas foram traçadas, São Rafael tornou-se um médico simbólico que cura as almas e os corpos, e ilumina a escuridão das mentes. Assim, o Discurso sobre a Dignidade do Homem de Pico della Mirandola clama a Rafael, 'médico celestial, que possa libertar-nos pela filosofia moral e pela dialética como pelas drogas restauradoras'. E ele se tornou um tipo de peregrino e um guardião que guia os homens em suas jornadas tanto em sua vida como através dela para sua casa eterna no céu: 'também um anjo nos guiou para que não desviássemos do caminho. Tobias 5', como Bartolomeu escreve." McCutcheon, Elizabeth. "Thomas More, Raphael Hythlodaeus, and the Angel Raphael" pg. 23
} 
(Allen 11, p. 339 et 346) More a nomeia Nusquama, "Ilha de parte alguma". O lado absurdo da palavra não é simples fantasia. É um procedimento literário perfeitamente estudado ao qual More frequentemente recorre. É em vão, por exemplo, que o leitor tentaria representar Amauroto, a capital da ilha, pois ela é invisível. (...) Quanto ao rio Anidro que banha Amauroto, é um rio negativo, "um rio sem água". Os Acorianos são "um povo sem território"; os Alaopoletas, "cidadãos sem nação"; os Polileritas, "gente que só existe na palavra"; os Nefelogetas, "aqueles que "habitam as nuvens", os Anemólios, "habitantes do vento". Assim, os nomes de lugares ou de povos reafirmam sem cessar a parte de inanidade no interior da Utopia. Quanto aos personagens da ilha, eles são negações miméticas das funções que assumem. Hitlodeu significa "vã tagarelice"; os Zapoletas são "soldados venais"; ex-Barzanes, hoje Ademo é "chefe sem povo"; o Sifogranto é "o indicador da polícia"; Traniboro é "o chefe dos delatores". Em resumo, a toponímia e a antroponímia lembram sem cessar que Utopia é um mundo de sonhos vazios ${ }^{487}$.

Esta negatividade não está somente na semântica, mas se mostra também de uma maneira notável na estrutura das frases, em suas recorrentes litotes. André Prévost não deixa de notar o recurso à dupla negação e o interpreta, como já havia feito com a negatividade semântica, como um modo de provocar certa perplexidade para acentuar o caráter irreal da obra.

É preciso acrescentar as formas gramaticais privilegiadas, notadamente a dupla negação cujo objetivo é desorientar o espírito: ela obriga a atenção a se voltar para uma operação racional bastante complicada, inteiramente subjetiva e a desvia um instante do mundo objetivo. Esta dupla negação sistematicamente repetida contribui para dar ao universo utópico seu caráter evasivo e irreal. A este procedimento se acrescenta o tom escolhido para o estilo, o modo irônico, que consiste em exprimir o contrário do que se pensa com a intenção de melhor dizer o que se pensa. ${ }^{488}$

Em seu famoso artigo, "Denying the contrary: More's use of litotes in the Utopia" $^{489}$, Elisabeth McCutcheon chama a atenção para a frequência com que este recurso retórico aparece na Utopia: são cento e quarenta ocorrências em apenas cem páginas da edição de Yale. Por outro lado, McCutcheon lembra que a litotes (que

\footnotetext{
${ }^{487}$ Prevost, André. “L’Utopie: Le Genre Litteraire”, 162

${ }^{488}$ Prevost, André. "L’Utopie: Le Genre Litteraire", pg. 163

${ }^{489} \mathrm{McCutcheon}$, Elizabeth. "Denying the Contrary: More's use of Litotes in the Utopia". In: Moreana, no. 31-32 (Nov 1971): 107-122
} 
consiste em afirmar algo pela negação do seu oposto) é também considerada uma figura de linguagem banal e prosaica e como tal foi frequentemente desvalorizada no período Tudor por aqueles que buscavam utilizar uma linguagem mais ornada. O seu uso normalmente era indicativo de uma aproximação com a linguagem coloquial. Mas longe de evitá-la, como já foi observado, More a usou em profusão e de maneira bastante sutil e variada, a ponto de torná-la um elemento estético significativo ${ }^{490}$. Mais do que uma fórmula gramatical, como demonstra McCutcheon, a litotes neste caso merece destaque pelos efeitos que produz. Como elemento prosaico do discurso, a litotes, por vezes, aparece na Utopia como uma maneira de reforçar o caráter coloquial do diálogo, conferindo-lhe fluidez e naturalidade, de modo a disfarçar a arte. Afinal, More não está apenas reproduzindo o que ouviu?

\begin{abstract}
Sinto-me um tanto envergonhado, meu caríssimo Peter Giles, por estar a remeter-te com atraso de quase um ano, este livrinho sobre o país da Utopia, que não duvido tu esperarias no prazo de mês e meio, tanto mais que sabias que me ficava de fora o trabalho de invenção nesta obra, nem havia que pensar em estabelecer um plano de disposição, já que apenas havia que relatar o que contigo, bem ao teu lado, escutara a Rafael. Pela mesma razão, não havia tão-pouco nenhum motivo para retocar a forma de dizer, já que nem o seu discurso podia ter sido requintado, pois, primeiro, era feito a correr e de improviso, depois, era de um homem que, como sabes, não era tão bom conhecedor de latim como de grego. A minha redacção, quanto mais se aproximasse da sua simplicidade sem refolhos, tanto mais se acercaria da exactidão, a qual apenas neste tema devo o meu cuidado, e assim é. ${ }^{491}$
\end{abstract}

\footnotetext{
490 "More comumente usa non - há mais de sessenta exemplos. Adicionalmente, haud, uma partícula enfática, e nec e neque são usadas ao menos vinte e oito vezes. Ainda outras palavras de negação incluem haudquaquam, nusquam e tantum non. A construção como um todo é mais variada ainda. Litotes baseadas em adjetivos e advérbios são certamente comuns, e More ocasionalmente repete adjetivos tais como exiguus, insuauis, magnus e paucus, e uns poucos advérbios, tais como, dubie, facile, minus (termo mais recorrente), saepe, temere e unquam. Ele gosta de uma elegante construção também apreciada pelos clássicos - uma negativa seguida pela forma negativa de um adjetivo, como "non dissimiles" (128/18-19), "non imperiti" (52/18), "non indoctus" (48/32), "non inhonesti" (146/20-21), etc. Já as construções baseadas em nomes ou verbos ou ambas, de forma que uma ideia completa é duas vezes negada, como quando Rafael sublinha o absurdo de punir um ladrão e um assassino do mesmo modo e conclui "nemo est, opinor, qui nesciat" (74/4), ["não há ninguém, eu suponho, que não saiba"] não são infrequentes." McCutcheon, Elizabeth. "Denying the Contrary: More's use of Litotes in the Utopia", 108.

${ }^{491}$ Utopia, pg. 39 ; Vtopia, pg. 215-217.
} 
Mas, em outros momentos, a litotes, como expressão da modéstia, pode ser uma maneira moderada de elogiar, vituperar, criticar ou simplesmente discordar. Assim, ela é capaz de intensificar o discurso de maneira não evidente, tornando-o mais palatável para o interlocutor. No caso da Utopia este recurso se torna particularmente importante na medida em que nela se elogia profusamente pessoas e povos. No livro I, por exemplo, fala-se sobre os Polileritas, os Macários e os Acorianos, enquanto que o elogio aos utopianos ocupa praticamente a totalidade do livro II. Assim, os Polileritas são "populum neque exiguum, neque imprudenter institutum" ["um povo nada pequeno, não dotado de imprudentes instituições"] ${ }^{492} \mathrm{e}$

entre os mais simples estão marinheiros que são "non imperiti" [não imperitos] no oceano e no tempo (52/18); o cardeal Morton é uma companhia "non difficilis" [não difícil de agradar] (58/23-24); um tolo que ocasionalmente diz coisas "non absurda" [não absurdas] (80/27); (...) uma filosofia acadêmica a qual é "non insuauis" ["não é sem seu charme"] entre amigos (98/6).

Mas há construções mais complexas e sutis em que a litotes captura a atenção do leitor por meio do jogo de inversões e de referências cruzadas, como bem notou Prévost, produzindo certa desorientação, e assim, mobilizando a sensibilidade e a inteligência. É o caso do trecho da peroração em que Hitlodeu elogia a comunidade de bens nos seguintes termos: "Neque enim maligna rerum distributio est, neque inops, neque mendicus ibi quisquam. Et cum nemo quicquam habeat, omnes tamen diuites sunt" ["De fato, não há distribuição malevolente das coisas, nem alguém passa necessidade nem anda na mendicidade e, embora ninguém tenha coisa alguma, ainda assim todos são ricos"] $]^{493}$.

\footnotetext{
${ }^{492}$ Utopia, pg. 75; Vtopia, pg.256

${ }^{493}$ Utopia, pg. 238; Vtopia, pg. 410.
} 
Mas há outro exemplo analisado no artigo de McCutcheon, que é particularmente significativo, por ser o trecho que originalmente introduziria o livro II com os relatos sobre Utopia.

\begin{abstract}
"Nam Scyllas \& Celenos rapaces, \& Lestrigonas populiuoros, atque eiuscemodi immania portenta, nusquam fere non inuenias, at sane ac sapienter institutos ciues haud reperias ubilibet" ["De facto, Cilas e Celenos rapaces, e Lestrigones antropófagos e portentos imanes do mesmo jaez, não há quase nenhum lugar onde não se encontre, mas cidadãos a viverem de forma sábia e sã é que não se encontram em parte alguma"] (52/31-54/1). Esta sentença, com estas duplas negações de pensamento, cuidadosamente embora assimetricamente balanceada e suspensa, é talvez a melhor prova do efeito sofisticado e extraordinariamente complexo que More consegue alcançar com litotes. Subentendidos, ênfases, ironia, um rápido movimento da mente de um extremo para o outro, um tipo de dupla visão: todos estão presentes nesta astuta justaposição de toda sorte de horríveis monstros, de fato, tanto falaciosos quanto imaginários, ainda que tão "reais" (eles até têm nomes!) e a idealizada abstração dos "cidadãos sabiamente bem treinados" (53/39), os quais são imaginários por outras razões (as quais Utopia revelará). More subverte diferentes níveis de realidade quando ele contrasta os primeiros, os quais (traduzindo literalmente o negativo) você quase nunca encontra, com os últimos, os quais de modo algum você pode encontrar onde quer que você queira. Cruciais aqui são as perspectivas contrárias e as direções inversas construídas nas negações; os primeiros se movem em direção ao sempre a partir do nunca, os segundos, em direção ao nunca, não tanto a partir do sempre, mas do lugar em que você gostaria de pensar que houvesse alguns. Mas já que os primeiros não existem realmente, onde nós encontraremos os segundos? Em Utopia, lugar nenhum, em termos de história ${ }^{494}$.
\end{abstract}

A negatividade opera em vários níveis no interior do texto, desorientando e subvertendo aquilo que se tem por estabelecido: o afirmado passa pelo que é negado, o absurdo se torna plausível e a ilusão é ampliada pelo mais prosaico. O nome mesmo da cidade ideal produz uma espécie de vertigem. Em Utopia há um rio Anidro? Mas em "lugar nenhum” há um "rio sem água”. Utopia está no mapa? Ela é fugidia como Amauroto, de modo que se tentarmos capturá-la, aí mesmo é que ela escapa, como Ulisses: “- Meu nome é ninguém”.

\footnotetext{
${ }^{494}$ McCutcheon, "Denying the Contrary: More's use of Litotes in the Utopia”, pg. 109.
} 
Tudo se passa numa única jornada em Antuérpia: o encontro com Giles e o navegador na saída da missa, a conversa pela manhã no jardim, a pausa para o almoço, o relato de viagem à tarde. Afinal, como diz Prévost, com quem Aristóteles concordaria, uma "obra de arte deve ter uma unidade de forma"495. No díptico, imagem evocada também por Prévost e por Robert Elliott, é a distopia que se apresenta pela manhã; e à tarde, a Utopia. Entretanto, uma vez no jardim, o tempo e o espaço também se estilhaçam e se dissolvem. O tempo perde sua linearidade e se desdobra em camadas simultâneas; o espaço se amplia para além do mundo conhecido. Estamos no jardim, mas somos transportados para o Novo Mundo e de lá para a mesa do cardeal Morton em Londres e então para as proximidades da Pérsia, a terra dos Polileritas. De volta às cortes da Europa, somos conduzidos novamente ao Novo Mundo, conhecemos o modo de vida dos Macários, dos Acorianos e, por fim, dos Utopianos. Enfim, demos a volta ao mundo.

No centro do díptico Prévost coloca o filósofo moralista; Elliott, o satirista. Para o primeiro Hitlodeu conduz More, Giles, Clement, e também o leitor, da crítica do mundo conhecido para a hipótese de trabalho e, em seguida, para o apelo à reforma moral.

É assim que Hitlodeu chega a este novo instrumento crítico: o espetáculo da sociedade utopiana. Este quadro excita a imaginação criativa e o desejo de transformar o mundo. As exposições teóricas se revelam impotentes e, tendo fracassado as soluções reformistas, ele vislumbra medidas radicais: o princípio da comunidade de bens. Mas somente a hipótese de trabalho que apresenta o problema resolvido oferece à imaginação uma base suficientemente concreta para que a vontade a ela se vincule e para que as forças galvanizadas em torno deste espetáculo se abalem. Assim, o método utópico (instrumento crítico e hipótese de trabalho) revela sua fecundidade. Sua potência de encantamento é superior àquela da cidade ideal de Platão. A maneira concreta e viva pela qual se apresenta "a melhor das repúblicas" é mais estimulante que

${ }^{495}$ Prevost, André. “L’Utopie: Le Genre Litteraire”, pg. 164. 
uma elaboração abstrata a partir de uma ideia teórica de justiça. More, por este método, se mostra como criador. (...). More não se deixa levar pela ilusão de transformar as instituições. Sua intenção é mais profunda e conforme ao humanismo. É no homem que se deve pensar. $\mathrm{O}$ instrumento crítico que ele construiu, a descrição de instituições irrealizáveis, não serve senão para pôr a nu os defeitos do homem. É dentro do coração, do espírito e da vontade que estes defeitos devem ser reformados. Uma vez os costumes purificados, as instituições se reformam por si mesmas, as leis tornam-se mais equitativas pelos homens tornados mais sábios. A última lição da Utopia é uma lição de sagesse. $^{496}$

Eis por que, para Prévost, as palavras de Utopia são vazias de significado; são como bolhas de sabão e proclamam sua inanidade em toda parte, pois, para ele, "Utopia é um mundo de sonhos vazios", seu papel é excitar a imaginação e mover a vontade em direção a uma mudança que só poderia ocorrer em outro lugar: no interior do próprio homem.

Já para Elliott esta estrutura em negativo-positivo da Utopia (“o negativo que expõem de uma maneira humorística os males que afetam o corpo político; o positivo, que provê um modelo a ser imitado" ${ }^{\text {497 }}$ ) ainda que seja comum a muitas outras formas de discurso, tais como fábulas, sermões, etc, é “a forma básica característica da sátira em verso tal como esta foi escrita por Horácio, Persius e Juvenal"498, o que não deixa de ser significativo. Esta estrutura da sátira se caracteriza por uma maior extensão do negativo, mais humorístico, do que do positivo. A Utopia inverte esta relação, sobretudo no livro II, em que prepondera a descrição da cidade ideal: "a composição é largamente expositiva e, até o final, notavelmente não-dramática (uma característica infeliz da maioria das composições similares, obrigatória nas subsequentes utopias literárias)" ${ }^{\text {499 }}$. Associada a esta característica ainda há as vozes que se chocam e se combinam de acordo com o padrão: “a Utopia, como muitas sátiras em verso, é

\footnotetext{
${ }^{496}$ Prevost, André. “L’Utopie: Le Genre Litteraire”, pg. 167.

${ }^{497}$ Elliott, Robert. The Shape of Utopia, pg. 31.

${ }^{498}$ Elliott, Robert. The Shape of Utopia, pg. 31.

${ }^{499}$ Elliott, Robert. The Shape of Utopia, pg. 40.
} 
estruturada pelo encontro entre o satirista e o adversário”. Elliott rastreia em ambos os livros estas estruturas básicas em pares opostos. $\mathrm{Na}$ mesa do cardeal Morton, por exemplo, à crítica à economia e ao sistema penal, seguem-se sugestões para minimizar o êxodo rural e a pobreza, no caso da economia; e, no caso dos excessos de um sistema penal sem equidade, é apresentado o exemplo dos Polileritas, que encontraram uma maneira de fazer com que aqueles que cometeram crimes possam contribuir para o bem público. Porém, a crítica e sua solução não são simplesmente expostas, mas se apresentam em meio a um confronto entre Hitlodeu (identificado como o satirista) e o homem versado em leis (seu adversário). Algo semelhante ocorre nas discussões entre Hitlodeu e "More" até o final do livro I, quando o debate passa do tema da participação no conselho (que Elliott julga terminar em empate) para o comunismo. Neste caso, Utopia é a resposta positiva para as críticas de "More". Após a exposição, "More" “ainda não está convencido, mas as razões que ele dá, perquam absurde, não fazem sentido $" 500$ :

\footnotetext{
"More" deixa conosco, entretanto, uma manifestação das reservas que ele não apresentou para Hitlodeu - reservas sobre certas leis e instituições de Utopia fundadas, a seus olhos, "em não boas razões" (...) entre estas estão seus métodos para fazer guerra e seus costumes religiosos, mas o que ele tem principalmente em mente é "o principal fundamento de todas as suas instituições", a "vida e o sustento comunitários, sem qualquer intervenção do dinheiro". "More" deixa claras as bases de sua objeção: ao se livrar do dinheiro, "os verdadeiros ornamentos [vera ... ornamenta $]$ e honra da República, conforme sustenta a opinião comum, caem por terra". O que, na visão de "More", são os verdadeiros ornamentos e honra da república? São "nobreza, magnificência, esplendor, honra e majestade". Claro que é pra rir. (...) Thomas More, cujas heréticas opiniões sobre magnificência são notórias. Este é "More" uma persona que ele criou para seus propósitos complexos - uma persona que de repente adota os valores caros para a "opinião comum": a opinião que acredita que nobreza, magnificência, e o resto são ornamentos de uma república ${ }^{501}$.
}

\footnotetext{
${ }^{500}$ Elliott, Robert. The Shape of Utopia, pg. 47.

${ }^{501}$ Elliott, Robert. The Shape of Utopia, pg. 45-46.
} 
Para Elliott, literalmente "More" faz papel de tolo e Hitlodeu se reafirma como sendo o ponto de vista sensato. Não é a primeira vez que um autor aparece, enquanto personagem, como interlocutor prejudicado. No diálogo Cínico de Luciano, traduzido por More e Erasmo, o interlocutor do Cínico é o próprio Luciano e como "More", ele defende o luxo, as roupas finas, a boa mesa, etc. e leva a pior na discussão. De acordo com Don Cameron, Vanini apresentava filosofias consideradas heréticas nos mínimos detalhes e contradizia com argumentos fracos. No diálogo De Voluptate, Lorenzo Valla utilizou este mesmo artifício.

O De Voluptate, ou, como primeiro foi chamado, De Vero Bono é um diálogo romano entre Leonardo Bruni, Antônio Panormita e Niccolo Niccoli, que representam respectivamente as filosofias éticas estoica, epicurista e a cristã. Bruni fala primeiro e seu estoicismo é uma síntese do que os padres já vinham dizendo há uns mil anos. Então, o epicurista Panormita discursa e ele fala por Valla. (...) Na conclusão dos reparos de Panormita, Niccoli fala em defesa da ética cristã e, é claro, recebe o prêmio, mas é obviamente um prêmio irônico. Ataques subsequentes contra Valla feitos por Poggio e Melanchton indica que todos tinham entendido isso. ${ }^{502}$

No seu estudo sobre a Utopia, Hexter chega a aproximar as duas objeções de "More" ao comunismo para demonstrar o despropósito daquelas que ele expressa no final do livro. ${ }^{503}$

a) Primeiro Hexter apresenta as objeções consideradas mais fracas, que ocorreram a "More" após o relato de Hitlodeu:

Sua vida comum e a subsistência sem nenhuma troca de dinheiro, que é o principal fundamento de todas as suas instituições, derribam toda a excelência, magnificência,

\footnotetext{
${ }^{502}$ Allen, Cameron Don. "The Rehabilitation of Epicurus and His Theory of Pleasure in the Early Renaissance", pg. 10.

${ }^{503}$ Hexter, J.H. More's Utopia: the biography of an idea, 35-36.
} 
esplendor, e majestade - verdadeiros ornamentos e honra da República, conforme a opinião comum. ${ }^{504}$

b) Em seguida Hexter mostra os questionamentos que a persona More apresenta a Hitlodeu imediatamente antes do relato de viagem:

Ora, a mim, contrapus eu, parece-me o contrário: nunca se pode viver bem se tudo estiver em regime de colectividade. De facto, como é que se garante a acumulação de bens em abundância, se cada um se esquiva ao trabalho? É isso mesmo o que é de esperar, uma vez que não há razão para urgir o cuidado dos seus interesses e uma vez que fiar-se no trabalho dos outros conduz à preguiça. Ao invés, se os indivíduos são espicaçados pela miséria, mesmo aquilo que alguém tiver conseguido só será possível pô-lo a salvo como seu se houver alguma lei para isso. Ou será que não se cairia necessariamente em assassínios e sublevações que se perpetuariam? Eliminada sobretudo a autoridade e o respeito devido aos magistrados, quem haveria que atribuísse a alguém um lugar numa sociedade em que não houvesse qualquer distinção? Não consigo sequer imaginá-10 ${ }^{505}$.

Interessante notar que as questões postas antes do relato são mais pertinentes e ponderadas e estão muito próximas das objeções que Aristóteles apresenta no livro II da Política, à comunidade de bens. A ironia disto tudo é que estas dificuldades (indivíduos espicaçados pela miséria, preguiça, roubo assassínios, etc.) foram resolvidas pelas instituições de Utopia, mas não pelas instituições da Inglaterra e do restante da Europa $^{506}$. Já o argumento que aparece depois do relato de viagem é fraco e até mesmo frívolo em comparação com os questionamentos anteriores. Além da fraqueza do argumento da persona More no final do livro II, há ainda motivos adicionais para se afirmar que o autor da Utopia concorda com Hitlodeu. Para isso é preciso que nos voltemos uma vez mais à sua relação com Erasmo, à defesa que ambos fazem do necessário retorno às fontes e aos Pais da Igreja para a recuperação do verdadeiro

\footnotetext{
${ }^{504}$ Utopia, pg. 244; Vtopia, pg. 415(tradução modificada).

${ }^{505}$ Utopia, pg. 106; Vtopia, pg. 284-285.

${ }^{506}$ Hexter, More's Utopia: the biography of an idea, pg. 40-41.
} 
espírito cristão das comunidades primitivas e aos apelos à virtude e aos ideais de verdadeira nobreza. David Wooton no seu artigo "Friendship Portrayed: A New Account of Utopia" desvia da rota costumeira e busca nos Adagiorum Chiliades as raízes de algumas das características de Utopia. Os Adágios são basicamente seleções e comentários de provérbios, frases lapidares e fragmentos. No prefácio, Erasmo justifica a reunião destas frases e fragmentos recorrendo a Aristóteles, segundo o qual os "provérbios eram simplesmente os vestígios de filosofias mais antigas que foram destruídas pelas calamidades da história humana" e que foram preservados "em parte por causa de sua brevidade e concisão e em parte por seu bom humor"; são centelhas dos esforços daqueles que buscaram a verdade antes de nós. Entretanto, o que, na defesa de Erasmo, chama a atenção de Wooton é o seguinte trecho que ele destaca em seu artigo:

Qualquer um que profunda e diligentemente considera o reparo de Pitágoras, 'Entre amigos tudo é comum' certamente encontrará toda a felicidade humana incluída neste breve ditado (saying). Qual é o propósito de Platão em tantos volumes senão a comunidade dos meios de vida, e o fator que a cria, nomeadamente a amizade? Se ele pudesse persuadir os mortais destas coisas, guerra, inveja e fraude desapareceriam de uma vez de nosso meio; em resumo todo um regimento de aflições partiria da vida de uma vez por todas. Qual outro propósito teve Cristo, o príncipe da nossa religião? Um preceito e um único ele deu ao mundo, e era o amor; nele apenas, ensinou Cristo, se assenta toda a lei e os profetas. Ora, o que mais o amor ensina, exceto que todas as coisas deveriam ser em comum? De fato, aquela unidade na amizade com Cristo... como membros de uma cabeça e como um e mesmo corpo, nós podemos ser preenchidos com o mesmo espírito, e chorarmos e nos rejubilarmos juntos com as mesmas coisas. Este é o significado para nós do pão místico, obtido pela reunião de muitos grãos em uma farinha, e do vinho que resulta da fusão em um único líquido de muitos cachos de $u^{507}$.

\footnotetext{
${ }^{507}$ Desiderius Erasmus, Collected Works, vol. 31, trans. Margaret Mann Phillips, ed. R. A. B. Mynors, Toronto: University of Toronto Press, 1982. Apud: Wootton, "Friendship Portrayed: A New Account of Utopia", pg. 32-33
} 
Ainda mais significativas são as escolhas de Erasmo para iniciar seus Adágios. De fato, elas nos surpreendem, como surpreenderam Wooton, que de repente se viu na rota para Utopia. O primeiro adágio é justamente a já mencionada frase atribuída a Pitágoras "entre amigos tudo é comum" e, acrescenta Erasmo, "se apenas ele estivesse tão fixado na mente dos homens, quanto é frequente nos lábios de todos, a maior parte dos males de nossas vidas seria prontamente removida”. Mas não somente Pitágoras, como também Platão havia tentado "mostrar que a condição mais feliz da sociedade [felicissimum reipublicae statum] consiste na comunidade de todas as posses". Erasmo afirma ainda que, ao aplicar este princípio, Pitágoras teria realizado os valores da comunidade de Cristo antes mesmo de Cristo.

Se o primeiro adágio associa a amizade à comunidade de bens, o segundo a identifica à igualdade, outro tema caro à Utopia: “Amizade é igualdade. Um amigo é outro eu”. Esta máxima pitagórica é também compartilhada por Platão, que no livro VI das Leis afirma que “a igualdade é um fazedor de amigos” e também por Cristo: "Qual doutrina produzida pelos filósofos foi mais salutar como um princípio de vida ou mais próxima a religião cristã?”. Pois, lembra Erasmo, “a lei dos hebreus não difere disso, quando nos ensinou a amar o próximo como a nós mesmos" ${ }^{\text {,508 }}$. Máxima também evocada na filosofia moral utopiana.

Ora, afirmar que "a amizade é igualdade" e, ao mesmo tempo, que "os amigos têm todas as coisas em comum" significa estabelecer uma base concreta, material, para esta amizade e confere um sentido à igualdade para além dos termos simbólicos e abstratos, em que ela normalmente é posta. Amizade é compartilhamento de um modo de vida, uma espécie de irmandade, que derruba as distinções entre o meu e o teu.

\footnotetext{
${ }^{508}$ Wootton, "Friendship Portrayed: A New Account of Utopia", pg. 32-33
} 
Complementar a esta afirmação é o elogio do trabalho e a crítica ao parasitismo e à ostentação, que rompem com a igualdade e impossibilitam os laços de amizade.

Por este percurso é possível verificar que a defesa da comunidade de bens não era incompatível com o humanismo cristão. De modo que - embora a obra Utopia tenha certa independência com relação às convicções de seu autor e a sua importância simbólica tenha ultrapassado o próprio humanismo erasmiano - estamos dispensados de supor que como cristão More não poderia estar de acordo com a comunidade de bens. Erasmo, em cartas trocadas com More e outros humanistas, expressou sua concordância com o conteúdo de Utopia, como uma obra que mostra, de uma maneira agradável, as causas dos males da república, assim como a sua solução. Além disso, há bons motivos para se pensar que Erasmo teve participação ativa na elaboração da obra e não apenas na sua edição ${ }^{509}$. Com isso, podemos reinterpretar a carta de Guillaume Budé, incluída com destaque nas edições de Utopia ${ }^{510}$.

Budé refere-se à Utopia como Hagiópolis ou cidade sagrada. Alguns comentadores entenderam esta referência como irônica, enquanto que outros (como vimos na Introdução, este é o caso de George Logan) simplesmente atribuíram-na a um erro de interpretação. Não há que se negar que algumas das cartas são plenas de humor, como vimos na pergunta de More a Giles sobre a localização de Utopia, ou na resposta indireta de Giles na carta a Busleiden, sem falar no jogo de referências cruzadas em outra carta a Giles, em que More brinca com a hipótese da existência real da Utopia. A carta de Budé parece entrar neste jogo de ambiguidades. Ora, se as obras dos filósofos pagãos podem conter verdades cristãs, Utopia, uma cidade pagã, pode, de modo mitigado, com uma piscada de olho, por certo, ser a verdadeira Hagiópolis. Embora esta

\footnotetext{
${ }^{509}$ A esse respeito verificar Hexter, More's Utopia: the biography of an idea, pgs. 99-102.

${ }^{510}$ Neste trecho remeto ao já mencionado artigo de Wooton, especialmente as páginas 35 a 37
} 
designação não deva ser tomada ao pé da letra, no caso da comunidade de bens Utopia é Hagiópolis de todo o direito, como o eram as comunidades pitagóricas.

Assim, não cabe a interpretação de autores como Sylvester, Neumman ou Wooden, no sentido de que Hitlodeu seria o alvo da sátira. Não somente porque ele é o personagem que tem as melhores e mais longas falas, como destacam Robert Elliot, Hexter e Yohan, mas também porque não se sustenta a ideia de que Hitlodeu representaria um filósofo escolástico ou de que as suas propostas são delirantes e viciosas, como querem Sylvester e Neumann. Quanto a Surtz, embora ele não seja tão duro com nosso personagem, insiste ainda assim em que a discordância expressa por "More” no final do livro é a opinião do próprio autor.

Entretanto, há mais uma volta que precisa ser dada neste parafuso. Hexter demonstra sem ambiguidades que, na sua forma original, Utopia não previa a inclusão de diálogo algum. Isto significa que o relato de viagem se iniciaria logo depois da apresentação de Hitlodeu por Peter Giles e terminaria com a peroração. Não havia, portanto, qualquer crítica do personagem More a Hitlodeu. Também não havia qualquer discussão sobre a participação do filósofo no conselho de reis ou mesmo o relato sobre o diálogo na mesa do cardeal.

Esta descoberta afasta a ideia de que a obra foi escrita tendo Hitlodeu como uma figura ridícula, já que ele é descrito como um filósofo na introdução, e no relato ele praticamente desaparece. Também fica problematizada a interpretação de Surtz. Mas, por que motivo o diálogo teria sido posteriormente incluído, ex tempore, como a ele se referiu Erasmo? Esta questão também foi colocada por Hexter. E a sua posição é a de que não há dados que possam assegurar uma resposta definitiva ${ }^{511}$. Entretanto, Hexter

${ }^{511}$ Hexter, More's Utopia: the biography of an idea, pg. 99. 
não deixa de responder à questão. Ocorre que coincidentemente, no período entre a missão em Bruges e a volta para Londres, More foi chamado por Henrique VIII para fazer parte de seu conselho na corte, e o diálogo do conselho representaria o seu próprio dilema pessoal: "foram a oferta do rei e as dificuldades de sua própria situação que em primeiro lugar forçaram More a considerar o problema do conselho. (...) Já na primeira página do Diálogo do Conselho, no que pode ser uma recapitulação do seu próprio processo de pensamento, More apresenta os motivos do lucro, da honra e do poder como bases para se entrar para o serviço de um príncipe, apenas para afastá-los de uma vez por todas." ${ }^{, 512}$

Esta leitura também torna difícil interpretar a obra como satírica, uma vez que a estrutura original nada tinha a ver com aquela identificada por Elliott. É ainda possível argumentar neste caso particular que a configuração final da obra, independente de qual tenha sido a intenção original do autor, acabou sendo satírica. Entretanto, esta interpretação não dá conta da obra completa, e por isso acaba tendo que se alicerçar no diálogo do livro I. Elliott é obrigado a admitir que o livro II foge um tanto da estrutura, pois que, exceto por umas referências esparsas, como os anemólios, a contraparte viciosa está ausente. Ainda que considerássemos toda a obra, a parte que descreve Utopia seria preponderante com relação à parte crítica, que só de maneira muito forçada, seria representada pelo livro I na sua inteireza. De forma que Utopia não se coaduna com as sátiras versificadas de Horácio ou Juvenal, exceto por uma ou outra citação. Críticos mais recentes a aproximam das sátiras menipeias, em prosa, mais precisamente as de Luciano, que, diferente da versificada, comportariam outras estruturas, como as viagens. Entretanto, diferente do que ocorre nas sátiras de Luciano, não há qualquer história no livro II que pudesse lembrar uma viagem menipeia. Não há

\footnotetext{
${ }^{512}$ Hexter, More's Utopia: the biography of an idea, pg. 113.
} 
histórias em Utopia. Não há nem sombra do relato saboroso de um Menipo descendo ao inferno, nenhum balançar irônico de cabeça para os debates dos filósofos e nenhum personagem extravagante que acompanhasse Hitlodeu. Mas o mais importante é que não há nenhuma regra de conduta para ser extraída da viagem de nosso marinheiro. O relato é tão somente uma discussão sobre as instituições políticas. Ainda que consideremos a moral utopiana, em grande medida a sua aplicação depende da sua organização social. É inegável, entretanto, que a obra possui aspectos satíricos: nos nomes dos lugares e povos, na figura de Hitlodeu que ecoa em parte a persona satírica do cínico de Luciano, na altercação do tolo com o frade, e também na maneira de composição dos diálogos. Mas ela resiste a ser subsumida inteiramente ao gênero, ainda que consideremos sátira como serio ludere.

George Logan afasta a interpretação satírica como sendo inadequada. Para ele, a chave para compreender o personagem Hitlodeu deve ser procurada em outro lugar, mais precisamente nos diálogos de Platão. Segundo esta interpretação, o personagem é concebido segundo os moldes dos porta-vozes de Platão dos diálogos o Sofista, o Político e as Leis, todos eles estrangeiros que dominam os diálogos. Em nota ele comenta que "é então enganador descrever Hitlodeu como 'uma versão de uma persona satírica convencional: um missionário que retorna de uma jornada por lugares estranhos para relatar a verdade sem enfeites sobre a sociedade, a corte, o clero, a época",513, como o faz Heiserman.

Para ele também a obra se divide basicamente em duas partes: a primeira cujo tema é a Europa e a segunda cujo tema é a Utopia. Por um lado os problemas estruturais da Europa, juntamente com um método de abordagem; por outro lado, um modelo, não

${ }^{513}$ Logan, The meaning of More's Utopia, pg. 35-36. 
exatamente perfeito, mas com "alguns pequenos absurdos",514. Entretanto, “[q]uando nós vemos a Europa e o modelo da comunidade alternativa justapostos nesta visão panorâmica, os benefícios de uma sociedade racional e planejada são claros"515 .

Como um teórico político da polis ideal, More traça, a partir das discussões de Platão e Aristóteles, o modelo da melhor república possível, fundado no conceito de autossuficiência. Como More pensa a partir do enquadramento fornecido pela teoria política grega, a sua república ideal é uma polis e não uma comunidade cristã universal como propunha o humanismo erasmiano. Neste sentido, ela seria então uma espécie de protótipo a ser exposto ao escrutínio de seus pares, a comunidade de humanistas.

O livro II provê uma espécie de modelo de aplicação abrangente de uma abordagem sistemática para a ordenação da sociedade e no processo sugere que, a despeito da afirmação dos estoicos de que o útil sempre se harmoniza com o bom, soluções inteiramente satisfatória podem não ser possíveis, ainda que teoricamente: parece haver um inescapável cálculo de compensações entre os requisitos para assegurar a república, a liberdade para seus habitantes e a justiça para com os povos vizinhos. Então, as características não atrativas da Utopia significam aspetos cruciais das conclusões de More $^{516}$.

Mas, segundo Logan, a Utopia, também é uma obra crítica dirigida basicamente a dois públicos: os humanistas cristãos e os adeptos da política prática. Para os humanistas cristãos, em primeiro lugar, a Utopia demonstraria as insuficiências de uma abordagem meramente moral das questões políticas, tornando evidente a inanidade dos espelhos de príncipe. Em segundo lugar, ela procuraria mostrar que os problemas enfrentados pelas repúblicas são estruturais, cujas causas podem estar distantes dos efeitos, sendo que a solução passa necessariamente por um reequacionamento da questão em termos mais amplos. Para os adeptos da política prática e das tendências

\footnotetext{
${ }^{514}$ Utopia, pg. 249

${ }^{515}$ Logan, The meaning of More's Utopia, pg 251.

${ }^{516}$ Logan, The meaning of Utopia's More, pg 258.
} 
seculares da teoria humanista, "esta crítica toma a forma de mostrar que os ditames da prudência, ainda que não inteiramente idênticos aos da moralidade, não diferem tanto deles como os teóricos seculares imaginam"517. Entretanto, para Yoran,

George Logan sistematicamente elabora o que é talvez a solução mais senso comum para as contradições de Utopia. Como os neo-católicos, Logan toma o adjetivo optimus no título da obra como significando não "ideal" ou "perfeito", mas "o melhor". Ele argumenta que o que "o melhor" realmente significa é o melhor possível dadas algumas razoáveis suposições sobre a realidade externa e a natureza humana e conclui que as práticas e instituições pouco atraentes descritas na Utopia são simplesmente o preço que More se sente obrigado a pagar para realizar objetivos mais importantes ${ }^{518}$.

Yoran caracteriza então a república ideal de More como o resultado mais completo da República das Letras. Para ele, "mais do que qualquer outro trabalho, Utopia, e, de fato, a invenção do gênero utópico, atesta a identidade do intelectual universal construído pelo humanismo erasmiano"519. A polis ideal de More é abstrata e desencarnada como a República das Letras. Não é por acaso que o fictício e o real têm o mesmo direito de cidadania dentro da obra e remetem um ao outro sem cessar. É a própria expressão da contradição do erasmianismo que abraça os valores humanistas, mas rejeita na prática o vivere civile. $\mathrm{O}$ resultado, segundo ele, é um universalismo abstrato alicerçado numa ideia vaga de uma comunidade cristã universal, assemelhada no modo de vida às primeiras comunidades cristãs. Mas, para Yoran, não temos uma completa compreensão da Utopia se não compreendermos que nela há dois níveis de discurso: o aparente, que provê a visão da cidade ideal, e o mais profundo, que seria distópico. Mas, segundo Yoran, estes dois níveis nada têm a ver com as intenções do autor.

\footnotetext{
${ }^{517}$ Logan, The meaning of Utopia's More, pg 258.

${ }^{518}$ Yoran, Between utopia and dystopia, 173.

${ }^{519}$ Yoran, Between utopia and dystopia, 159.
} 
Para compreendermos o que Yoran quer dizer, é preciso retornar alguns passos. Para ele, o humanismo é basicamente uma forma, uma atitude perante o mundo. O humanista valoriza a gramática e a retórica porque a sua atividade seria basicamente a produção de significado ${ }^{520}$. Segundo ele, a Utopia, no seu nível mais profundo, impede esta produção de significado. Para demonstrar isso, recorre aos traços que considera distópicos na obra. Ele se pergunta, por exemplo, por que cidadãos que chegaram ao mais alto grau de civilização não têm liberdade para escolher a sua cor de roupa ou sentar à mesa no lugar que desejarem, ou ainda se sujeitam a uma supervisão sem limites? "Por que estas pessoas simplesmente não enterram os suicidas fora do chão consagrado, ao invés de atirar os seus corpos no pântano? Por que estas pessoas se regozijam com a morte dos Zapoletas, seus melhores mercenários?",521

Para responder a estas perguntas, Yoran buscará ainda outros elementos no interior da Utopia que lhe permitirão reunir as condições necessárias para melhor caracterizar a república ideal de More. Para ele, é significativo que na cidade humanista estejam ausentes as disciplinas tão caras a More e a Erasmo: a gramática e a retórica.

Hitlodeu nos garante que eles "estudam todos os ramos do conhecimento". Conforme ele dá mais detalhes, entretanto, uma imagem diferente emerge. "Em música, dialética, aritmética e geometria eles descobriram mais ou menos as mesmas coisas que nossos grandes homens do passado", diz ele, e menciona também seus grandes conhecimentos em astronomia. As disciplinas humanistas não merecem menção como um grupo distinto, e das sete artes liberais os acadêmicos utopianos estudam apenas as cinco dialética, aritmética, geometria, música e astronomia - que tradicionalmente pertenciam à esfera escolástica e ignoram as duas distintamente humanistas, gramática e retórica. Os acadêmicos do Estado ideal humanista, resolutos na busca do progresso do aprendizado e da educação, desconsideram os studia humanitatis.

O motivo dessa ausência estaria na restrição dos espaços de dissensão, os quais permitiriam a produção de significação. Utopia, ao contrário, seria constituída de

\footnotetext{
${ }^{520}$ Yoran, Between utopia and dystopia, 30.

${ }^{521}$ Yoran, Between utopia and dystopia, pg.174.
} 
maneira que esta produção de significação é controlada ou inibida, fazendo com que resvalasse na distopia.

Cabe, porém, perguntar até que ponto está correta esta leitura feita por Yoran. E a resposta a esta questão exige que examinemos rapidamente um artigo que aborda a relação entre o humanismo do norte e o humanismo cívico italiano. Como vimos, o humanismo apresenta variações e diferenciações internas, e Thomas More é crítico de alguns valores adotados por outros humanistas - e não somente do vivere civile do humanismo italiano especificamente, mas também de toda uma concepção de justiça e glória própria da tradição romana recuperada pelos humanistas da Itália. Eric Nelson, no seu artigo "Utopia through Italian Eyes: Thomas More and the Critics of Civic Humanism", mostra como Bodin já reconhecia na Utopia sua filiação à tradição grega (colocando-a ao lado da República de Platão e da Política de Aristóteles) em oposição à tradição romana. De fato, o modo como Bodin apresenta as duas tradições (um insight que, segundo Nelson, deve ser levado a sério) no livro 5 da sua obra Seis livros da República é bastante significativo. É neste livro que é tratada questão das revoluções e das sedições, cuja principal causa é a desigualdade. Em seu enquadramento da questão, Bodin considera que duas tradições republicanas, no âmbito da teoria política, estavam postas: a grega e a romana.

Na tradição grega a justiça é a organização social de acordo com a razão em vista da eudaimonia ou felicidade, objetivo da pólis. Em vista deste objetivo, a boa organização da cidade determina que todos os elementos ocupem o lugar devido e, por conta disso, prevê uma distribuição equitativa de bens, como em Aristóteles, ou mesmo sua posse em comum, como em Platão. É a melhor forma da república que possibilita o 
pleno desenvolvimento da autarquia, em que as paixões e dissensões possam ser postas sobre o controle da razão e é nisto que reside a verdadeira liberdade.

Na tradição romana, por outro lado, a justiça formulada no Digesto é dar a cada um o que é seu (ius suum) e tem um sentido jurídico de garantia da propriedade. Nesta forma de compreensão da justiça, a confiança mútua e a garantia dos contratos, inclusive no caso das dívidas, são basilares para a república. De modo que a defesa da comunidade de bens e do perdão de dívidas é compreendida como um ataque aos fundamentos da própria república. O homem livre, entendido como aquele que não está sob o arbítrio de outrem ${ }^{522}$, sendo, portanto, mestre de sua própria vontade, seria também, nesta concepção romana, quem reúne as condições para o exercício da virtude cívica (a dedicação desinteressada ao bem público) e quem tem o dever de garantir a justiça e a concórdia necessárias para alcançar o verdadeiro objetivo da república - a glória.

Vimos como More põe na boca de Hitlodeu a defesa da comunidade de bens, e como Erasmo nos Adágios aproxima, por meio dela, os ensinamentos de Platão aos de Cristo, bem como as comunidades pitagóricas e as primeiras comunidades cristãs. Vimos também que na carta a Lupset, incluída entre as cartas dos humanistas que servem de prefácio à Utopia, Budê identifica a cidade ideal de More à comunidade estabelecida por Cristo, pitagórica a seu juízo. Referindo-se à situação oposta, então reinante na Europa, diz Hilodeu:

É por isso que quando eu olho para todos os Estados que hoje se apresentam em prosperidade, dou comigo a pensar (...) se não está a ocorrer uma conspiração de ricos que usurpam o nome e a autoridade do Estado para tratarem dos próprios interesses, congeminando e maquinando todos os modos e todas as estratégias para, primeiro, ficarem com os bens que desonestamente açambarcaram, sem medo de os perderem, depois, para pagarem o mínimo possível de mão-de-obra aos pobres e para deles

${ }^{522}$ Cf. Skinner, Quentin. Liberdade antes do liberalismo. 
abusarem. Estas maquinações, desde que alguma vez os ricos as promulguem em nome do bem público, isto é, em nome também dos pobres, logo se tornam leis. ${ }^{523}$

A posição não pode ser mais clara. A fala distancia o personagem da justiça romana, identificada aqui aos Estados prósperos (através das maquinações dos ricos que apresentam sua acumulação de propriedades como uma contribuição para o bem público), e coloca em igual distância Utopia, que instituiu a verdadeira justiça. Ademais, a defesa da tradição grega está presente na Utopia tanto na construção do próprio Hitlodeu (que se assemelha a Platão, conhece mais grego do que latim, pois considera que os latinos têm pouco a contribuir e por isso preferiu levar os escritos dos gregos para Utopia) quanto na caracterização da Utopia (a qual rivaliza com a República de Platão, além de ter um alfabeto que se assemelha ao grego). Além disso, More chega mesmo a dizer, quase nos termos de Hitlodeu, numa de suas cartas ditas humanistas (a carta ao monge John Batmanson), que no que tange àquelas "artes que chamam liberais, juntamente com a filosofia, no que concerne a seus objetos os latinos não escreveram quase nada" ${ }^{524}$. De forma que More e sua Utopia colocam-se firmemente no lado grego do espectro político, como já fora notado por Bodin. Mas não apenas por este último, como mostra Nelson - de modo mais significativo, esta também era a consideração feita tanto pelos humanistas cívicos italianos quanto por seus opositores, os chamados anticiceronianos, ambos reconhecendo no humanismo de More (e Erasmo) uma crítica de inspiração grega ao humanismo cívico de herança latina.

Dito isso, se a comunidade utopiana de bens está em oposição direta à romanitas no que respeita à justiça, algo de semelhante pode ser dito da crítica ao orgulho - este prazer adulterado que se deleita com honrarias inúteis, com os joelhos que se curvam ou

\footnotetext{
${ }^{523}$ Utopia, pg. 240; Vtopia, pg. 412.

${ }^{524}$ More, Complete works of St. Thomas More, vol. 15, pg. 220
} 
com títulos nobiliários de uma longa estirpe, cuja felicidade "ganha brilho apenas quando desdobra as suas riquezas perante as misérias dos outros" ${ }^{\text {,525 }}$. Como identificou a personagem More no final do livro: "sem qualquer forma de comércio com dinheiro (disso se trata), cai por terra toda a nobreza, a magnificência, o esplendor, a majestade, que, como sustenta a opinião pública, é a verdadeira beleza e ornamento da República" (decora atque ornamenta Reipublicae). ${ }^{526}$ Mas o filósofo justamente se afasta da opinião pública (tida como loucura por Hitlodeu, por Platão e também por Erasmo) e por isso mesmo não se coaduna com a vida prática no Estado corrompido. Por este motivo a Loucura, no elogio que faz de si própria, não deixa de destacar o quão inútil é a sabedoria dos filósofos num mundo em que ela, a loucura, domina a maioria.

Do quão inúteis os filósofos são para todas as necessidades da vida prática, pode servir de prova o próprio Sócrates, julgado, ainda que de forma muito pouco sábia, como um sábio único pelo oráculo de Apolo, mas que, quando tentou falar em público de não sei que questão, teve de desistir, em meio ao riso geral de todos. Ainda que não tenha perdido de todo o senso comum perante os homens, pois não aceitou o epíteto de sábio, mas antes o devolveu à própria divindade, e também porque julgava que o sábio deveria abster-se de tratar da República; mas deveria é ter aconselhado que aquele que quiser ser incluído no cômputo dos homens deve tomar distância da sabedoria. ${ }^{527}$

E em acordo com a posição de Hitlodeu, completa o humanista, sob a máscara da loucura, que o filósofo "não pode jamais ser útil nem para si mesmo, nem para a pátria, nem para os seus porque, além do mais, é inexperiente nas coisas mais comuns e, larga e amplamente está em discrepância com a opinião popular e com aquilo que foi decidido por todos" ${ }^{, 528}$. Os que não discrepam desta opinião e, pelo contrário, buscamna, são justamente aqueles que, a exemplo de Cúrcio e dos Décios, cometem os maiores atos de loucura em nome da glória:

\footnotetext{
${ }^{525}$ Utopia, pg. 242; Vtopia, pg. 414.

${ }^{526}$ Utopia, pg. 244; Vtopia, pg. 415.(tradução modificada)

${ }^{527}$ Erasmo, Elogio da loucura, pg. 69.

${ }^{528}$ Erasmo, Elogio da loucura, pg. 72.
} 
Por outro lado, que Estado adotou alguma vez as leis de Platão ou de Aristóteles, ou as doutrinas de Sócrates? Mas então, que foi que persuadiu os Décios a oferecer-se espontaneamente em sacrifício aos deuses manes? Que foi que atraiu Cúrcio ao abismo senão a vã glória, esta espécie de dulcíssima sereia, que é, no entanto, tão condenada pelos filósofos? Dizem eles: "pois que há de mais estúpido que um candidato suplicante que bajula o povo, compra o favor deste mediante donativos, caça os aplausos de tantos estúpidos, se compraz com suas aclamações, se deixa carregar em triunfo, como alguma espécie de símbolo para espetáculo do povo e que vira estátua de bronze no foro? Acrescenta a isso a adoção de nomes e apelidos. Acrescenta as honras divinas, tributadas a algum homúnculo. Acrescenta o fato de que mesmo os tiranos mais criminosos são alçados a deuses em cerimônias públicas. Grandes loucuras são essas coisas, e tais que um Demócrito só não bastaria para rir-se delas" ${ }^{\$ 29}$.

É significativo que as filosofias de Platão e Aristóteles sejam contrastadas com glória romana (ou "vã glória", nos termos de Erasmo), um tipo de loucura diante da qual a resposta adequada seria o riso demolidor de Demócrito. Também são significativos os termos em que o orgulho é descrito e criticado por Hitlodeu, os quais talvez nos permitam ver aqui o orgulho como uma tradução cristã da glória romana. Afinal, More não se deparava com patrícios romanos em busca de glória, e sim com nobres europeus orgulhosamente aparamentados.

Ora, o critério pelo qual se pauta o filósofo (e, por conseguinte, a república ideal por ele governada) é a razão e não a inconstante opinião comum. Como sabemos, Utopia é governada pelos acadêmicos. Sabemos também que se tornam acadêmicos somente aqueles que se destacam nas artes liberais, e que estas últimas incluem a filosofia moral. Além disso, a república é organizada de modo a livrar o máximo possível todos os cidadãos da servidão do corpo para que possam se dedicar ao cultivo das artes, o que faz com que todos eles sejam virtualmente filósofos, ou que ao menos tenham alguma participação na sabedoria.

\footnotetext{
${ }^{529}$ Erasmo, Elogio da loucura, pg. 72.
} 
Assim, se a Utopia se filia a tradição grega e expressa uma crítica da romanitas, opondo-se em certa medida ao humanismo cívico das cidades italianas, então, como demonstra Nelson, o republicanismo do humanismo do norte não pode ser visto como uma mera continuação do que se produziu na Itália. E isso significa que, por esta via, talvez possamos encontrar algumas respostas para ao menos uma parte das contundentes críticas de Yoran. Ora, se a concórdia na filosofia política grega é obtida pela organização mais justa de acordo com a razão, podemos supor que aquilo que Yoran viu como sinais de distopia, como, por exemplo, o uso de hábitos monásticos, seria apenas o resultado da decisão mais racional. Porém, há ainda alguns reparos a se fazer. Yoran estranha a ausência das artes liberais no relato de Hitlodeu ou, entre outras coisas, o fato de que pessoas com o mais alto grau de conhecimento não possam escolher as próprias roupas e atribui a isso uma tentativa de controle da dissensão pelo controle da significação. $\mathrm{Na}$ verdade, em nenhum momento Hitlodeu afirma que as pessoas não podem escolher as próprias roupas ou que exista alguma imposição neste sentido. Antes, More parece ter construído para Hitlodeu um olhar quase etnográfico. Pois em seu relato ele simplesmente registra a indumentária dos utopianos tal como um etnógrafo registraria os usos e costumes de povos distantes e tão diferentes de nós que se surpreendem "que haja alguém que seja tão insano que julgue o grau de nobreza pela delicadeza do fio de lã”.

Hitlodeu se refere às roupas em dois momentos. A primeira menção é no contexto da descrição das artes e ofícios a que se dedicam os utopianos.

De facto, quanto à roupa, se exceptuarmos as diferenças de vestuário para homens e para mulheres ou para solteiros e para casados, a forma é única para toda a ilha e é idêntica sempre ao longo dos tempos; o corte não é deselegante à vista e é ajustado ao 
movimento do corpo, tão conveniente para o frio como para o calor. É em família que se confeccionam todas as peças. ${ }^{530}$

A segunda menção ocorre em meio à descrição da racionalidade da economia utopiana, a qual inclui estratagemas para poupar as pessoas do trabalho manual.

Um outro factor de economia é de mencionar: na maior parte dos mesteres que produzem bens indispensáveis, há menos trabalho a executar que noutros povos. (...) Quanto ao vestuário, veja-se como necessitam de pouca mão-de-obra: antes de mais nada, quando andam a trabalhar, envolvem-se numas peças de couro ou em peles sem grande apuro, as quais lhes duram uns sete anos; quando saem a público, põem por cima um manto, que lhes serve para encobrir aquelas peças mais grosseiras, e cuja cor é única por toda a ilha e tem a cor natural do tecido. Assim, aqui não só se gasta menos em tecido de lã do que em qualquer outra parte, como também esse tecido lhes fica mais barato. Quanto ao linho, ele reclama menos trabalho e por isso o seu uso é mais frequente; mesmo assim, no linho só atendem ao candor, na lã apenas olham o asseio, não levando em conta a delicadeza do fio. ${ }^{531}$

No que respeita às artes liberais, embora Hitlodeu não tenha nomeado diretamente a gramática e a retórica quando se referiu a algumas das disciplinas a que os utopianos se dedicavam, a formulação do trecho não parece indicar que se trate de uma lista completa ou exaustiva. Por outro lado, é possível supor que os utopianos estudem gramática, afinal eles têm uma língua que é próxima do grego e dominam a escrita. Mas o que se tem em vista com este conjunto de estudos é a educação do cidadão e do filósofo de acordo com a razão, pois, como relata Hitlodeu em outro momento:

Estas opiniões e outras semelhantes receberam-nas eles, em parte, por educação (formados que foram numa organização em que as instituições estão bem longe de tais gêneros de estultices ${ }^{532}$ ), e em parte por reflexão e por leitura nos livros. De facto, mesmo que não haja muitos que sejam dispensados do trabalho físico para se dedicarem apenas à reflexão (como são os que desde os primeiros anos de vida são reconhecidos como sendo dotados de nobreza de carácter e de inteligência superior além de terem

\footnotetext{
${ }^{530}$ Utopia, pg. 126; Vtopia, pg. 302.

${ }^{531}$ Utopia, pg.132-134; Vtopia, pg. 307-308.

532 As estultices são, além da valorização do homem pela roupa, o amor pelo ouro e a disposição de se deixar dominar por outro unicamente em virtude da fortuna que este último amealhou ao longo da vida.
} 
inclinação para as artes liberais), mesmo assim, todas as crianças são iniciadas nas letras, e uma larga percentagem da população, homens e mulheres, ao longo de toda a vida, nas horas que, como dissemos, ficam isentas de trabalho manual, dedicam-se à letras. ${ }^{533}$

Por certo a Utopia é o resultado da República das Letras e a suas contradições expressam as contradições reais do intelectual universal que opta por realizar a crítica radical e que se recusa a aceitar menos do que aquilo que as coisas deveriam ser: a contradição fundamental de estar no mundo, mas agir em nome de outro mundo. Utopia é nada mais nada menos do que o nosso outro radical e ao mesmo tempo imagem do que deveríamos ser, de acordo com um humanista cristão erasmiano. Daí seu traço formal mais destacado, a passagem constante da realidade para a ficção e vice-versa. Segundo Eric Nelson, esta característica também estava presente nos herdeiros italianos do humanismo erasmiano, como Ortensio Lando, um polígrafo que assinou alguns de seus trabalhos como "ex Utopia ciuis" ("um cidadão de Utopia”) e que, não por acaso, traduziu Utopia para o italiano, publicando-a com um prefácio de Anton Francesco Doni (o qual viria mais tarde a escrever Il Mondo, sua própria utopia). Nos trabalhos de Lando como no de Doni a figura paradoxal do pazzo como verdadeiro sábio também aparece. ${ }^{534}$ Assim, o que há de irreal em Utopia é a exigência de outro mundo, no caso um mundo que se pareça a um só tempo com a sociedade pitagórica, com a platônica e com Hagiópolis. Por certo que há defeitos na cidade ideal, sobretudo para os homens e mulheres de letras do século XXI: como, por exemplo, a escravidão, a constante vigilância mútua e as limitações para viajar. Mas isto se deve ao fato de Utopia ser obra humana, e também à distância histórica entre o autor e os leitores atuais da obra, mesmo quando estes últimos creem estar fazendo uma leitura objetiva. Embora ela seja

\footnotetext{
${ }_{533}$ Utopia, pg. 158; Vtopia, pg. 302.

${ }^{534}$ Cf. Nelson, "Utopia through Italian Eyes: Thomas More and the critics of Civic Humanism", pgs. 1041-153
} 
expressão da tradição filosófica grega, traz as marcas de concepções cristãs e até mesmo católicas, por exemplo, na desconfiança do caráter pecaminoso do ser humano (o qual torna necessária a vigilância), na ambiguidade da renúncia aos bens materiais, que é a raiz do padrão de vestimenta, nos aspectos de sua filosofia moral, nos elementos do culto utopiano em que se pode identificar o culto dos cartuxos, etc. Mas alguns dos costumes causaram estranhamento até ao filósofo que nos narrou o que viu, pois ela é e não é cristã. Ela é um modelo, como eram os Polileritas, os Macários e os Acorianos, ou mesmo os gregos e romanos (por que não?) para se considere uma reforma da Europa cristã. Cada tempo produz sua própria imagem utópica que inevitavelmente envelhecerá. ${ }^{535}$ Mas os principais elementos do debate presentes no livro que opõem as duas tradições republicanas ainda estão $\operatorname{postos}^{536}$ e o intelectual continua premido a necessidade de participação e a impotência objetiva, entre uma mudança mitigada e a exigência de um inteiramente outro.

\footnotetext{
535 "For in my daydreams I have been marked out by my Utopians to be their king forever; I can see myself now marching along, crowned with a diadem of wheat, very striking in my Franciscan frock, carring a handful of wheat as my sacred scepter, thronged by a distinguished retinue of Amaroutians, and, with this huge entourage, giving audience to foreign ambassadors and sovereigns; wretched creatures they are, in comparison with us, as they stupidly pride themselves on appearing in childish garb and feminine finery, laced with that despicable gold, and ludicrous in their purple and jewels and other empty baubles." Carta 11 "To Erasmo", In: Selected letters, pg. 85.

536 "On the one hand, there was the Roman tradition, which valued independence, private property, and the glory brought by empire; on the other there was the Greek, which valued the rational ordering of the state made possible by the regulation of wealth. The first of these ideologies was the model for all subsequent theories that have preached the sovereignty of the individual in his own sphere; the second was the foundational expression of the view that men must be 'forced to be free'. (...) If the confrontation between these visions remains a central feature of our political lives, then the story of More and the poligrafi is very much a story about today." (Nelson, "Utopia through Italian Eyes: Thomas More and the Critics of Civic Humanism", pg. 1053)
} 


\section{BIBLIOGRAFIA}

ADAMS, R. P. "Designs by More and Erasmus for a New Social Order". Studies in Philology, Vol.42, No.2 (Apr., 1945), pp. 131-145. Disponível em http://www.jstor.org/stable/4172692 (acessado em 02/01/2016)

.The Better Part of Valor: More, Erasmus, Colet, and Vives, on Humanism, War, and Peace, 1496-1535. Seattle: University of Washington Press, 1962. . "The Philosophic Unity of More's 'Utopia'”. Studies in Philology,

Vol. 38, No. 1 (Jan., 1941), pp. 45-65. Disponível em http://www.jstor.org/stable/4172514 (acessado em 17/03/2012).

. "The Social Responsibilities of Science in Utopia, New Atlantis and after". Journal of the History of Ideas, Vol. 10, No. 3 (Jun., 1949), pp. 374-398. Disponível em http://www.jstor.org/stable/2707043 (acessado em 01/06/2016).

ALBORNOZ, Suzana. "Em busca do Éden Eldorado. A utopia de Cristóvão Colombo", in: MORUS - Renascimento e Utopia,n. 7, 2010, p. 86.

ALLEN, Cameron Don. "The Rehabilitation of Epicurus and His Theory of Pleasure in the Early Renaissance”. Studies in Philology, Vol. 41, No. 1 (Jan., 1944), pp. 1-15. Disponível em http://www.jstor.org/stable/4172640 (acessado em 14/06/2015).

ALlEN, J.W. A History of Political Thought in the Sixteenth Century. London: Methuen \& Co LTD, 1957. 
ALLEN, Peter R. "Utopia and European Humanism: The Function of the Prefatory Letters and Verses". In: Studies in the Renaissance, Vol. 10 (1963), pp. 91-107. Disponível em http://www.jstor.org/stable/2857050 (Acessado em 26/10/2015).

AMES, Russel. Citizen Thomas More and His Utopia. Princeton: Princeton University Press, 1949.

ARISTÓTELES. Ethica Nicomachea I 13 - III 8: tratado da virtude moral. Tradução, notas e comentários de Marco Zingano. São Paulo: Odysseus, 2008. . Metafísica (Livro I e Livro II), Ética a Nicômaco e Poética. São Paulo: Abril Cultural, 1984. Coleção Pensadores.

. The Complete Works of Aristotle. Editado por Jonathan Barnes. Princeton: Princeton University Press, 1995. 2 vol.

BRADSHAW, B. Transalpine Humanism. In: BURNS, J. H. e GOLDIE, M. The Cambridge History of Political Thought 1450-1700. Cambridge: Cambridge University press, 2008.

BARON, H. The Crisis of Early Italian Renaissance: Civic Humanism and Republican Liberty in an Age of Classicism and Tyranny. Princenton: Princenton University Press, 1955.

BIGNOTTO, N. Maquiavel republicano. São Paulo: Loyola, 1991.

BLOCH, Ernest. O Princípio da Esperança. Rio de Janeiro: Contraponto, 2006. 3 vols.

BURKE, P. “A República das Letras”. Estudos Avançados 25 (72), 2011.

CASPARI, Fritz. "Erasmus on the Social Functions of Christian Humanism". In: Journal of the History of Ideas, Vol. 8, No. 1 (Jan., 1947), pp. 78-106. Disponível em http://www.jstor.org/stable/2707442 (acessado em 01/06/2016).

CHAMBERS, R. W. Thomas More. Londres: Jonathan Cape, 1935.

CICERO, Marco Túlio. De L’Orateur. Paris: Librairie Garnier,1934. 
On Duties. GRIFFIN, M.T. and ATKINS, E. M. (eds.). New York: Cambridge University Press, 2013.

CLAEYS, Gregory. Utopia: a história de uma ideia. São Paulo: Edições SESC, 2013. and SARGENT, Lyman Tower (eds.). The Utopian Readers. New York/London: The New York University Press, 1999.

DIODORUS SICULUS. Diodorus of Sicily. Trad. C. H. Oldfather, 12 vols. Cambridge: Harvard University Press. London: William Heinemann, 1967.

DOLlimorE, J. Radical Tragedy: Religion, Ideology and Power in the Drama of Shakespeare and his Contemporaries. New York: Palgrave Macmillan, 2004.

DUHAMEL, P. Albert. “Medievalism of More's Utopia”. Studies in Philology, v. 52, n. 2, abr. 1955, p. 99-126. Disponível em http://www.jstor.org/stable/4173125 (acessado em 17/03/2012)

ELLIOT, Robert. The Shape of Utopia, Chicago/London: The University of Chicago Press, 1970.

FERRARI ,G. R. F. (ed). The Cambridge Companion to Plato's Republic, Cambridge: Cambridge University Press, 2007.

FINLEY, Moses. Uso e abuso da história. São Paulo: Martins Fontes, 1989.

FLEISHER, Martin. Radical Reform and Political Persuasion in the Life and Writings of Thomas More, Genève: Librairie Droz, 1973.

FOX, Alistair e GUY, John. Reassessing the Henrician Age: Humanism, Politics and Reform 1500-1550. Oxford: Basil Blackwell, 1986.

FRANCO Jr. As Utopias medievais. São Paulo: Brasiliense,1992.

GARIN, E. Ciência e vida civil no Renascimento italiano. Tradução de Cecília Prado. São Paulo: Editora UNESP, 1996.

GREENBLATT, S. Renaissance Self-fashioning: from More to Shakespeare, Chicago: The University of Chicago Press, 1980. 
HEISERMAN, A. D. "Satire in the Utopia”. PMLA, Vol. 78, No. 3 (Jun., 1963), p. 163174. Disponível em http://www.jstor.org/stable/460858 (acessado em 17/03/2012).

HESÍODO. Os trabalhos e os dias. São Paulo: Iluminuras, 1996. . Trabalhos e dias. Organização, introdução e tradução de Christian Werner. São Paulo: Hedra, 2013. . Teogonia. Estudo e tradução de Jaa Torrano. São Paulo: Iluminuras, 2015.

HEXTER, J. H. More's “Utopia”: The Biography of an Idea. Nova York: Harper Torchbooks, 1965.

HORKHEIMER, M. e ADORNO. T. Dialética do esclarecimento: fragmentos filosóficos. Trad. Guido Antônio de Almeida. Rio de Janeiro: Zahar,1985.

JAMESON, Fredric. "The Politics of Utopia”. New Left Review, 25, jan.-feb., 2004.

KAUTSKY, Karl. Thomas More and his Utopia. Londres: AC Black, 1927.

KINNEY, A. Humanist Poetics: Thought, Rhetoric, and Fiction in Sixteenth-century England. Amherst: University of Massachusetts Press, 1986.

KNOX, Ronald. "The Charge of Religious Intolerance". In: The Fame of Blessed Thomas More, London, 1929, pgs. 43-44.

KRISTELLER, P. O. El pensamiento renascentista e sus fuentes. Tradução de Federico Patán Lópes. Cidade do México: Fondo de Cultura Economica, 1982. . "Thomas More as a Renaissance Humanist". In: Moreana, vol. 17, no. 65-66 (Jun 1980): 5-22.

LEWIS, C. S. English Literature in Sixteenth Century Excluding Drama. Oxford: Clarendon Press, 1954.

LOGAN, George. The Meaning of More's Utopia. Princeton: Princeton University Press, 1983. 
LUCIANO DE SAMÓSATA. Saturnalia, in Lucian, 8 vols. Cambridge: Harvard University Press; London: William Heinemann, vol. 6, 1961.

- A True Story. In: Lucian. Cambridge: Harvard University Press; London: William Heinemann, vol. 1, 1961.

MAJESKE, Andrew J. Equity in English Renaissance Literature: Thomas More and Edmund Spenser. Nova York: Routledge, 2006.

MANUEL, Frank E. and MANUEL, Fritzie P. Utopian thought in the western world. Cambridge: The Belknap Press/Harvard University Press, 1997. $7^{\text {a }}$ ed.

MANUEL, Frank. Utopias and utopian thought. Boston: Houghton Mifflin Co, 1966.

McCUTCHEON, Elizabeth. "Denying the Contrary: More's use of Litotes in the Utopia”. In: Moreana, no. 31-32 (Nov 1971): 107-122.

. "Thomas More, Raphael Hythlodaeus, and the Angel Raphael". In: Studies in English Literature, 1500-1900, Vol. 9, No. 1, The English Renaissance (Winter, 1969), pp. 21-38. Disponível em http://www.jstor.org/stable/449931 (acessado em 16/03/2002).

MICHELET, Jules. Histoire de France. Tome huitième: Reforme. Paris: Ernest Flammarion, 1895.

MORE, Thomas. Translations of Lucian. Edição de Craig R Thompson The Complete Works of St. Thomas More, vol. 3, part I, New Haven: Yale University Press, 1974. . Selected Letters. Tradução de Elizabeth F. Rogers. The Yale Editon of the Works of St. Thomas More: Modernized Series. New Haven: Yale University Press, 1961.

. Utopia. Edição de Edward Surtz. London: Yale Unversity Press, 1964. . Utopia. Edição, introdução e notas de Edward Surtz e J. H. Hexter. The Complete Works of St. Thomas More, vol. 4, New Haven and London: Yale University Press, 1993. $3^{\mathrm{a}}$ ed. 
. Utopia. Edição, tradução e introdução de Luigi Firpo. Torino: Strenna Utet, 1971.

. L’Utopie. Edição de Marie Delcourt. Paris: Flammarion, 1987.

. Utopia. Edição, introdução e notas de George Logan e Robert Adams.

Cambridge: Cambridge University Press, 2002.

- Utopia. Edição, tradução e introdução de Dominic Baker-Smith.

London: Penguin, 2012.

- Utopia. Tradução de Márcio Meirelles Gouvêa Jr. São Paulo:

Autêntica, 2017.

MORVS, Thomas. Vtopia ou a melhor forma de governo. Tradução de Aires A. Nascimento. Lisboa: Fundação Calouste Gulbenkian, 3ª ed., 2015.

MUMFORD, Lewis. The story of Utopias. New York: Boni and Liveright Publishers, 1928.

NELSON, Eric. The Greek Tradition in Republican Thought, Cambridge: Cambridge University Press, 2004.

"Utopia through Italian Eyes: Thomas More and the Critics of Civic Humanism". In: Renaissance Quarterly, Vol. 59, No. 4 (Winter 2006), pp. 1029-1057. Disponível em http://www.jstor.org/stable/10.1353/ren.2008.0532 (acessado em 03/06/2016).

NEUMANN, Harry. “On The Platonism of More's 'Utopia”, Social Research, Vol. 33, No. 4, (WINTER 1966), pp. 495-512. Disponível em http://www.jstor.org/stable/40969848 (acessado em 12/12/2015).

OVIDIO, Metamorphoses, London: The Loeb Classical Library, vol. 1, 1971.

PERLETTE, John M. "Of Sites and Parasites: The Centrality of the Marginal Anecdote in book 1 of More's Utopia". In: ELH, Vol. 54, No. 2 (Summer, 1987), pp. 231-252. Disponível em http://www.jstor.org/stable/2873023 (acessado em 07/01/2016). 
PLATÃO. Apologia de Sócrates, precedido de, Eutifron (Sobre a piedade) e, seguido de, Críton (Sobre o dever). Introdução, tradução e notas de André Malta. Porto Alegre: L\&PM, 2010.

. As Leis. Tradução de Carlos Alberto Nunes. Belém: Edufpa, 1980. Coleção Diálogos de Platão, vols. XII e XIII.

. A República. Lisboa: Calouste Gulbenkian, 1987.

. Timeu-Crítias. Trad. Rodolfo Lopes. Coimbra: Centro de Estudos Clássicos e Humanísticos/ Universidade de Coimbra, 2011.

PHÉLIPPEAU, Marie-Claire. "Thomas Morus e a abertura humanista". In: MORUS Renascimento e Utopia, n. 9, 2013.

POCOCK, J. G. A. The Machiavellian Moment: Florentine Political Thought and The Atlantic Republican Tradition. Princenton: Princenton University Press, 1975.

PRÉVOST, André. “L’Utopie: Le Genre Litteraire”. Moreana, no. 31-32 (Nov 1971): $161-168$

. Thomas More et la Crise da Pensée Européenne. Lille: Mame, 1969.

QUINTILIANO, Instituição Oratória. Trad. e notas de Bruno Fregni Bassetto. Campinas: Editora da Unicamp, 2015, 4 vols.

RIBEIRO, Ana Cláudia. “A utopia e a sátira”. In: Morus - Renascimento e Utopia, n. 6, 2009.

- "Traduzindo os recursos sonoros do Livro I da Utopia para o português do Brasil”. In: Cadernos de Tradução, v. 35, n.2, 2015. Disponível em https://periodicos.ufsc.br/index.php/traducao/article/view/2175-

$\underline{7968.2015 v 35 \mathrm{n} 2 \mathrm{p} 211 / 30999}$ (acessado em 19/10/2016).

RIVOLETTI, Christian, “Scienza, sapere umanistico e tecnica nell'Utopia di Thomas Morus", Morus - Renascimento e Utopia, n. 4, 2007. 
ROBBIO, Matías Sebastián Fernandez, "La Travessia de Yambulo per las Islas del Sol", Morus - Renascimento e Utopia, n. 7, 2010.

ROTTERDAM, Erasmo de. Diálogo ciceroniano. São Paulo: Unesp, 2013. . Elogio da loucura. Porto Alegre: L\&PM, 2003. . Elogio da loucura. Org. e trad. Elaine C. Sartorelli. São

Paulo: Hedra, 2013.

SCHWARTZ, Sandra. "Os utopianos são epicuristas? A recepção da ética epicurista na Utopia de Thomas Morus". In: Morus - Utopia e Renascimento, 9, 2013.

SEEBOHM, Frederic. The Oxford Reformers: John Colet, Erasmus, and Thomas More. London: Longmans, Geen and Co, 1869.

SHIBATA, Ricardo Hiroyuki. "A cidade perfeita e a ficção do conselho: o Livro I da Utopia de Morus". Morus: Utopia e Renascimento, n 1, 2004, p. 65-82.

SIDNEY, Philip Sir \& PERCY, Shelley B. Defesas da Poesia. Ensaio, tradução e notas Enid Abreu Dobranszky. São Paulo: Iluminuras, 2002.

SKINNER, Quentin. As Fundações do Pensamento Político Moderno. São Paulo: Editora Moderna, 2006. . "Review Article: More’s Utopia”. Past and Present, no 38 (1967): 153-68. Disponível em http://www.jstor.org/stable/649752 (acessado em 16/03/2012). . Visions of Politics. Cambridge: Cambridge University Press. 2014. 3 vols.

SURTZ, Edward. "Epicurus in Utopia" ELH: a journal of English Literary History, Vol. 16, No. 2 (Jun., 1949), pp. 89-103. Disponível em http://www.jstor.org/stable/2871512 (acessado em 17/03/2012). .Interpretations of Utopia". Catholic Historical Review, 38 (1952):156-74. Disponível em http://www.jstor.org/stable/25015417 (acessado em 17/03/2012). 
. "The Defense of Pleasure in More's 'Utopia'”. Studies in Philology, Vol. 46, No. 2 (Apr., 1949), pp. 99-112. http://www.jstor.org/stable/4172882 (acessado em 17/03/2012).

SYLVESTER, Richard S. "Si Hythlodaeo Credimus": Vision and Revision in Thomas More's Utopia", Soundings, vol. 51, no. 3 (Fall, 1968), 272-289. http://www.jstor.org/stable/41177723 (acessado em 02/08/2016).

TODD, M. Christian humanism and the puritan social order. Cambridge: Cambridge University Press, 1987.

TRACY, J. Erasmus of the Low Countries. Berkeley:University of California Press, 1997.

TREVOR-ROPER, Hugh. "The Intellectual World of Sir Thomas More". The American Scholar, Vol. 48, No. 1 (Winter 1979), pp. 19-32. Disponível em http://www.jstor.org/stable/41210475 (acessado em 02/02/2016).

TROUSSON, Raymond. Voyages aux pays de nulle part. Bruxelles: éditions de l’université de Bruxelles, 1975.

VERNANT, Jean-Pierre. Mythe et pensée chez les grecs. In: . Oueuvres. Paris : Éditions du Seuil, 2007, vol.1. . Les ruses de l'intelligence : la mètis des grecs. In:

Oueuvres. Paris : Éditions du Seuil, 2007, vol.2.

. L'Universe, les dieux e les hommes. In: . Oueuvres.

Paris : Éditions du Seuil, 2007, vol.2.

WHITE, Thomas I. "Aristotle and Utopia", Renaissance Quarterly, Vol. 29, No. 4, (Winter, 1976) pp. 635-675. Disponível em http://www.jstor.org/stable/2860035 (acessado em 16/03/2012).

"Pride and The Public Good: Thomas More's Use of Plato in Utopia" Journal of History of Philosophy, Volume 20, Number 4 (October, 1982), pp. 329-354. Disponível em https://muse.jhu.edu/article/227104 (acessado em 31/05/2016). 
WINIARCZY, Marek. The 'Sacred History' of Euhemerus of Messene, Berlin/Boston: De Gruyter, 2013.

WOODEN, Warren W. "Anti-Scholastic Satire in Sir Thomas More's Utopia". The Sixteenth Century Journal, Vol. 8, No. 2, Humanism in the Early Sixteenth Century (Jul., 1977), pp. 29-45. http://www.jstor.org/stable/2539437 (acessado em 05/04/2012).

WOLFF, Francis. Aristóteles e a política. Tradução de Thereza Christina Ferreira Stummer e Lygia Araújo Watanabe. São Paulo: Discurso Editorial, 1999.

WOOLFSON, J. Reassessing Tudor Humanism. New York: Palgrave Macmillan, 2002.

WOOTTON, David. "Friendship Portrayed: A New Account of Utopia." History Workshop Journal 45 (1998): 29-47.

YORAN, H. Between utopia and dystopia: Erasmus, Thomas More, and the humanist Republic of Letters. Lanham: Lexington Books, 2010.

ZINGANO, M. (org.). Sobre a Ética nicomaqueia de Aristóteles: textos selecionados. São Paulo: Odysseus, 2010. 